Portland State University

PDXScholar

6-1965

\title{
Development of a Tool to Measure Applicability of the General Systems Theory to Generic Social Work
}

\author{
Richard L. DeCristoforo \\ Portland State University \\ Justus H.G. Freimund \\ Portland State University \\ Lewis G. Hahn \\ Portland State University \\ Herbert J. Hansen \\ Portland State University \\ Arne O. Henifin \\ Portland State University
}

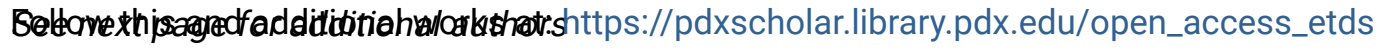

Part of the Social Work Commons

Let us know how access to this document benefits you.

\section{Recommended Citation}

DeCristoforo, Richard L.; Freimund, Justus H.G.; Hahn, Lewis G.; Hansen, Herbert J.; Henifin, Arne O.; Kalogeratos, June Hohensee; Kim, Hyung Bok; Peterson, Richard S.; Smith, Louise; and Winchester, Lewis L. Sr., "Development of a Tool to Measure Applicability of the General Systems Theory to Generic Social Work" (1965). Dissertations and Theses. Paper 351.

https://doi.org/10.15760/etd.351

This Thesis is brought to you for free and open access. It has been accepted for inclusion in Dissertations and Theses by an authorized administrator of PDXScholar. Please contact us if we can make this document more accessible: pdxscholar@pdx.edu. 


\section{Author}

Richard L. DeCristoforo, Justus H.G. Freimund, Lewis G. Hahn, Herbert J. Hansen, Arne O. Henifin, June Hohensee Kalogeratos, Hyung Bok Kim, Richard S. Peterson, Louise Smith, and Lewis L. Winchester Sr. 


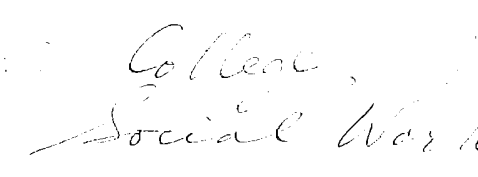

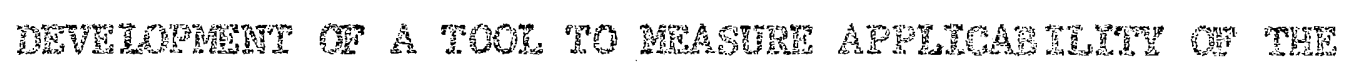

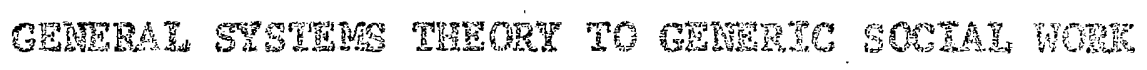

\author{
by \\ Rehard to Dectistororo

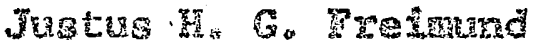 \\ Lew? G. Hahn \\ Heabert $J_{\text {. Hasen }}$ \\ Arme 0. Hentrin \\ June Hohenses palogeracos \\ Hyung Bor mex \\ Rehare S. Peterson \\ Loutse Salith

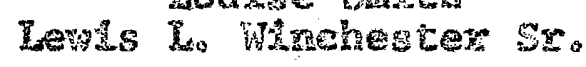

A GROUP RESERER PROTER

Presenced to the Bchool of Somat Work

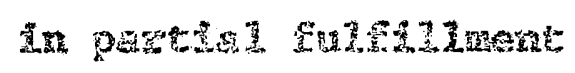

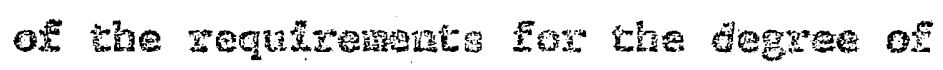

Master of 500 ara

Juse 385 


\section{ABSTRACT}

The goal of this project was to test the applicabilitig of the General Systems Theory to the traditionally held concept of generic social work. If an applicability existed, a direct survey of the field would be feasible. This could lead to the development of a genexal or a core conceptualination of social work practice.

Ceneral Systems Theory was extended to include the properties of the open organismic human group system. There were twanty-one categories at this level of abstraction. Internal consistency of the General Systems Theory model was tested and related to social work treatmont concepts. To do this, 427 concepts which describe socjal work actions were isolated from traditional social work litcerature and its thres methods of practice. The seliability of classitying these action concepts into the twenty-one Ceneral Systems Theory categories was tested.

All of the action concepts could be classified into the Ceneral Systems Theory categories. None of the action concepts class clasfied into the twenty-second, residus. category. Non-parametric statistical tests were used to measure raliability. Rellability sras found to be low. The low reliability wes inversels related to training and was not related to other factors tested. Crouping the action concepts in a number of different weys did not significantly change the low reliability. The social work action concepts were found to be vague, not discrete, and of uncertain levels of abstraction. Specific, concrete definition of any given action concept was found to be difficult.

Within the limits of this study, it was suggested that actual social work practice would have to be reconceptualized in more accurate terms before General Systems Theory and social work practice could be reconciled. 


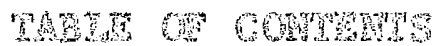

GRAP

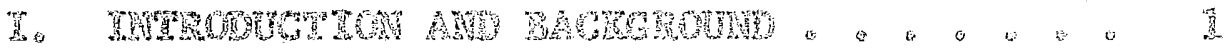

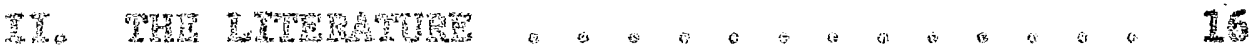

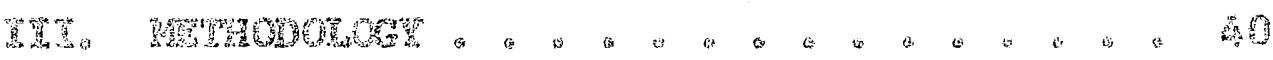

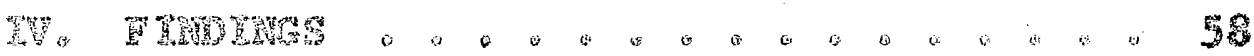

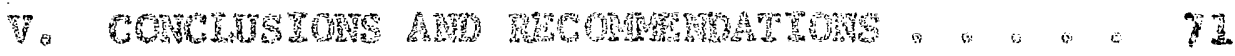

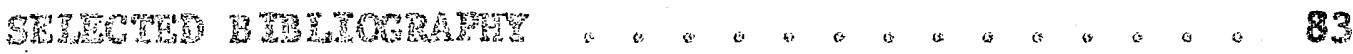

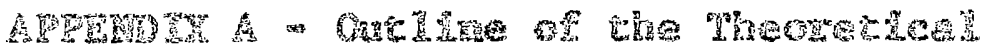

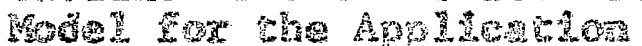

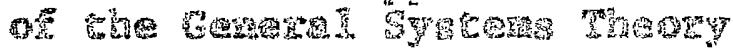

to Soctid Wores

A

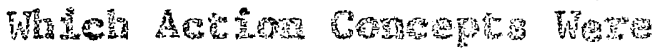

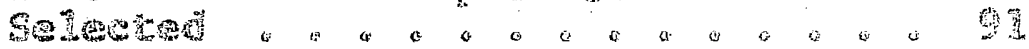

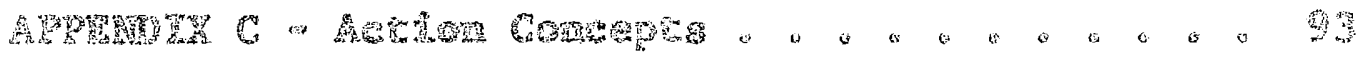

APrW

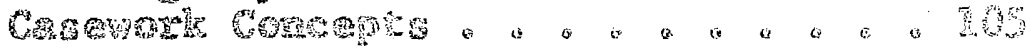

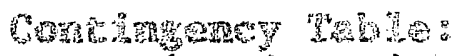

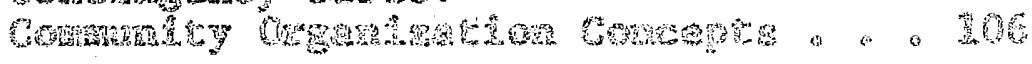

Gonding

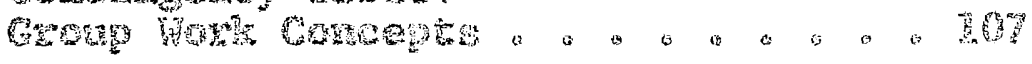

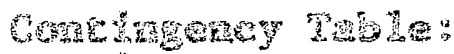

Whoth 


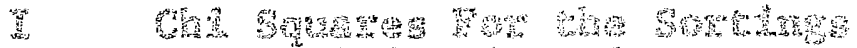

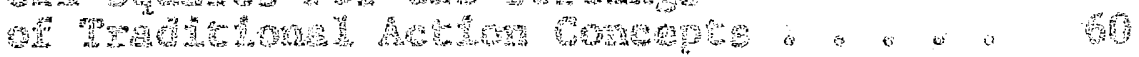

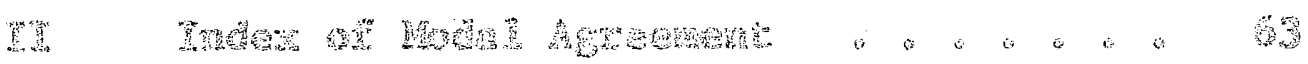




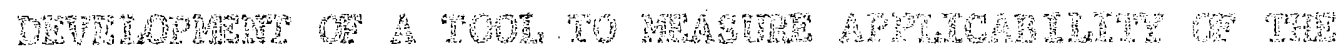

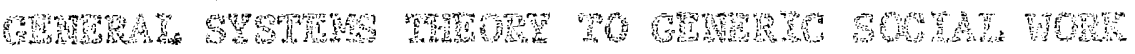

\section{WHFER}

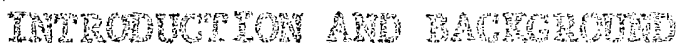

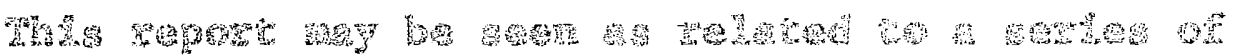

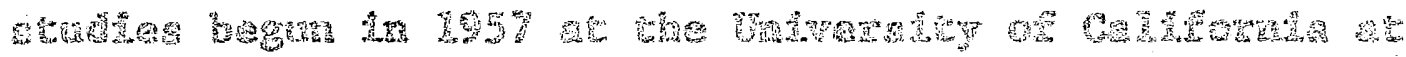

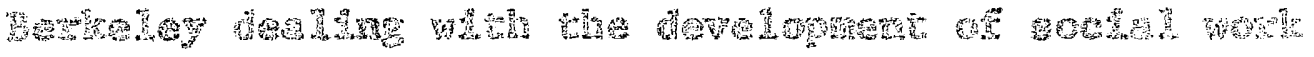

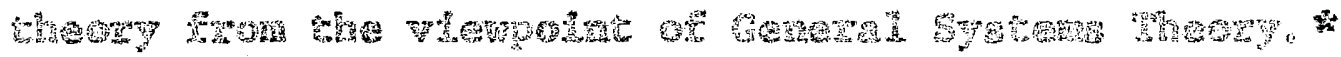

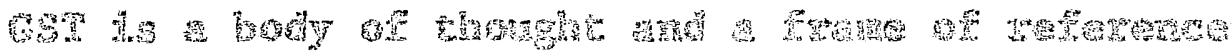

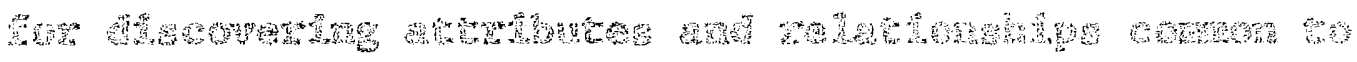

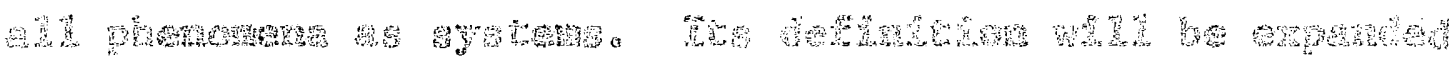

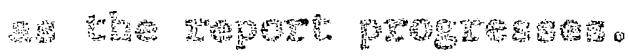

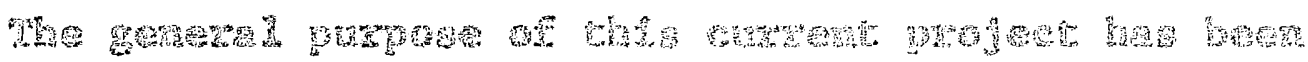

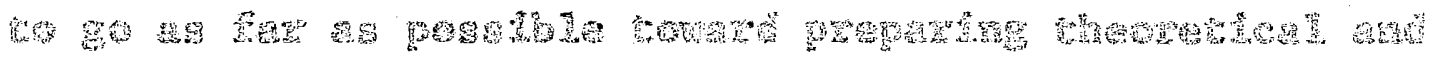

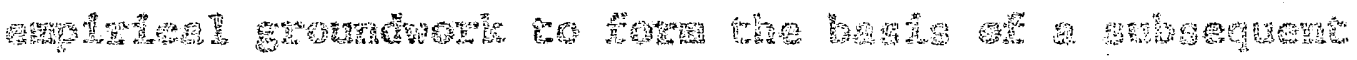

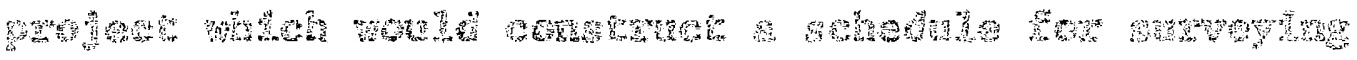

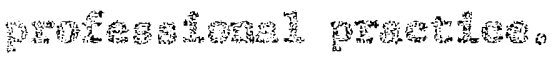

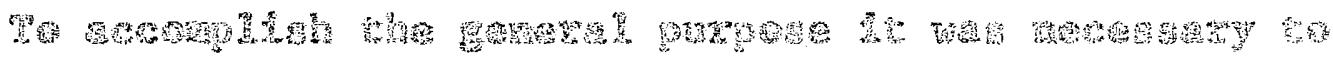

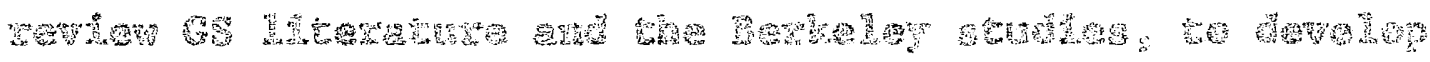

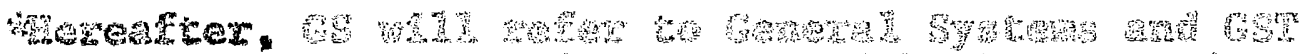

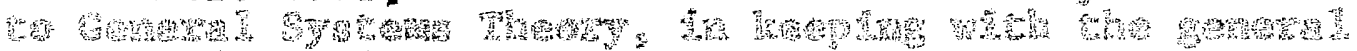

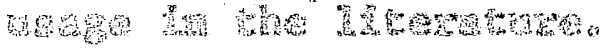




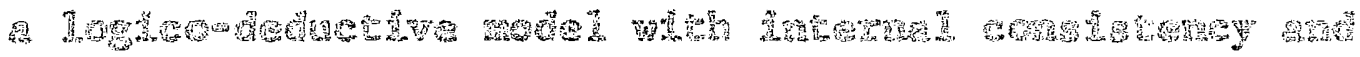

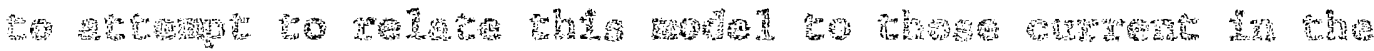

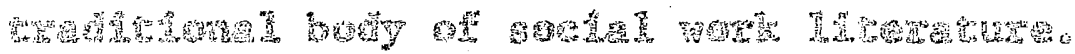

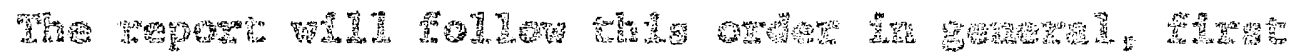

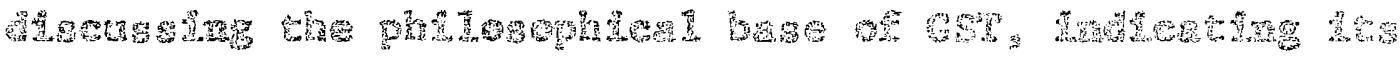

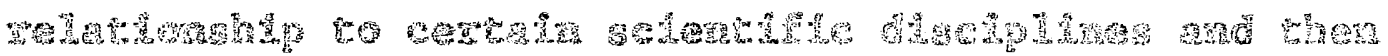

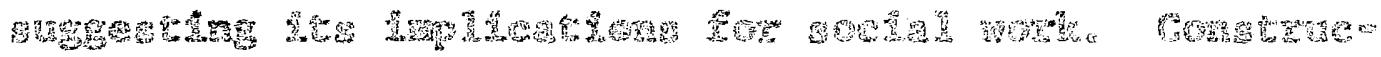

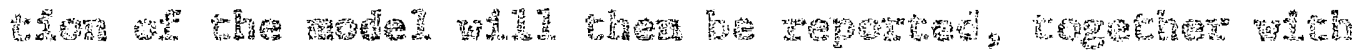

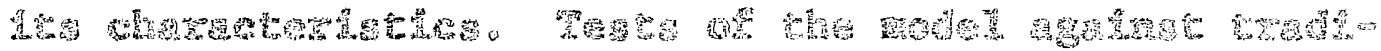

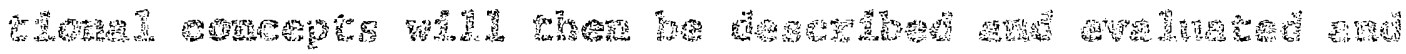

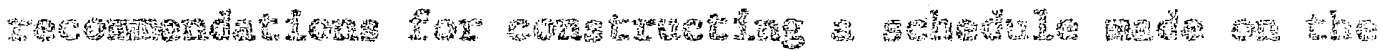

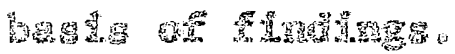

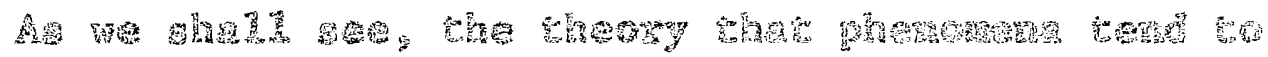

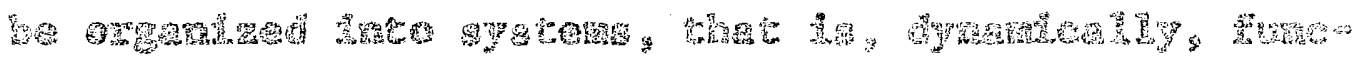

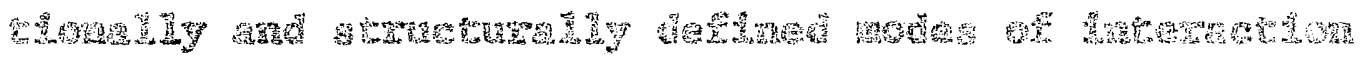

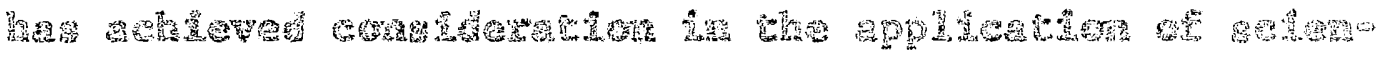

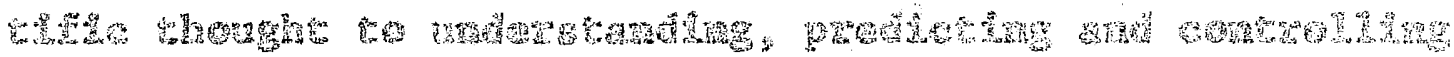
3

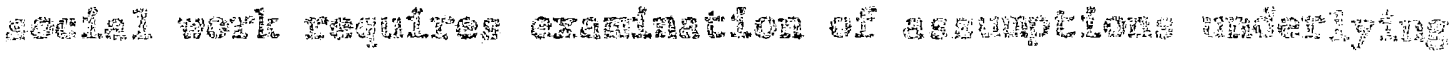

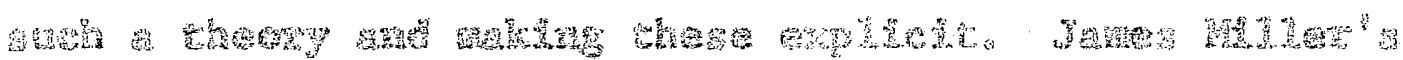

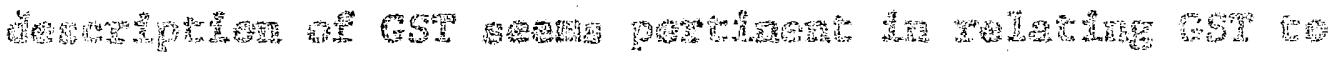

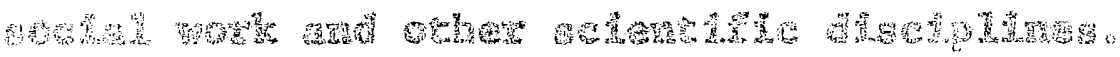

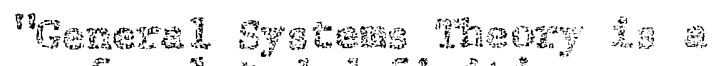

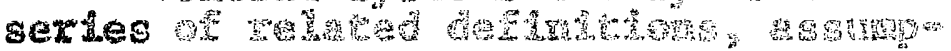

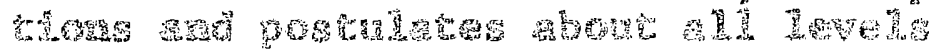

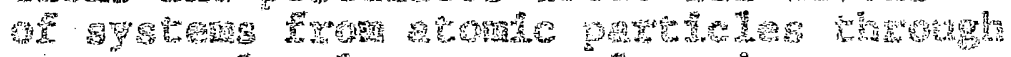

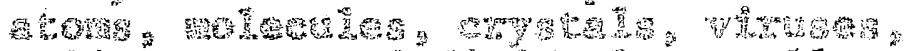

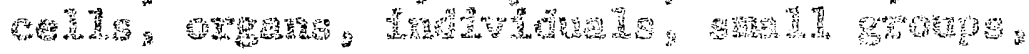




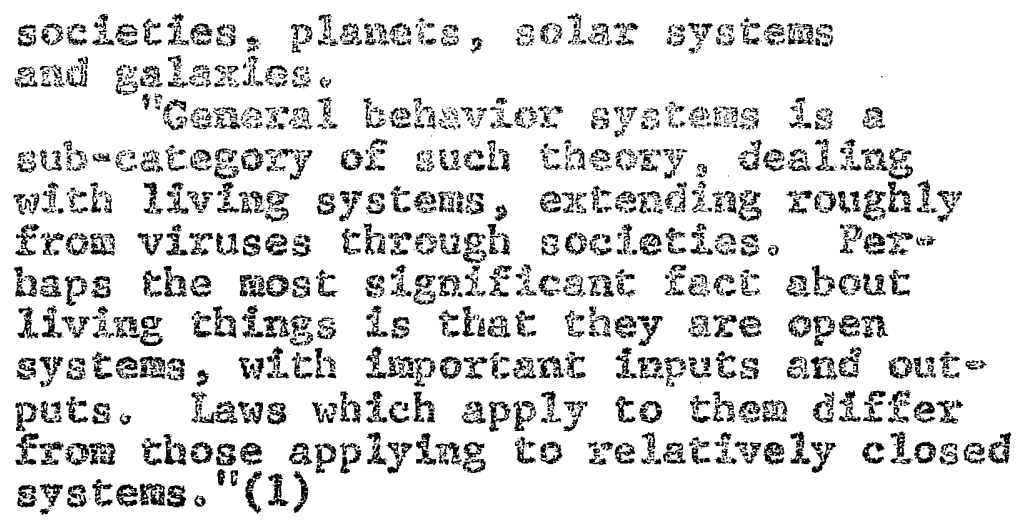

It is ackandedged that by endorsing a partecutar

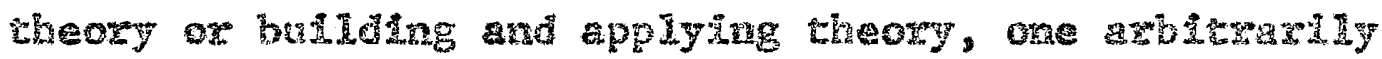

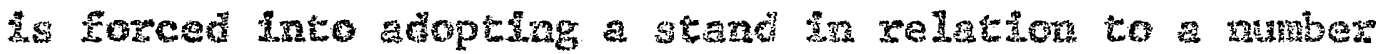

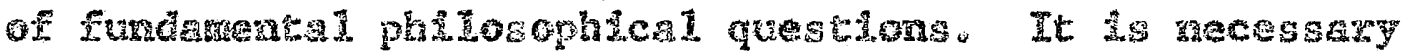

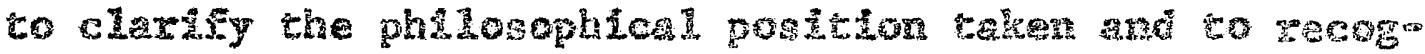

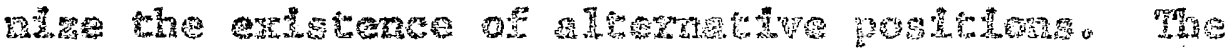

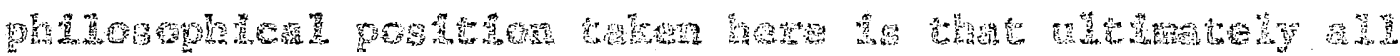

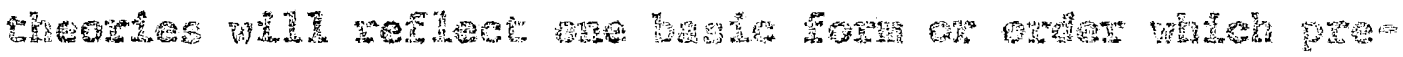

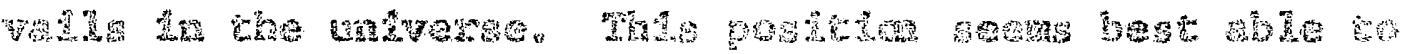

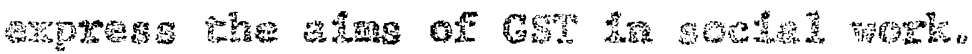

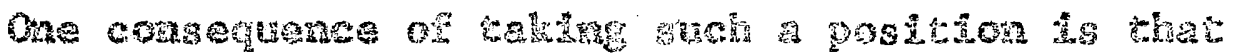

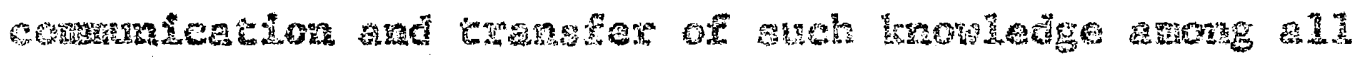

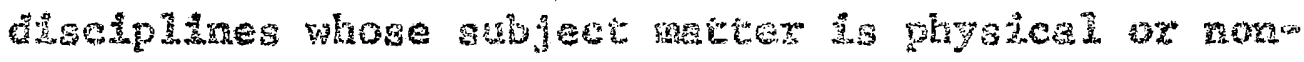

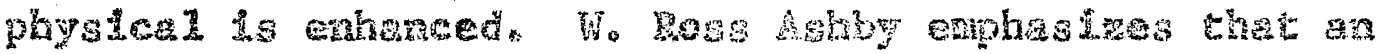

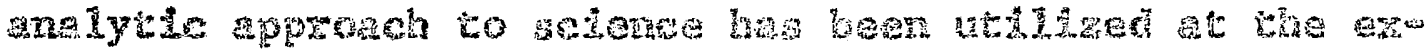

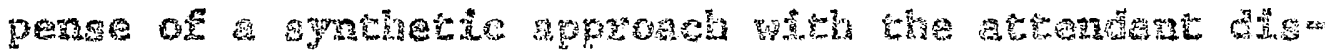

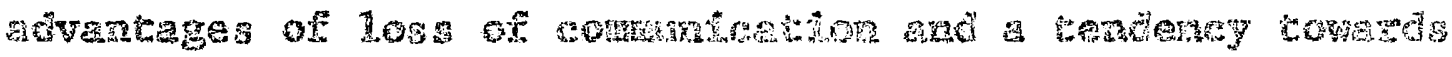

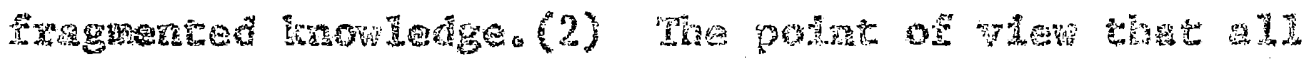

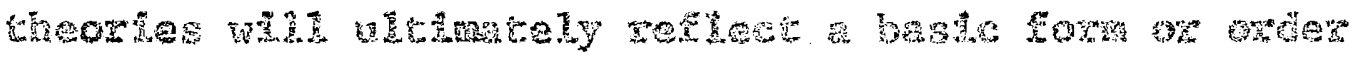




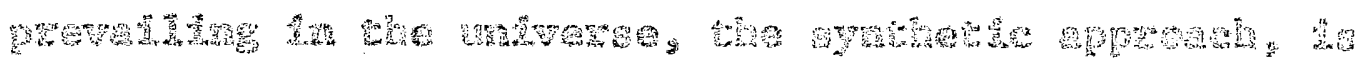

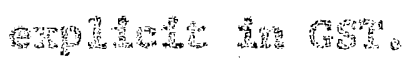

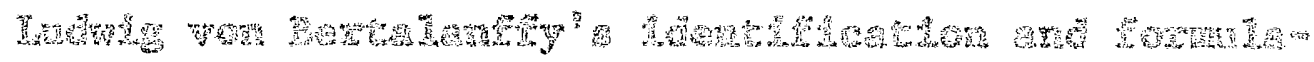

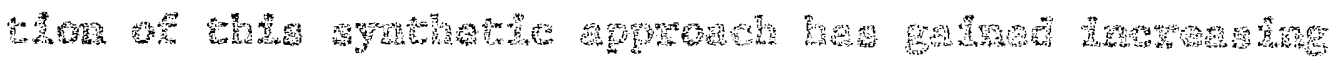

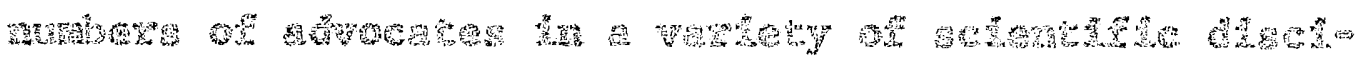

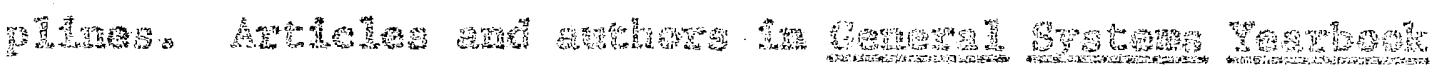

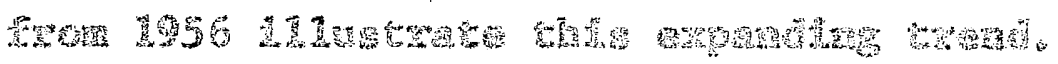

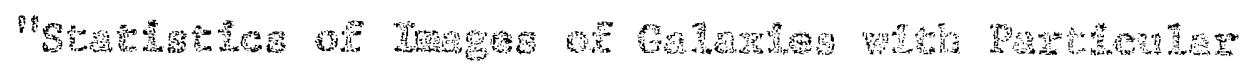

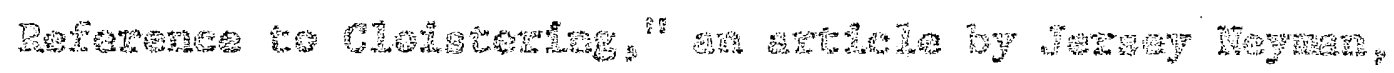

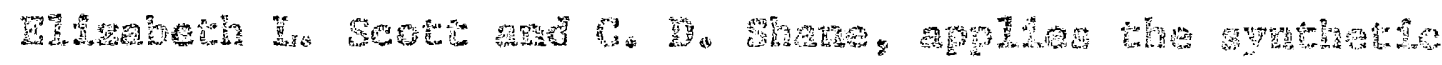

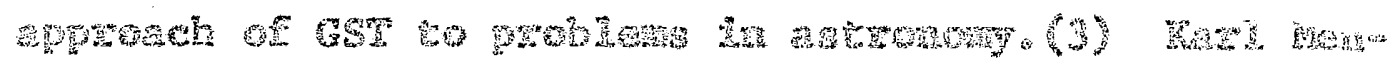

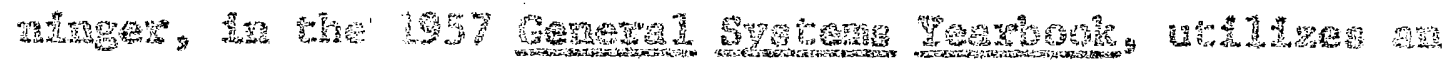

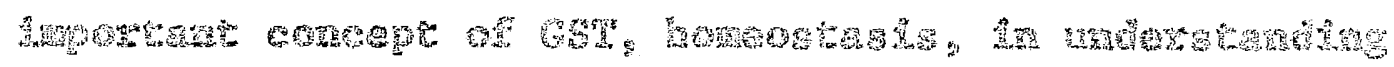

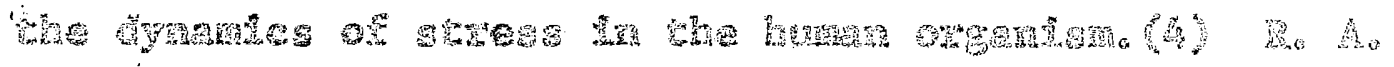

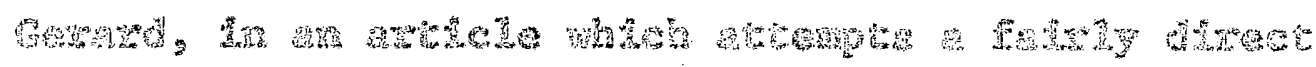

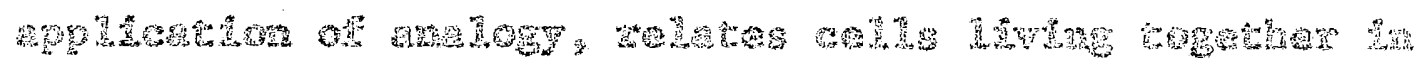

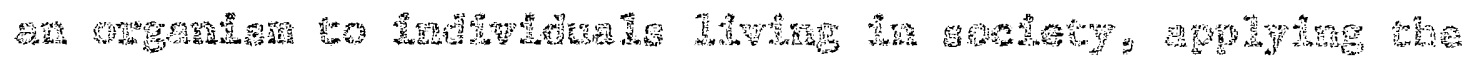
a

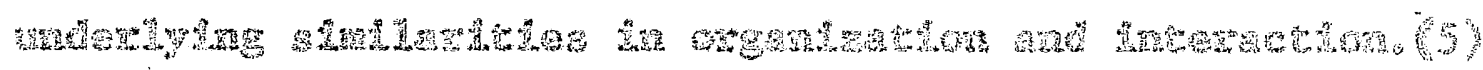

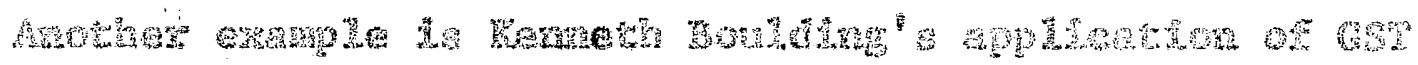

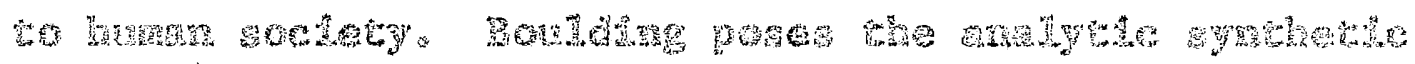

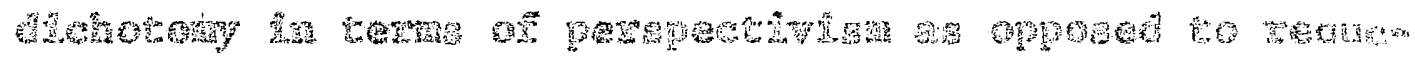

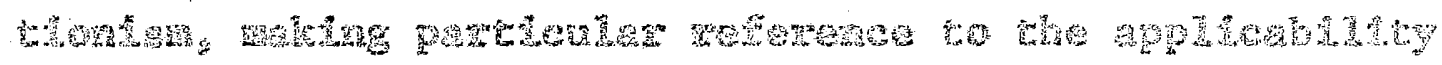

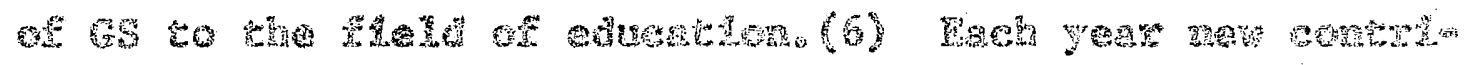

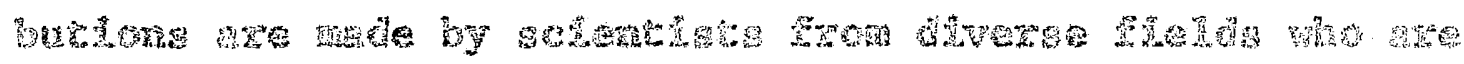

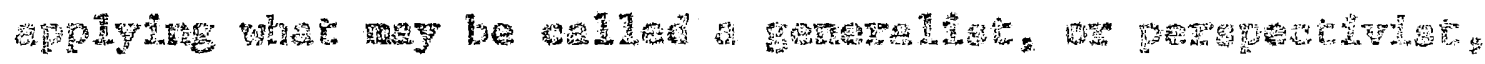




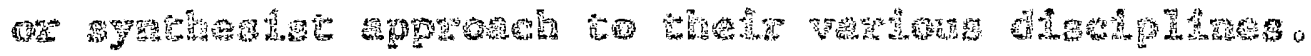

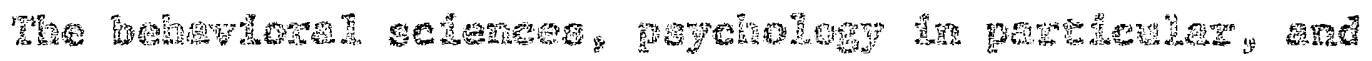

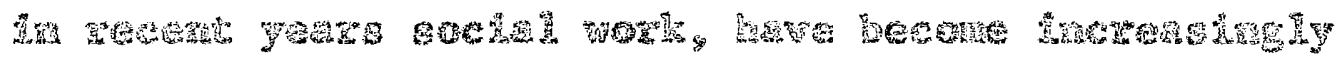

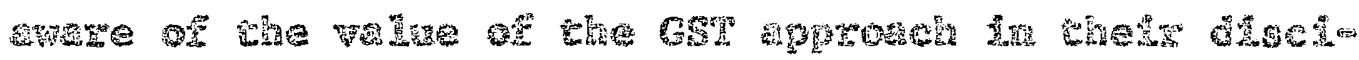
pines.

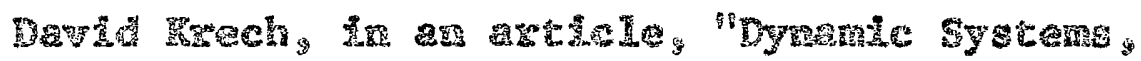

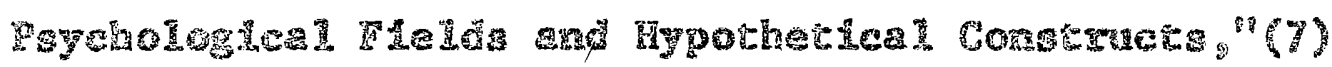

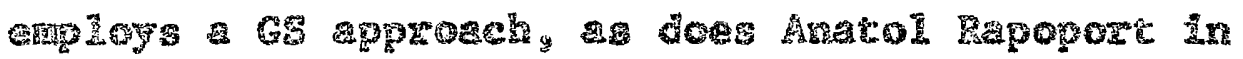

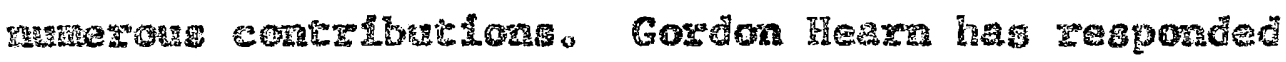
to the 65 approal and has endeawored to devenup a

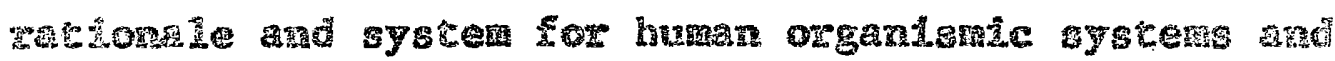

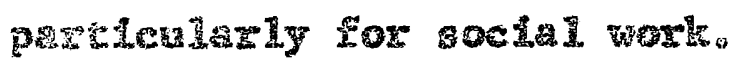

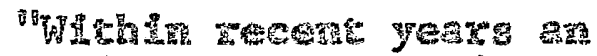

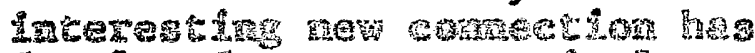

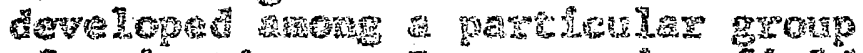

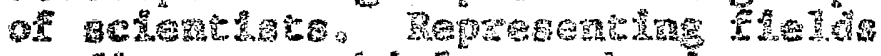

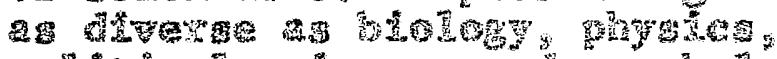

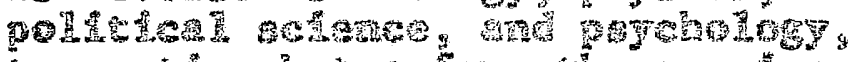

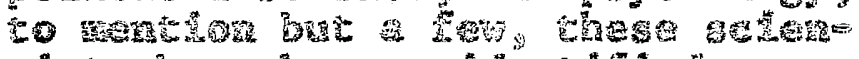

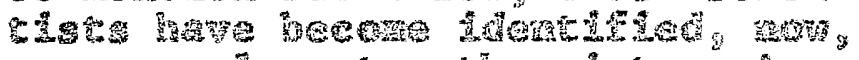

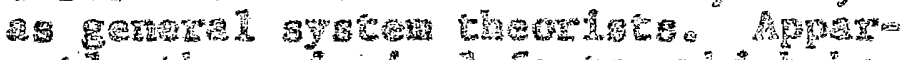

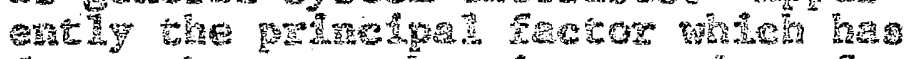

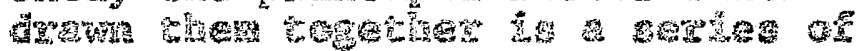

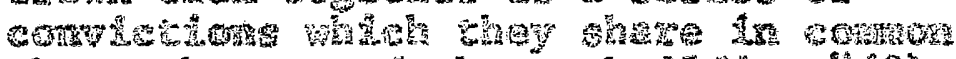

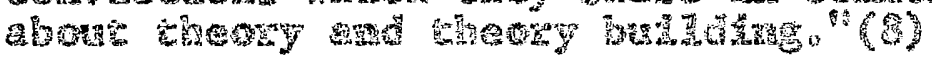

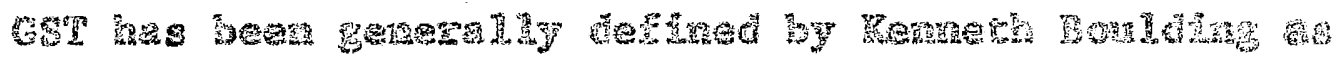

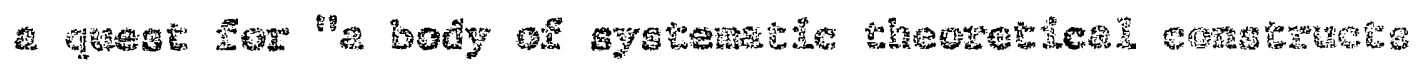
why

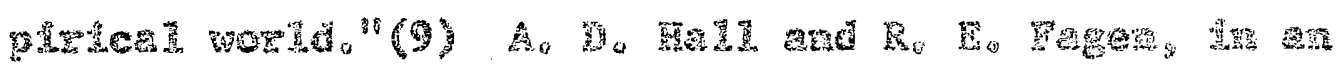
aresa

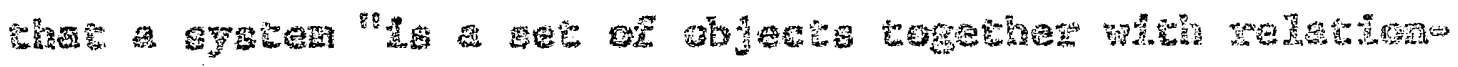

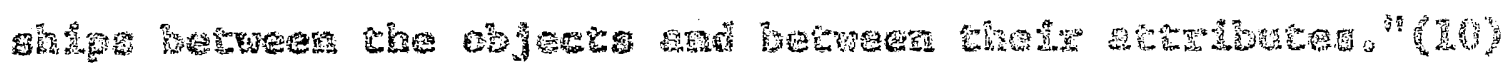


虫被

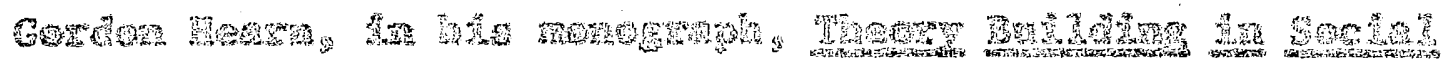

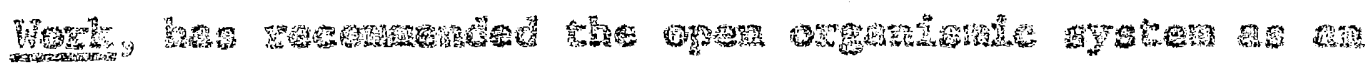

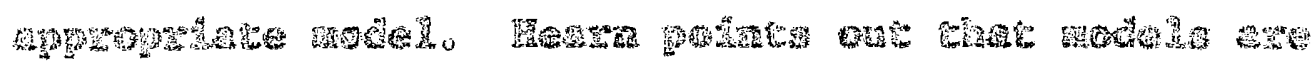

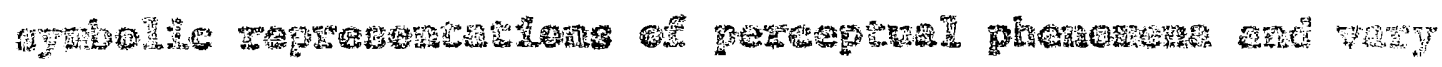

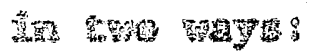

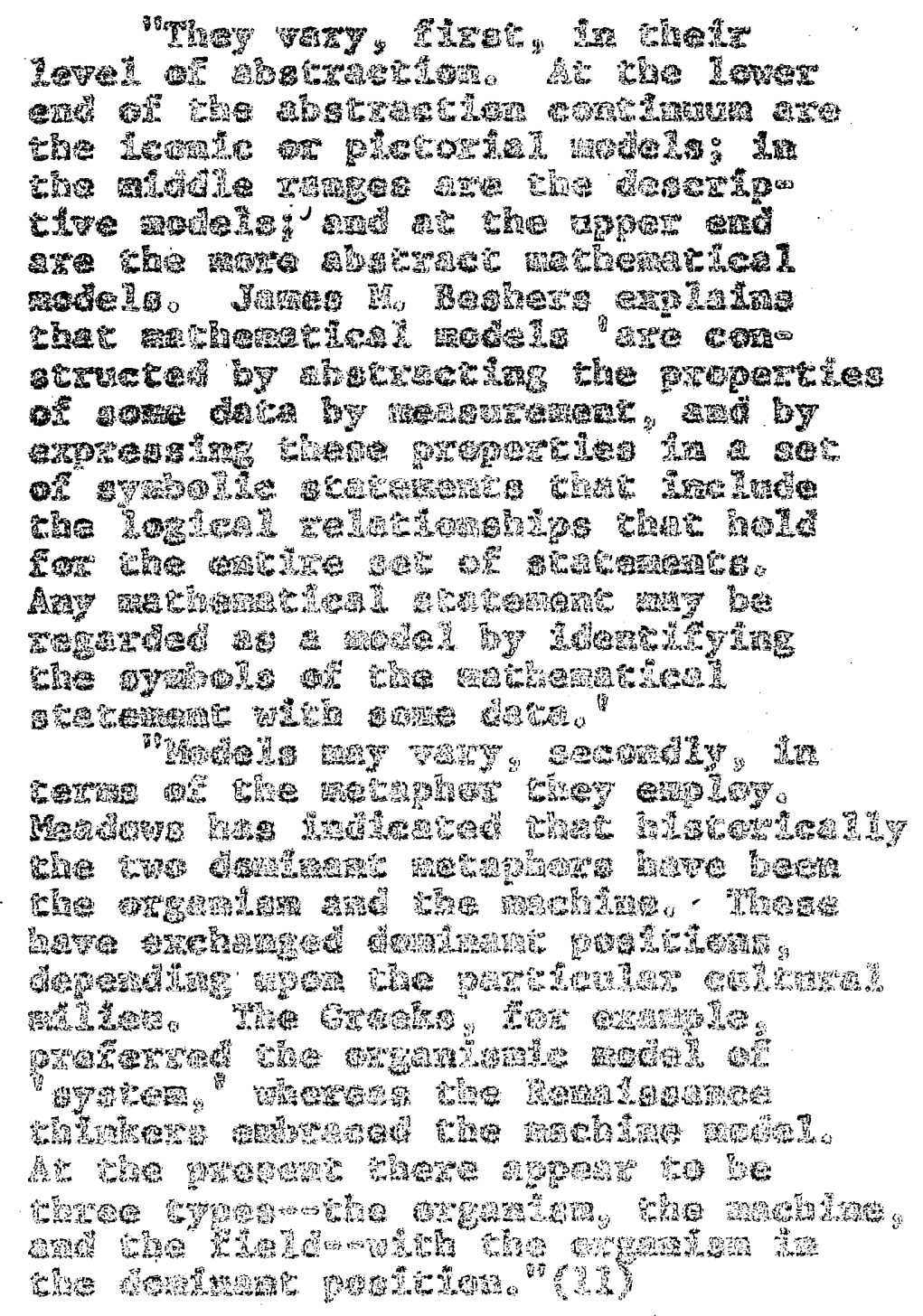

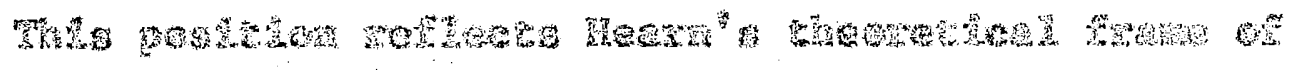
20. why 
Q

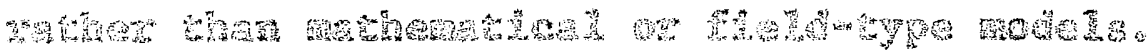

"HF

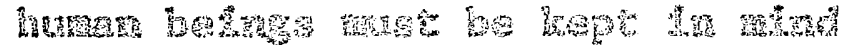

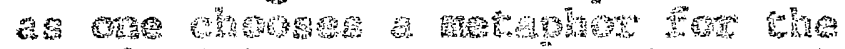

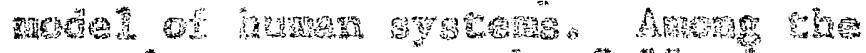

a

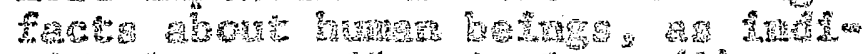

7.

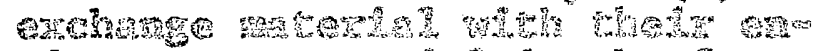

19

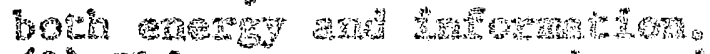

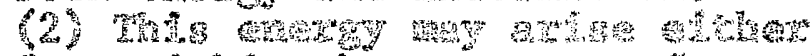

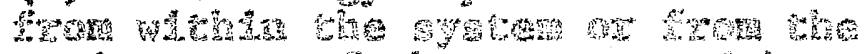

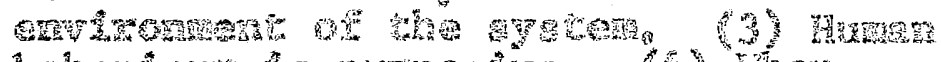

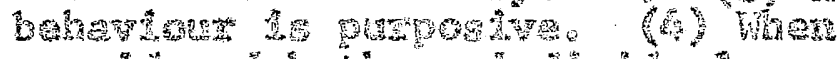

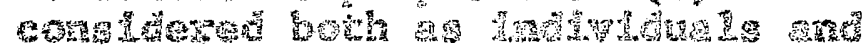

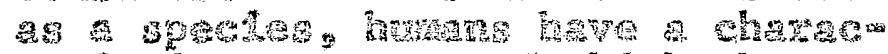

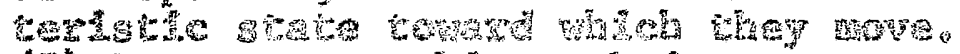

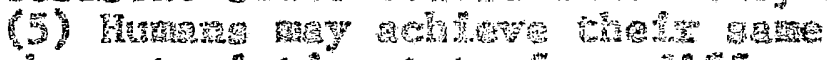

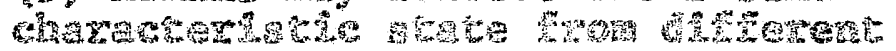

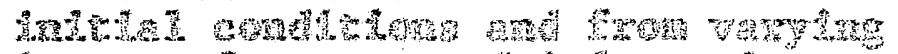

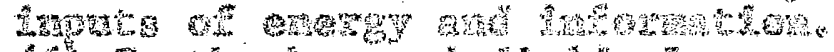

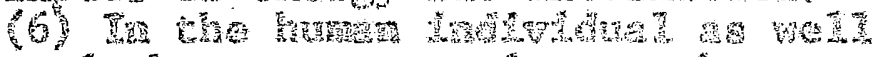

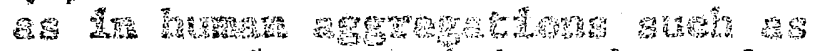

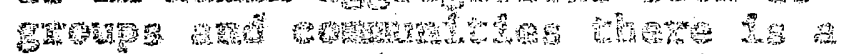

by

Furet

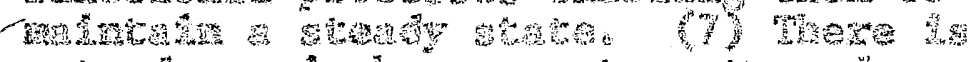

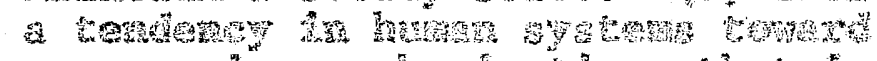

Fris

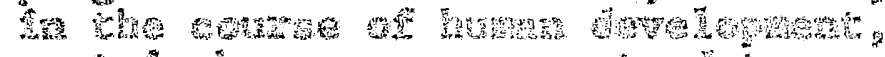

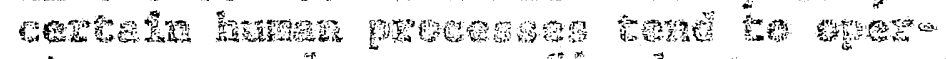

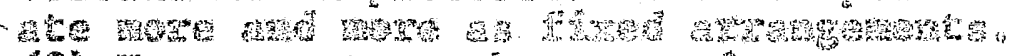

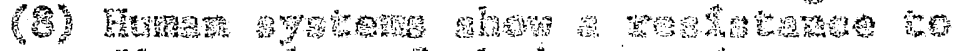

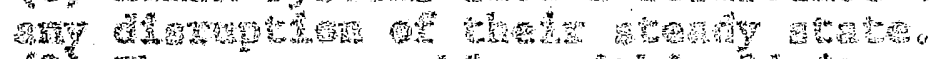

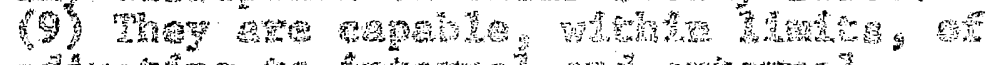

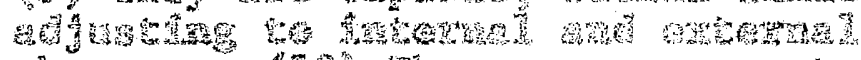

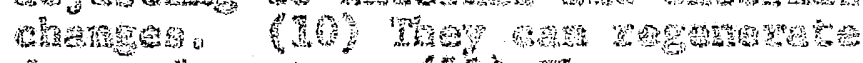

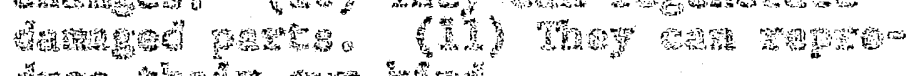

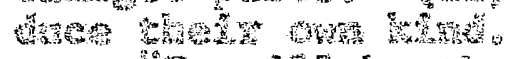

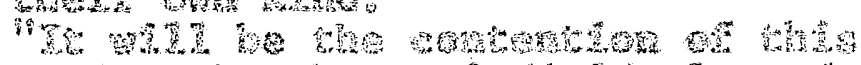

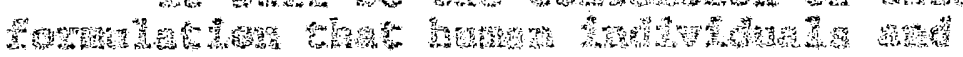

HoN

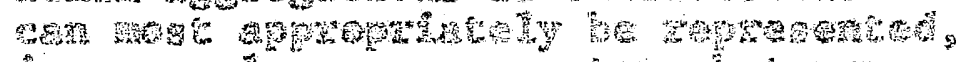

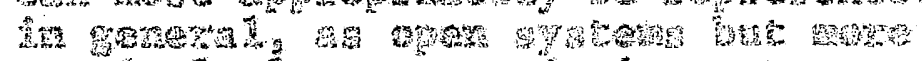

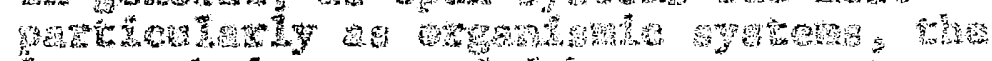

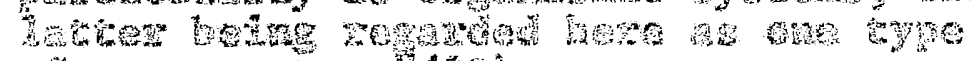
nte rase wy 


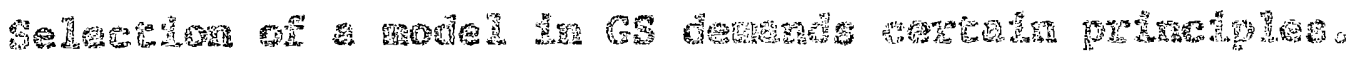
Fing

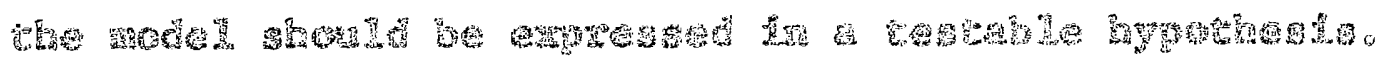

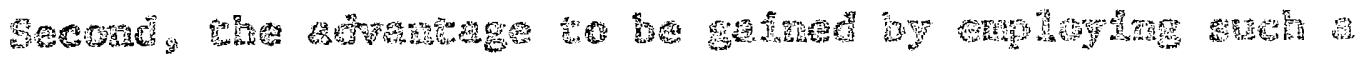

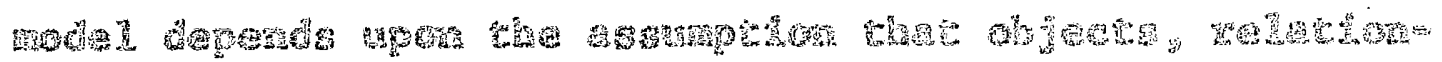

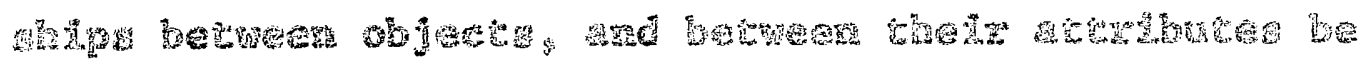

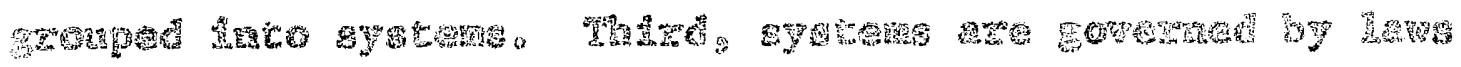

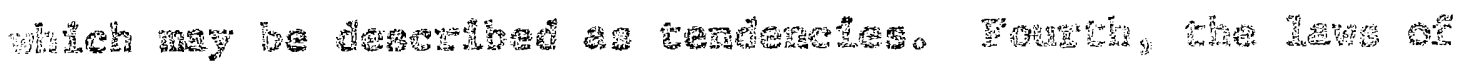

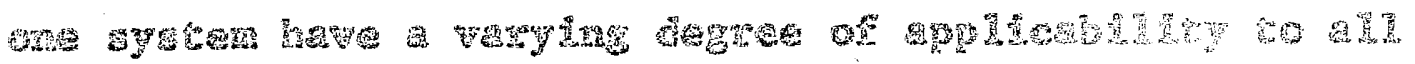

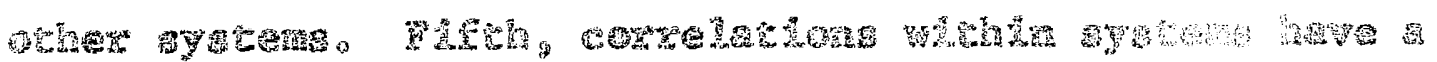

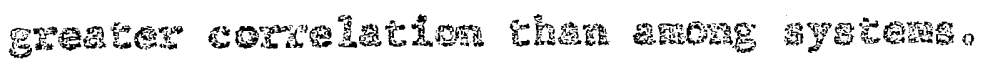

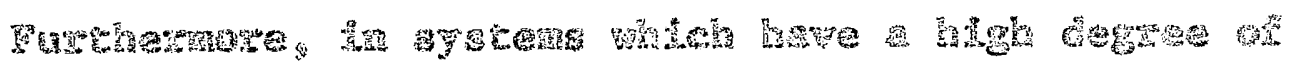

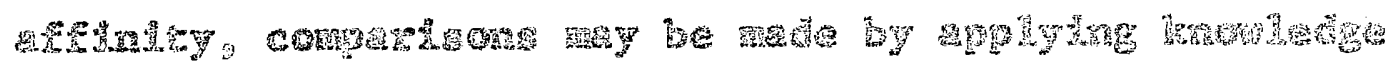

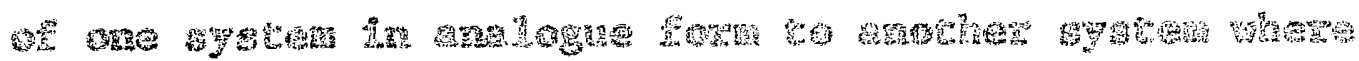

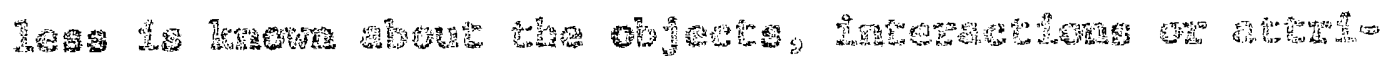

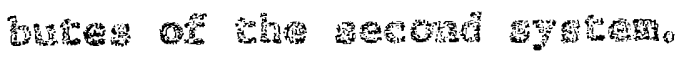

ar w

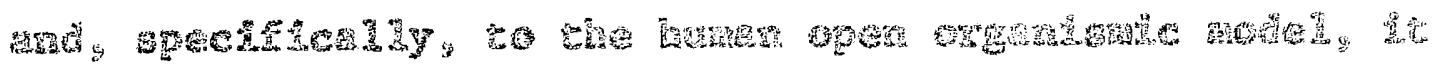

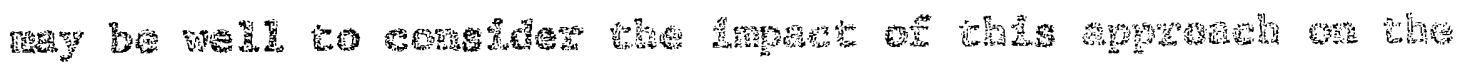

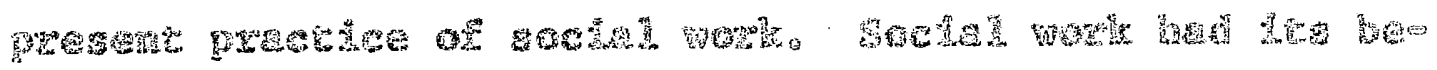

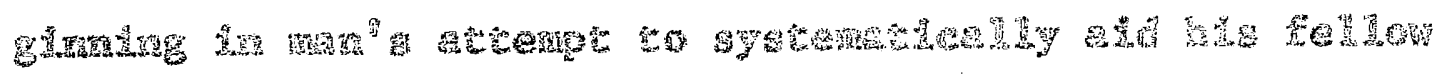

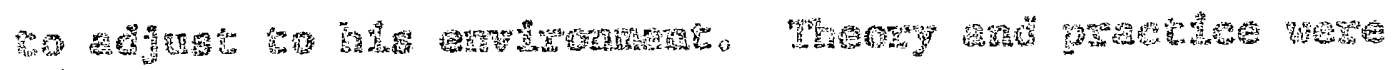

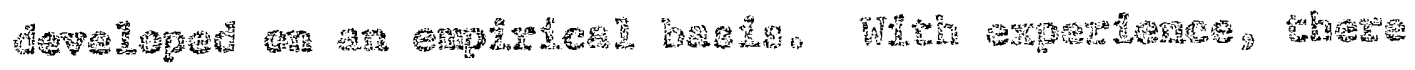

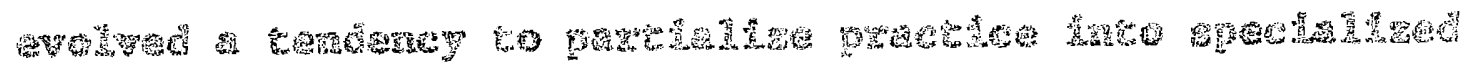

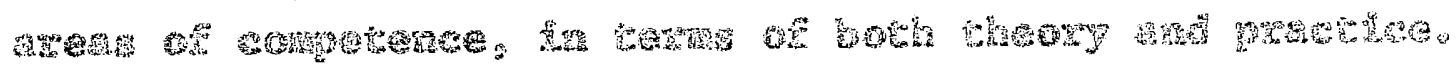

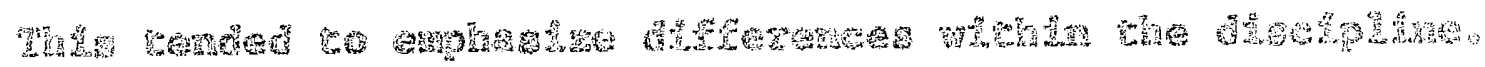




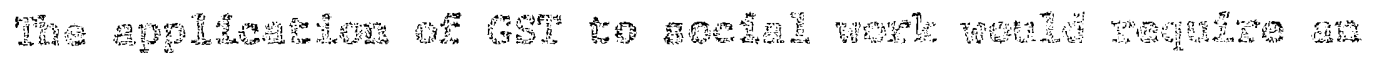

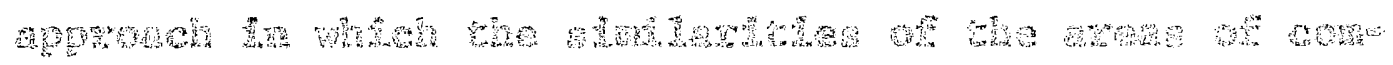

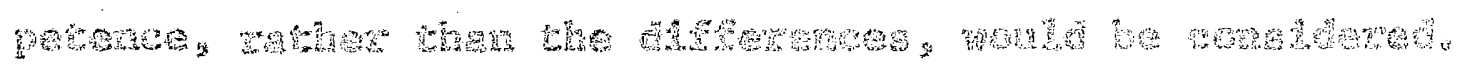

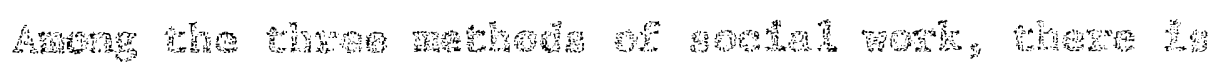

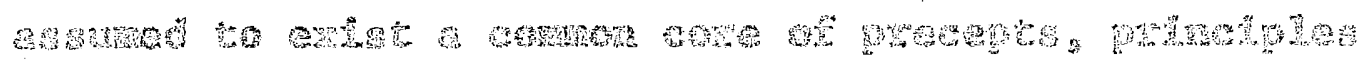

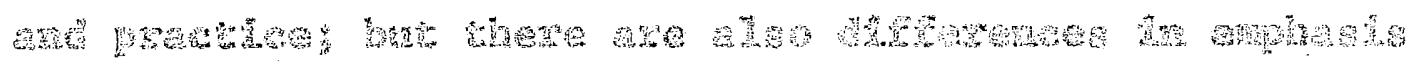

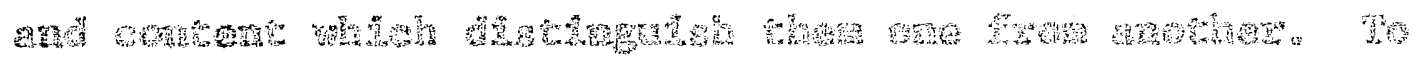

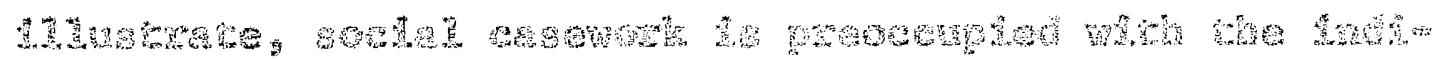

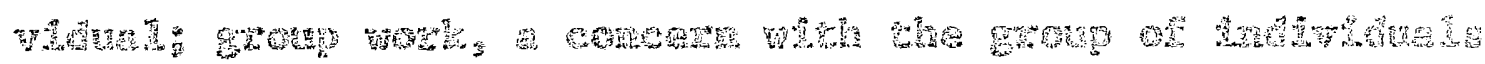

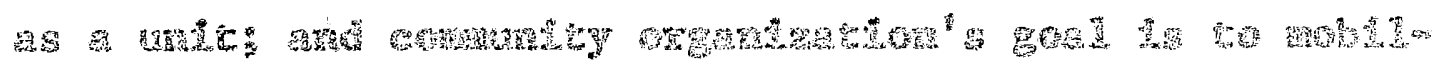

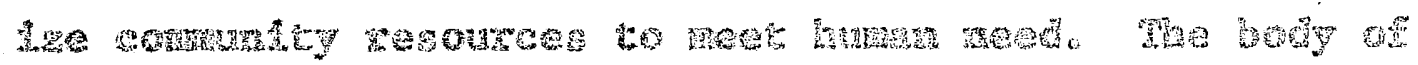

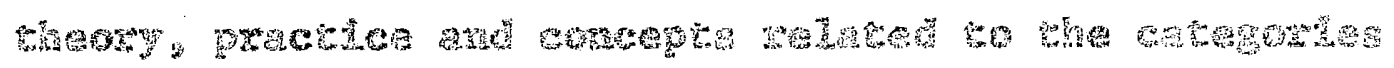

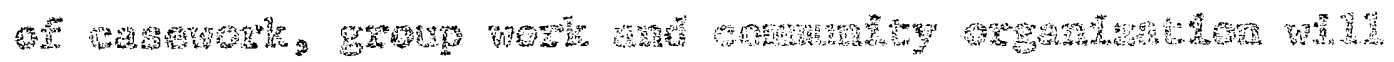

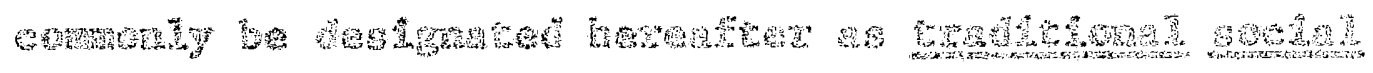
Woy Ty

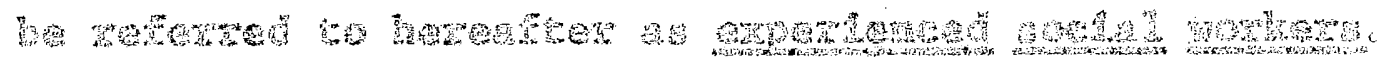

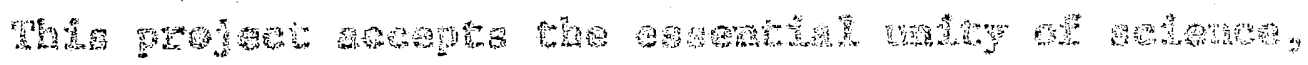

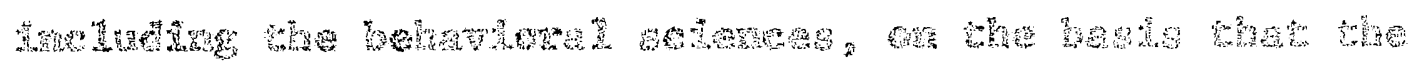

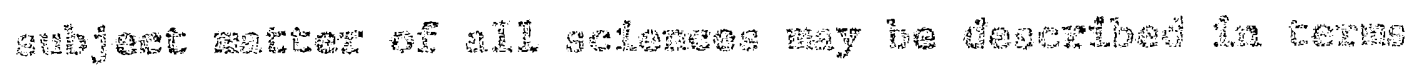

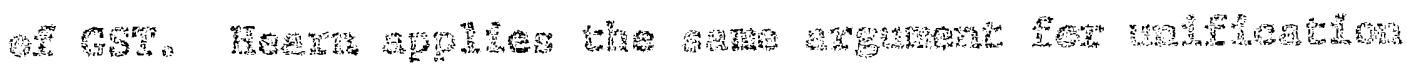

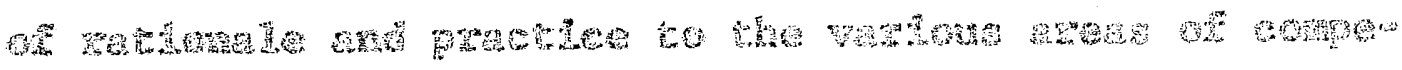

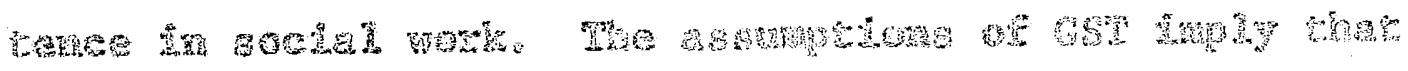

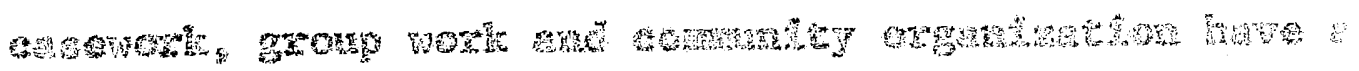

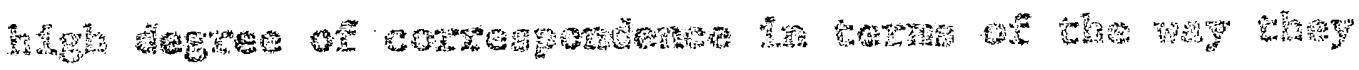

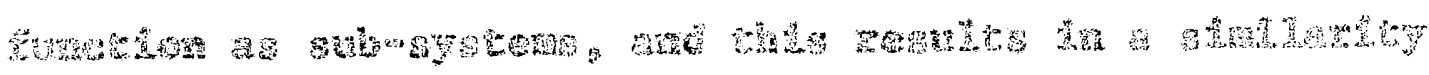

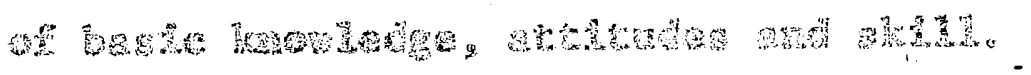




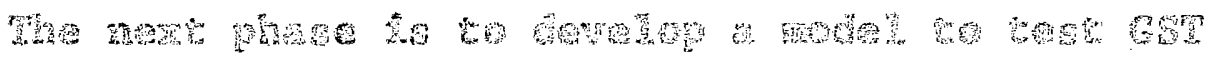

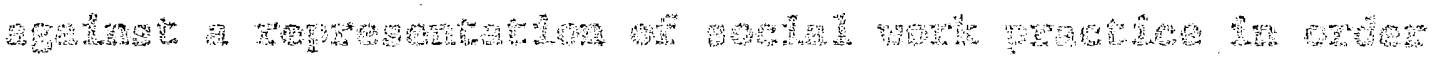

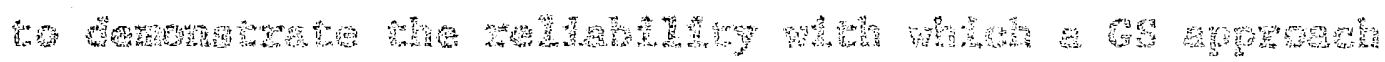

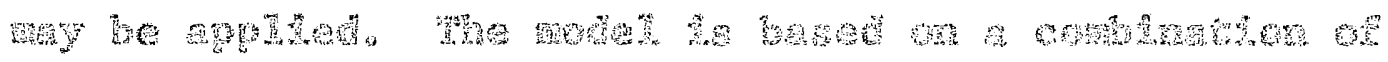

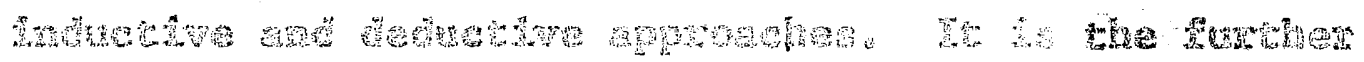

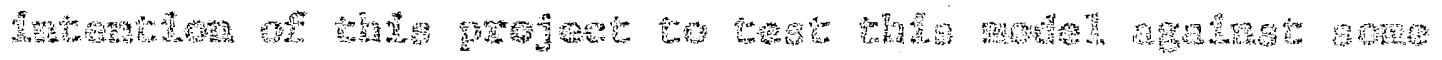

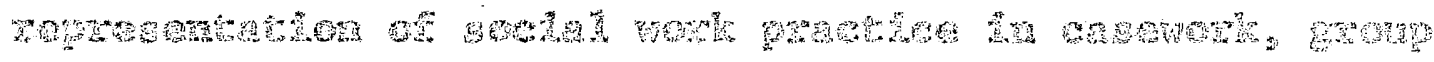

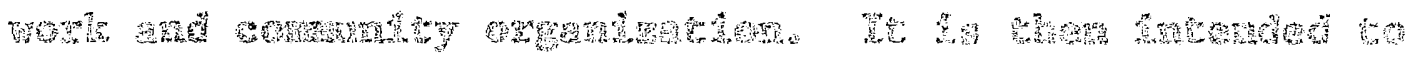

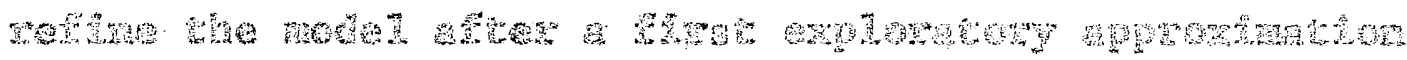

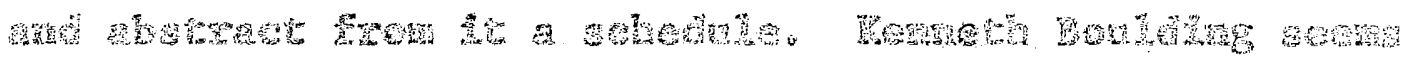

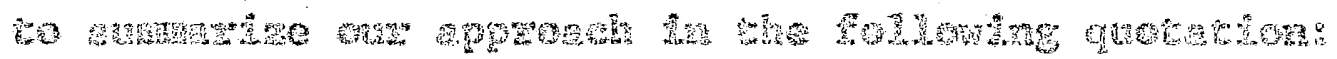

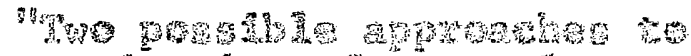

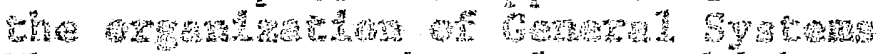

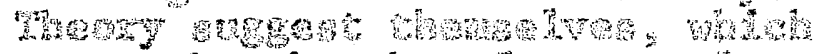

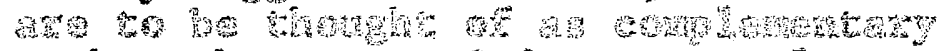

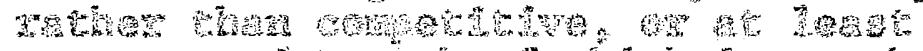

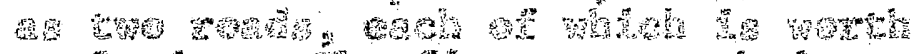

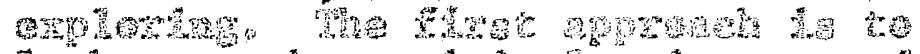
音

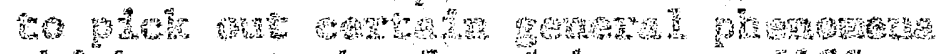

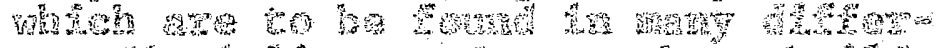

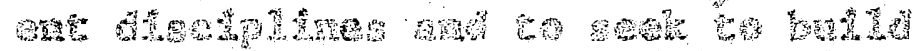

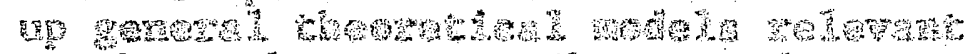

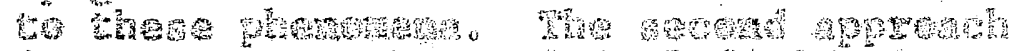

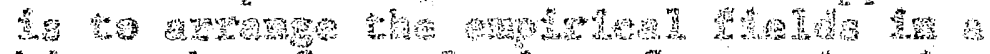

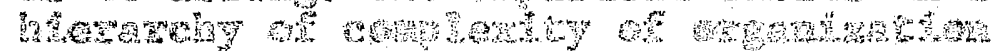

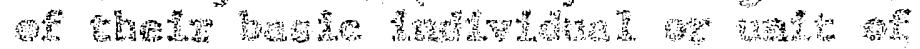

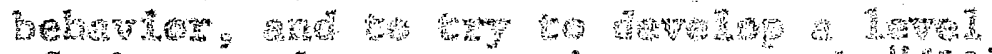

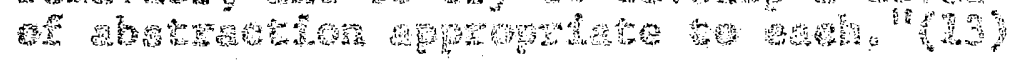

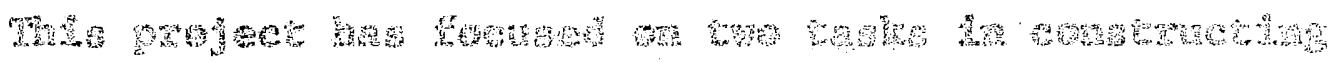

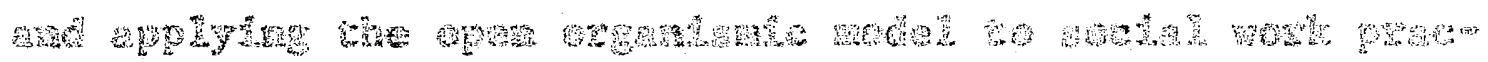

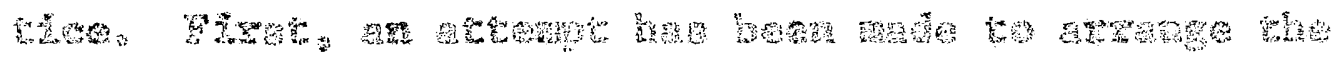

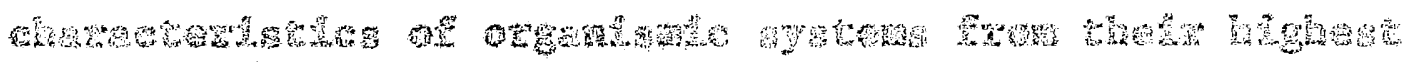

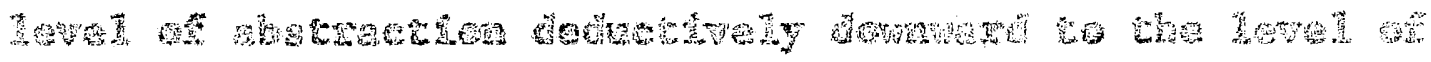




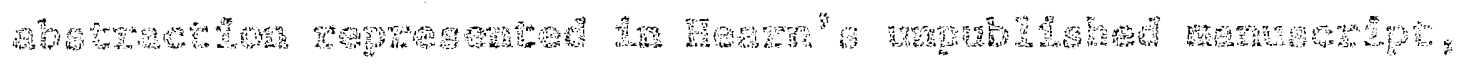

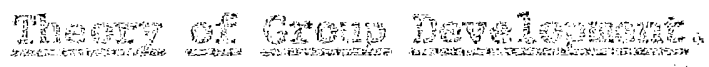

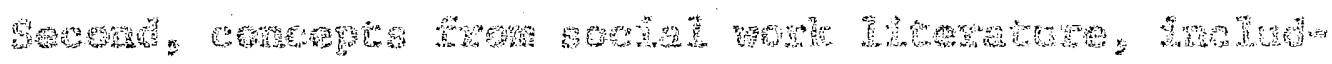

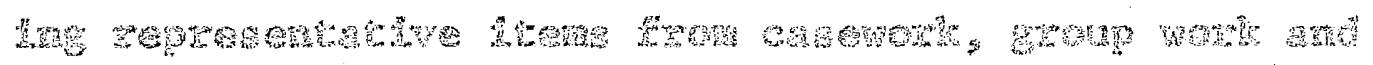

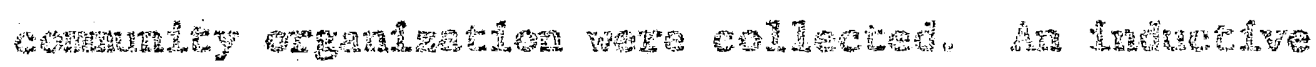

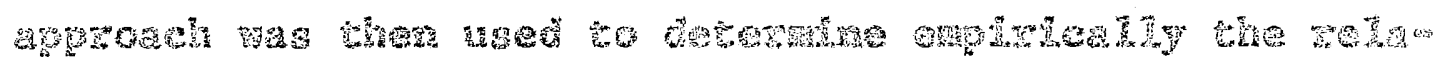

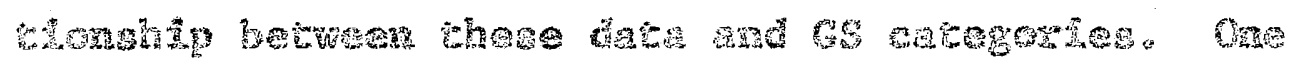

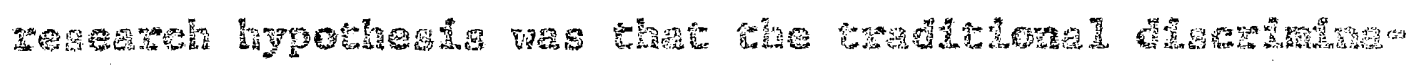

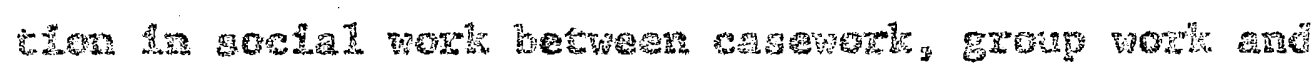
conmunt ory

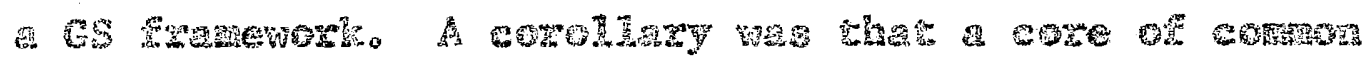

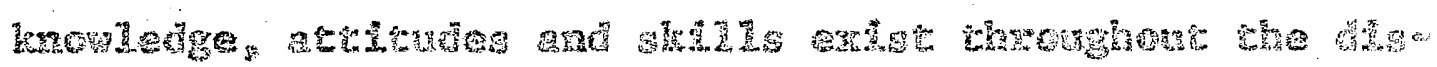

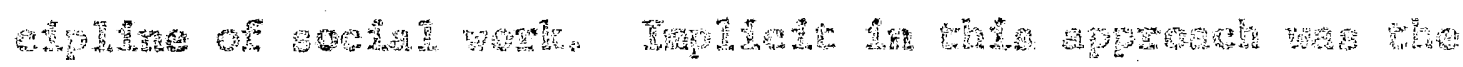

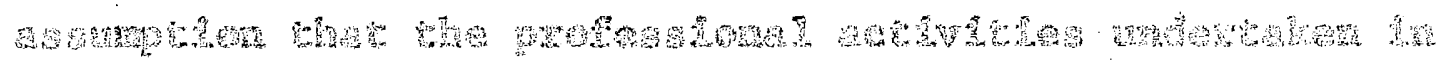

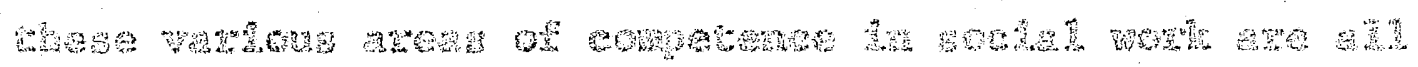

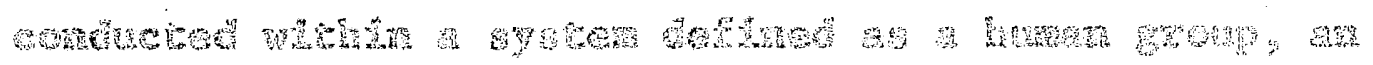

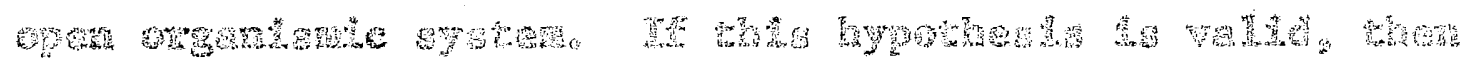
the of

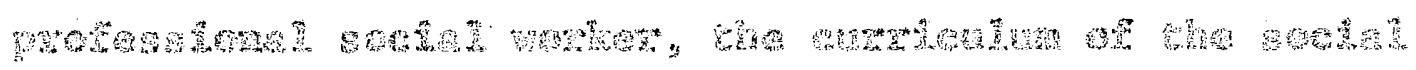

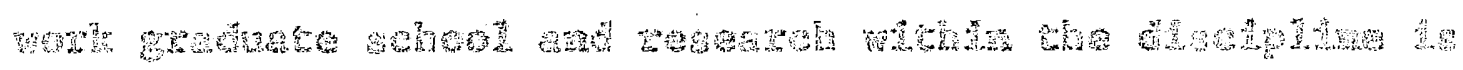
a)

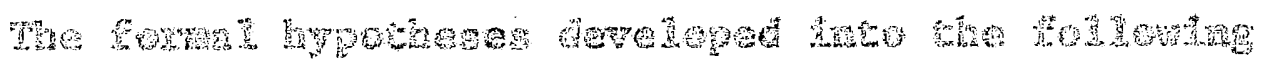

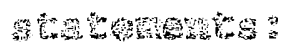

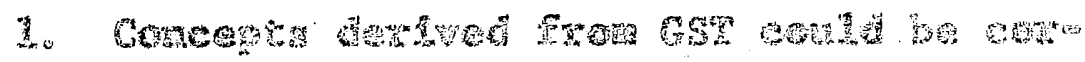

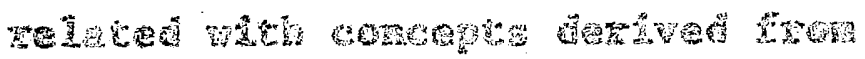

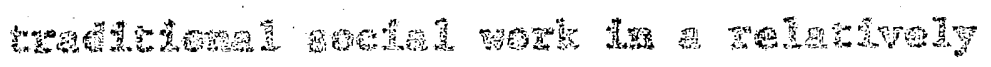

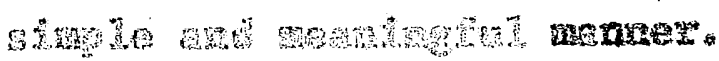




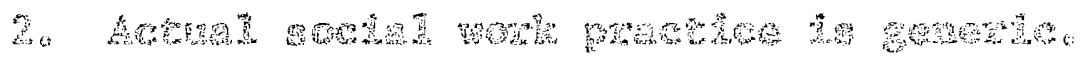

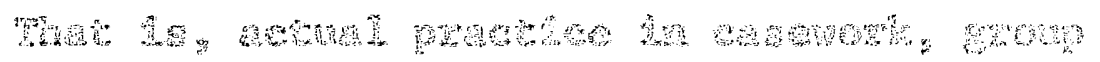

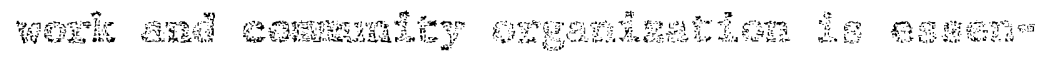

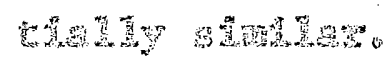

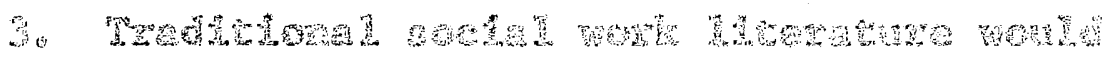

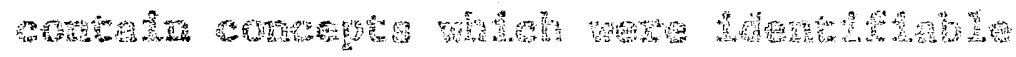

\section{and diserete.}

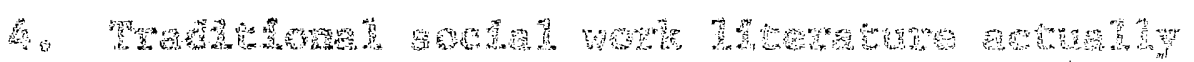

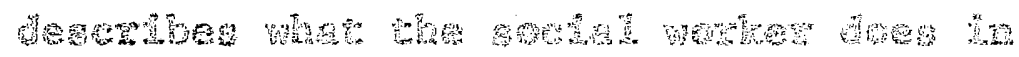
gractice.

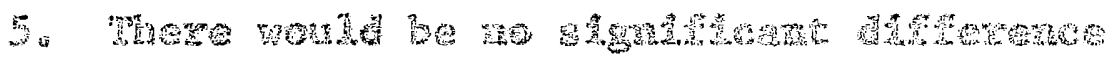

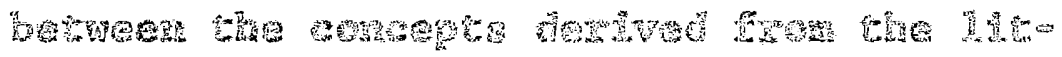

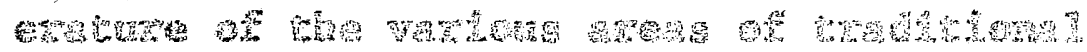

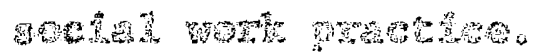

6. conderthen

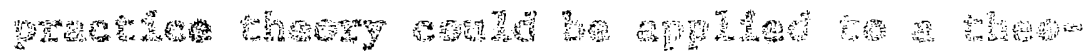

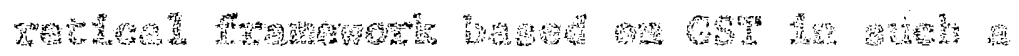

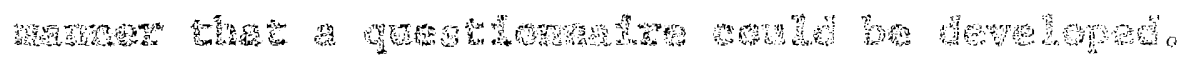

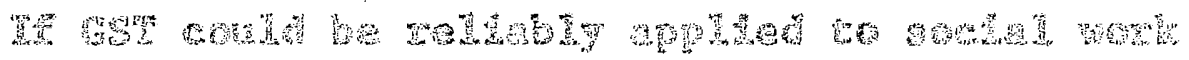

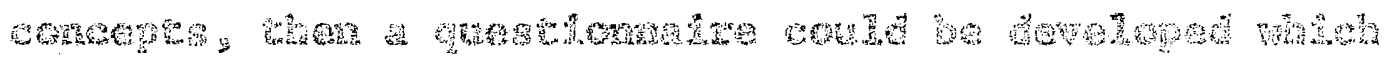

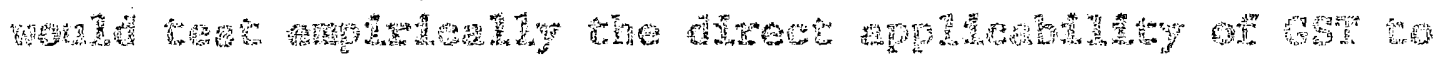

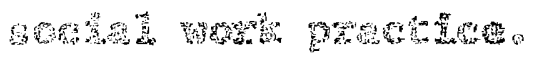

The ger

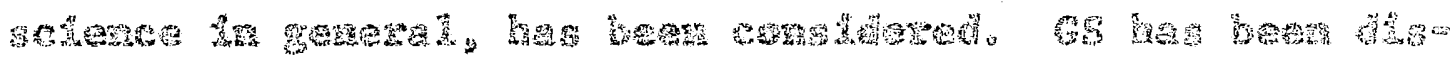

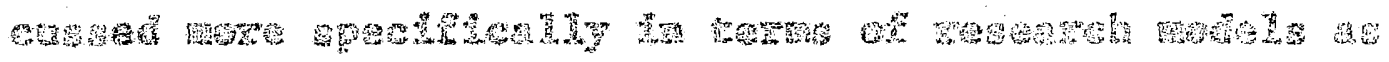

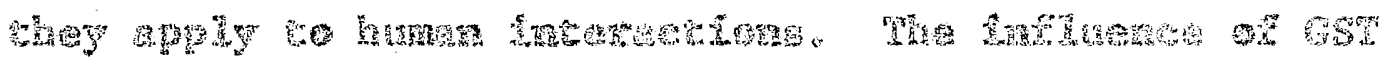




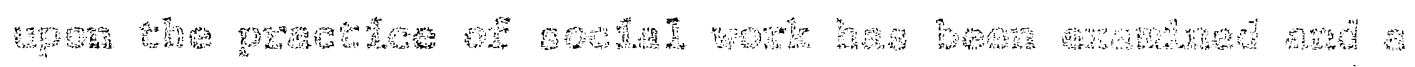

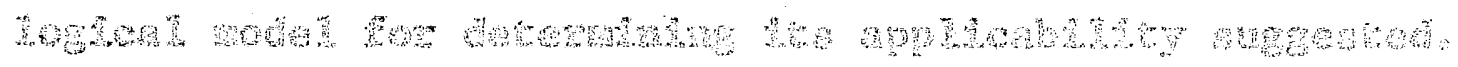

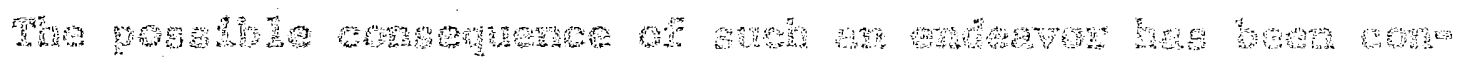

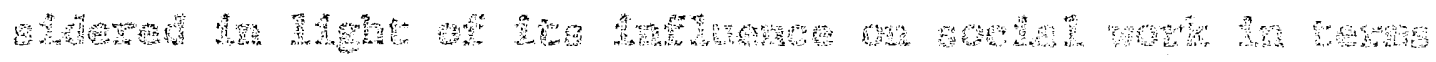

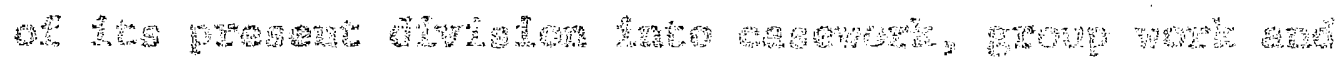

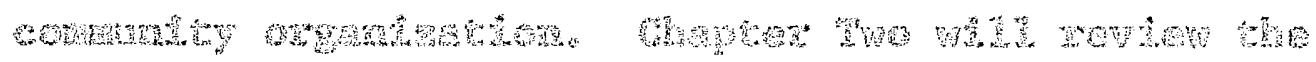

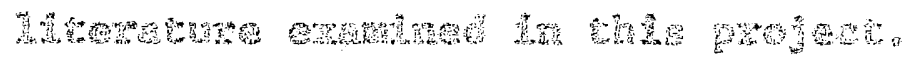




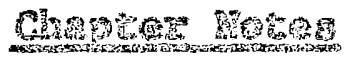

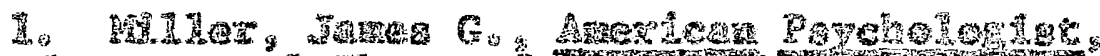

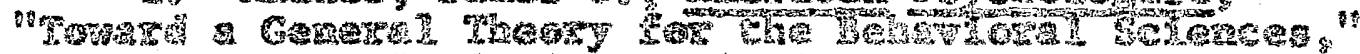
A A tex :

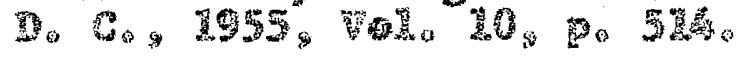

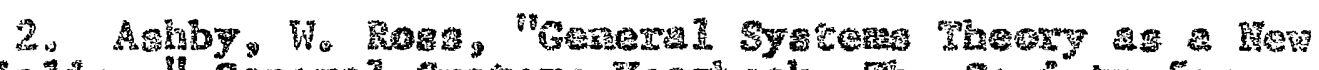

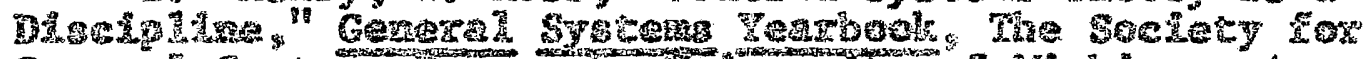

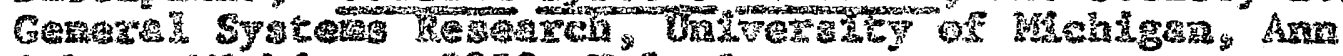

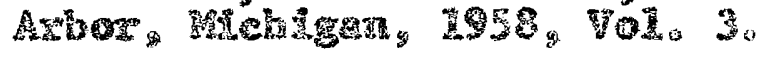

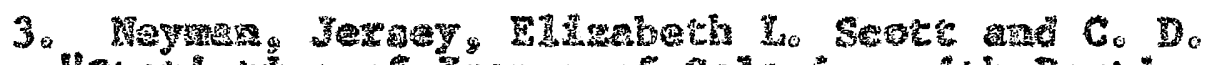

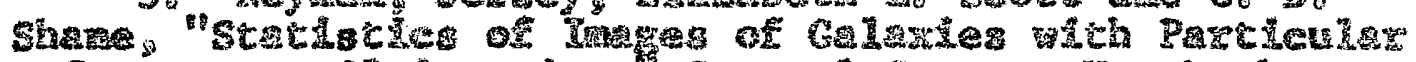

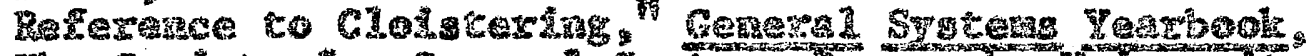

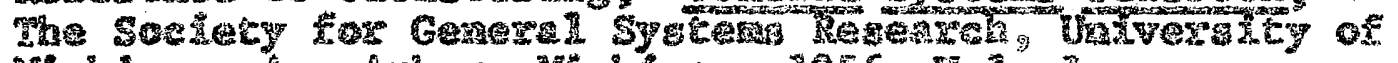

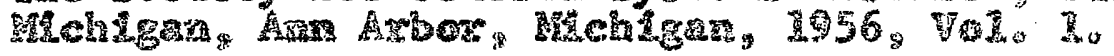

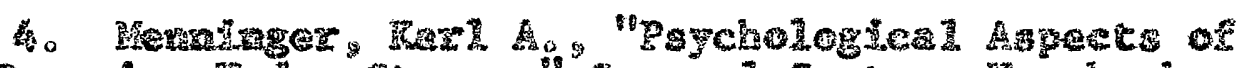

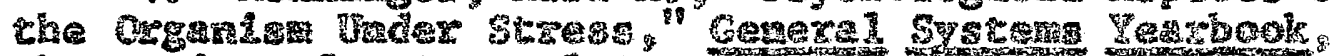

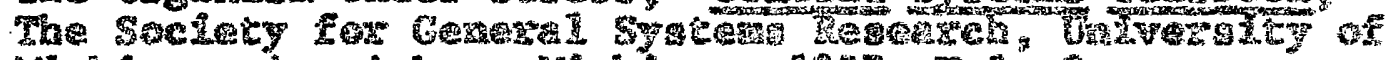

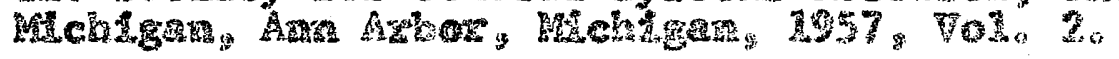

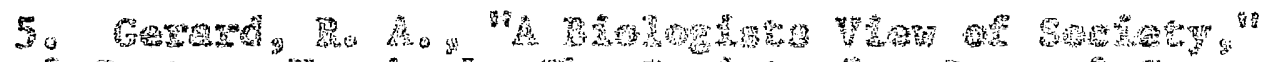

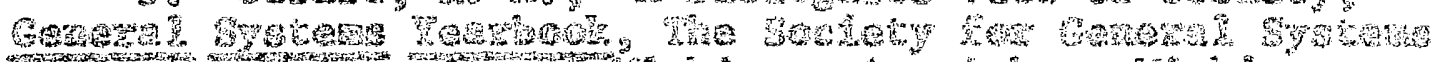

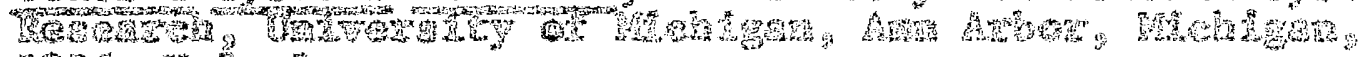

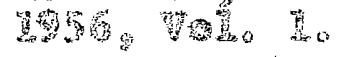

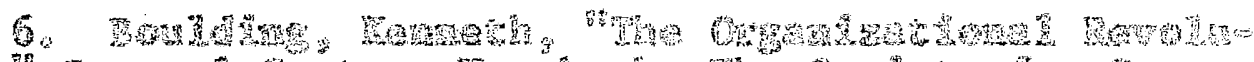

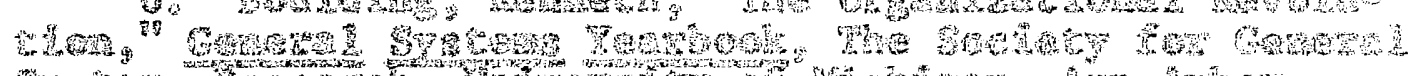

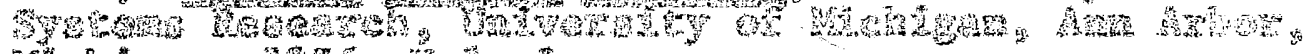

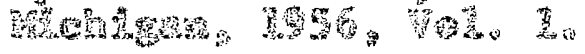

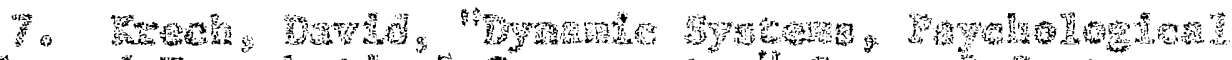

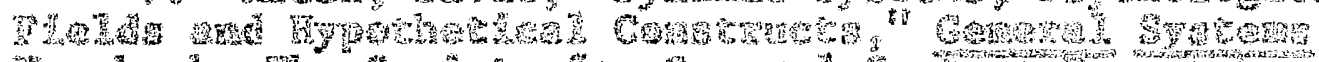

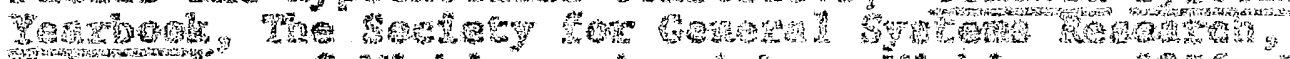

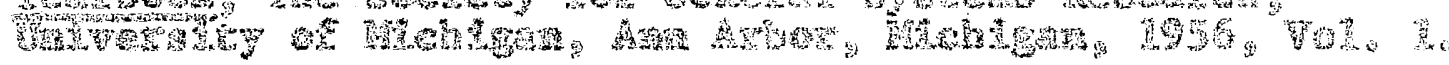

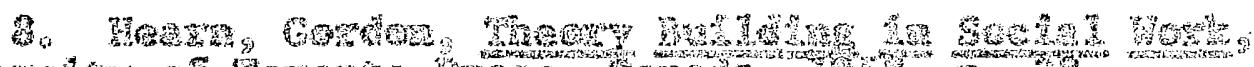

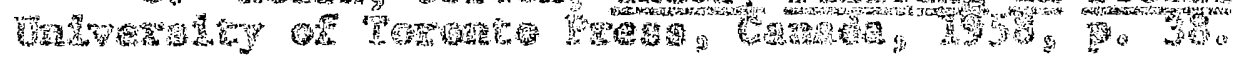

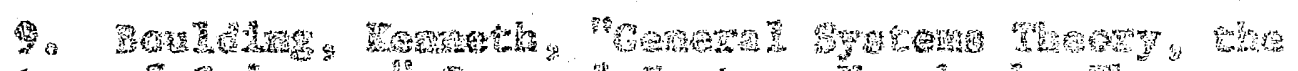

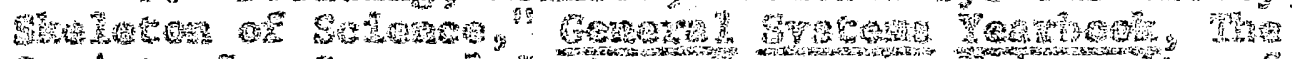

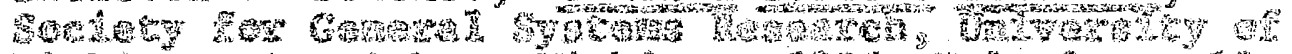

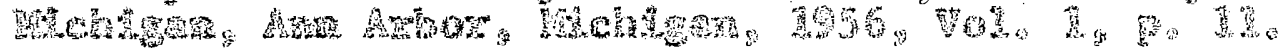




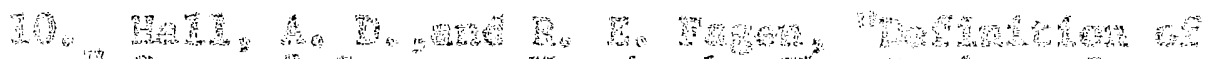

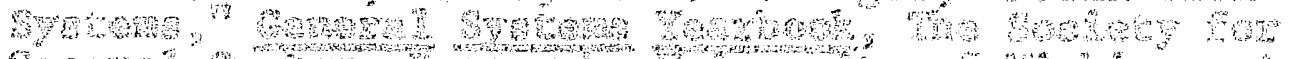

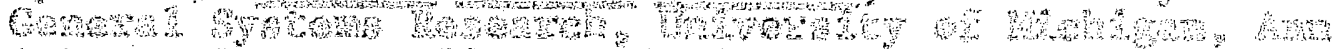

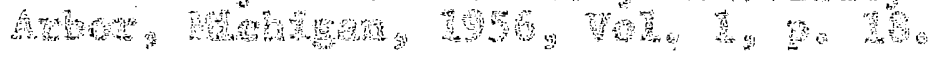

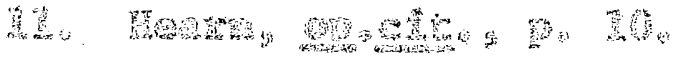

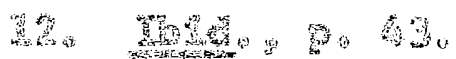

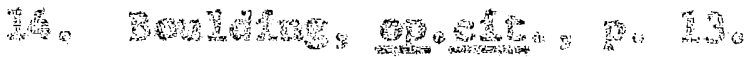




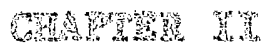

ME

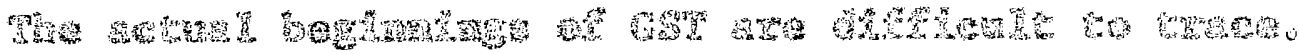

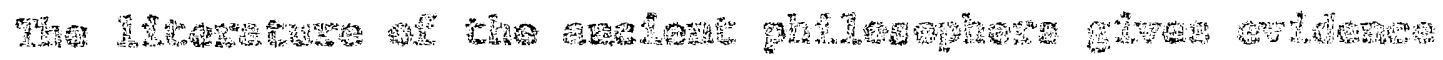

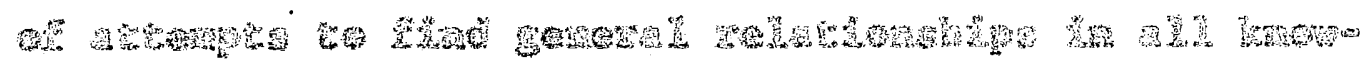

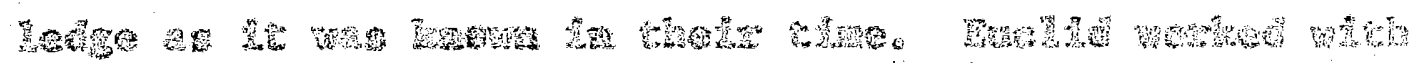

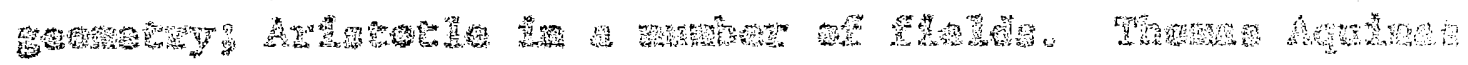

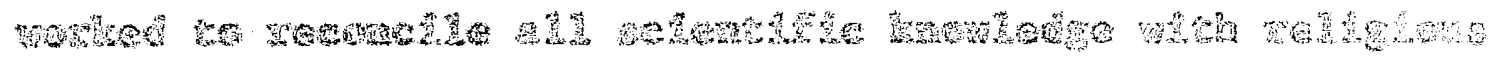

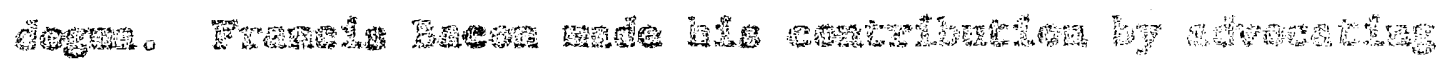

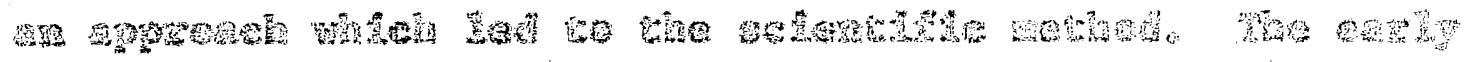

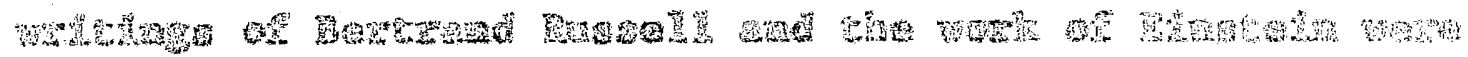

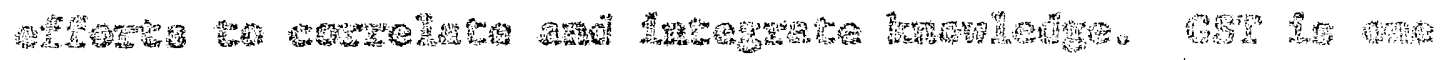

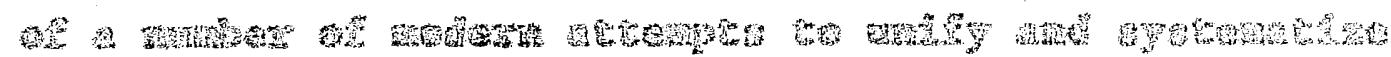

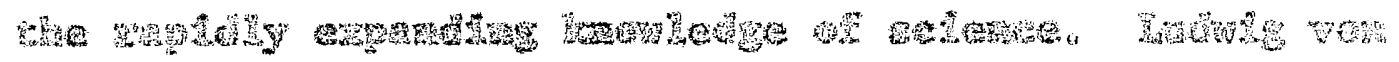

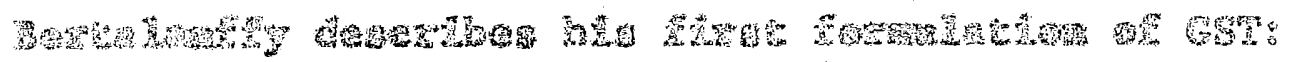

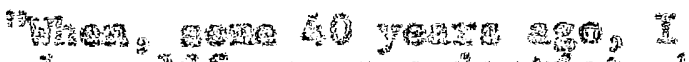

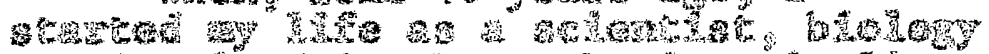

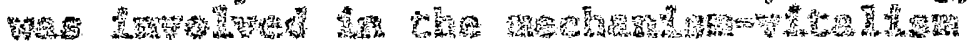

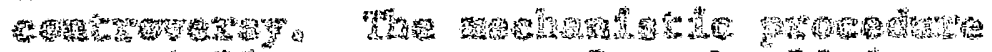

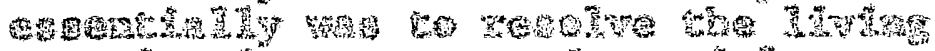

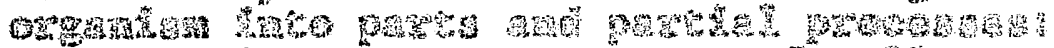

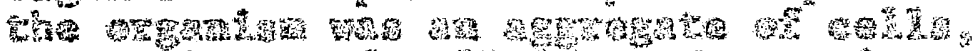

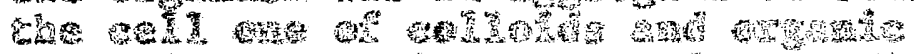

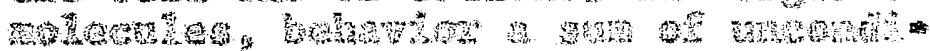

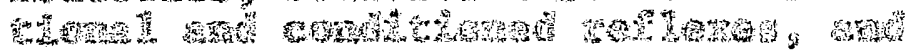

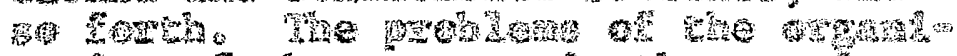

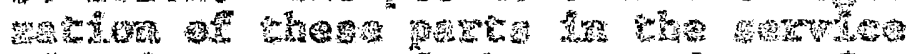

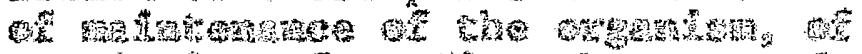
5. 焦

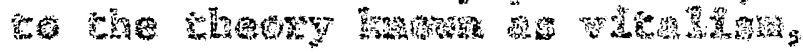




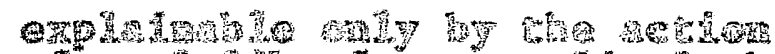
of taven

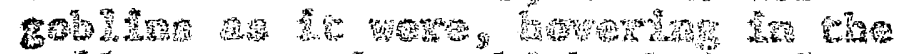

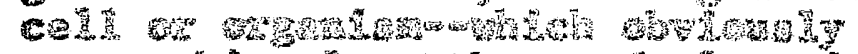

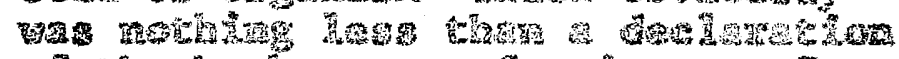

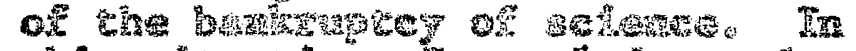

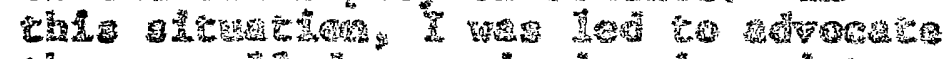
6

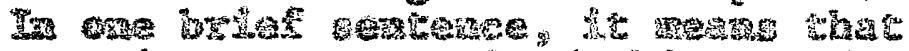

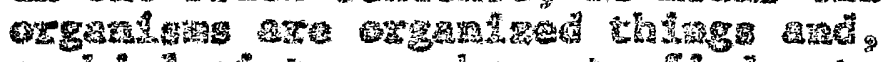
as 6L2 bog

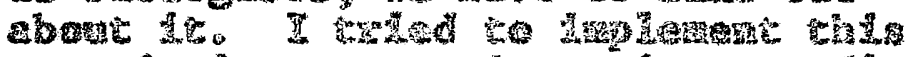
ormands

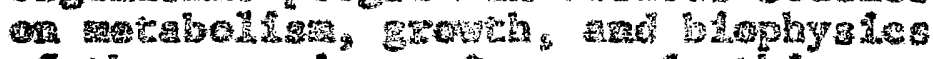

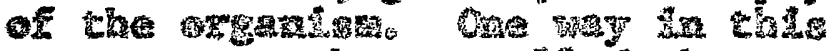
respere we the somenaled cheery of

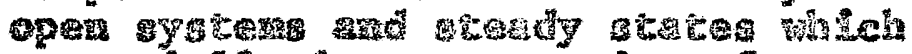

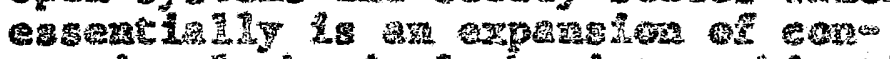

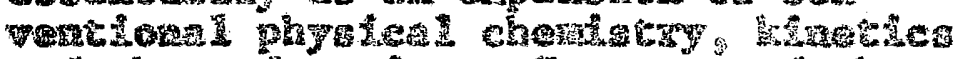

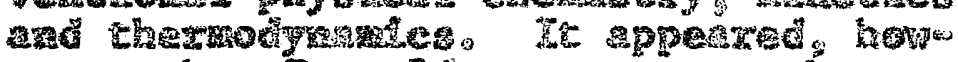

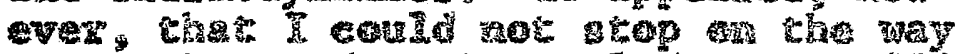
coe colsen

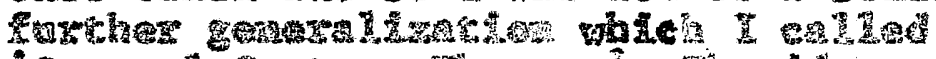

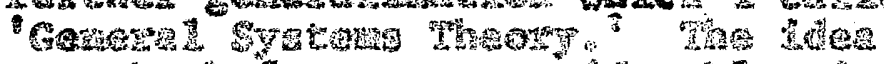

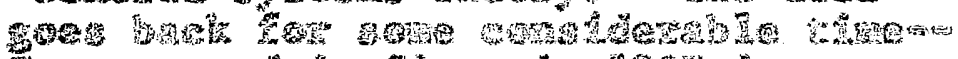

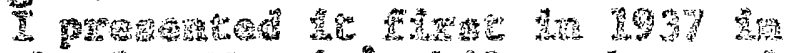

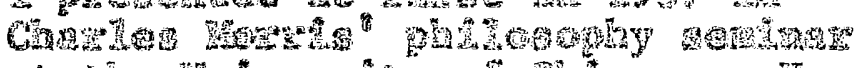

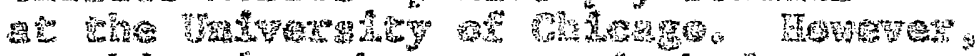

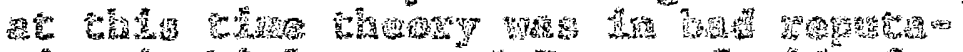

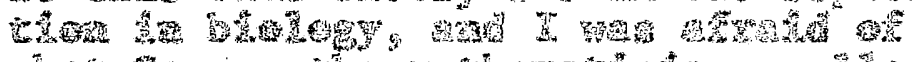

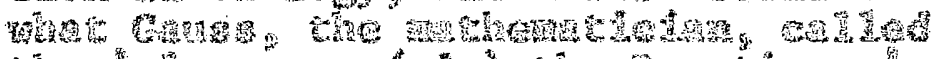

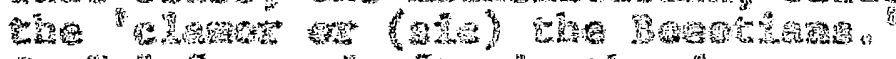

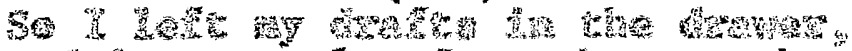

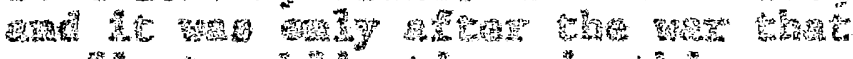
蚁 D.p.

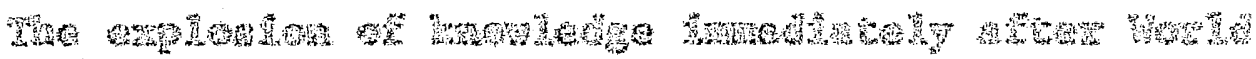

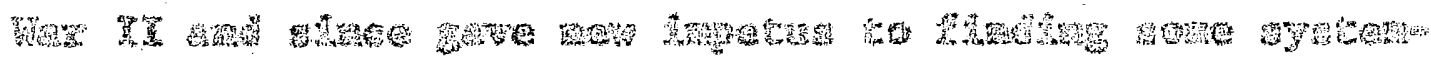

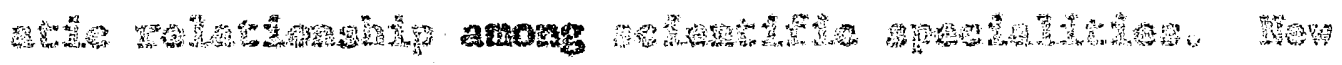

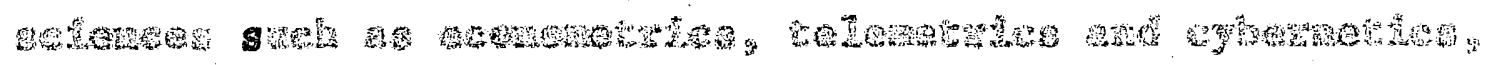

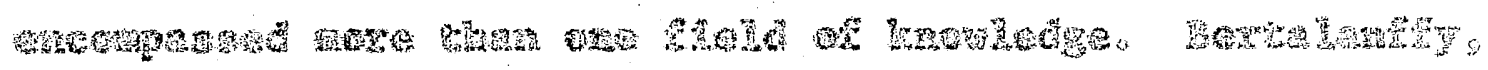

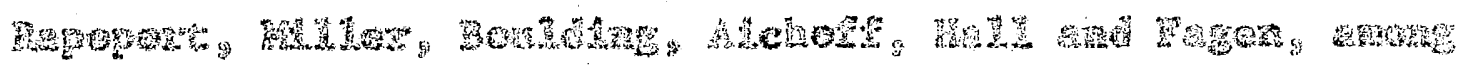
and 


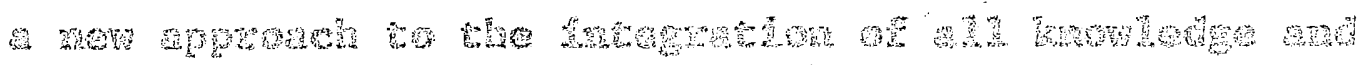

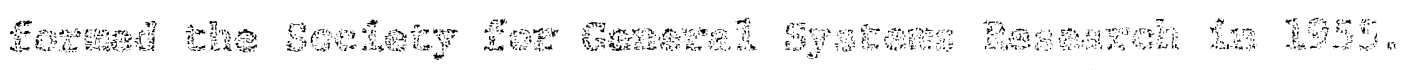

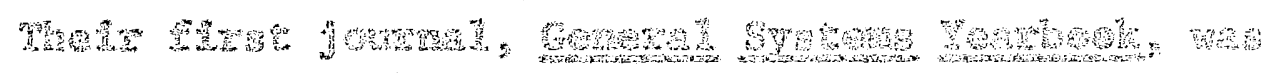

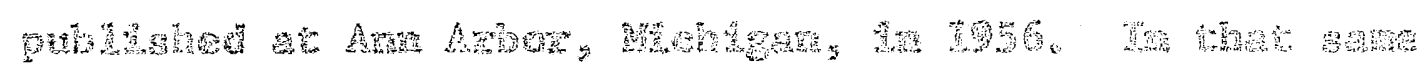

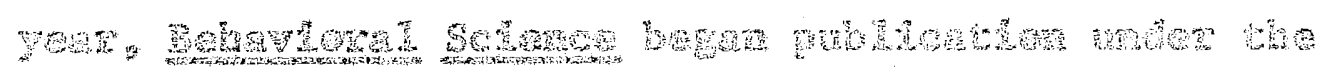

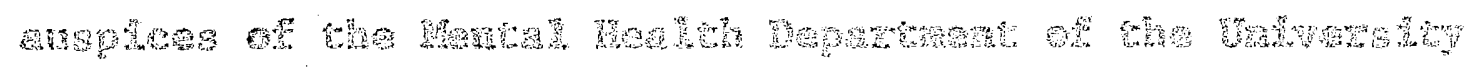

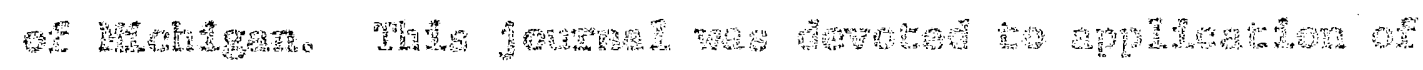

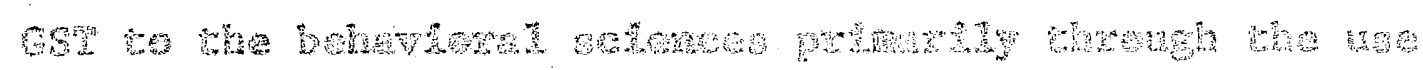

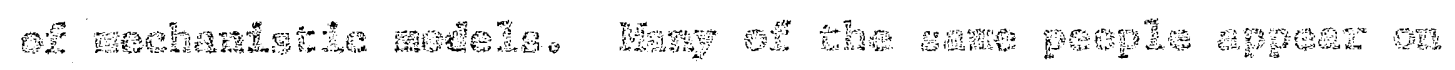

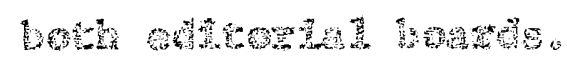

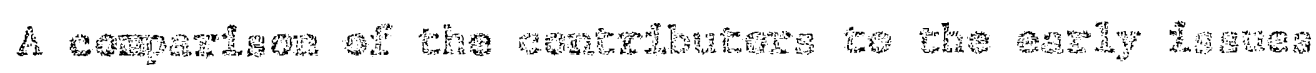

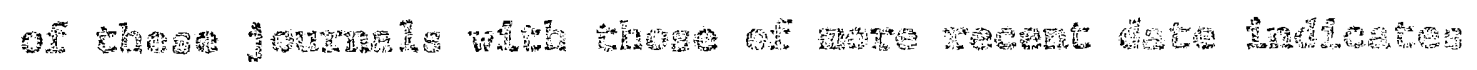

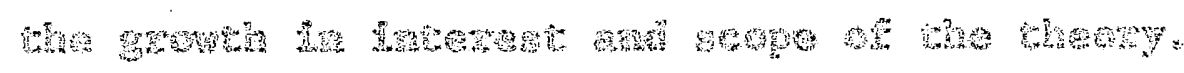

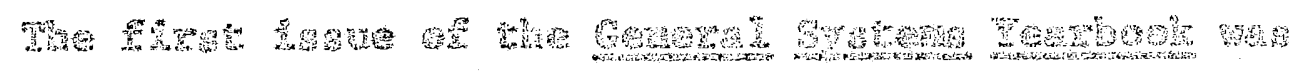
Now

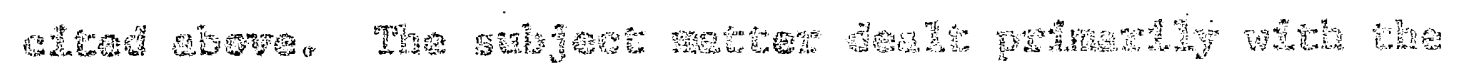

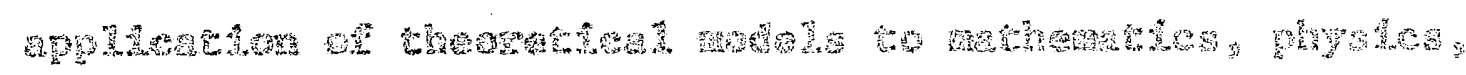

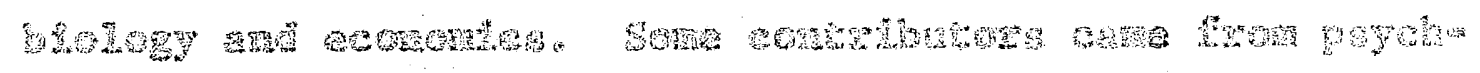

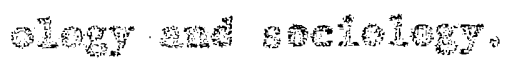

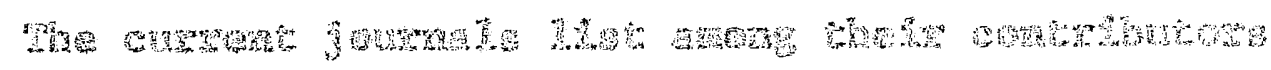

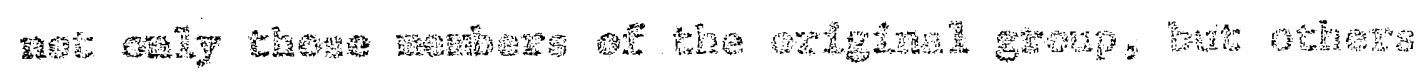

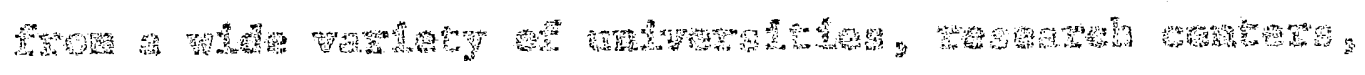

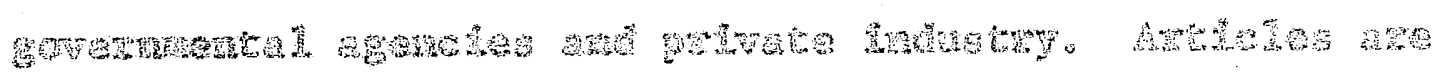
Hy

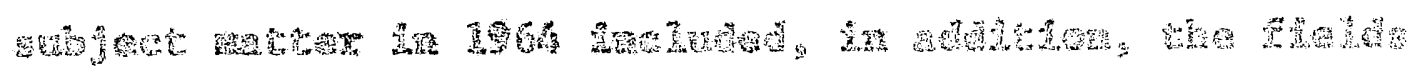




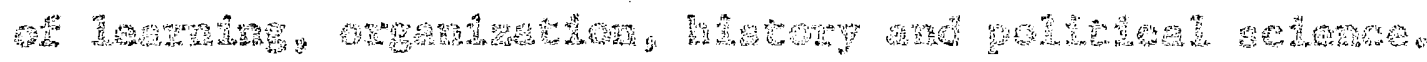

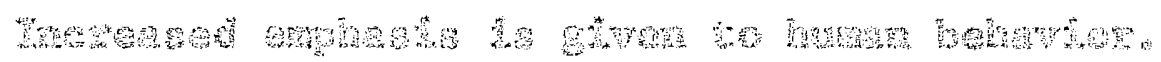

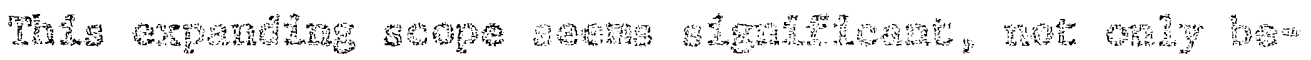

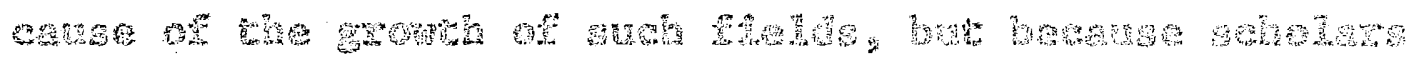

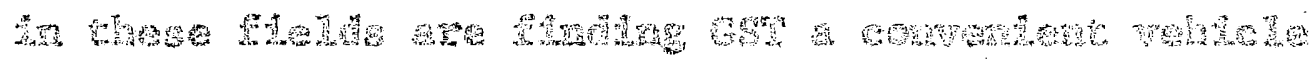

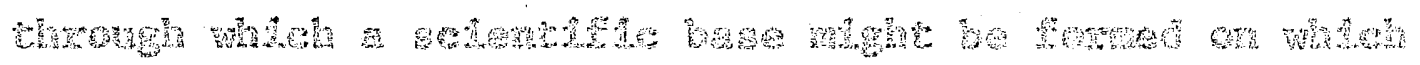

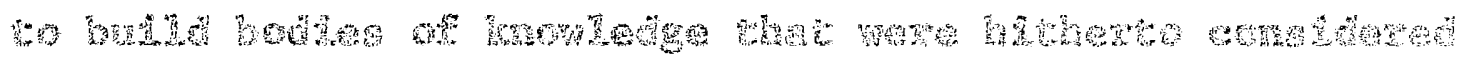

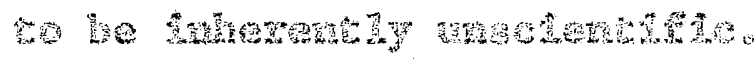

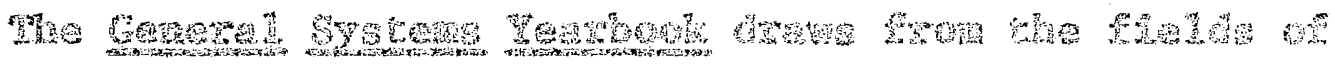

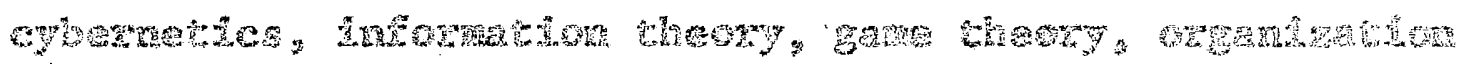

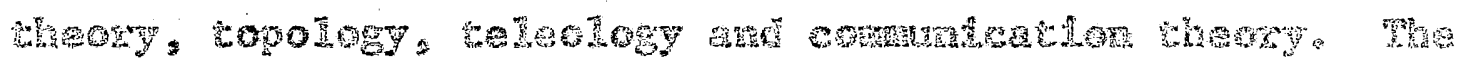

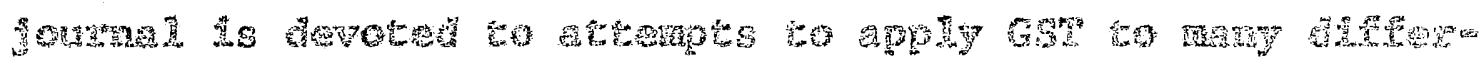

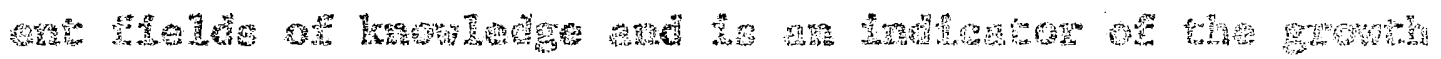

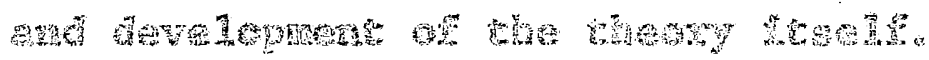

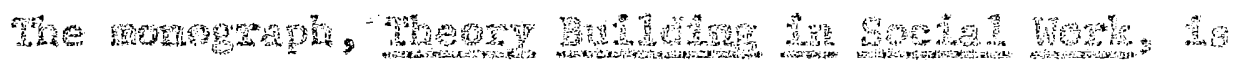

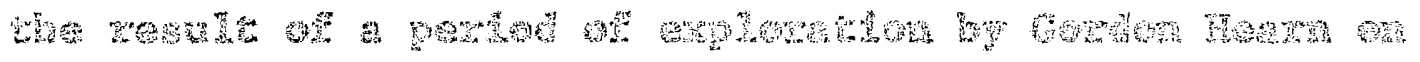

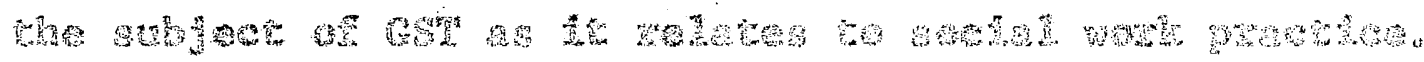

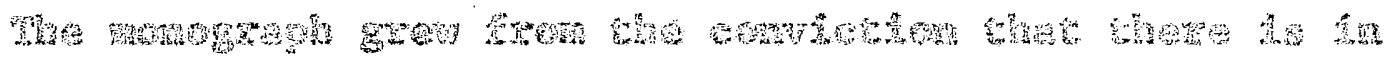

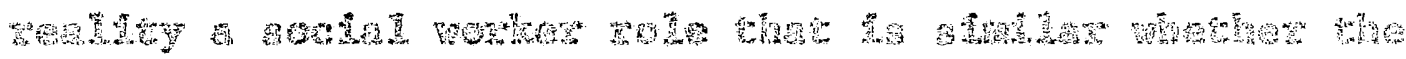
Goor

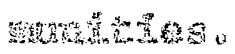

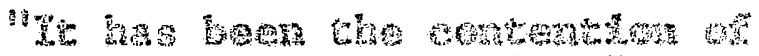

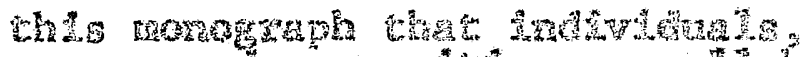

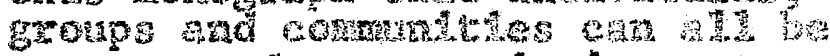

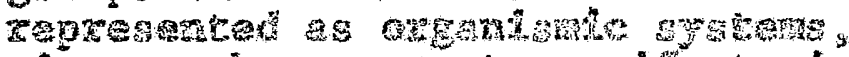

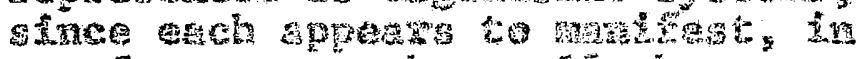

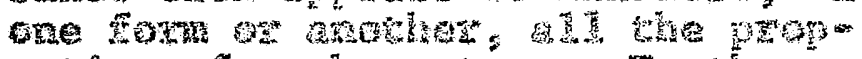

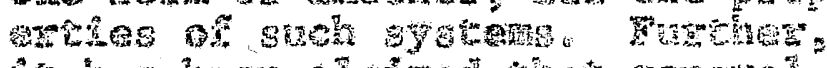

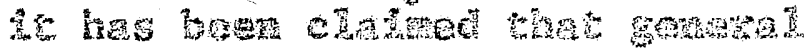




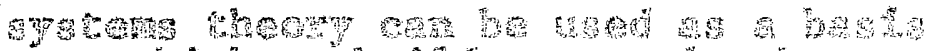

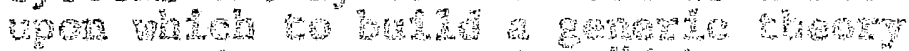

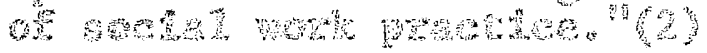

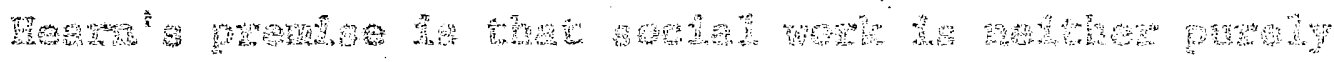

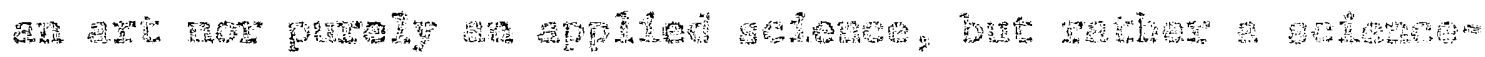

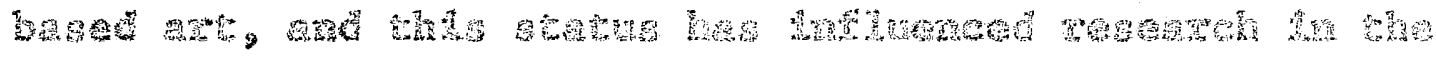

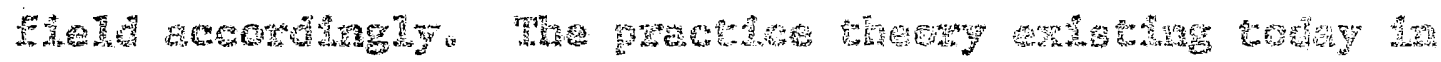

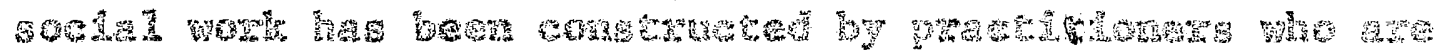

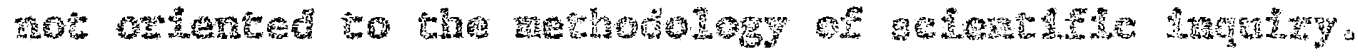
Sy

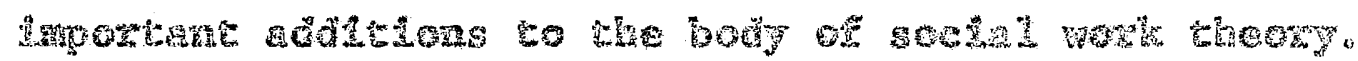

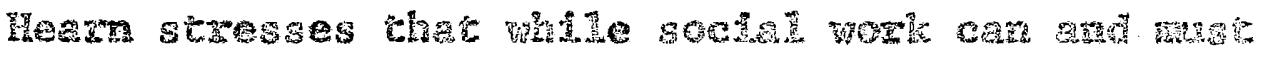

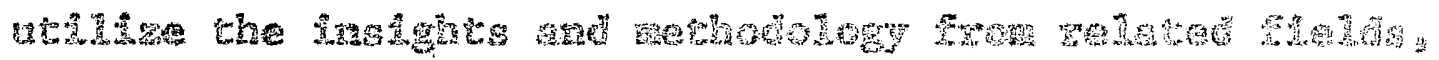

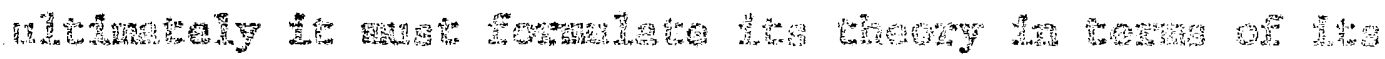

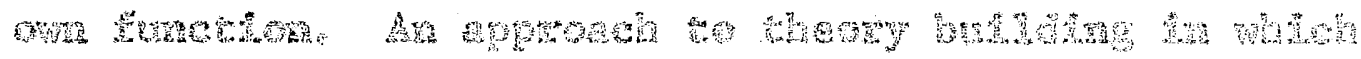

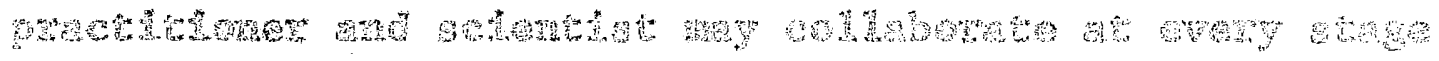

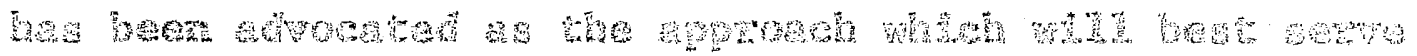

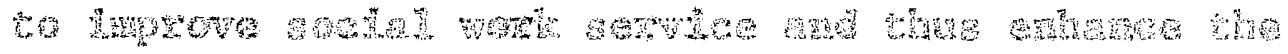
matress 20 on

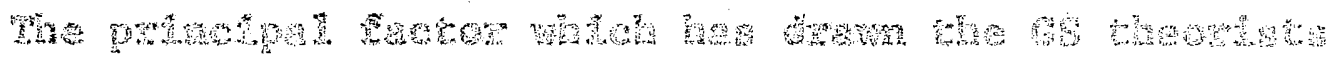

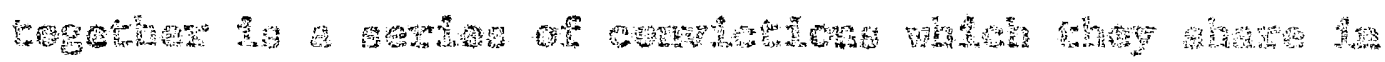

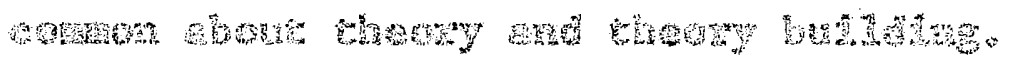

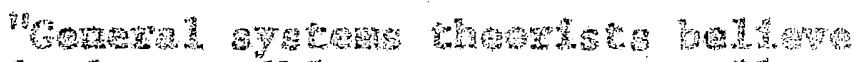

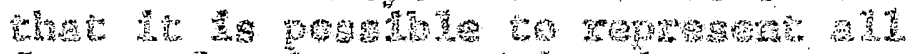

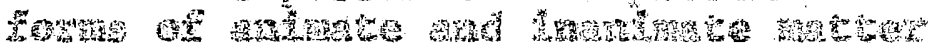

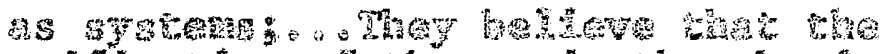

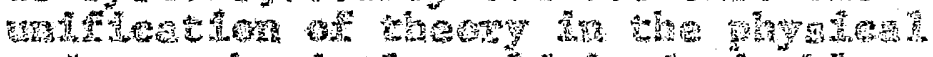

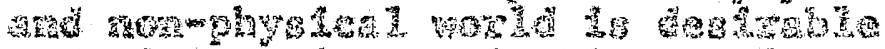
G

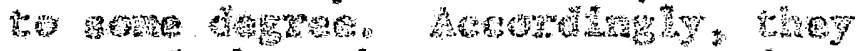

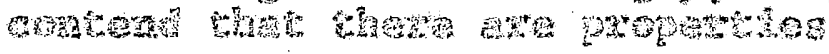


whited a

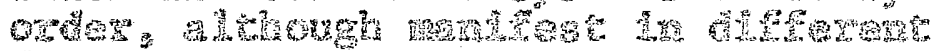

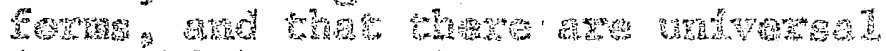
Lav whth

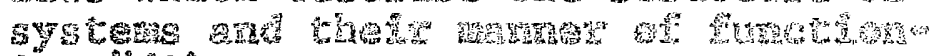
Ling.

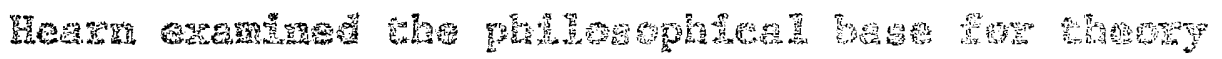

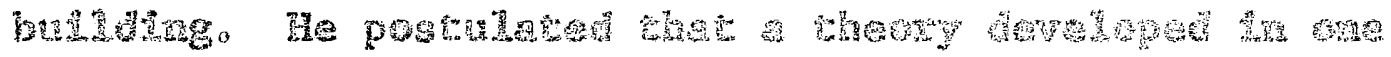

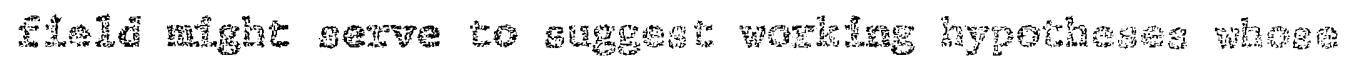

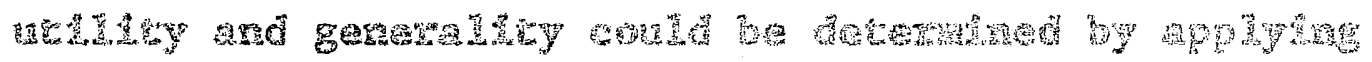

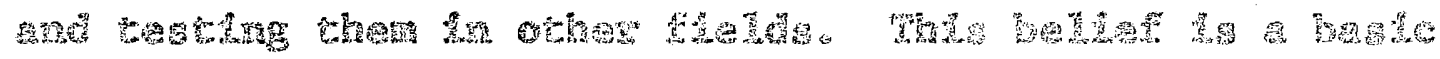
come of $65 n^{\circ}$

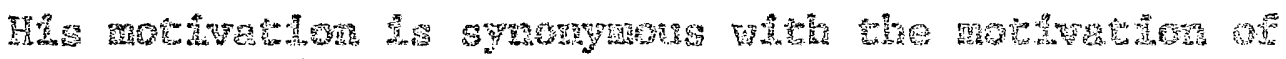

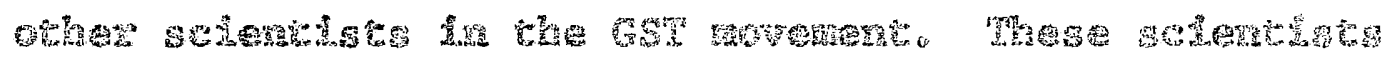

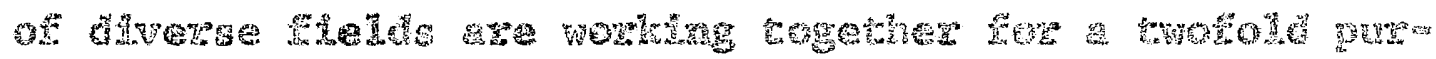

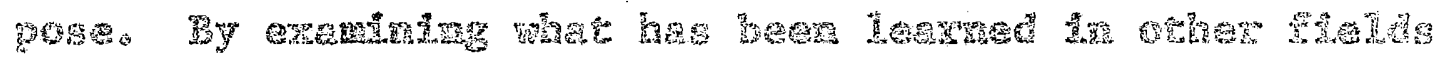

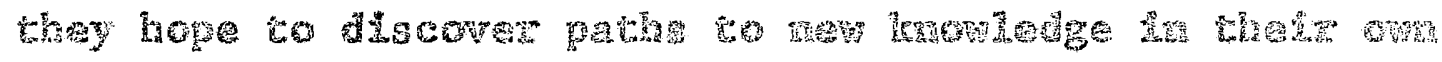

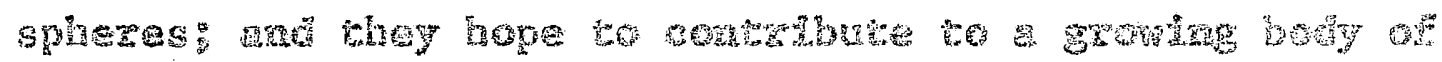
Hidited setares.

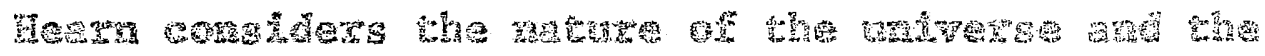

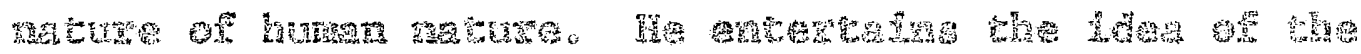

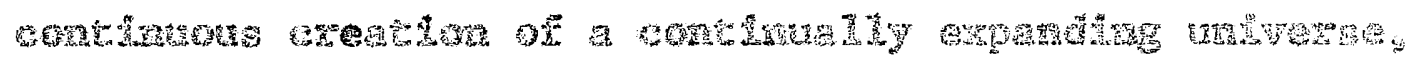

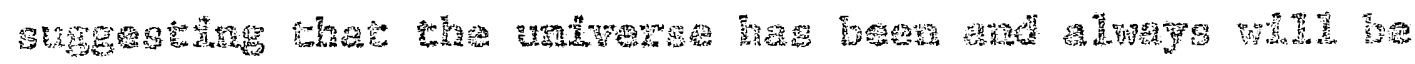

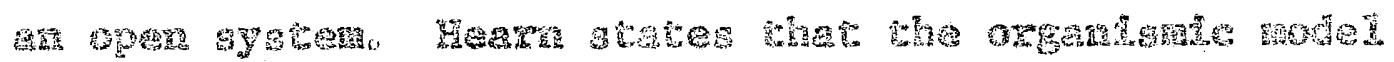

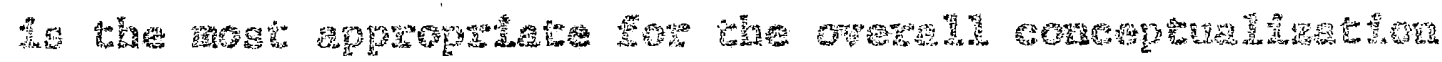

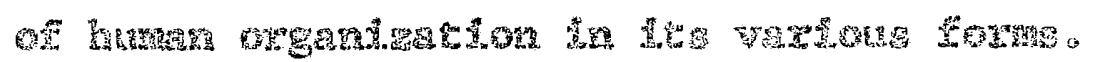

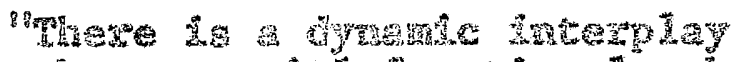

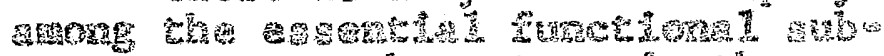

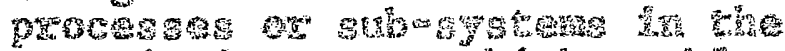

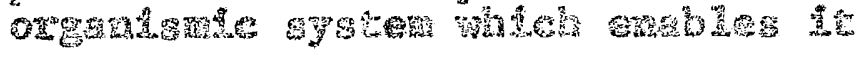




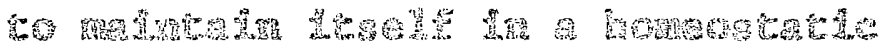

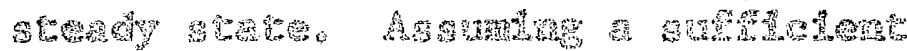

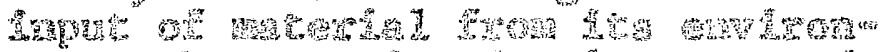

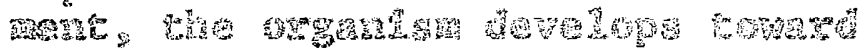

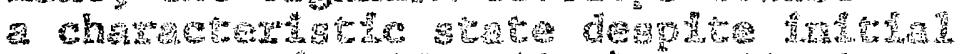
condzing

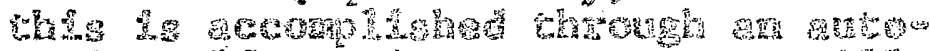

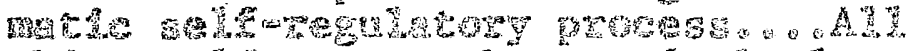

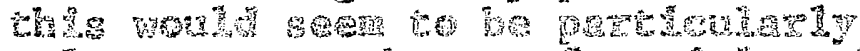

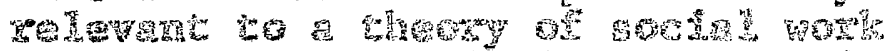

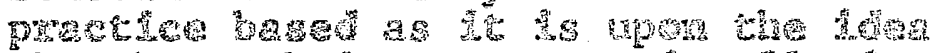

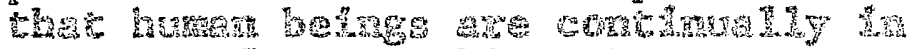

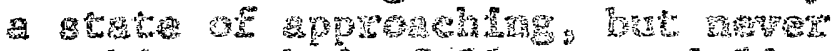

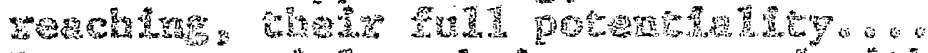

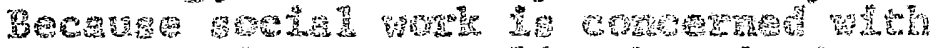

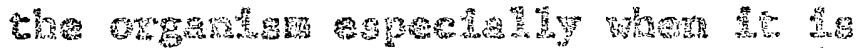

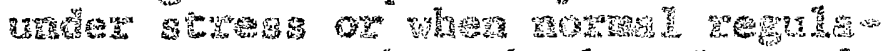

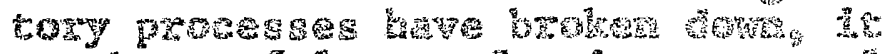
my waty to he

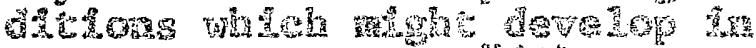

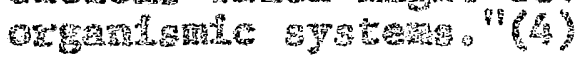

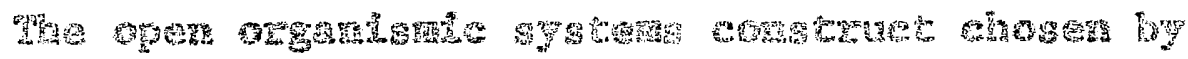

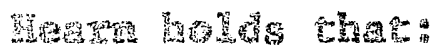

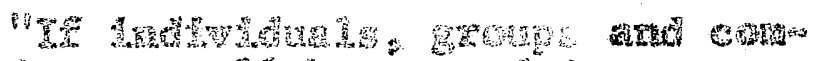

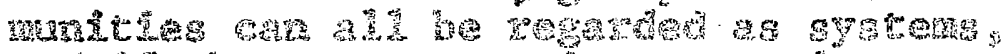

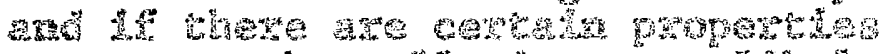

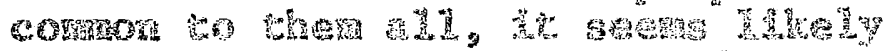

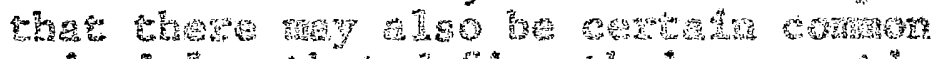

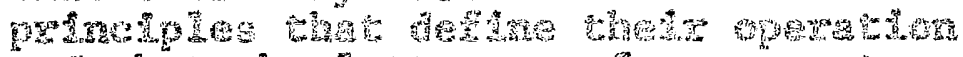

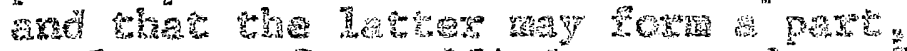

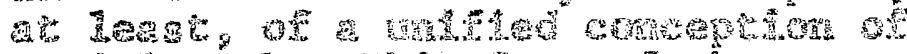
Borde

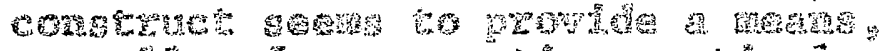

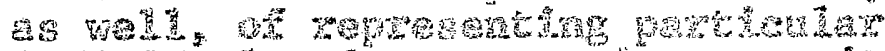

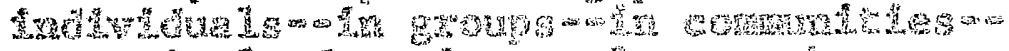

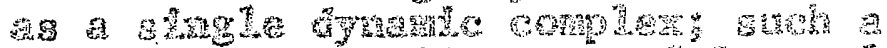
zergrads a

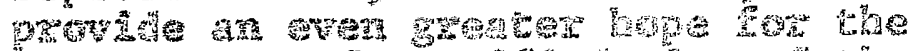

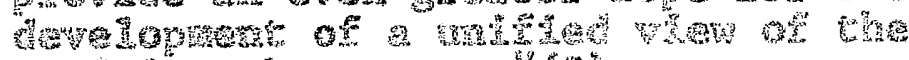
gotites

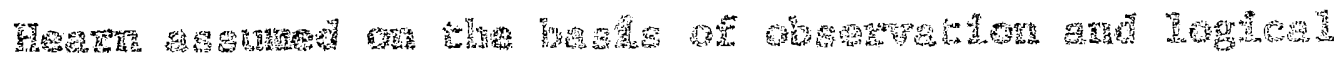

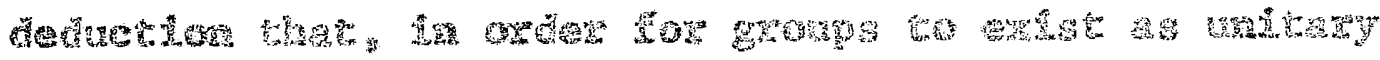

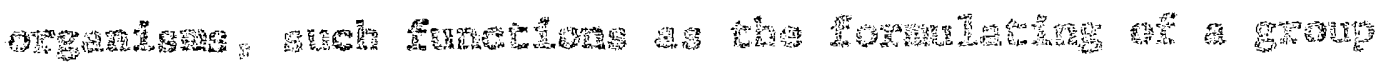




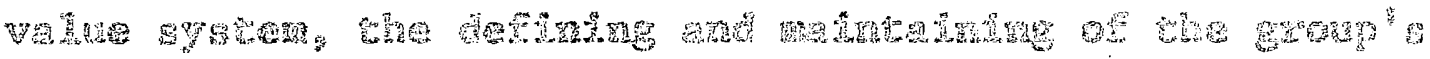

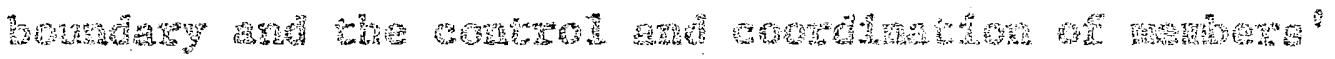

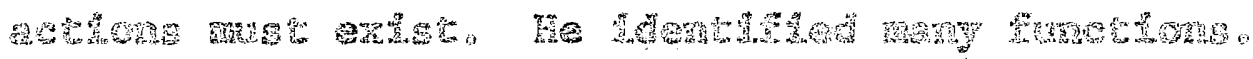

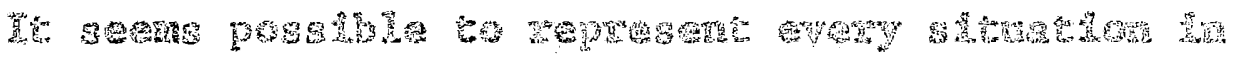

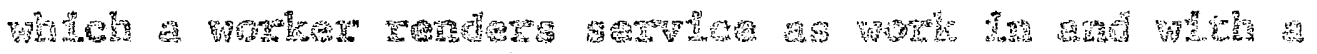

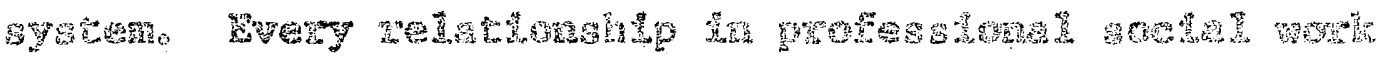

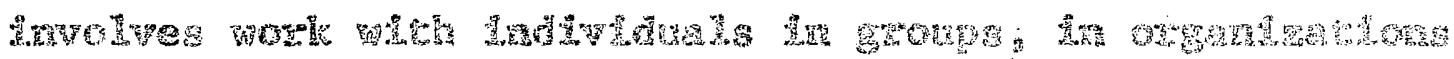

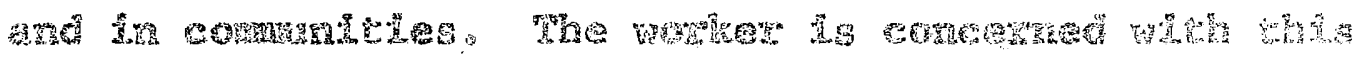

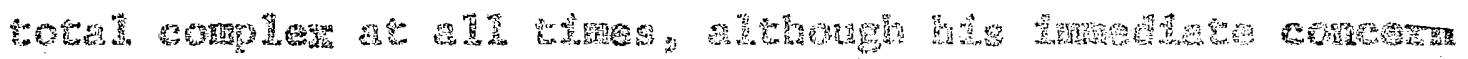

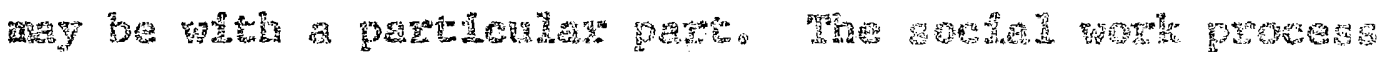

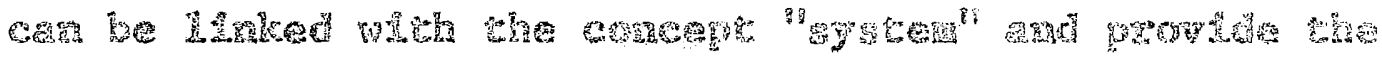

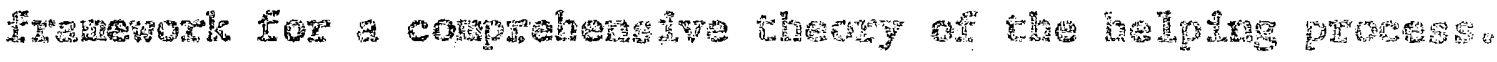

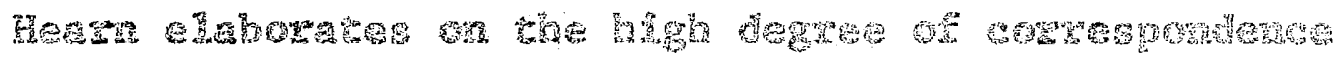

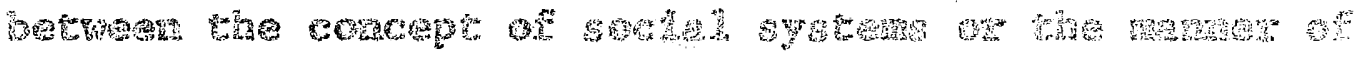
comed I

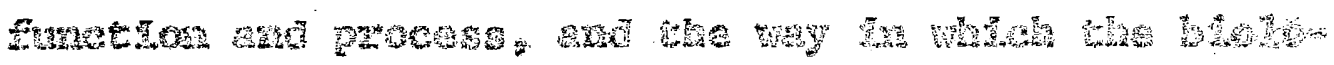

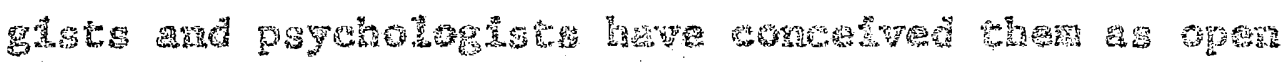

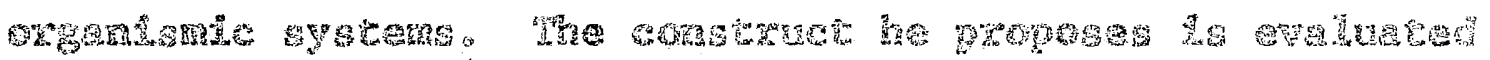

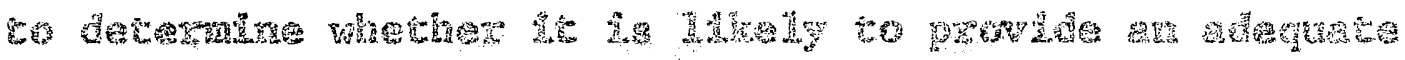
.

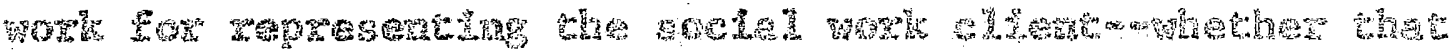

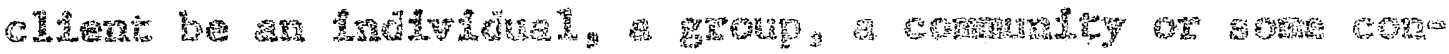

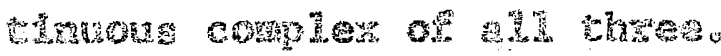

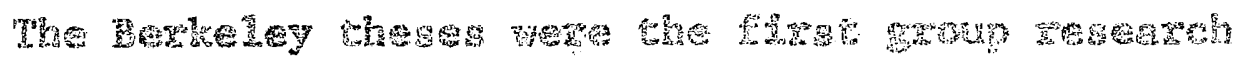

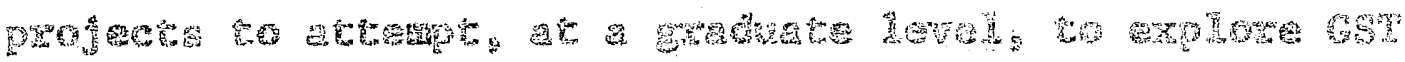

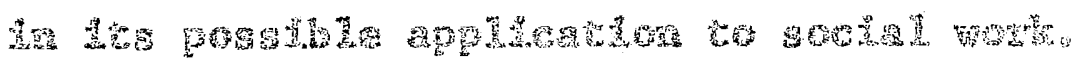




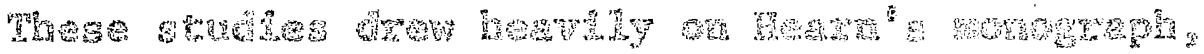

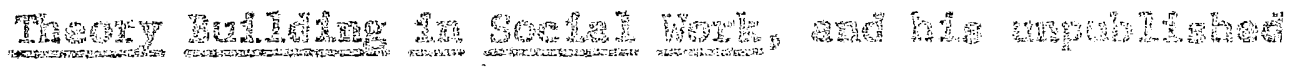

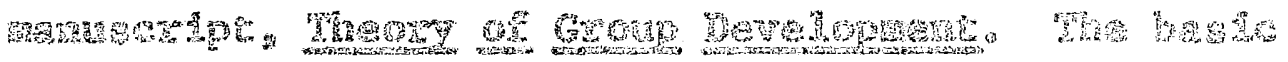
A

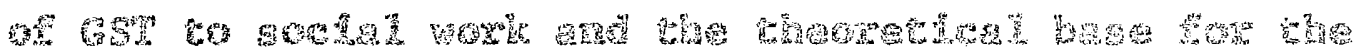

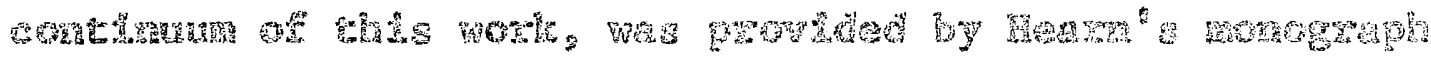

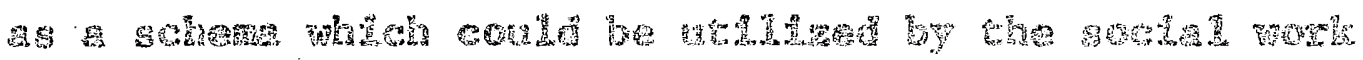

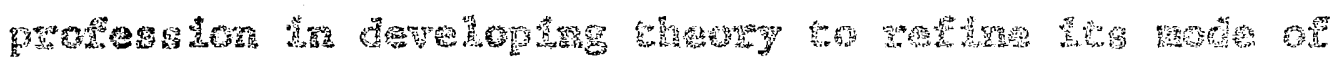
Pra

S4

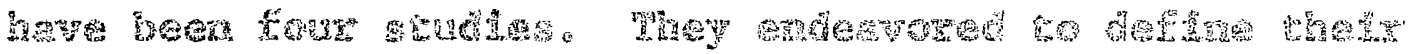

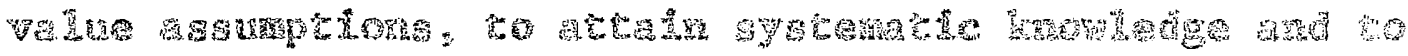

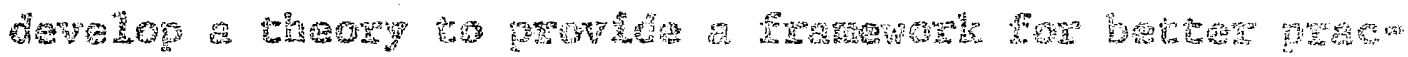
L2.

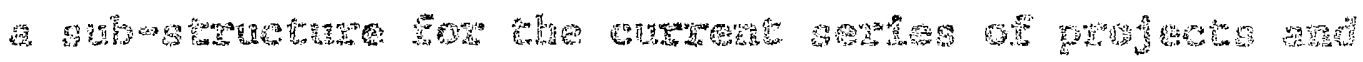

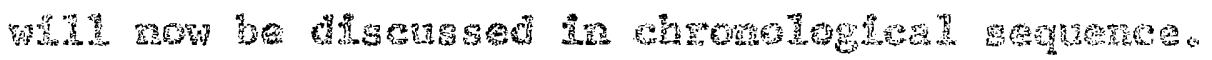

920 .

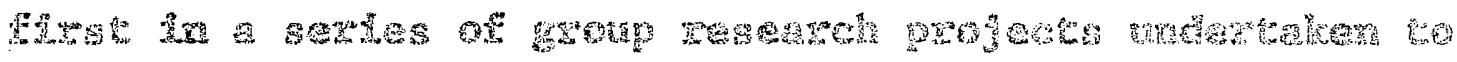

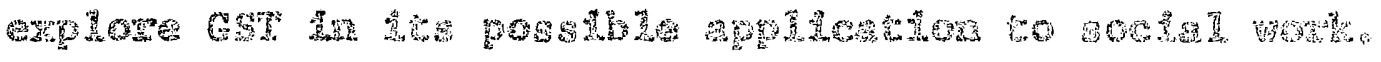

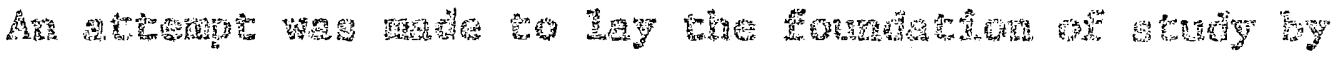

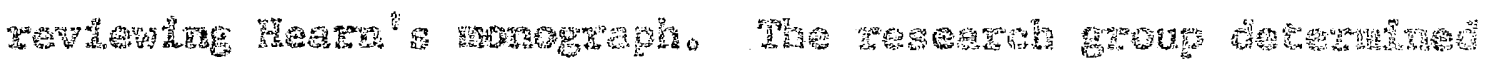

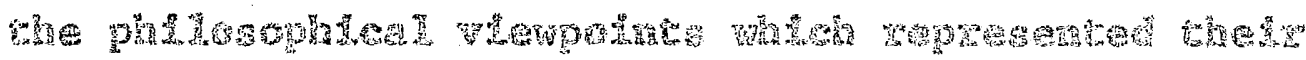

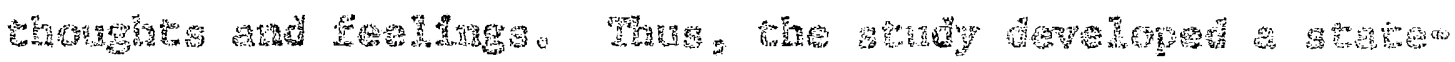

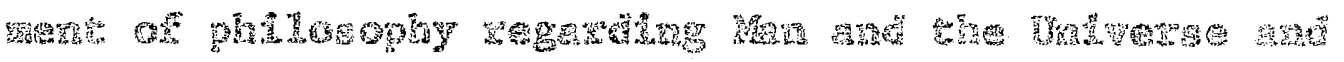

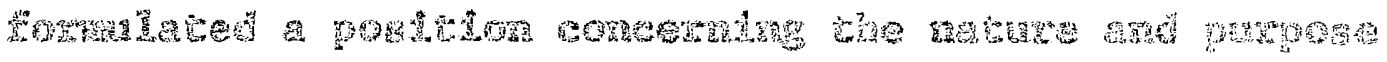
2 7 M 


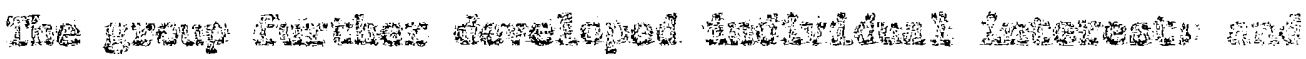

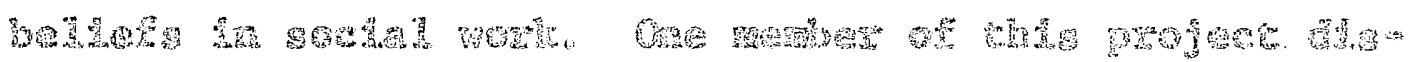
ang

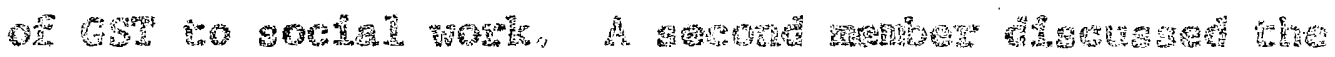

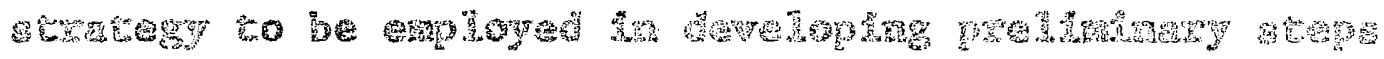

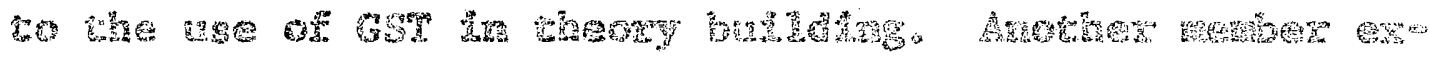
plored the poss

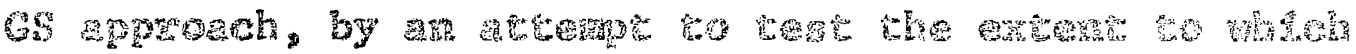

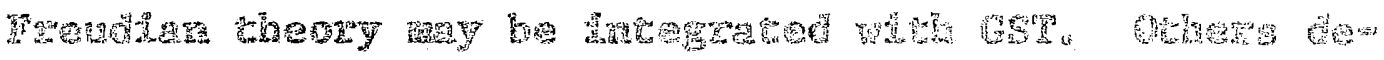

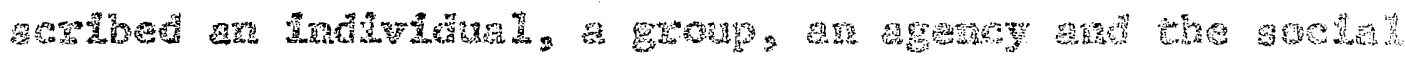

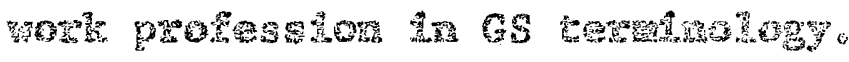

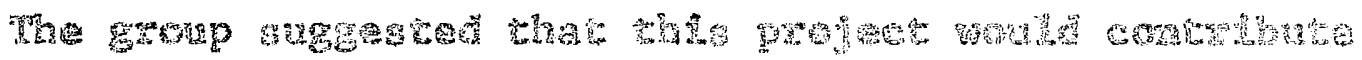

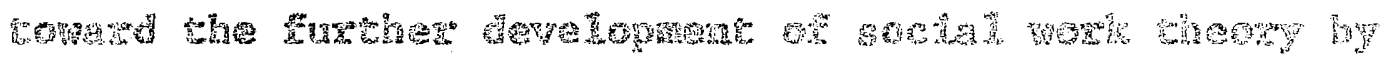

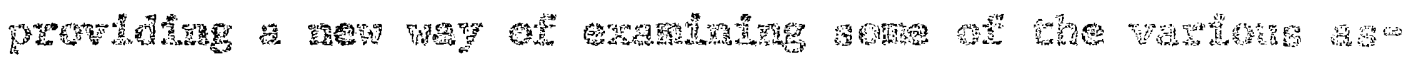

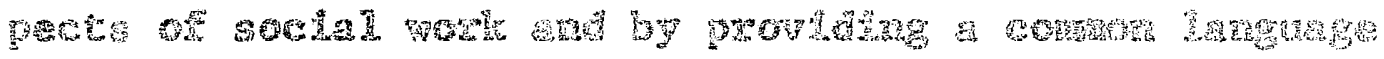

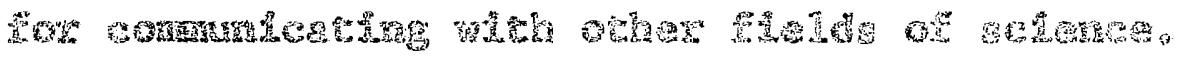

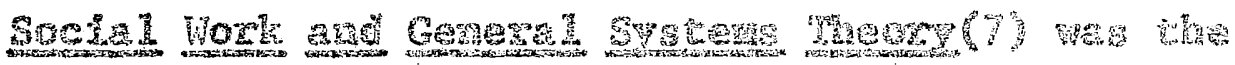

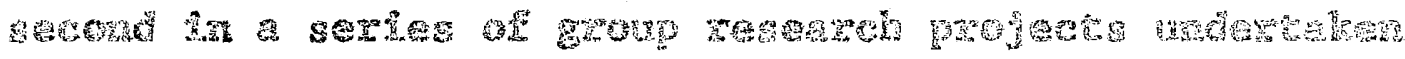

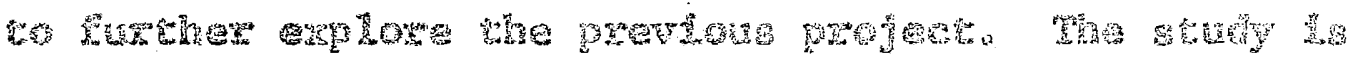

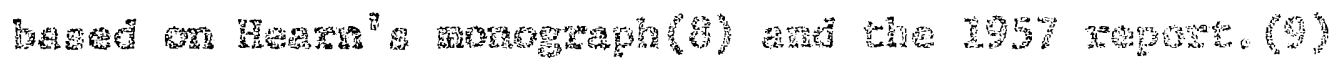

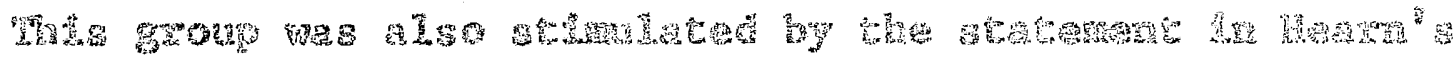

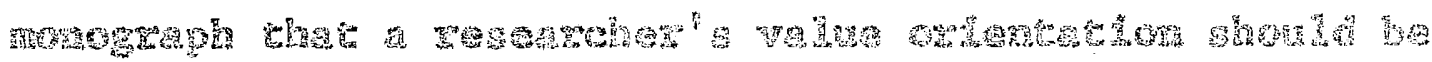

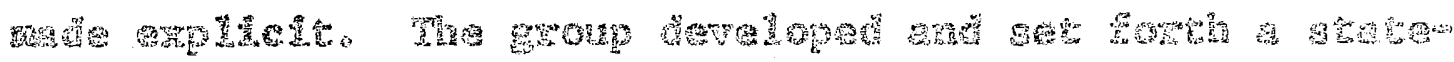

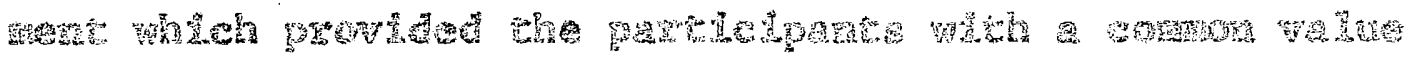

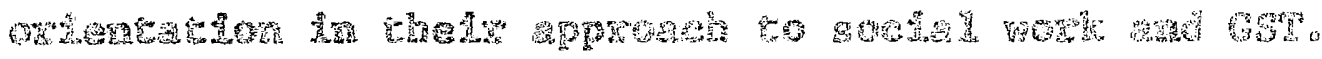




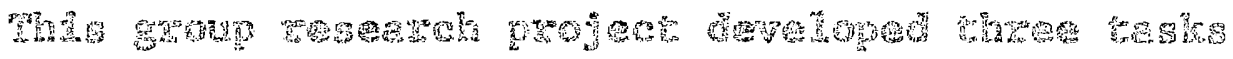

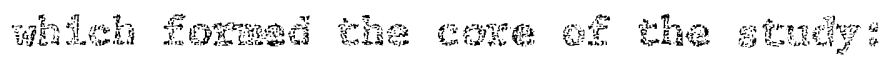

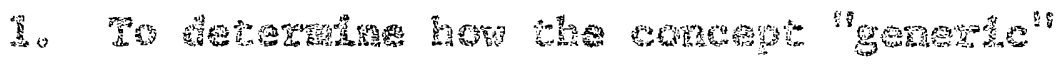

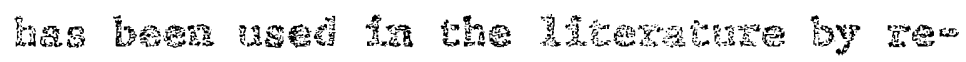

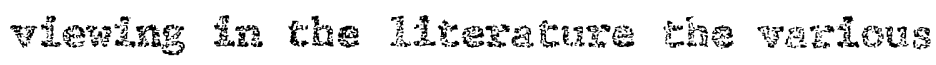

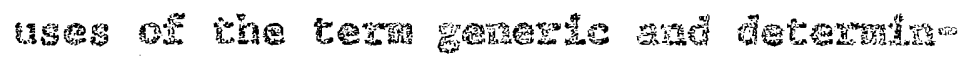

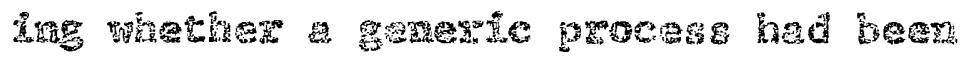

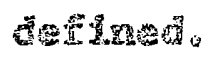

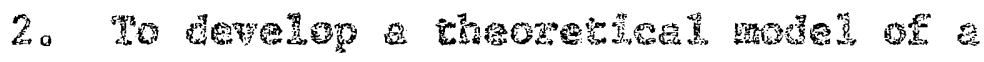

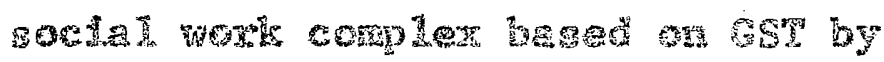

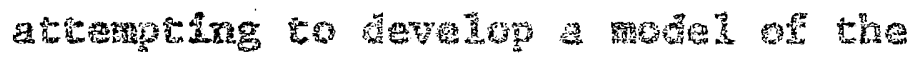

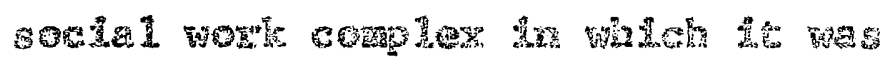

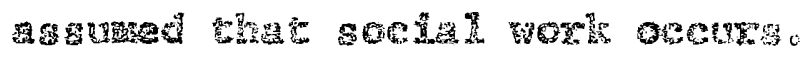

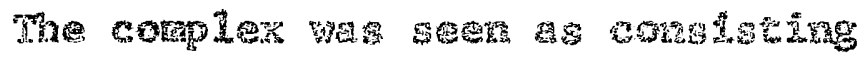

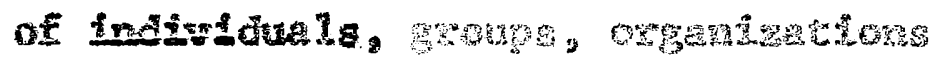
and the echurity.

3. To take the prellatasy stopg in

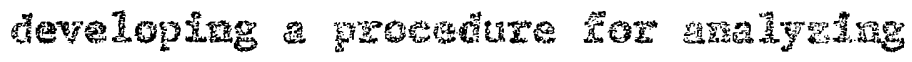
a case 1 in trats of CST.

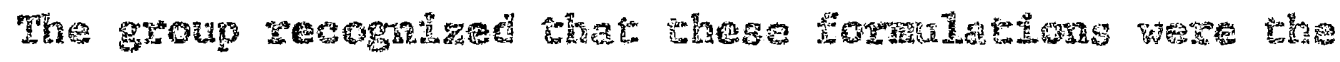

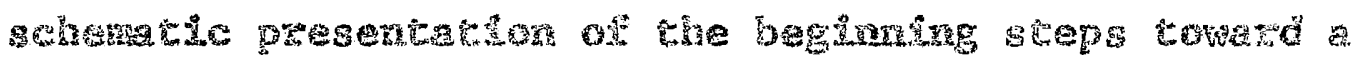

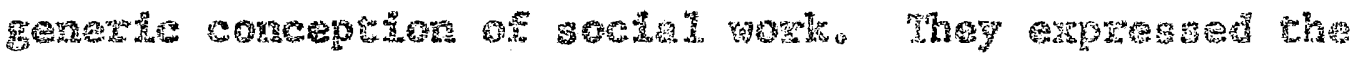

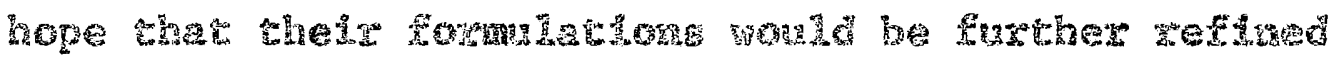
4. 


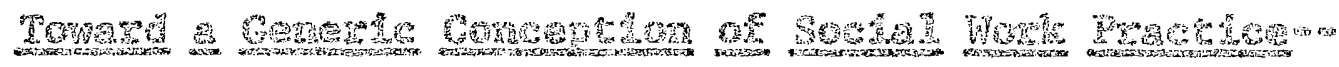
A Msthod of Araty

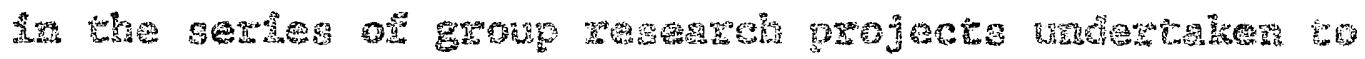

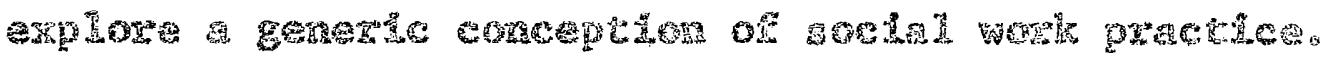

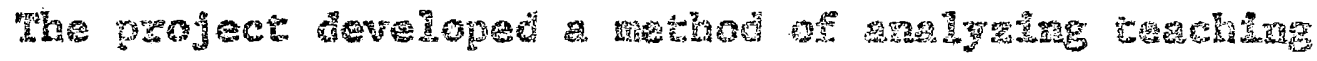
records in rexms of what the worker toos.

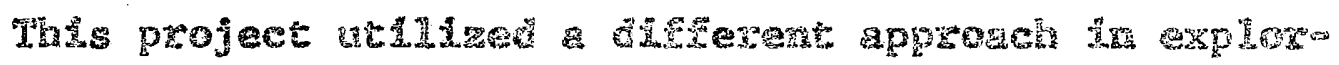

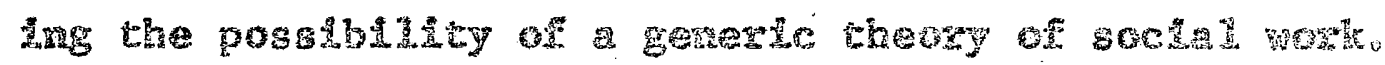

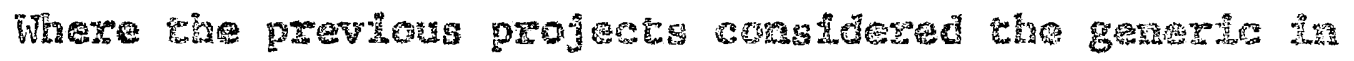

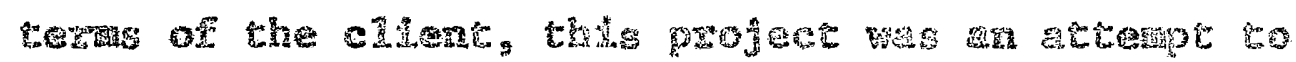

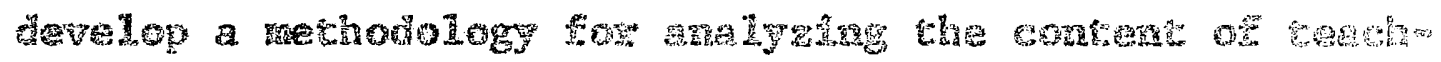
Hing records the terms of the practhroner.

The project and In case records that wers used to convey the cassworth,

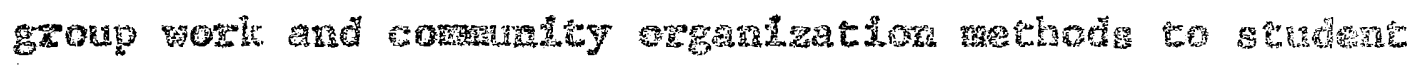
soetal workers. As had baen agggested in the 1959 projecs, Eheir dow th of ancerest of this projact held to the

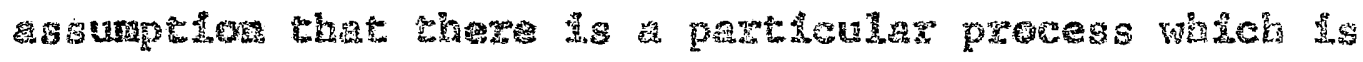
simflac whether the sochal worker is fravolved whth ind

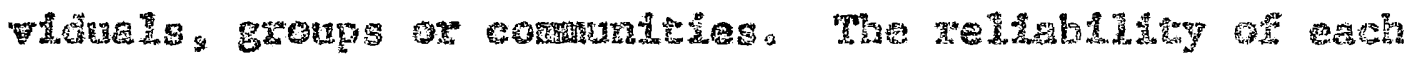
aspect of tandysis wis trested on a sump of the zecord.

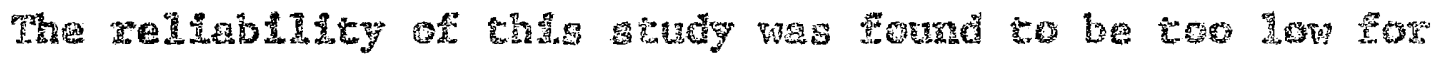

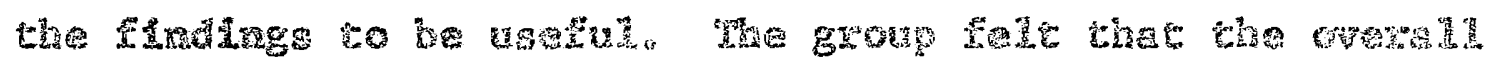

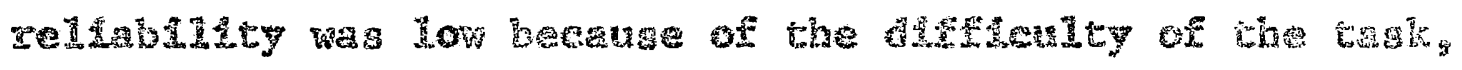

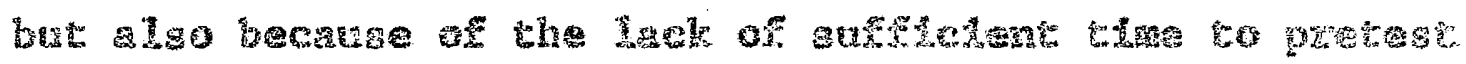
and dePlue the wethod adegterely. The metuze of the 
reworr

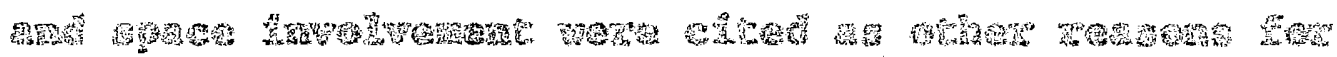

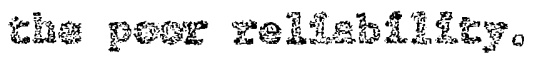

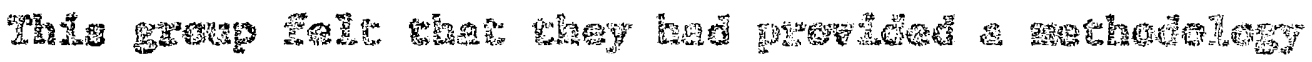
What

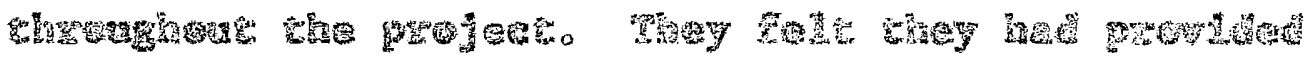

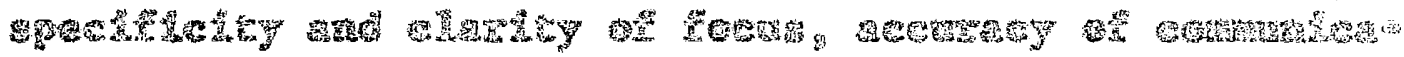

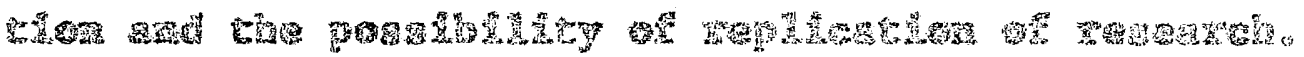
TH

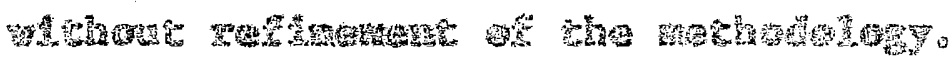

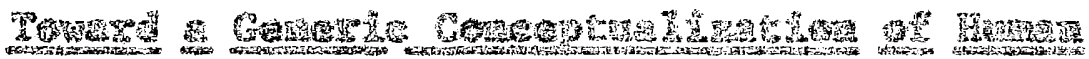

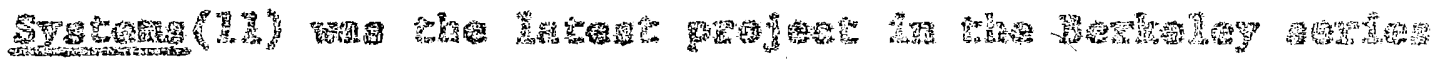

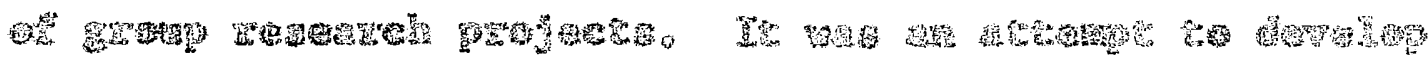

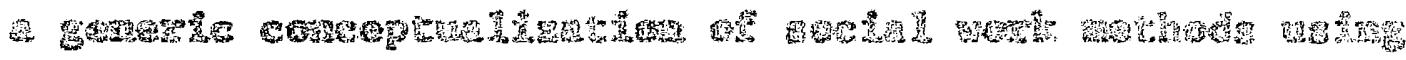

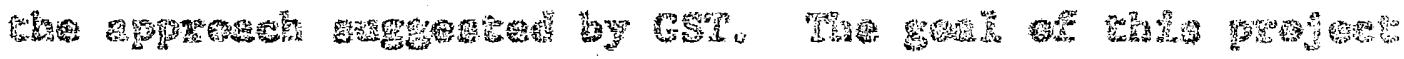

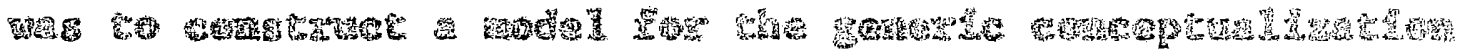

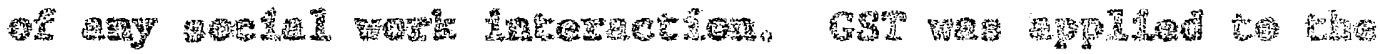

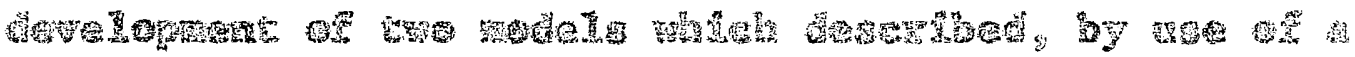

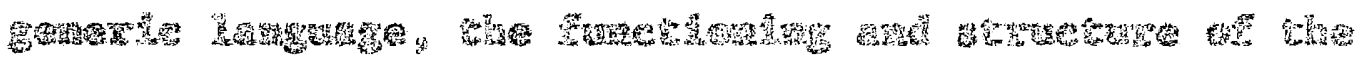

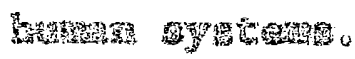

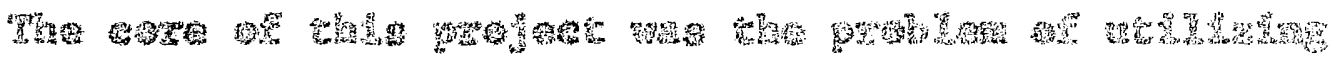

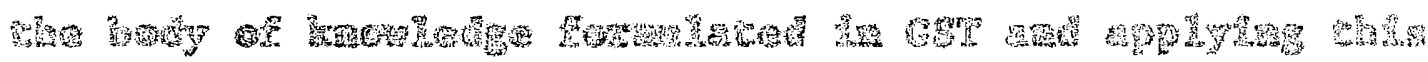

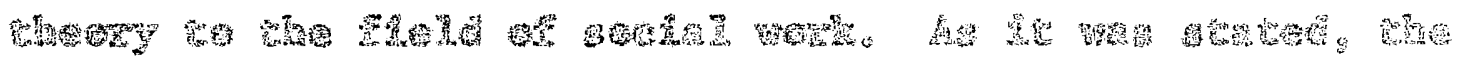
gryot

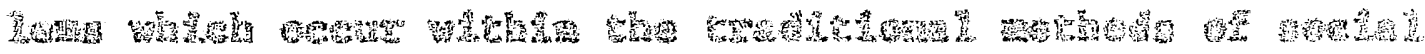

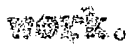




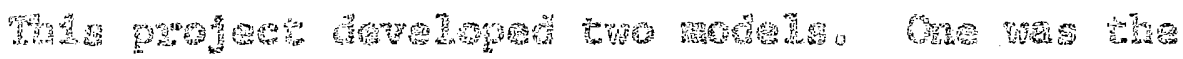
"5

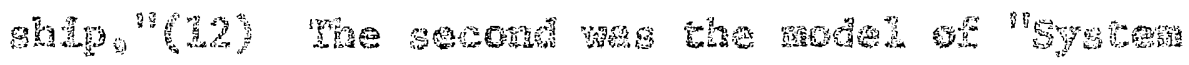
Hath

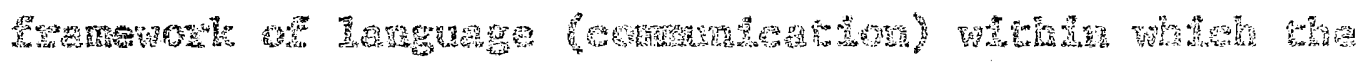

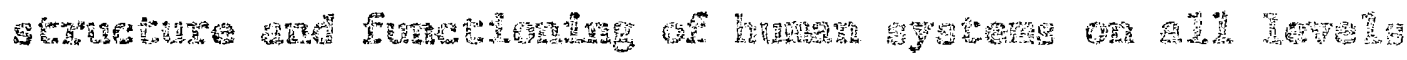

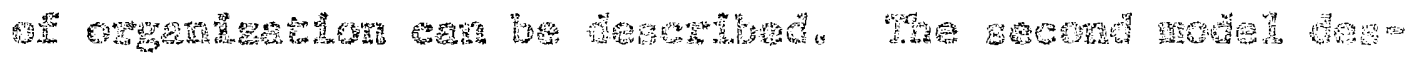

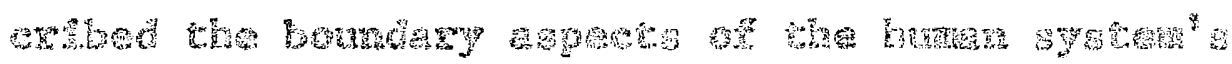

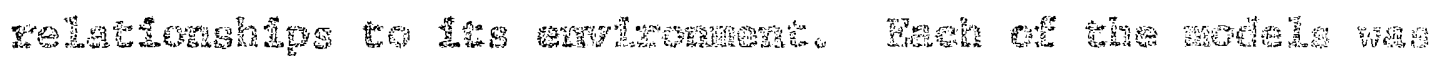

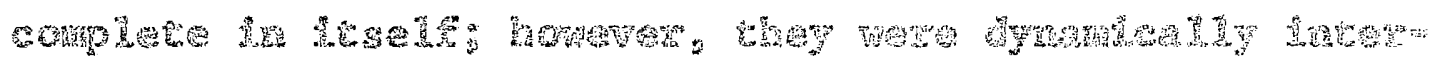

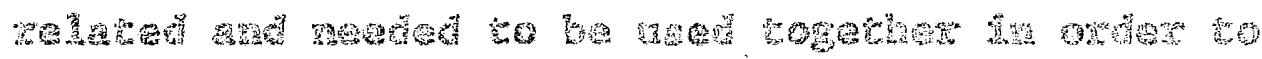

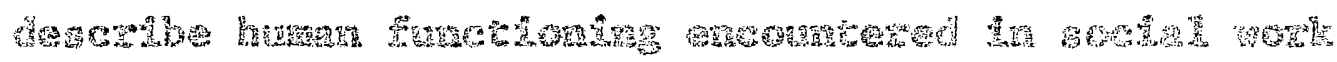
pratatede.

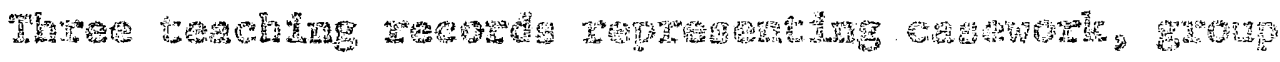

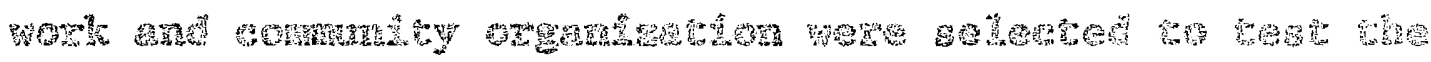

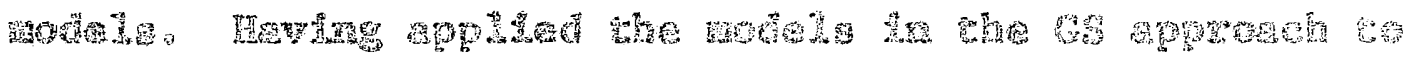

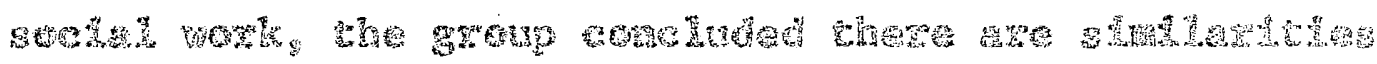

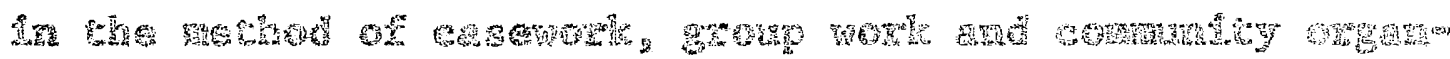

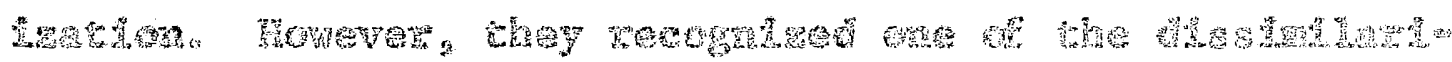

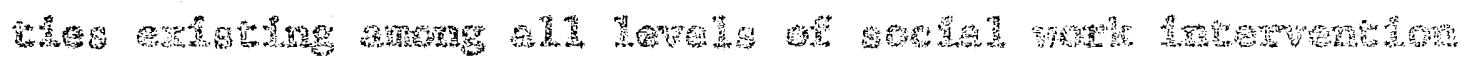

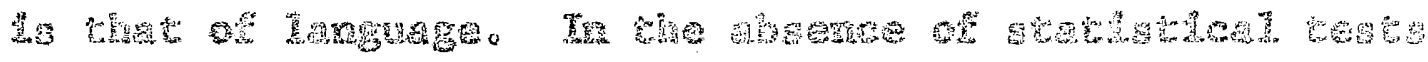

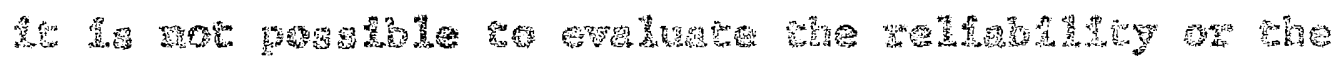

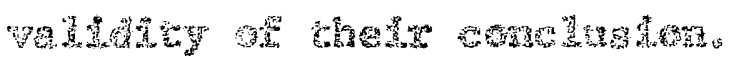

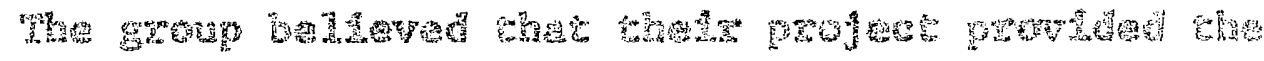

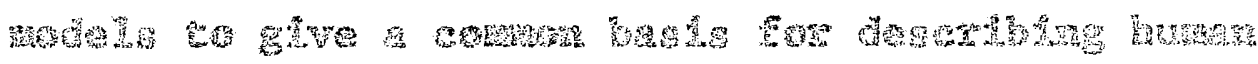




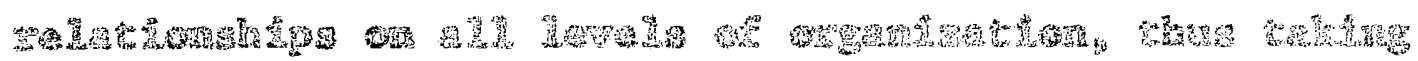
a w

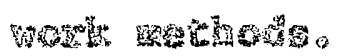

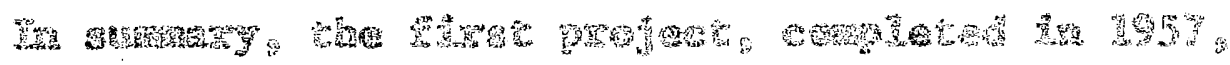

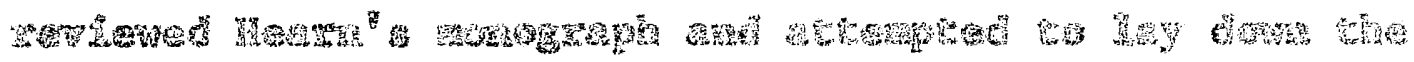
What 4.

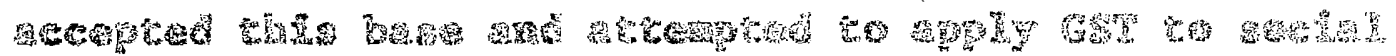

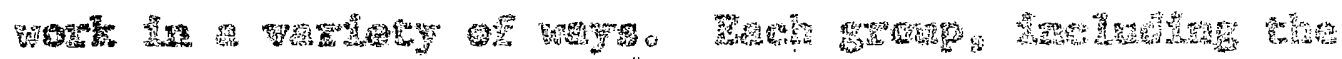

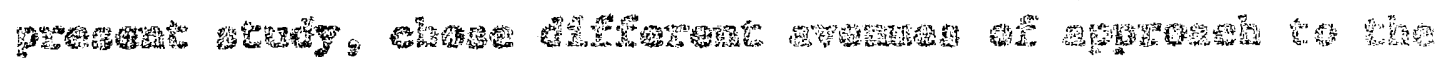
prob la

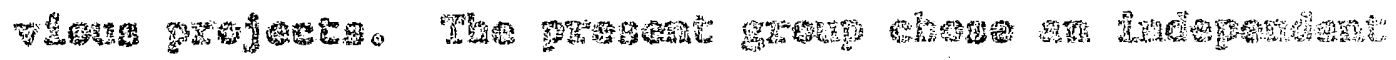

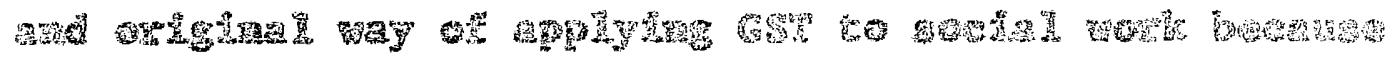
20 W

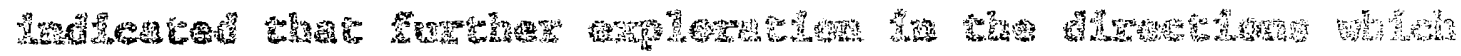

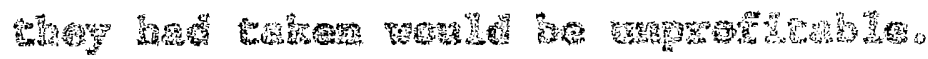

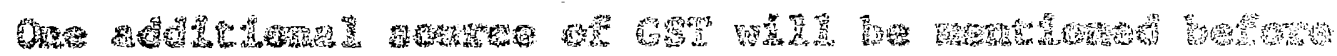

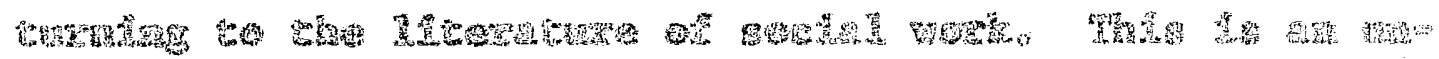
pagh

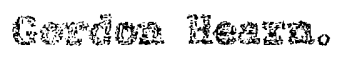

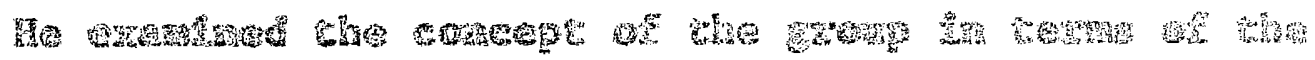

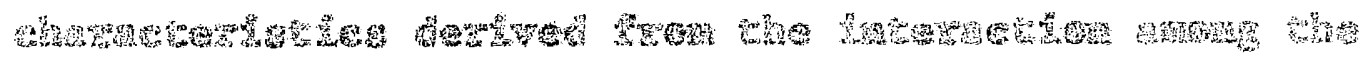

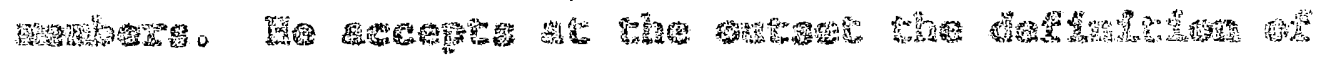

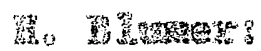

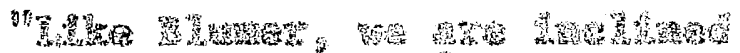

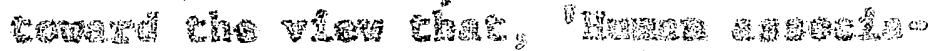

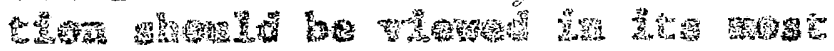




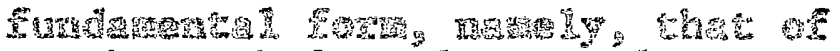

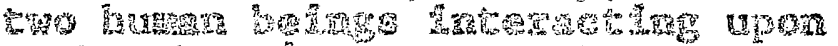

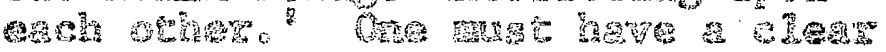

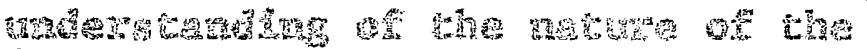

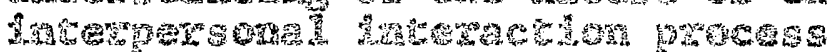

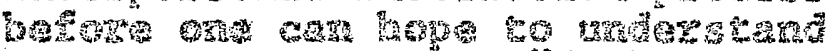
the nature of groups. "(

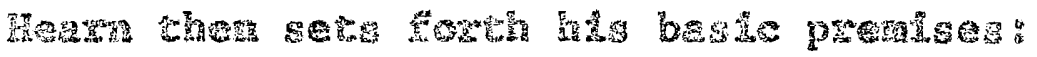

"rit: ondy valde way to scudy a frow 25

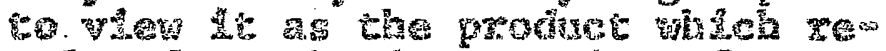
guts

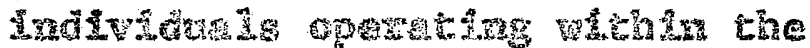

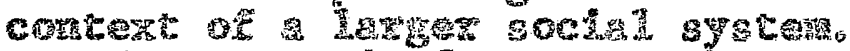
One toes not, Ix fact, see the grats

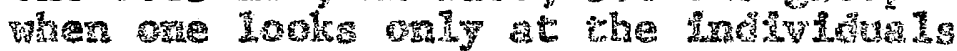

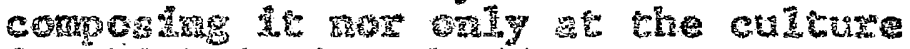

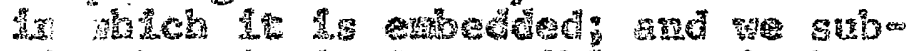

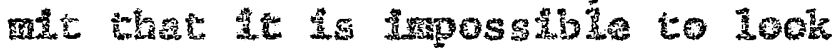

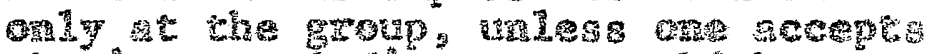

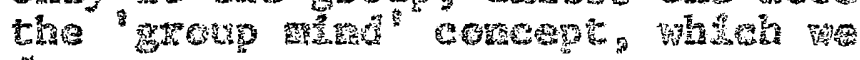
do sot.

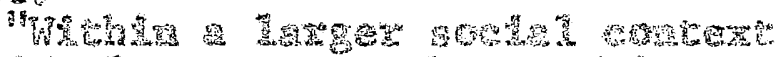
Mrditw' are" A

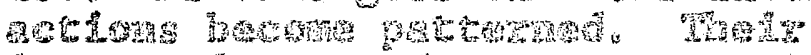

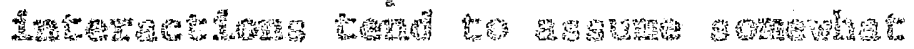

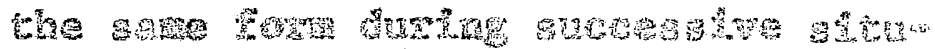

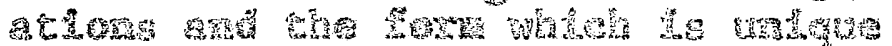

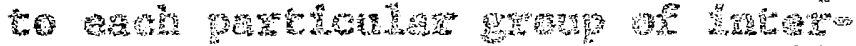

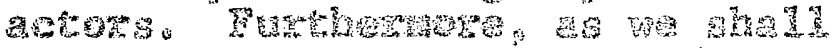

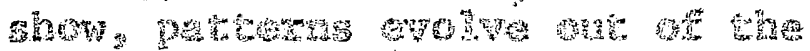

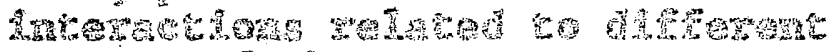

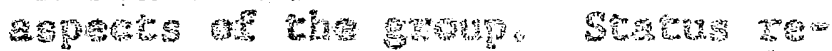

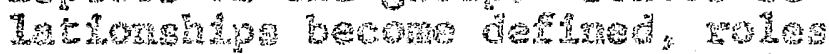

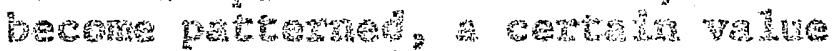

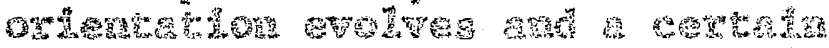

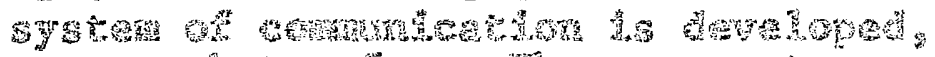

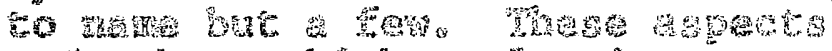

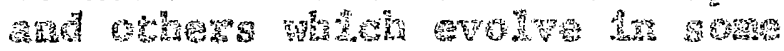

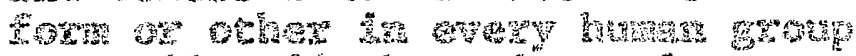

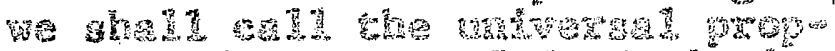

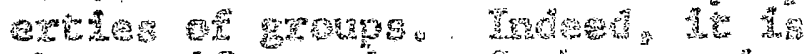

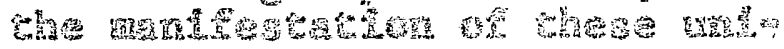

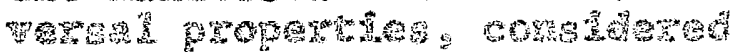

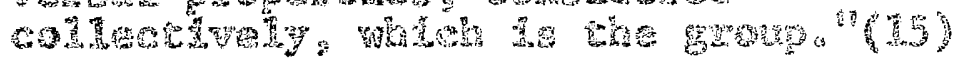




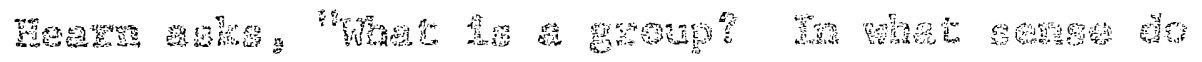

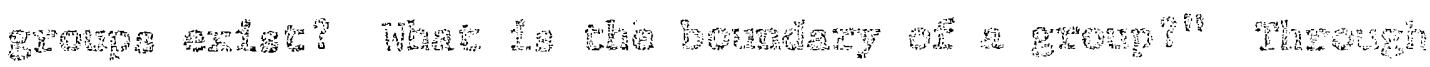

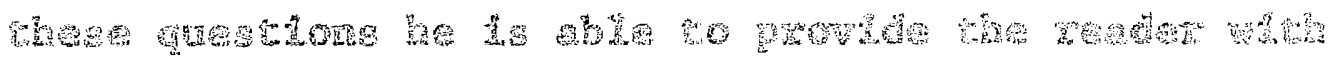
6.

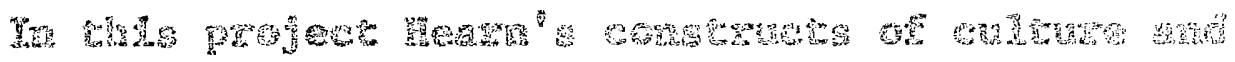

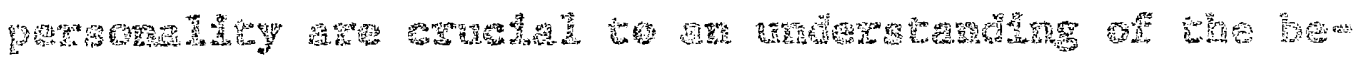

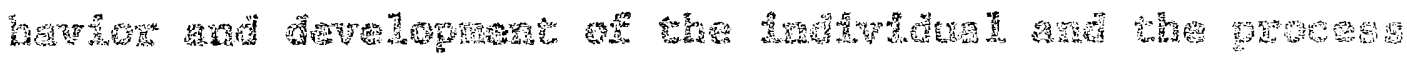

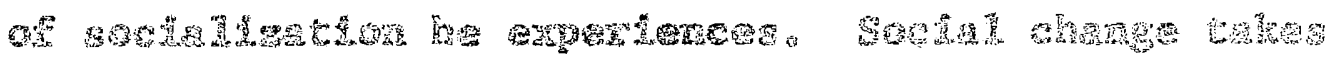

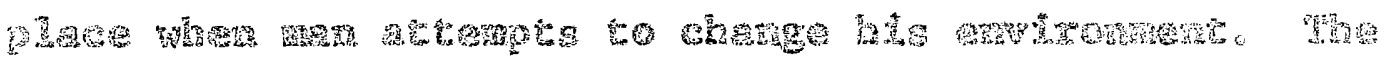

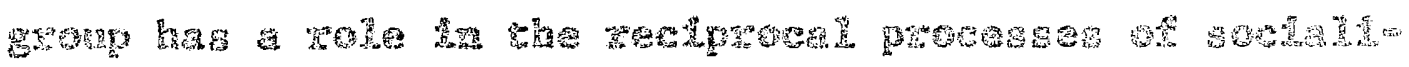

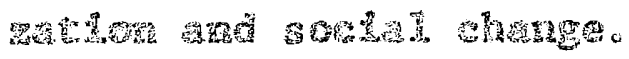

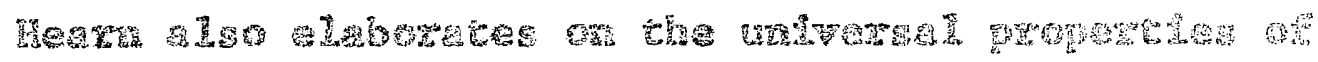

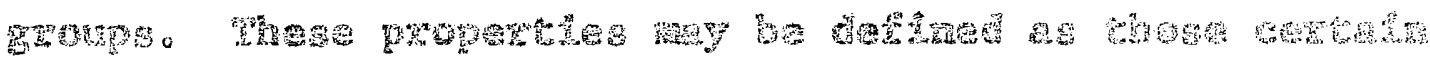

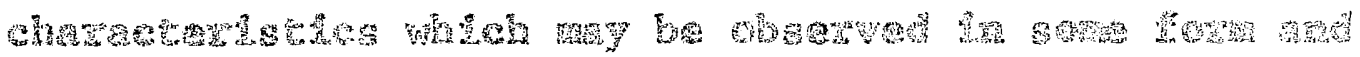

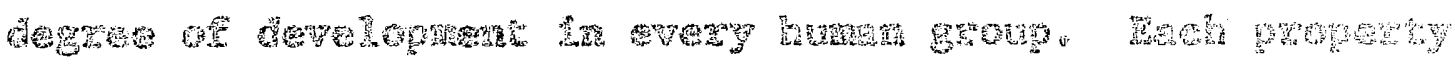
gestres a aped

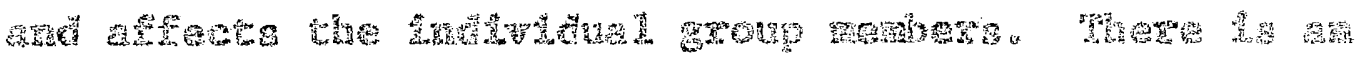

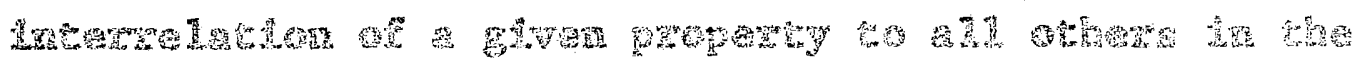

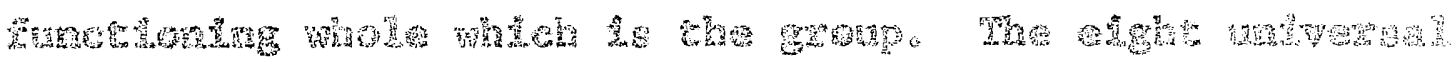

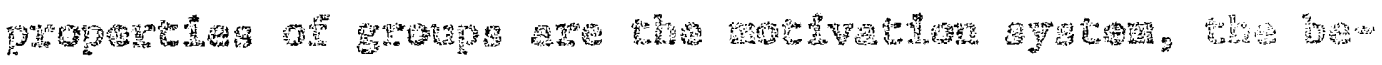

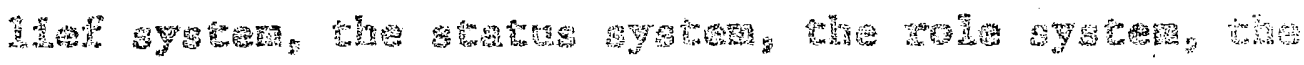
wet

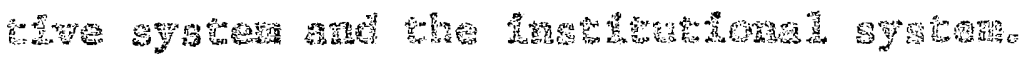

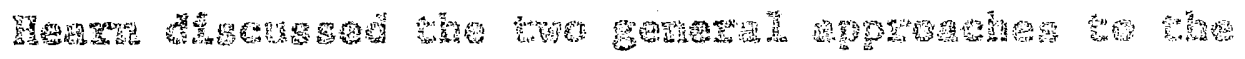

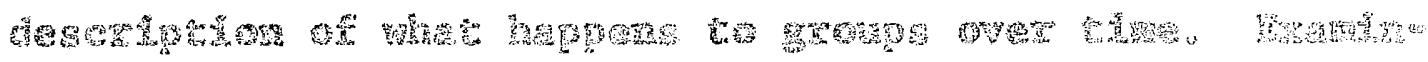

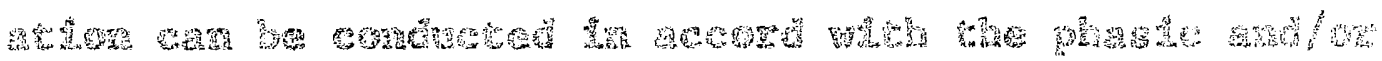




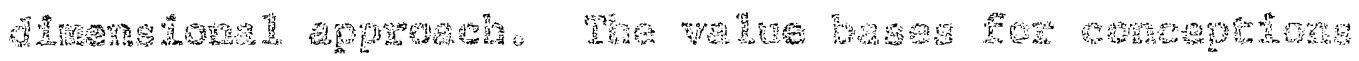

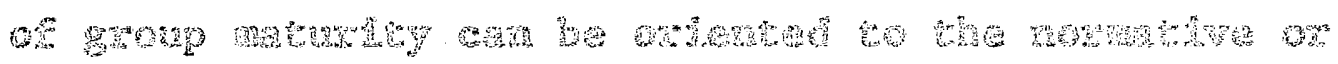

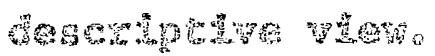

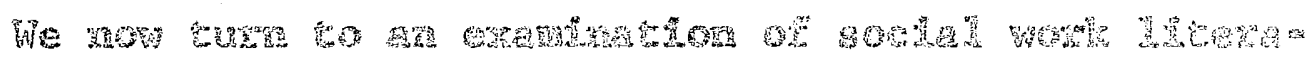

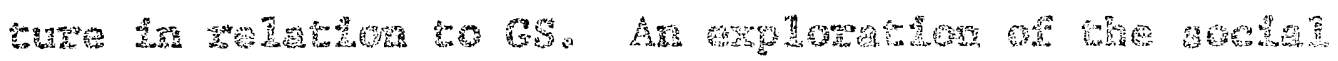

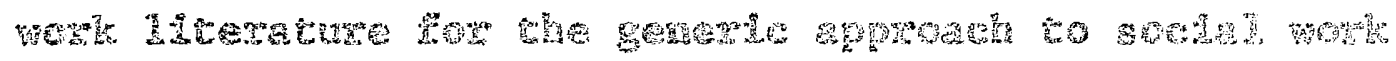

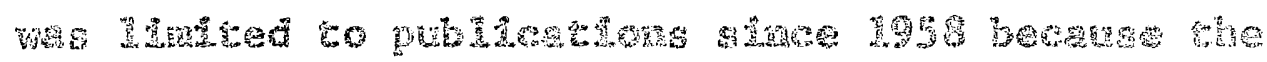

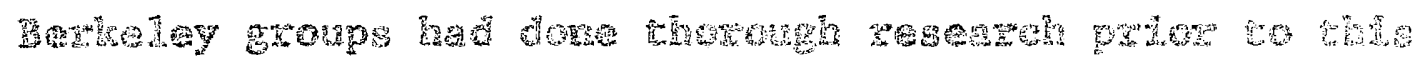

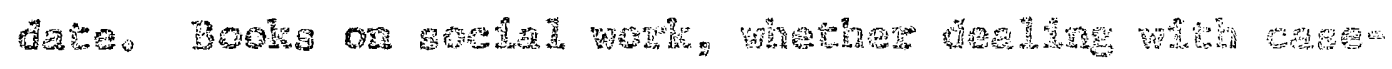

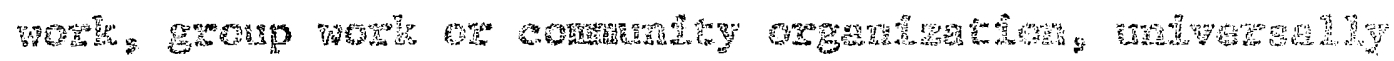

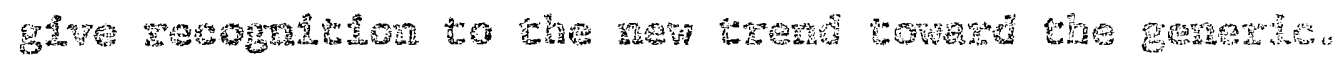

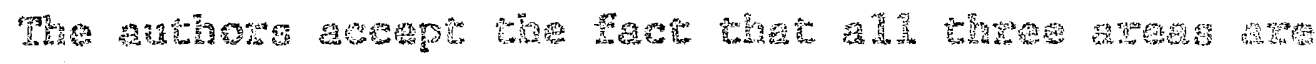

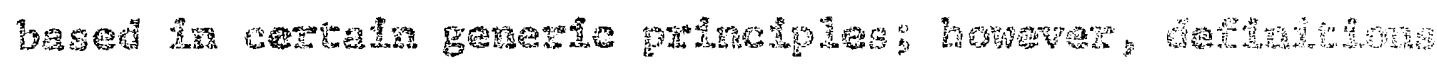

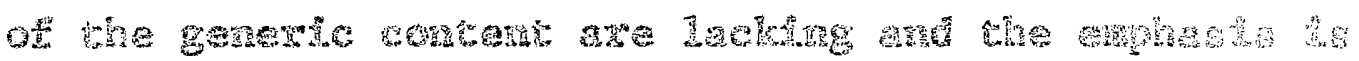

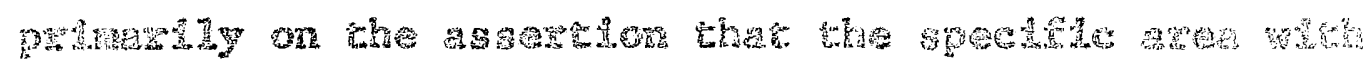

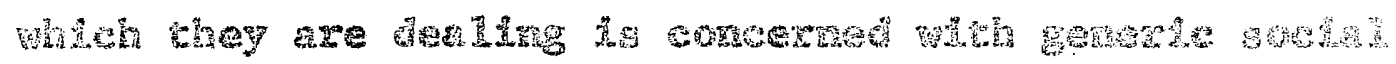
woti pranstples.

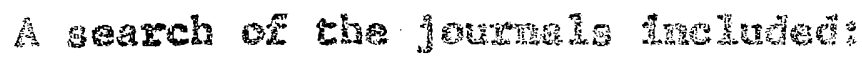

ChIld We 1 igres

The Gereng

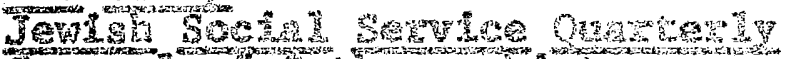

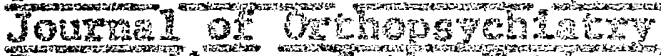

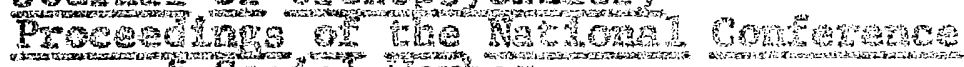

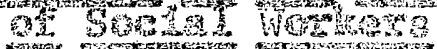

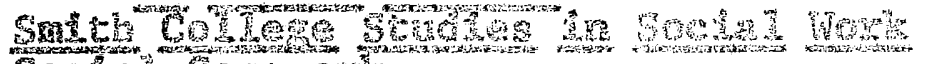

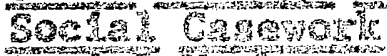

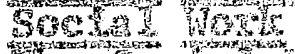

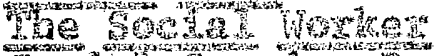

SBeza

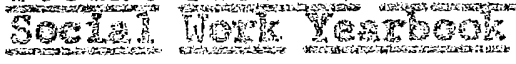

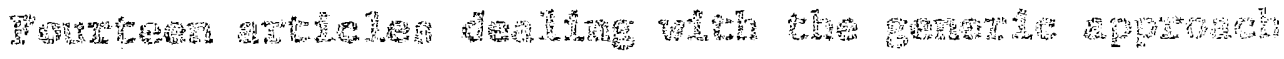

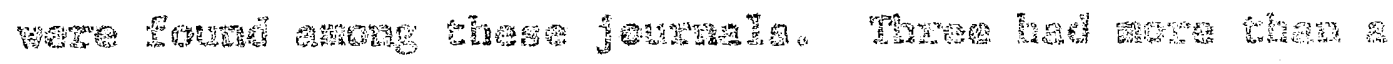




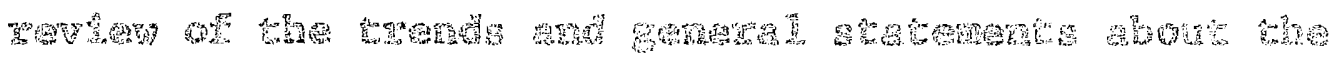
prown

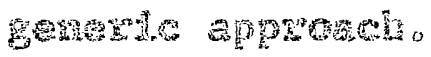

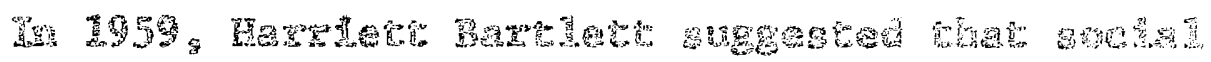

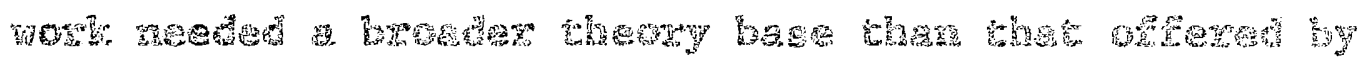

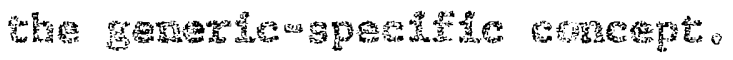

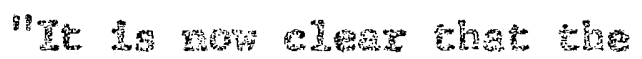
ACs

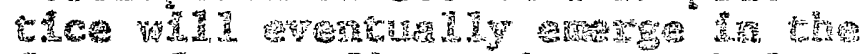

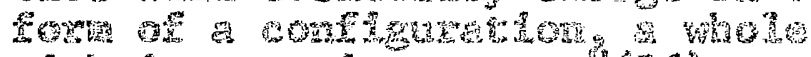

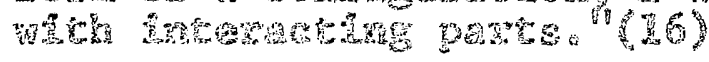

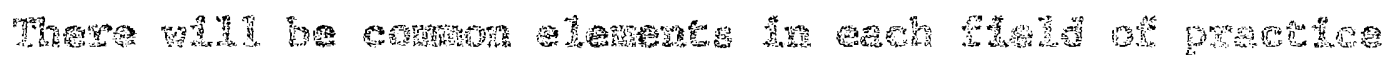

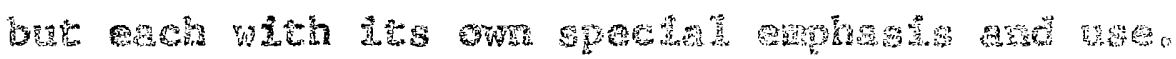

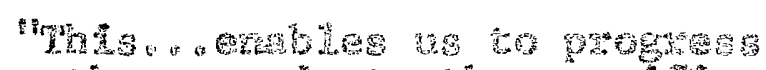

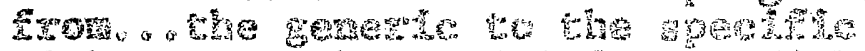

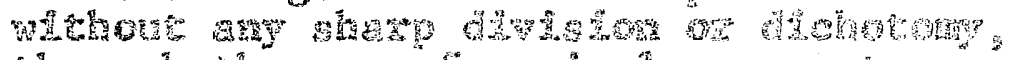

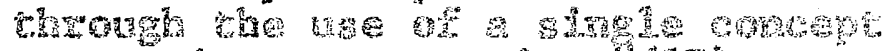

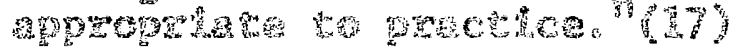

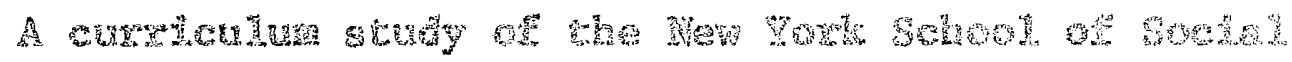

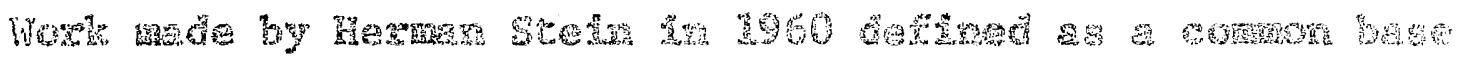

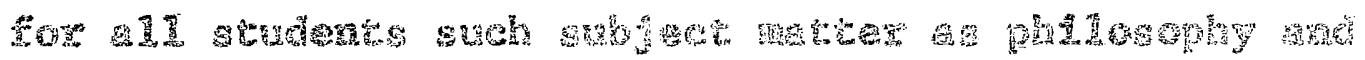

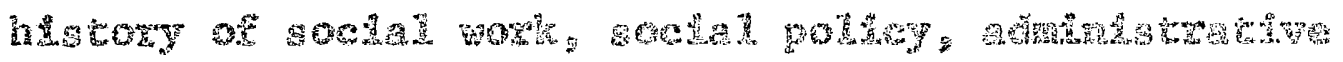

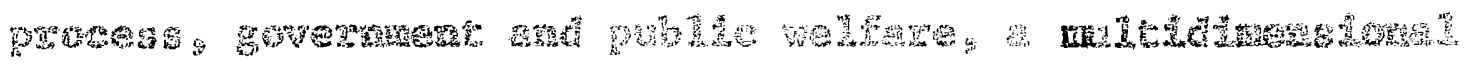

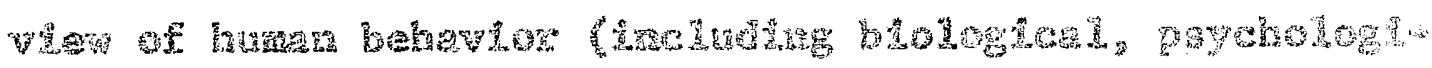

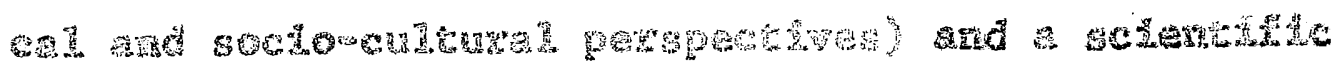

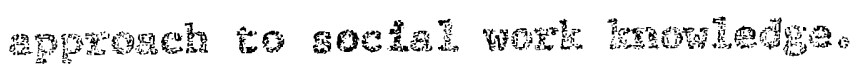

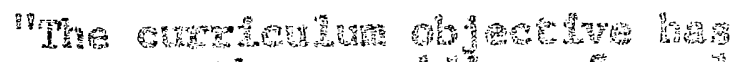

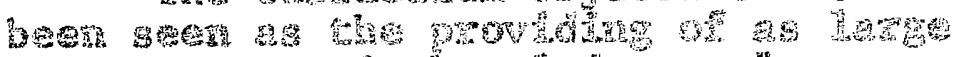

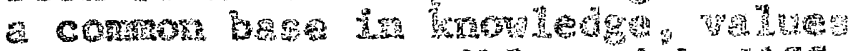

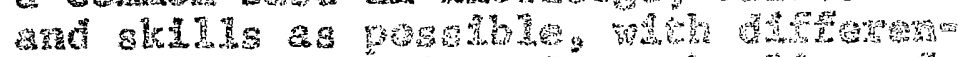

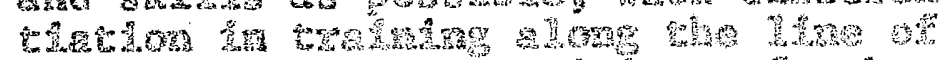
pratrirar

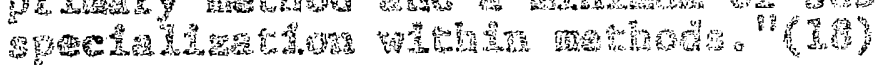




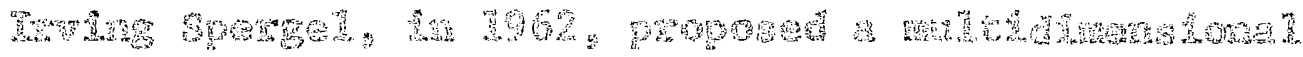

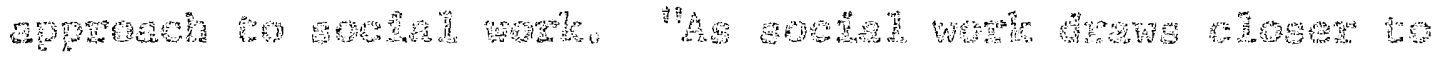

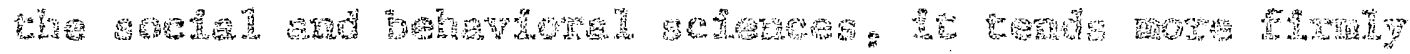

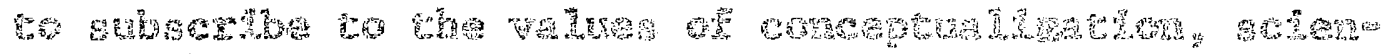

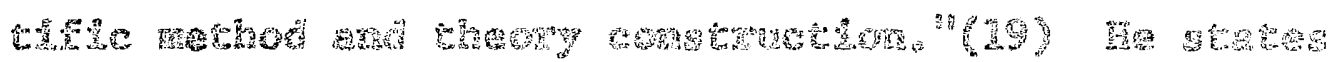

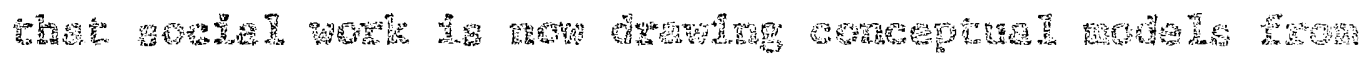

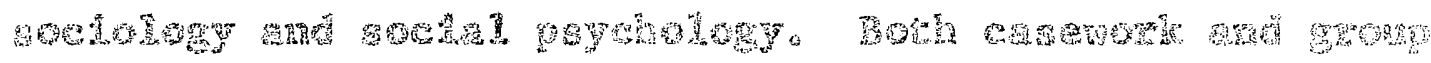

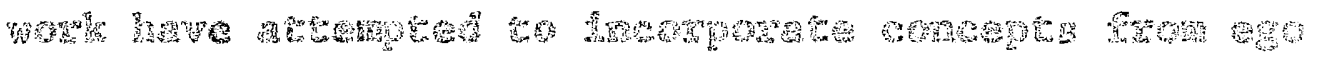
Po

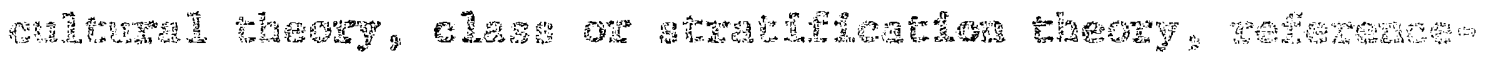

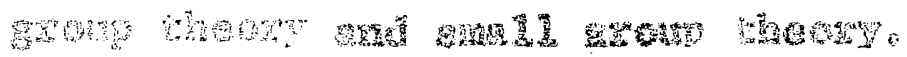

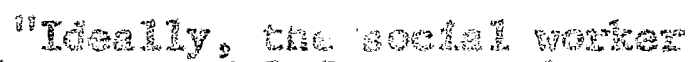

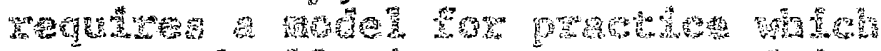

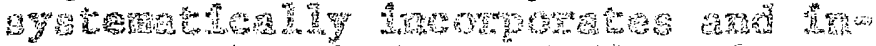

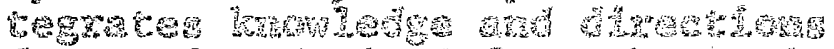

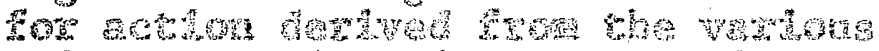

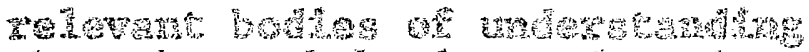

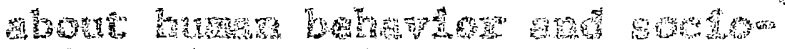
Q1 a d

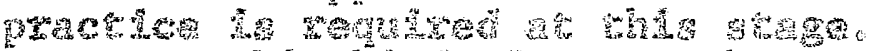
Wuws

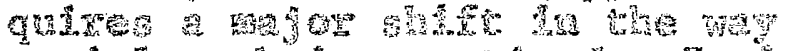

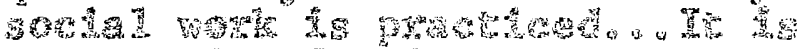

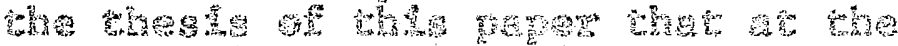

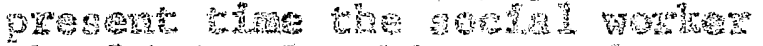

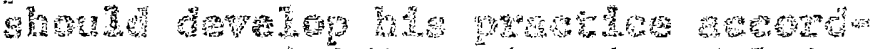

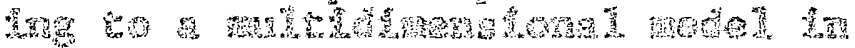

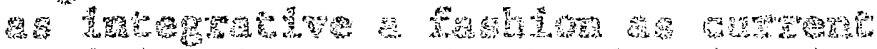

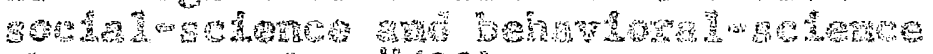

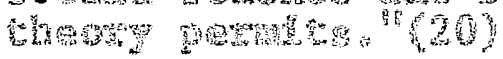

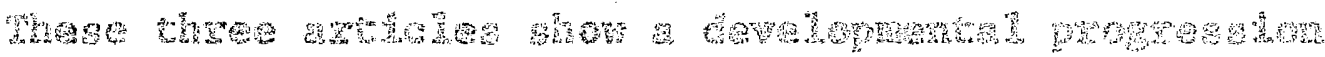

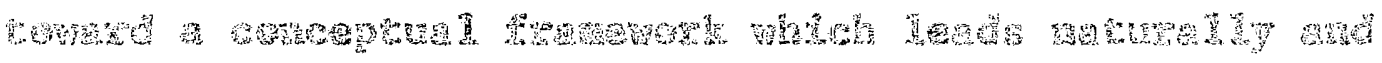

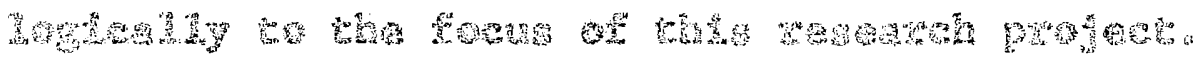

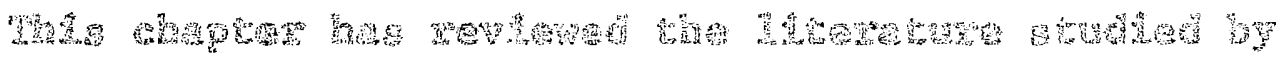

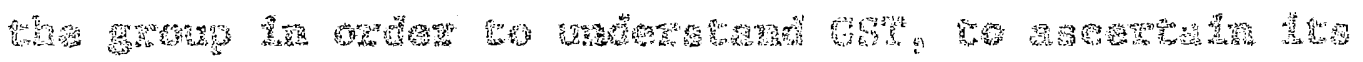




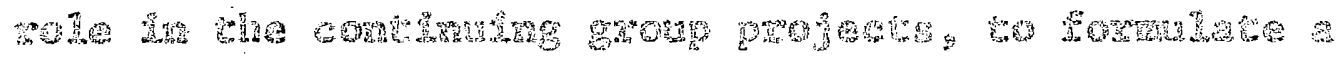

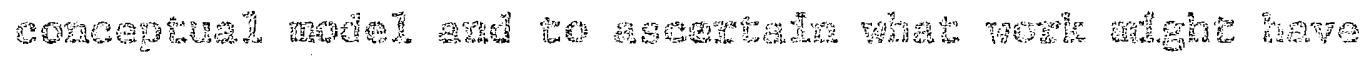

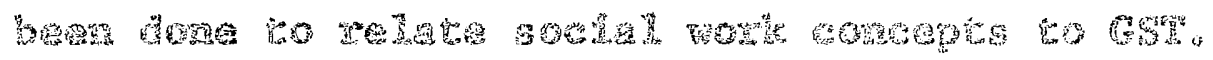

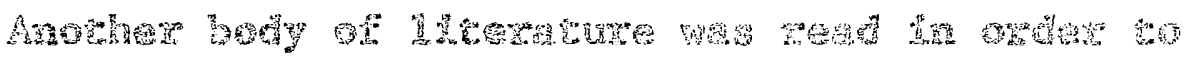

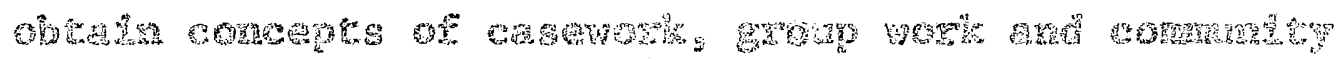

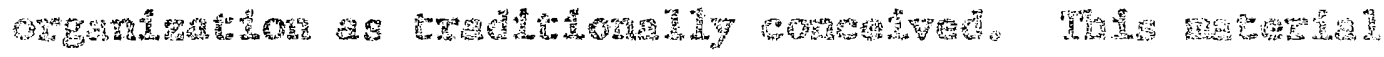

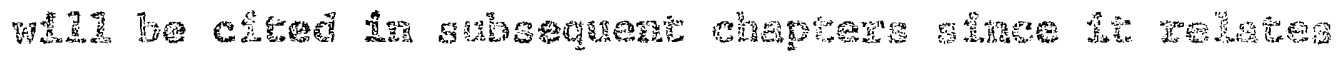

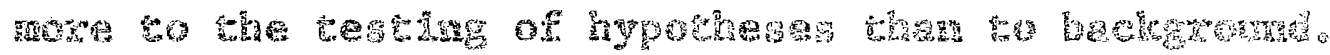

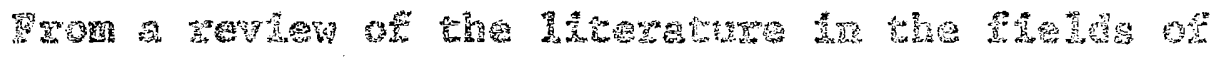

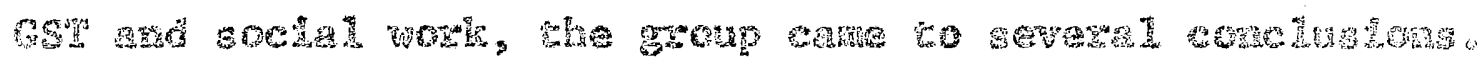

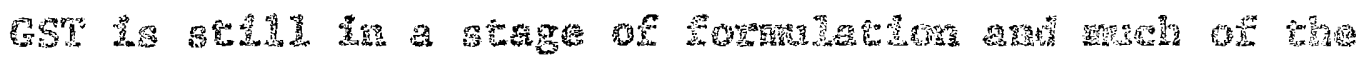

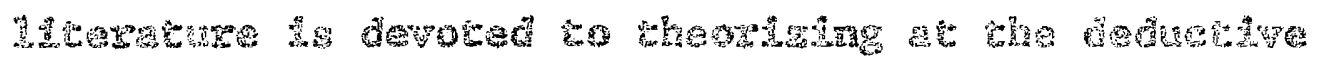

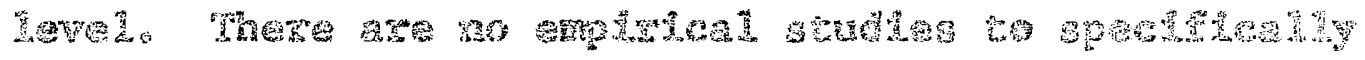

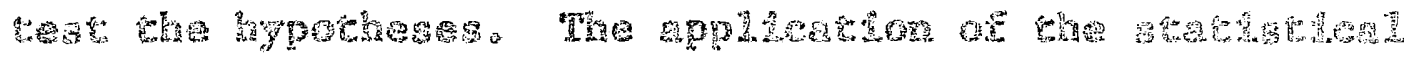

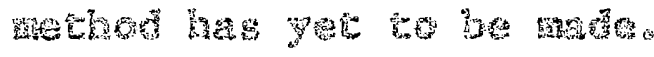

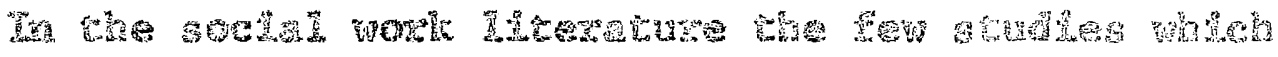

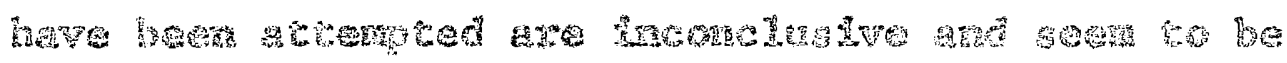

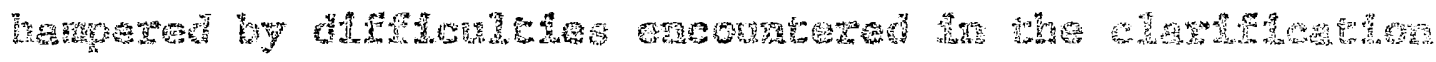

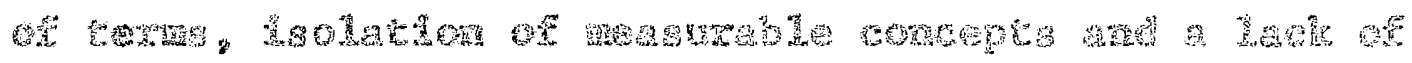

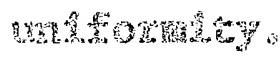

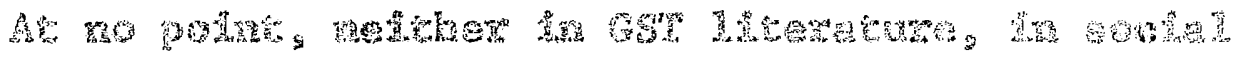

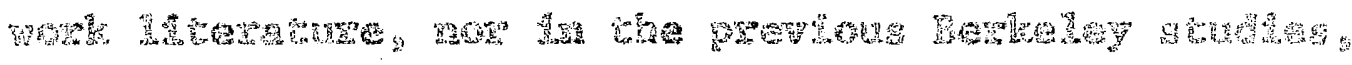

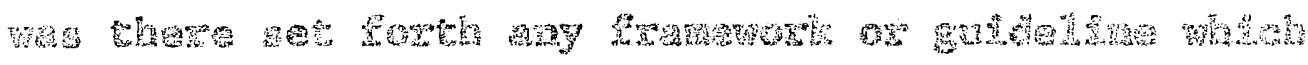

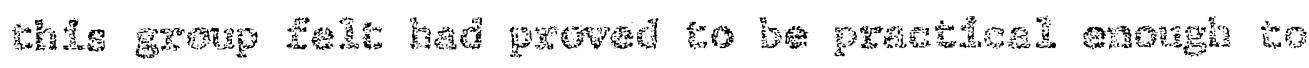

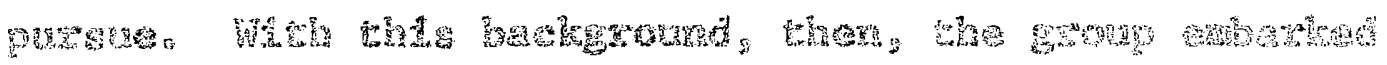

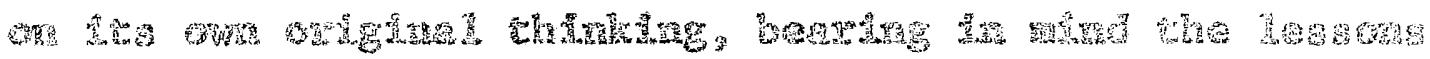




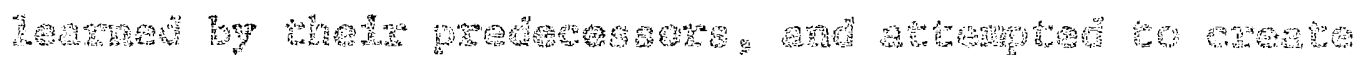

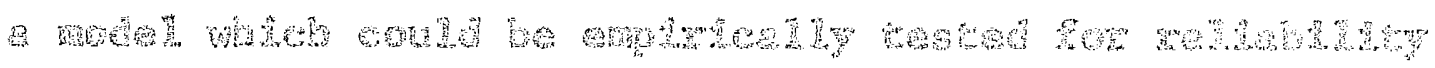

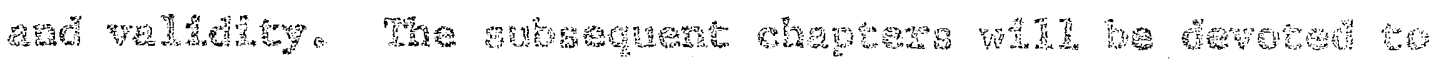

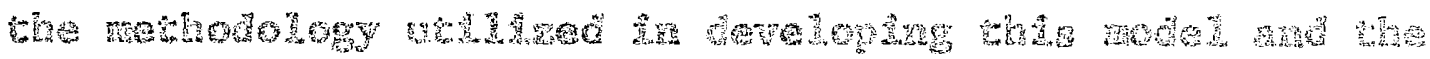

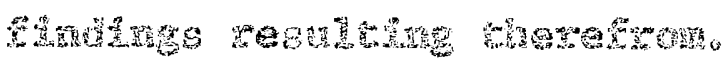


Mgers?

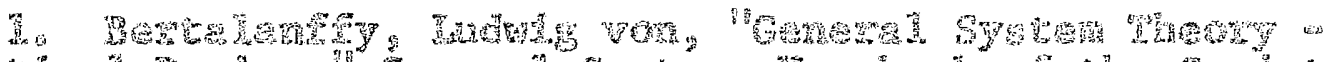

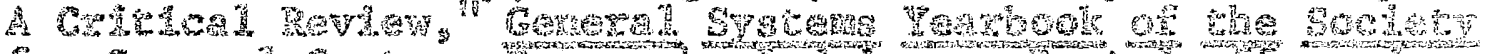

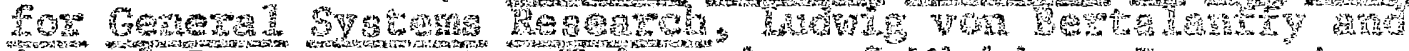

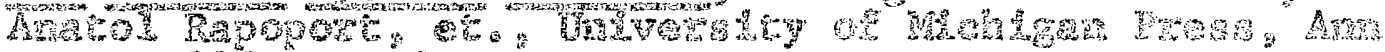

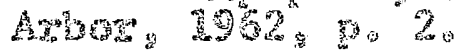

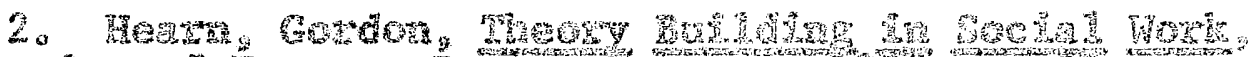

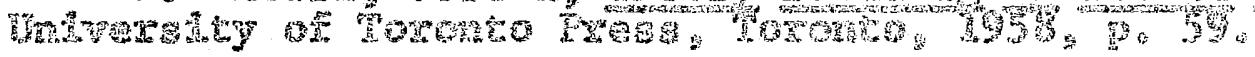

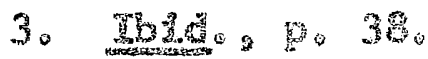

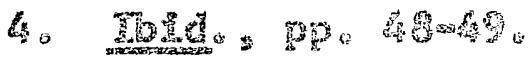

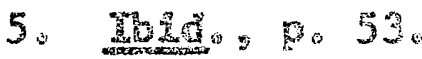

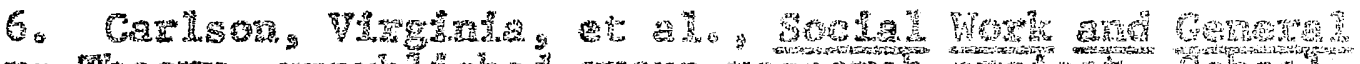

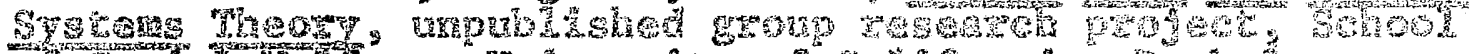

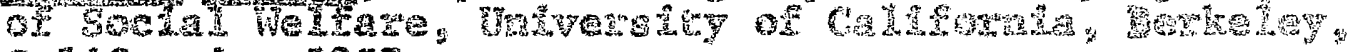
Ca110 0rata: 1957 .

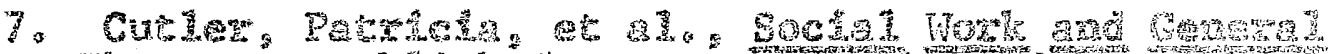

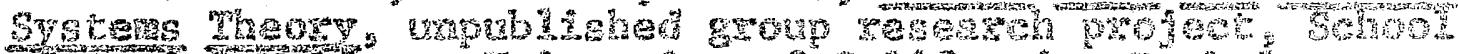

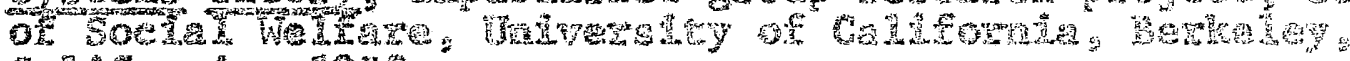

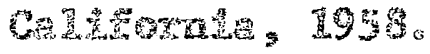

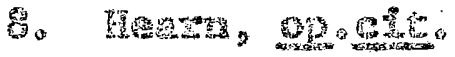

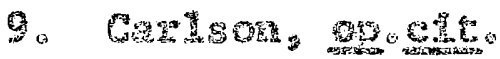

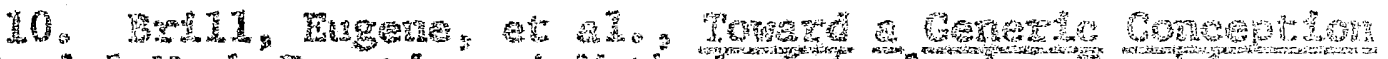

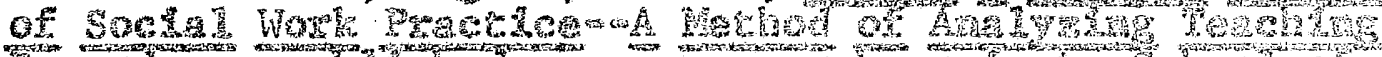

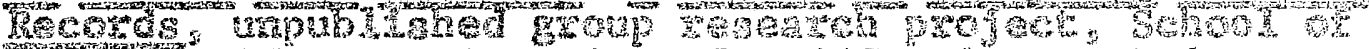

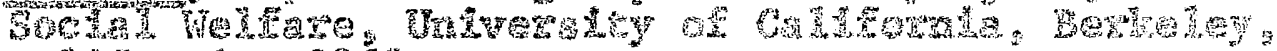
Cang

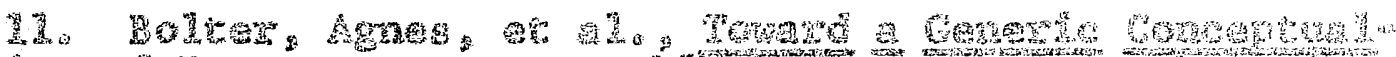

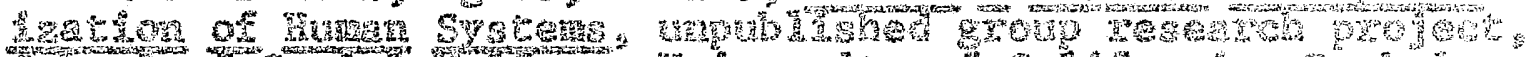

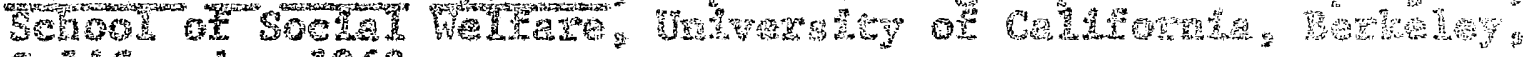

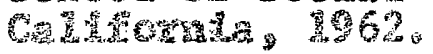

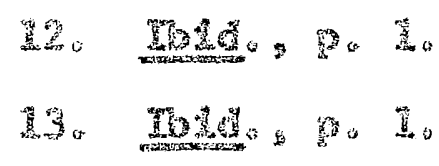

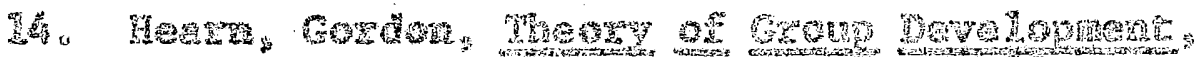

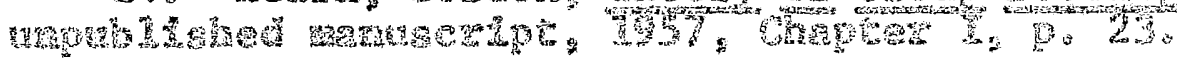




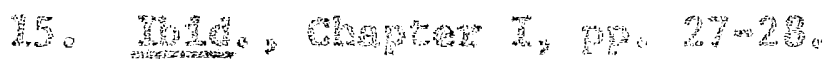

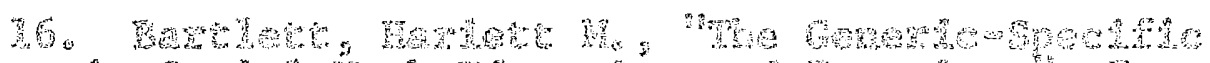

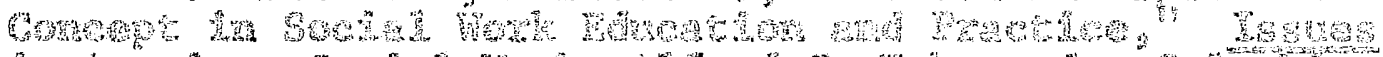

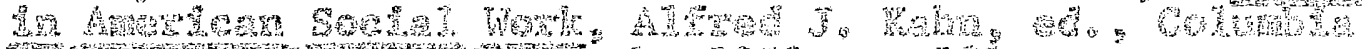

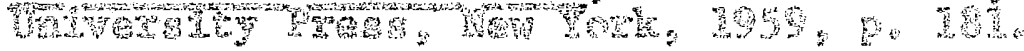

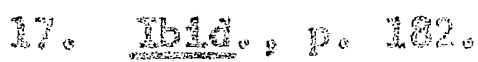

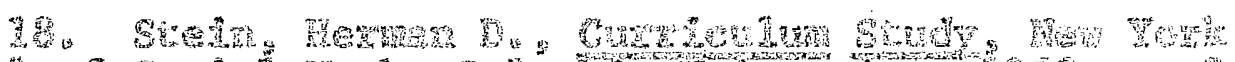

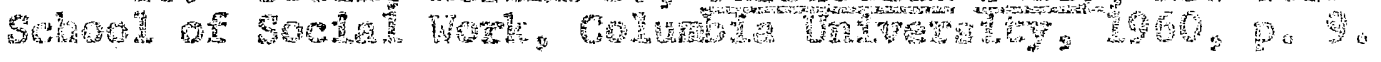

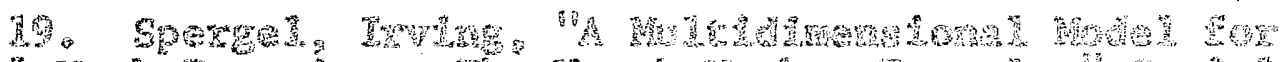

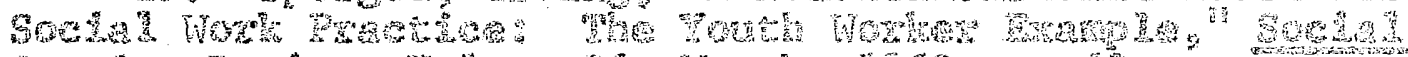
Benas

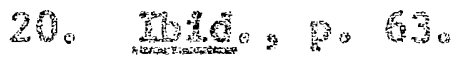




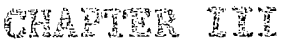

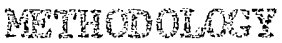

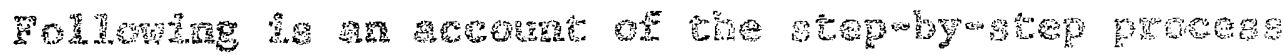

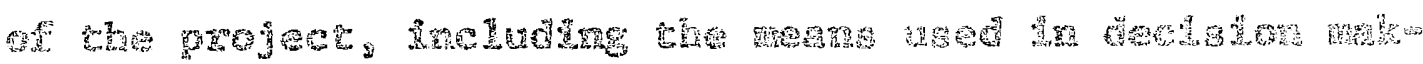

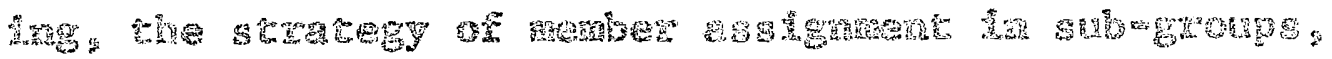

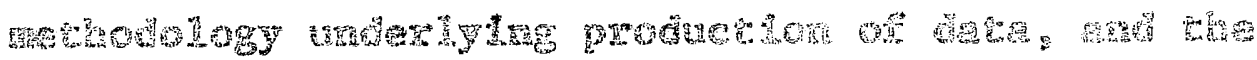

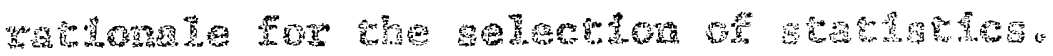

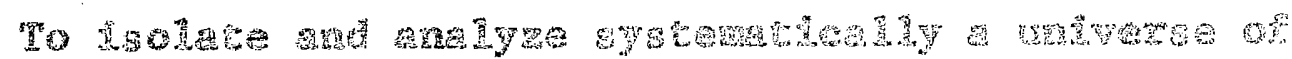

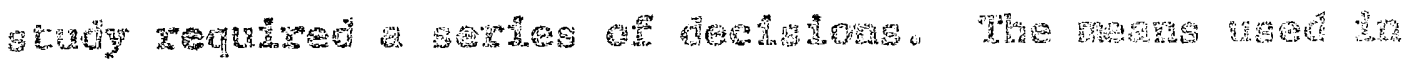

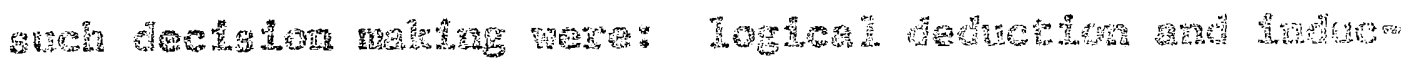

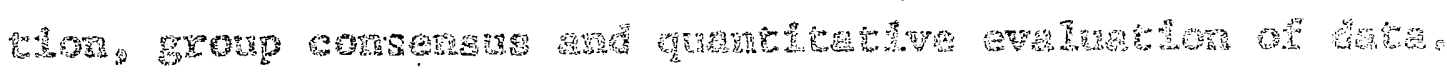

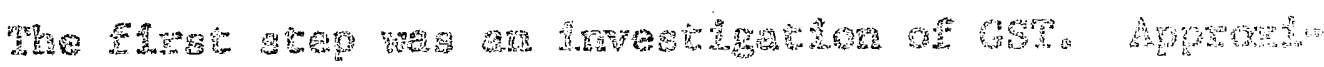

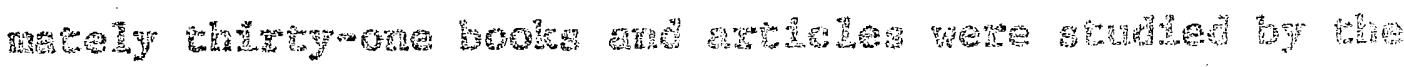

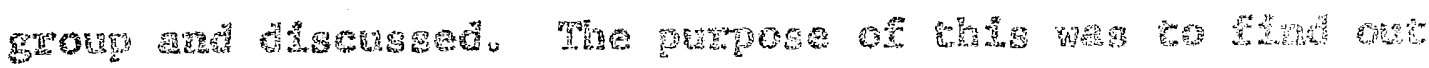

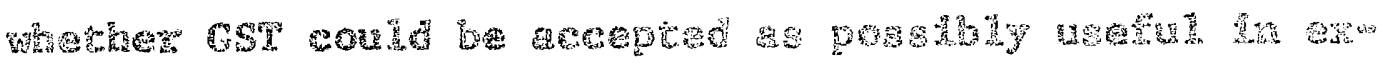

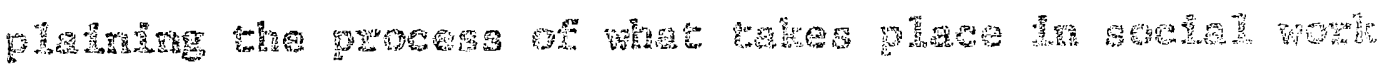
prasande

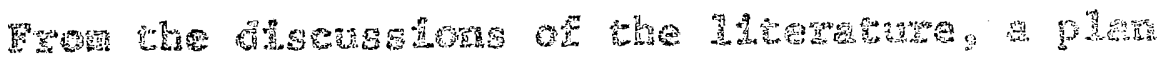

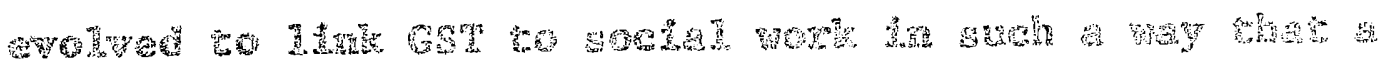

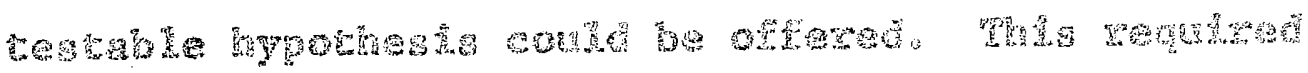

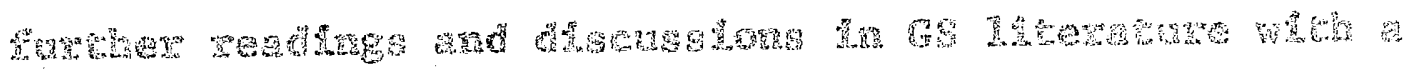

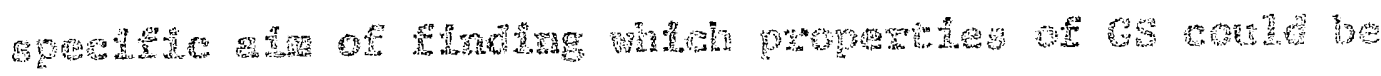

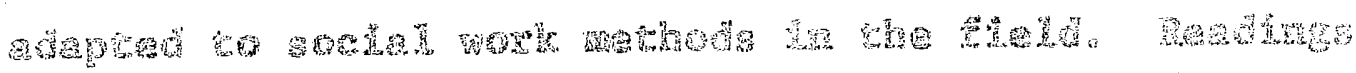




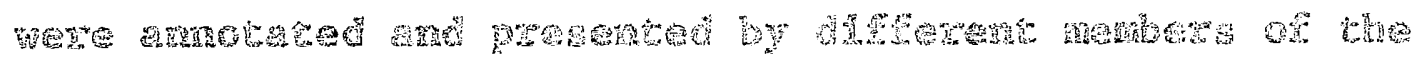

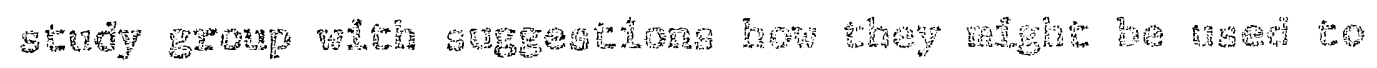

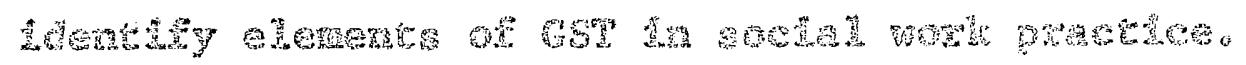

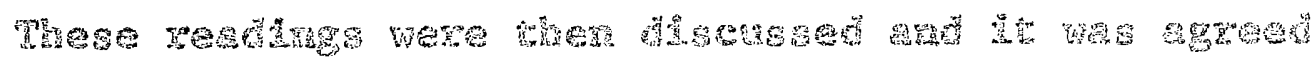

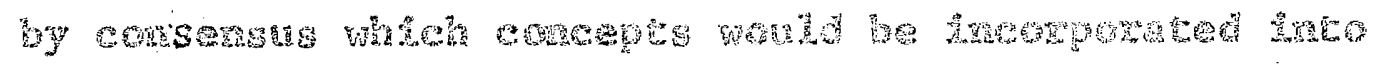

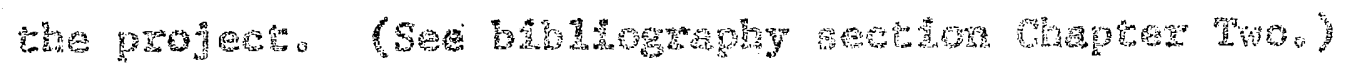

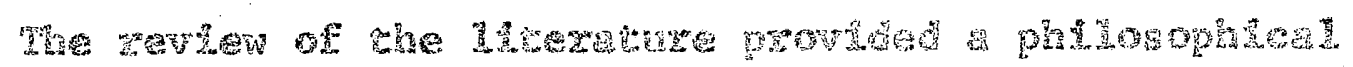

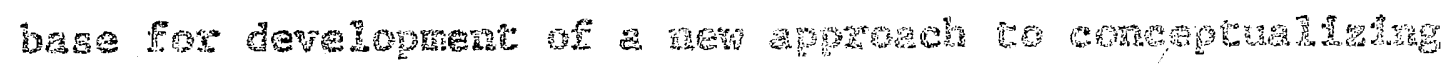
socts: Hork

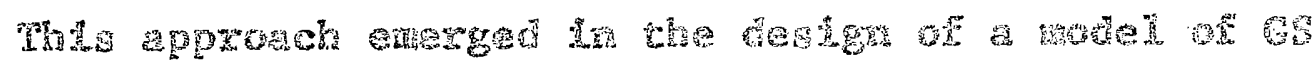

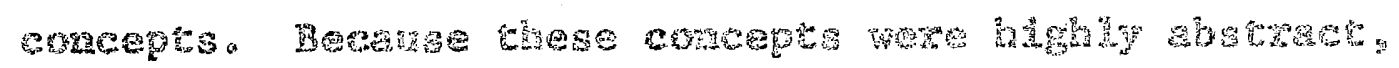

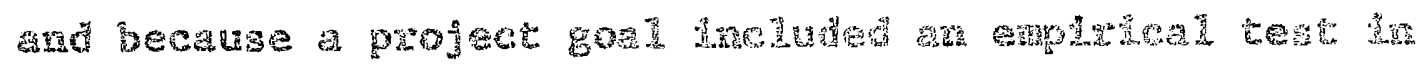

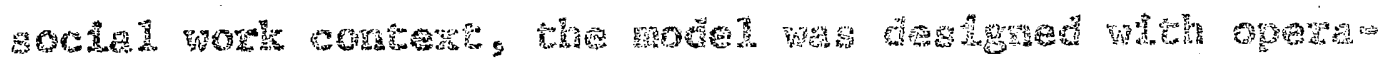
Ehonac ute

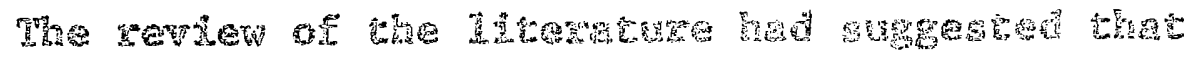

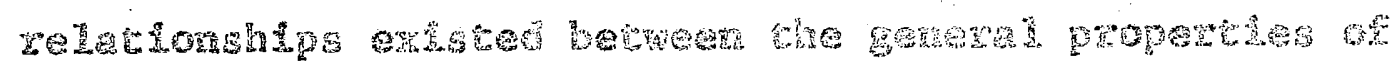

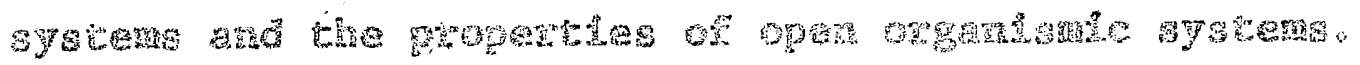

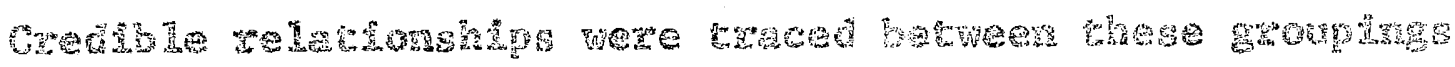

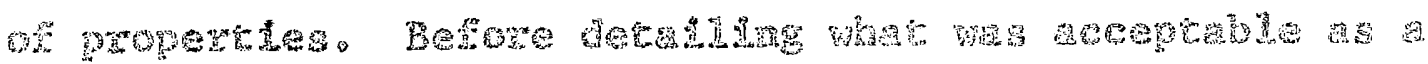

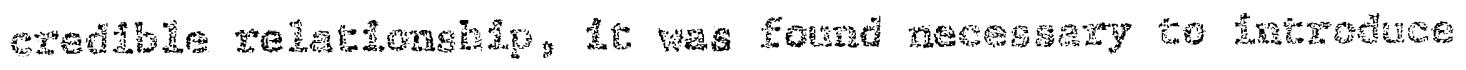

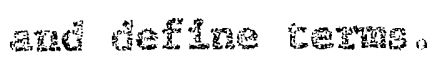

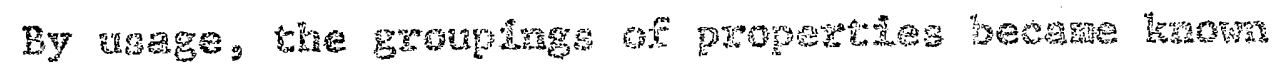

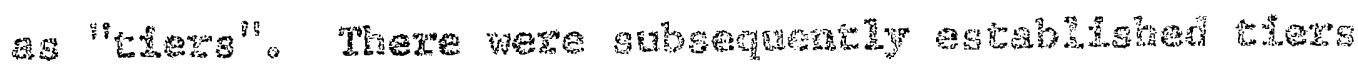

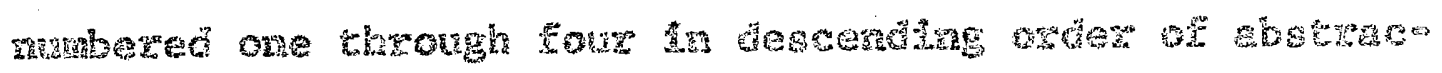
Hor. 


\begin{tabular}{|c|c|c|c|}
\hline 篔 & 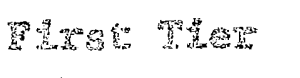 & $\Leftrightarrow$ & 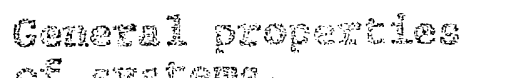 \\
\hline 䉴。 & Secored $\mathrm{ardes}$ & $\infty$ & 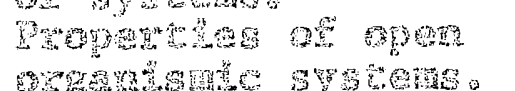 \\
\hline STa & The & $\therefore$ & 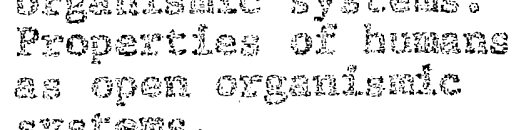 \\
\hline$V_{0}$ & Tonseth The & $\Leftrightarrow$ & 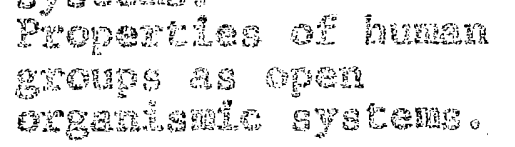 \\
\hline
\end{tabular}

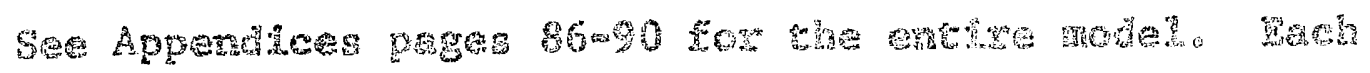

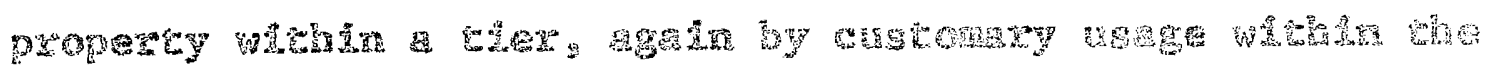

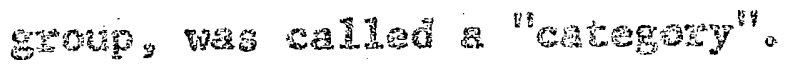

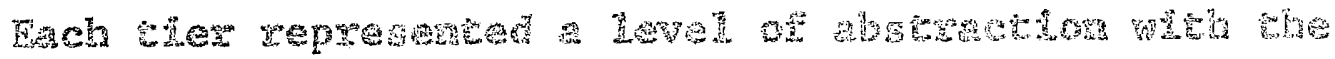

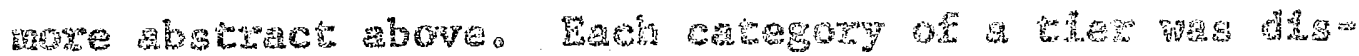

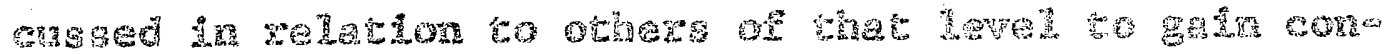

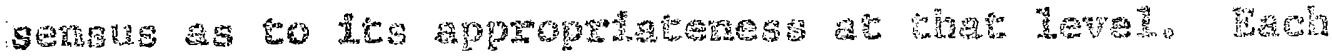

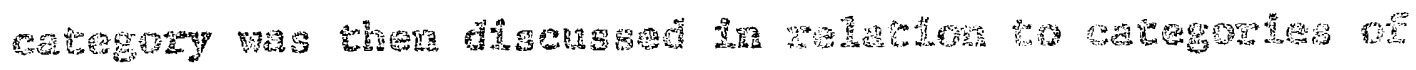

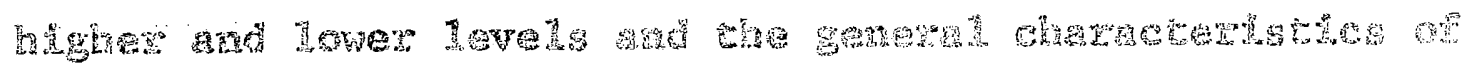

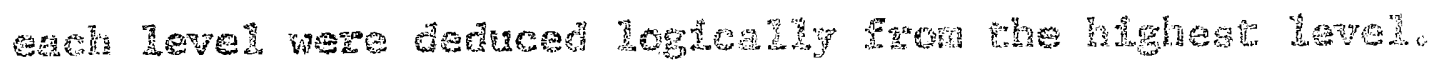

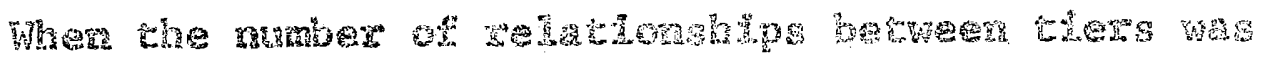
tow greet for logked and Was 8 s. We Log Ion.

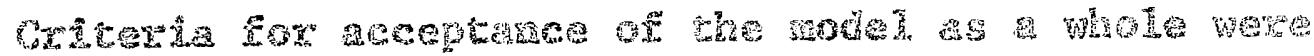
For,

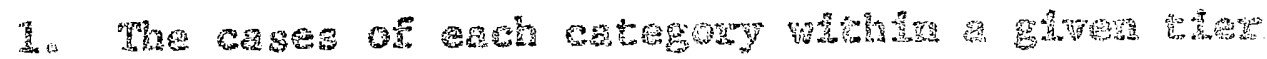

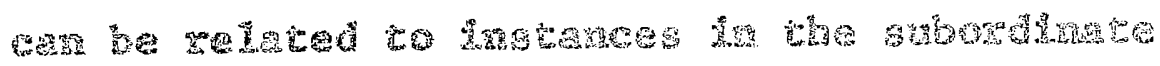

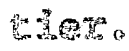




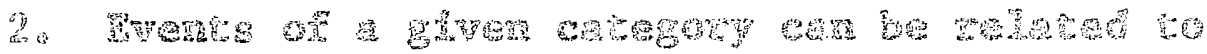

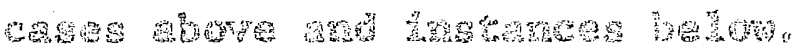

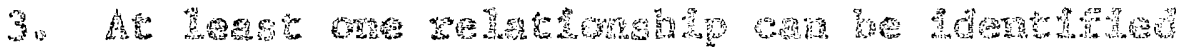

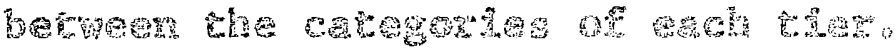

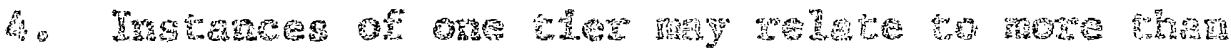

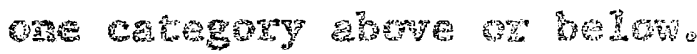

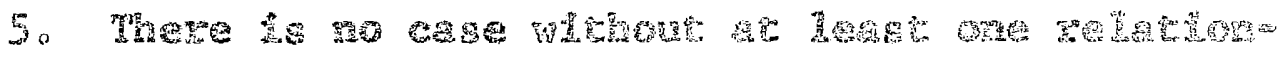

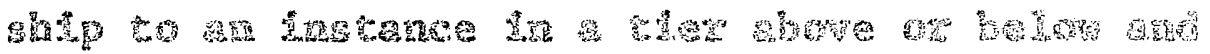

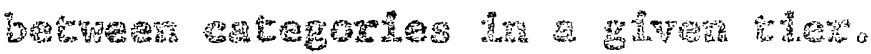

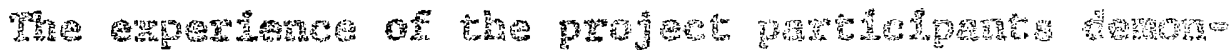

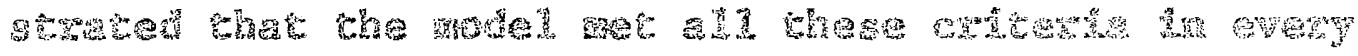
6ats

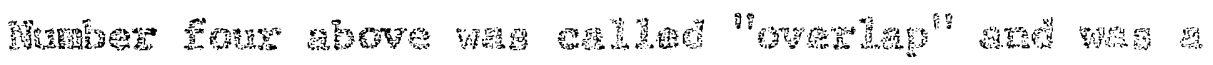

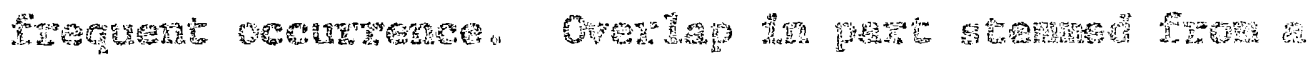

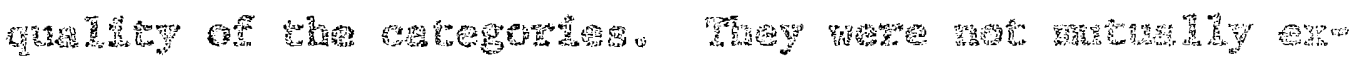

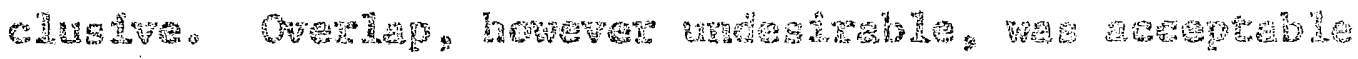

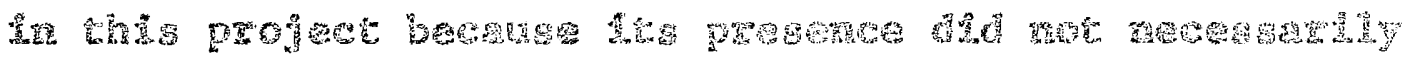

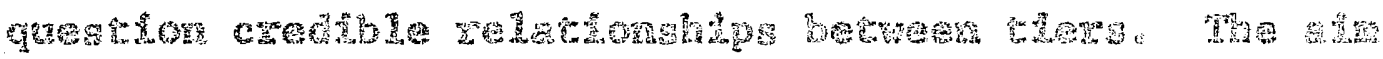

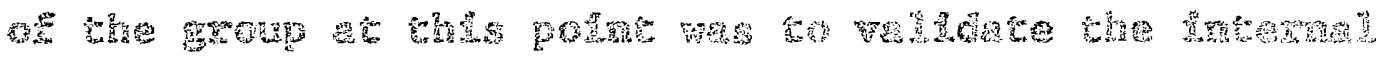

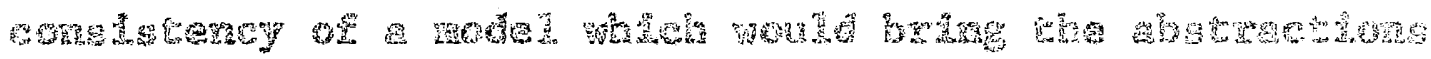

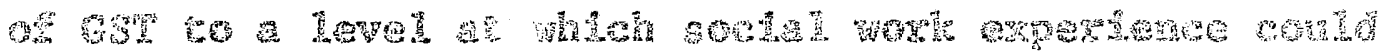

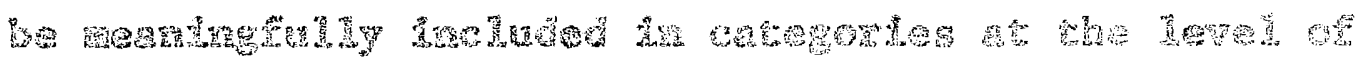
prescas

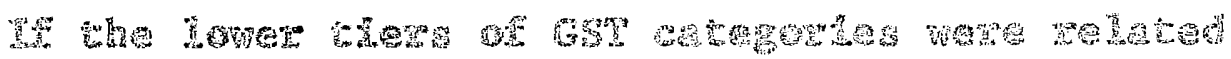

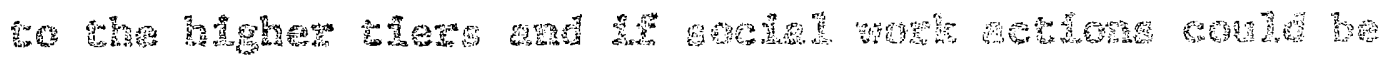




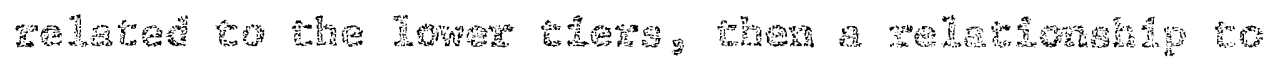

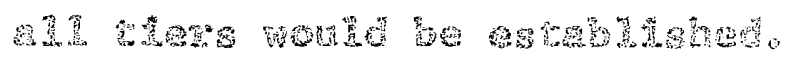

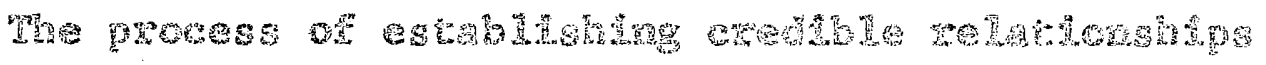

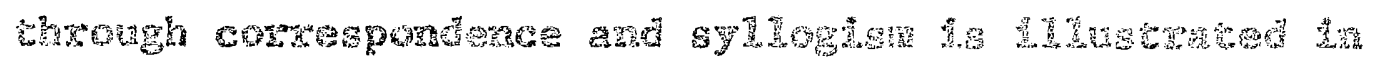

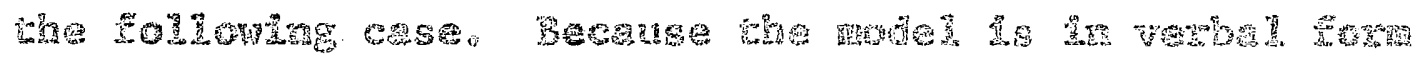

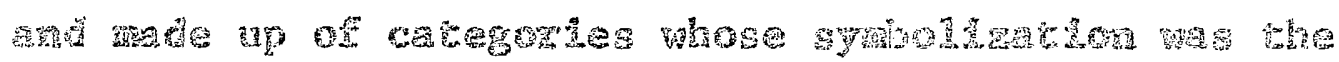

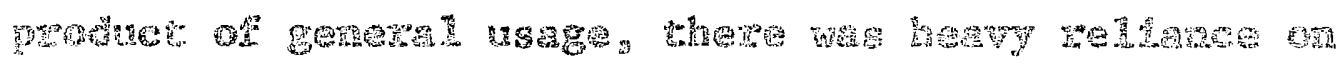

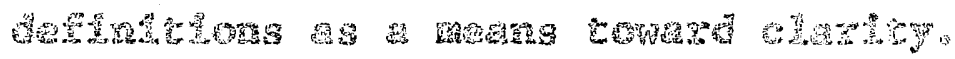

PIn two a

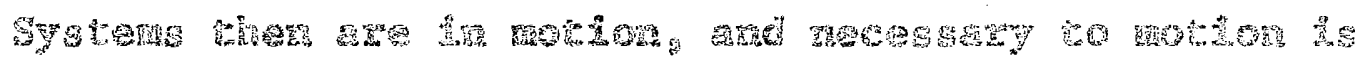
thespase.

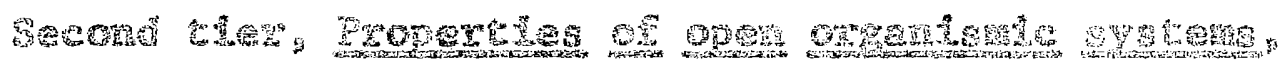

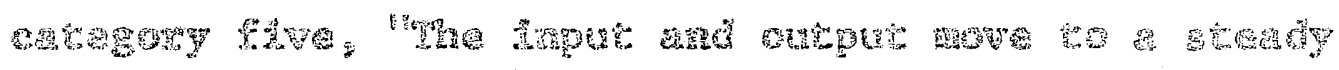

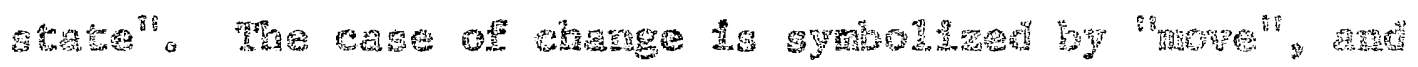

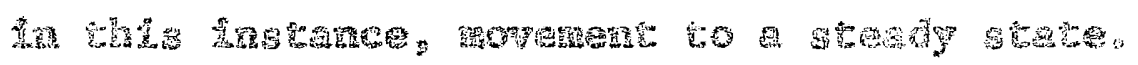

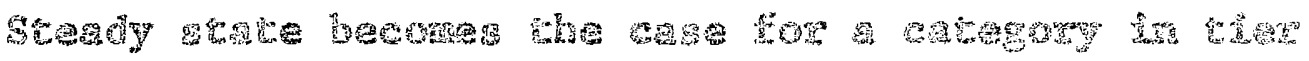

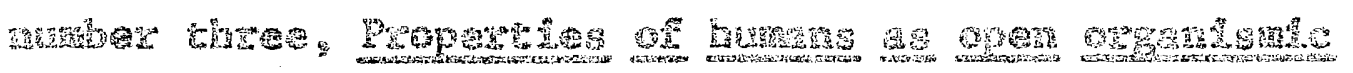

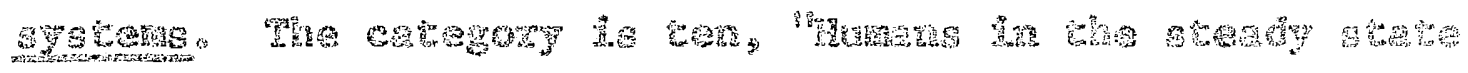

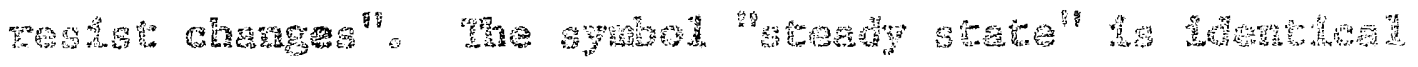

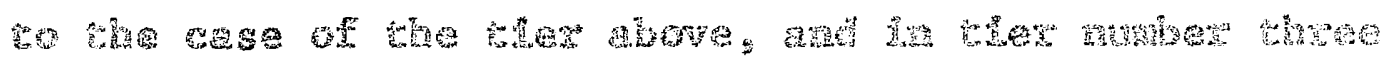
5.

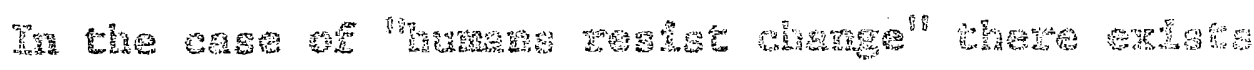

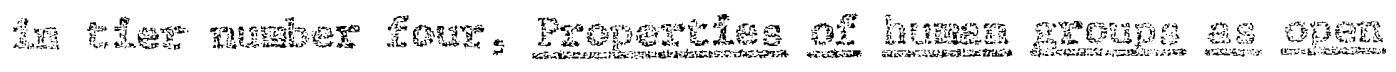

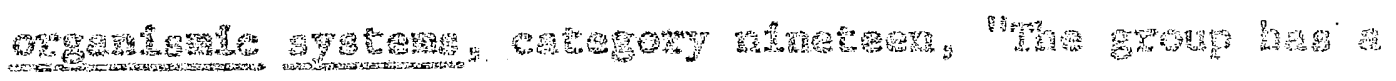

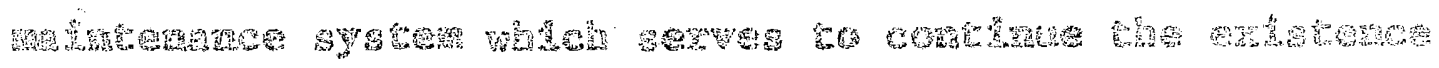




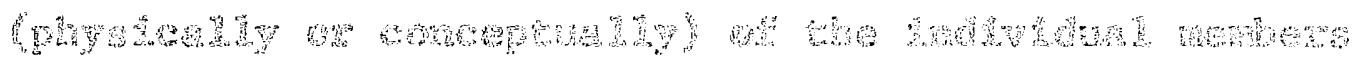

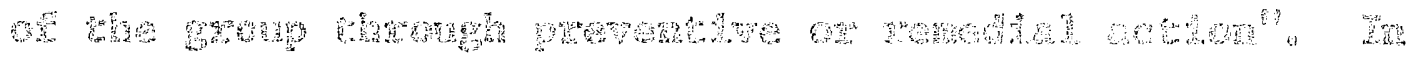

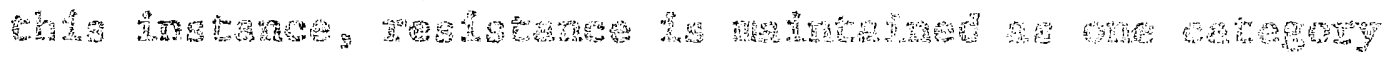

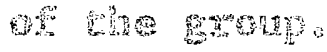

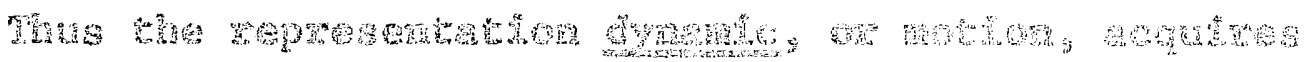

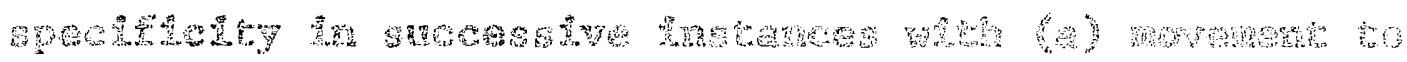

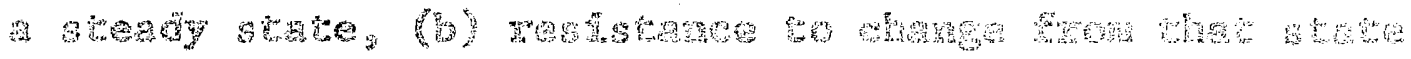

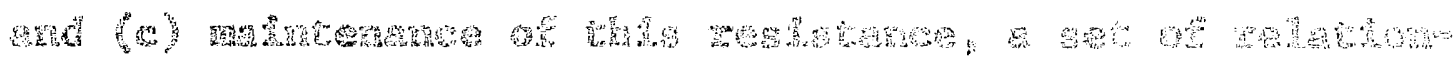

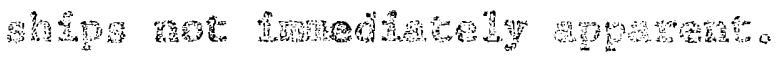

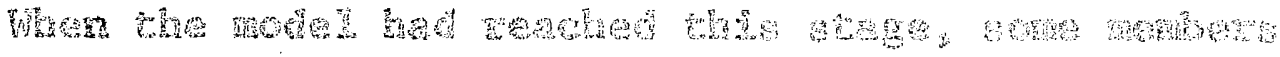

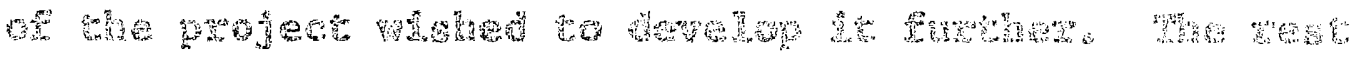

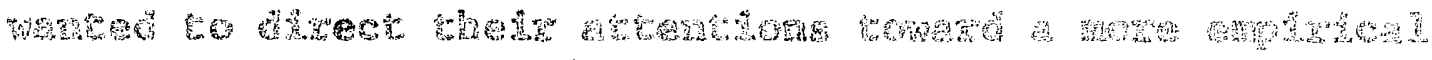

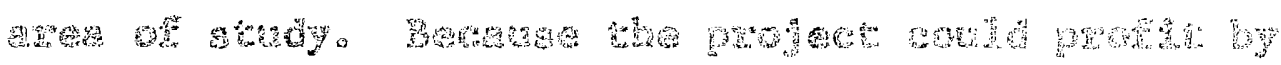
An

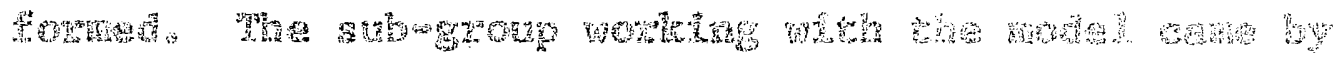

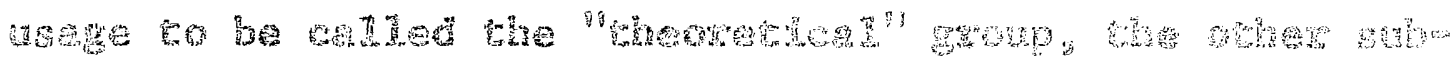

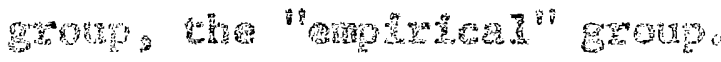

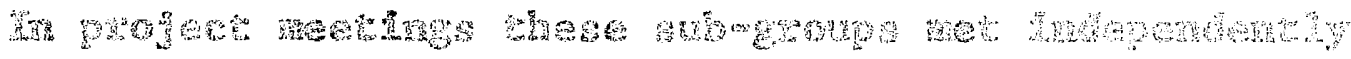

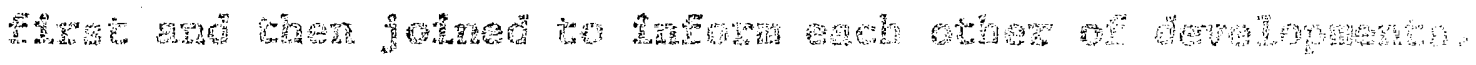

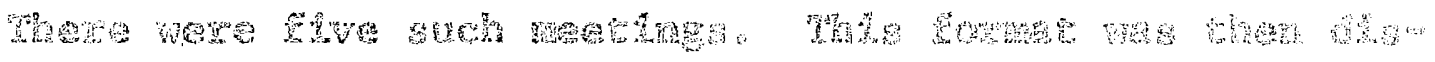

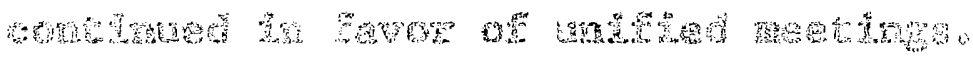

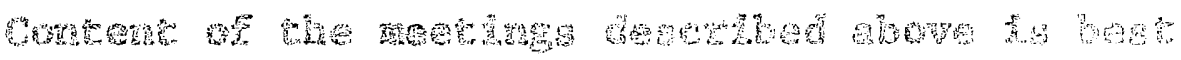

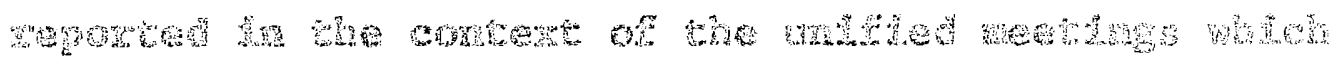

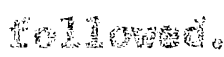

Thin fon

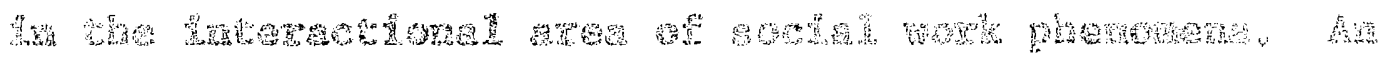




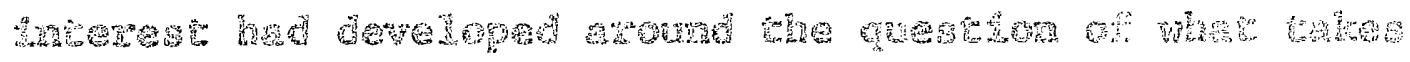

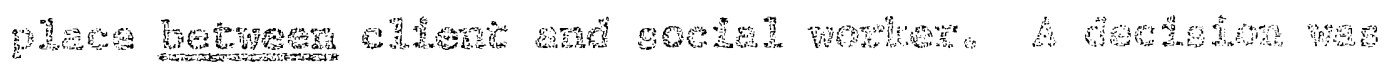

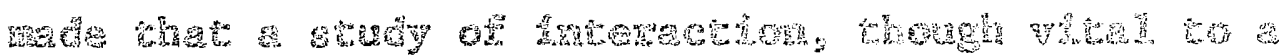

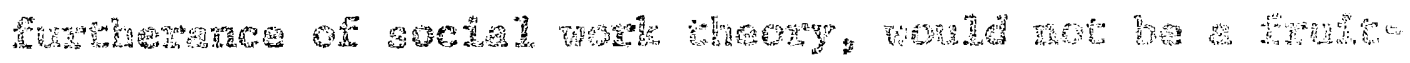

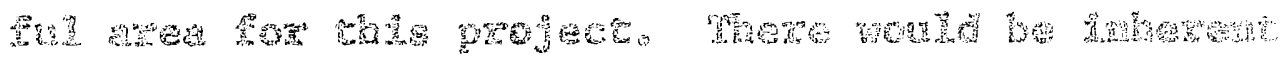
6. Abra

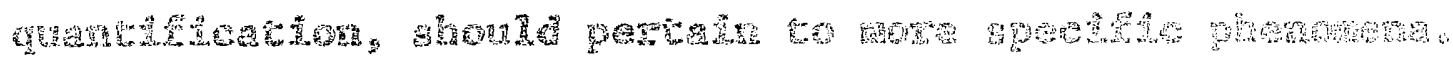

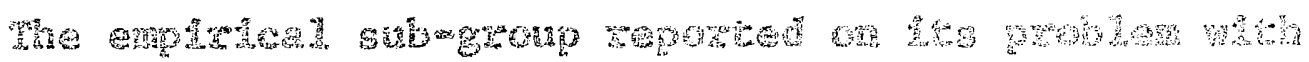

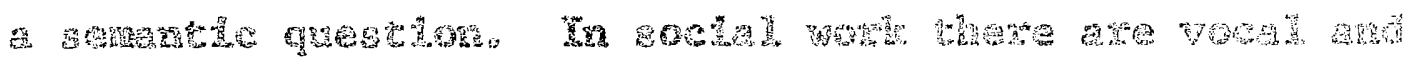
Fiss

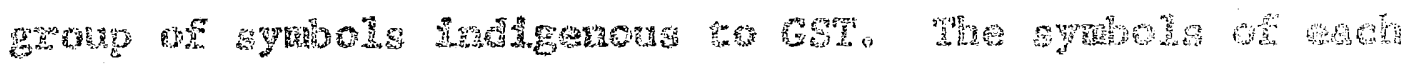

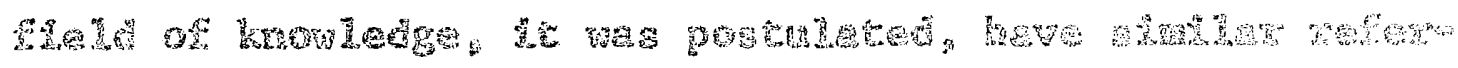

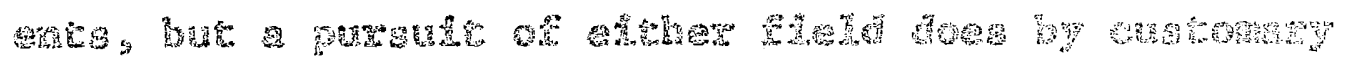
Bs.

Tha

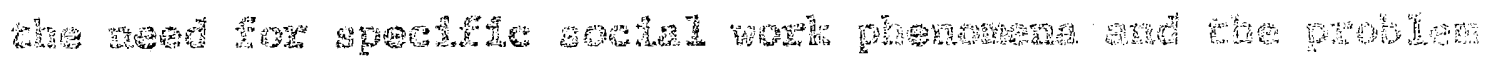

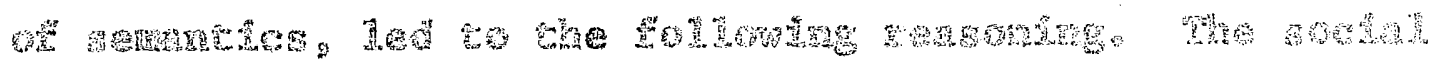

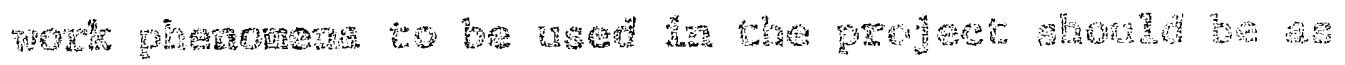

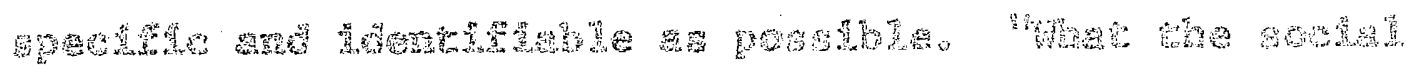

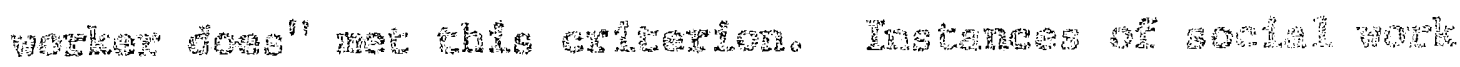

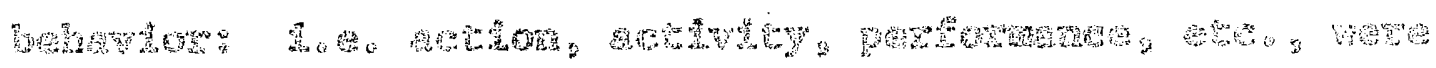
A

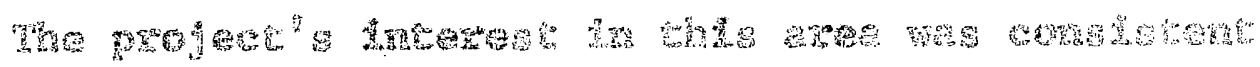
m. Wh 


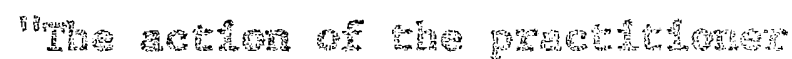

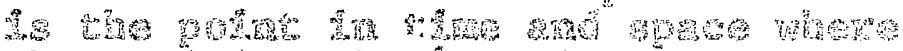

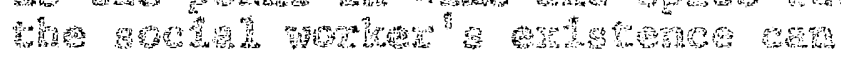

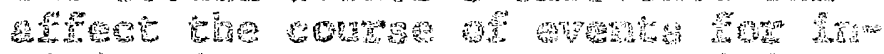

dy

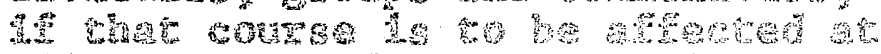

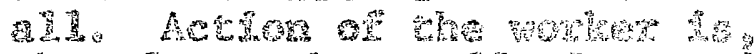

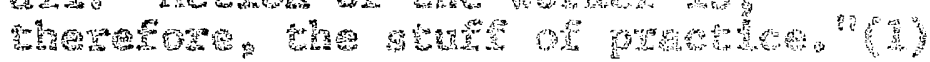

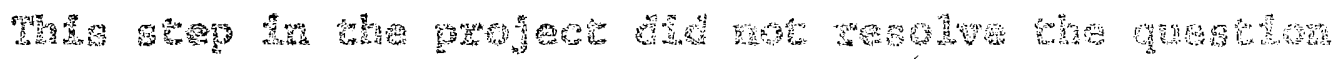

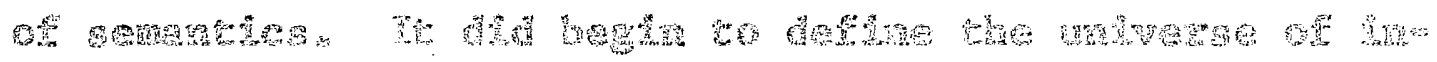

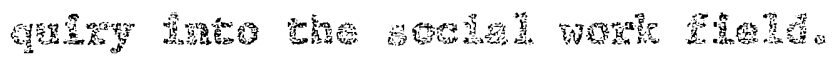

A

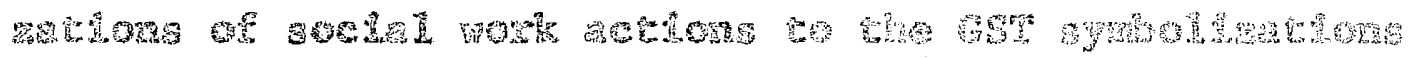

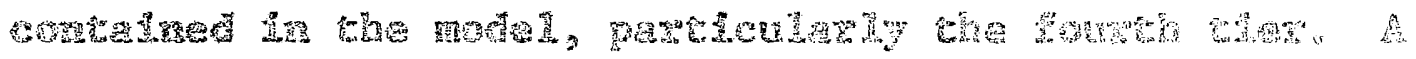

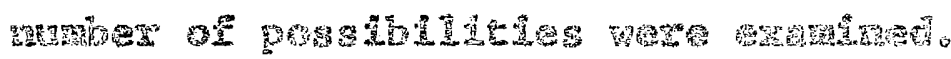

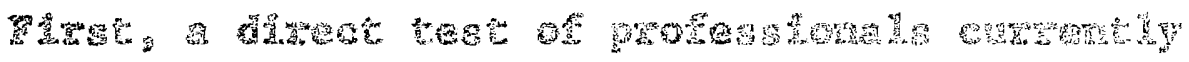
any

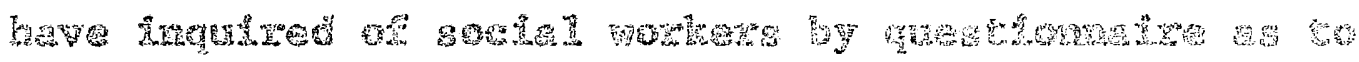

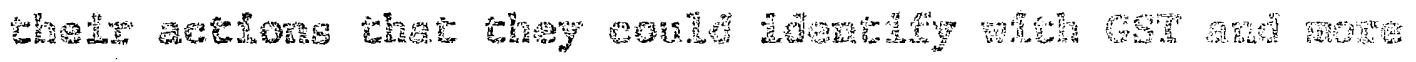

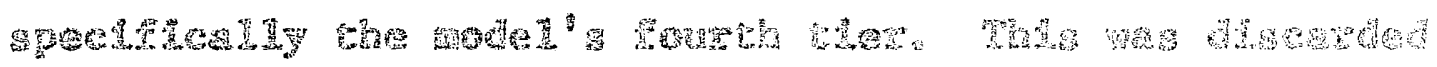

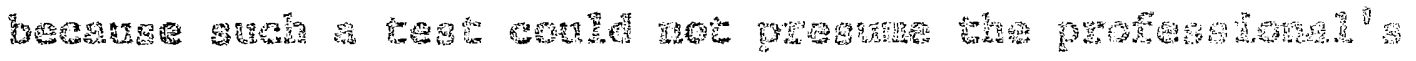
Mrow

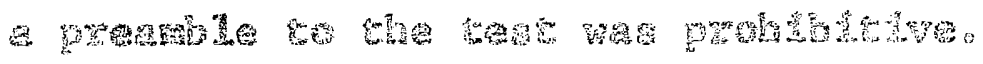

The socrod pons

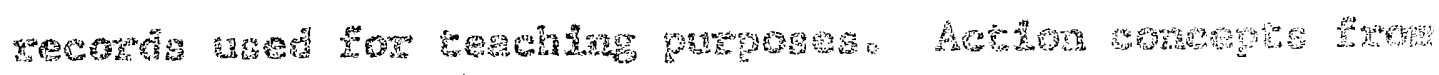

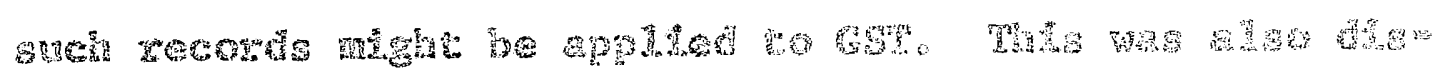

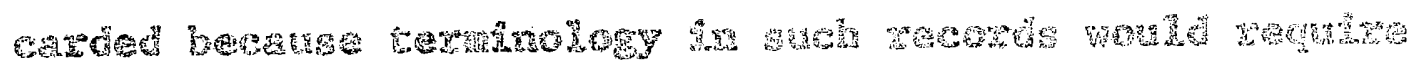

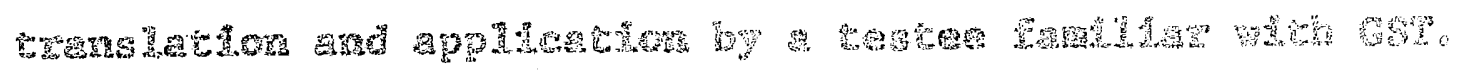
Thas

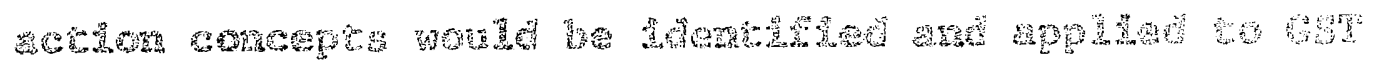




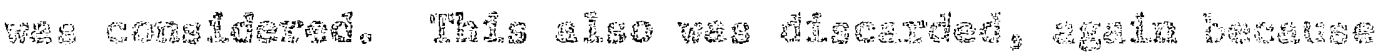

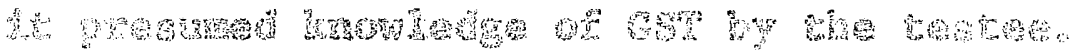

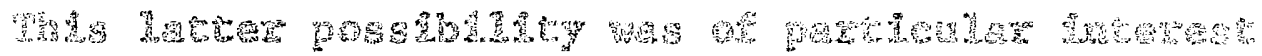

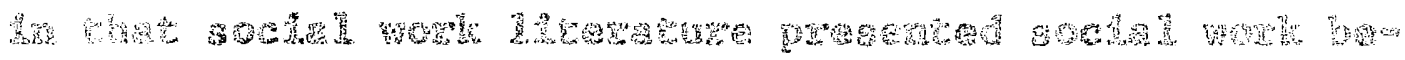

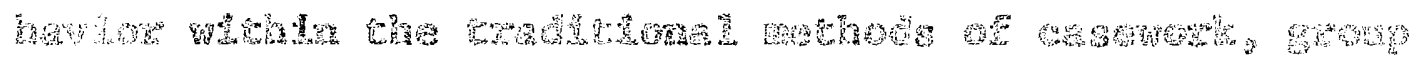
now

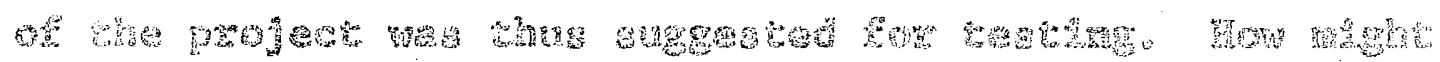
act

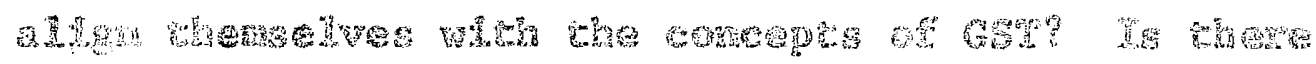

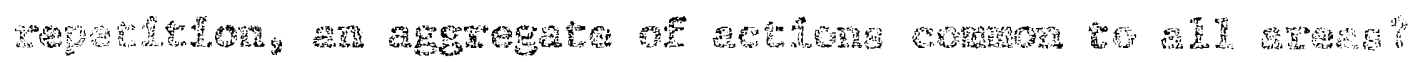

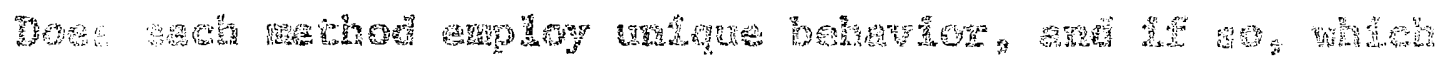

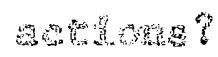

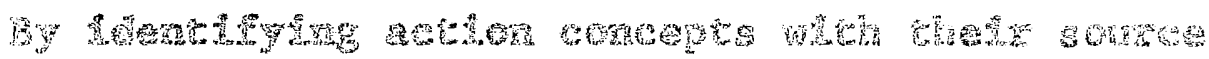

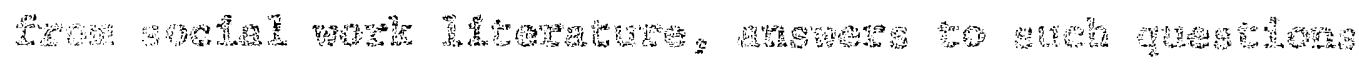

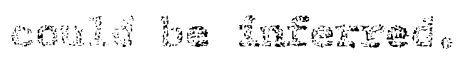

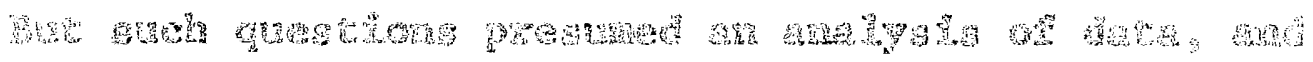

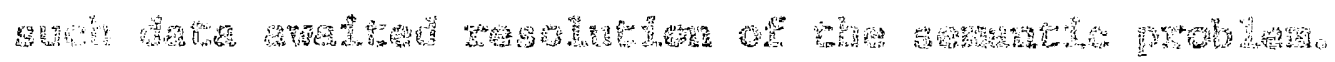

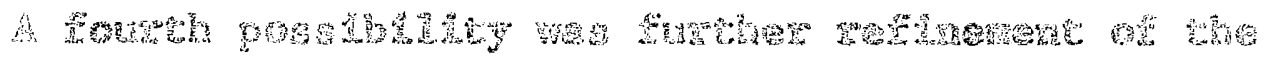

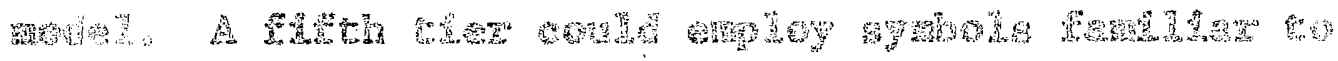

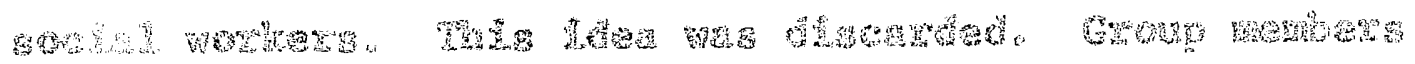

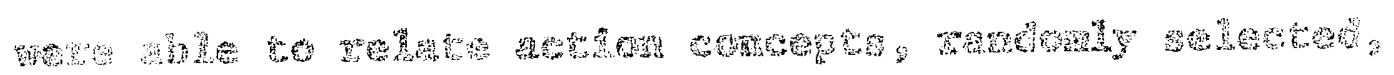

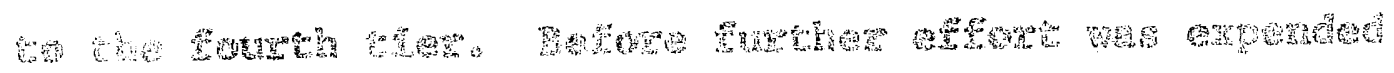

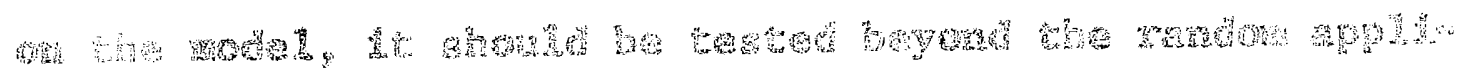

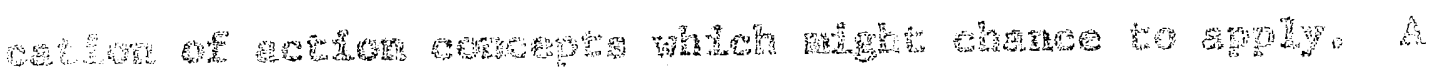

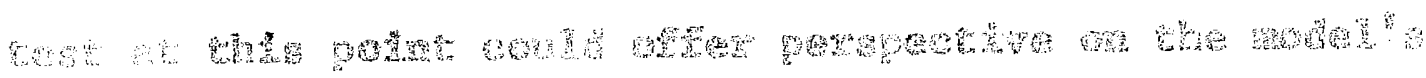

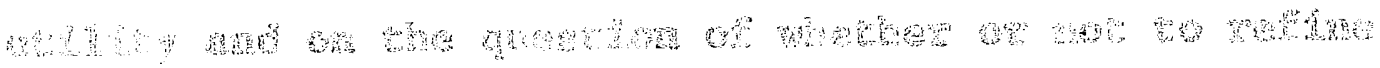
when was 


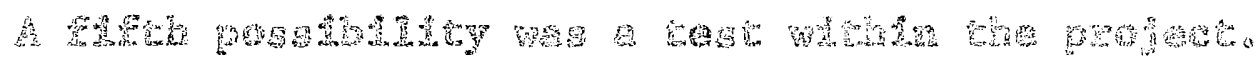

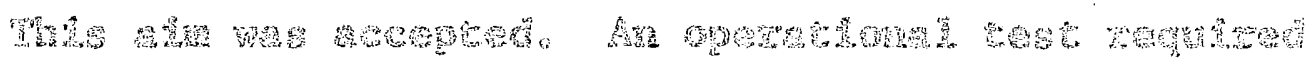

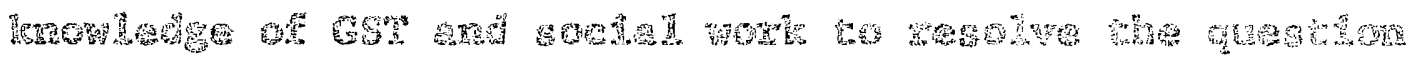

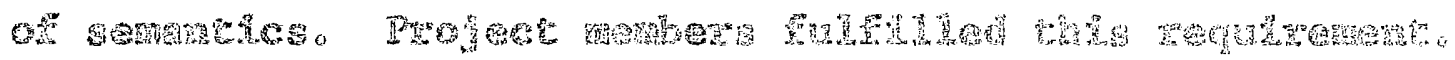

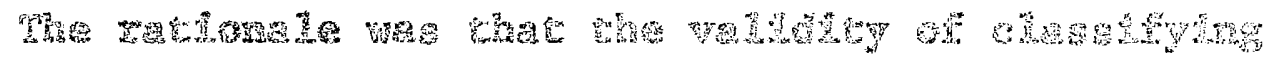

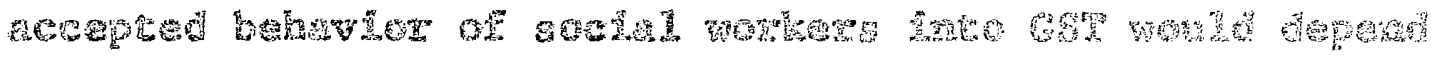

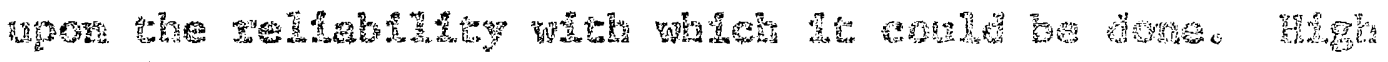
corraspwathere between trow

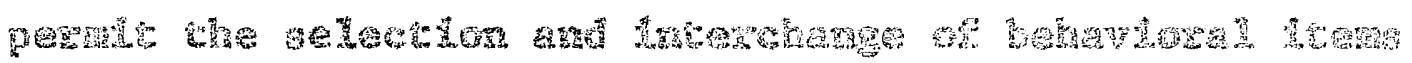

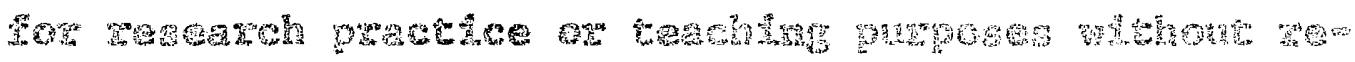

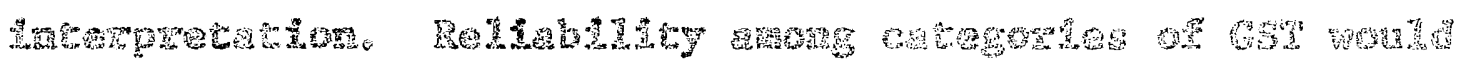

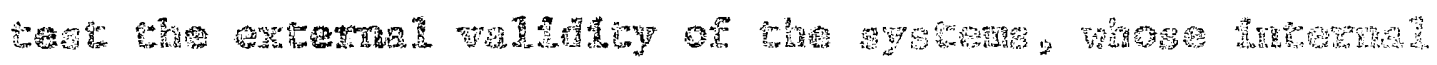

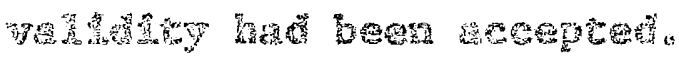

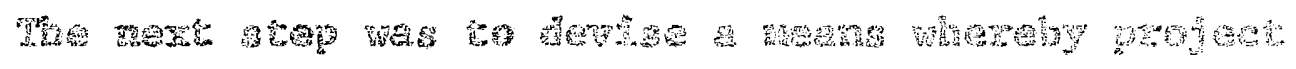

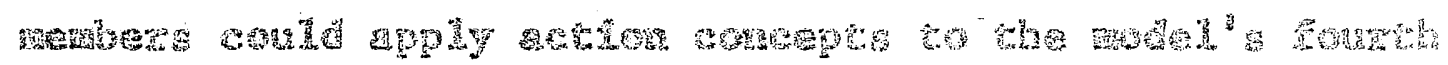

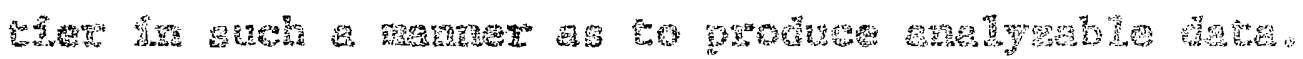

Thy ors soed

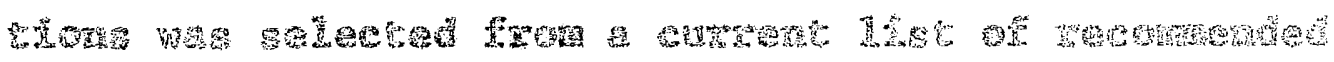

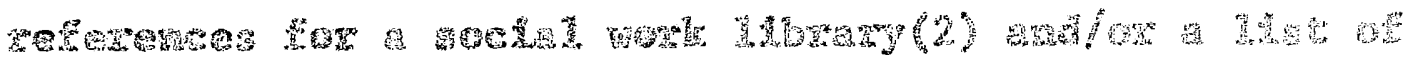

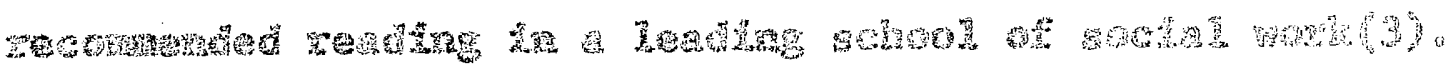

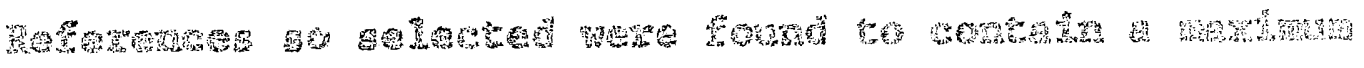

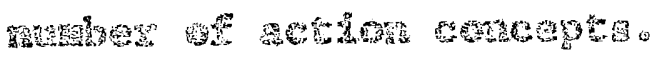

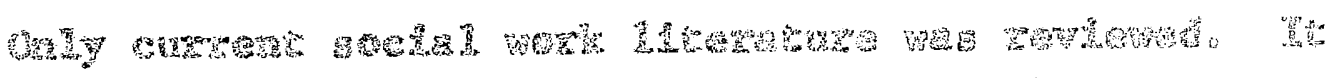

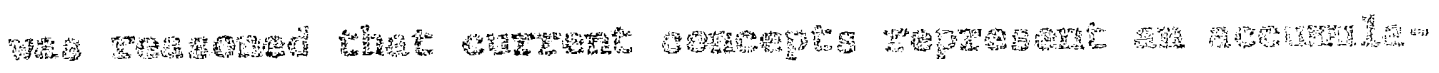

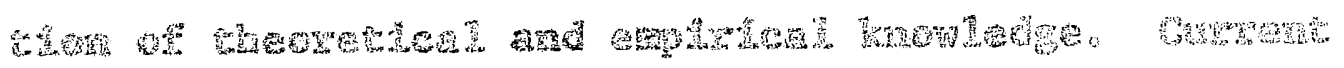




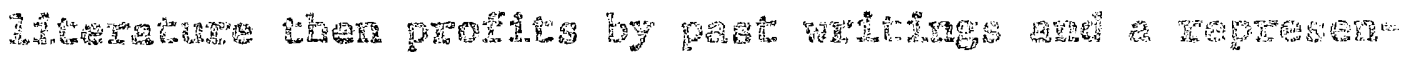

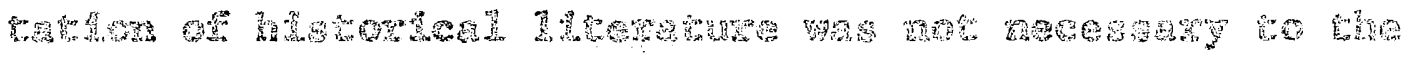

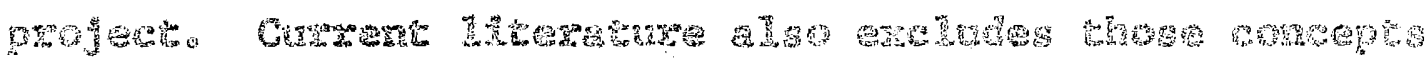

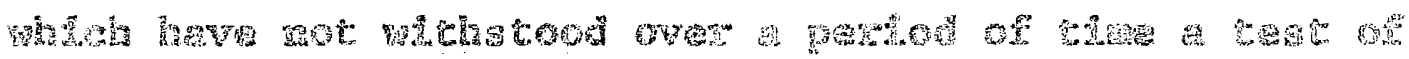

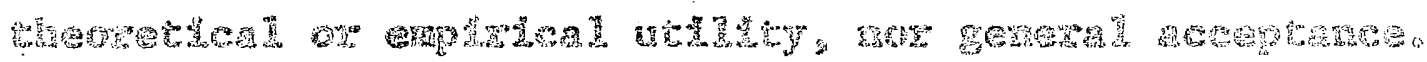

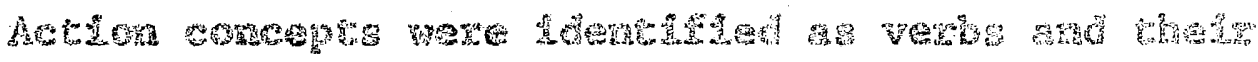
路or

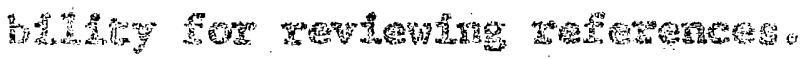

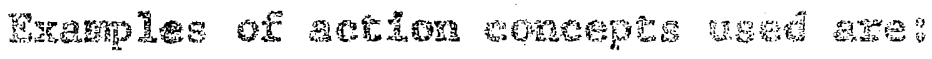

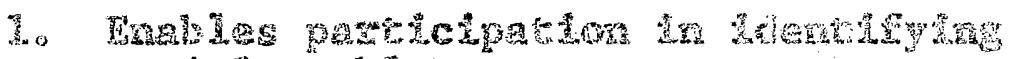
soctal wablens?

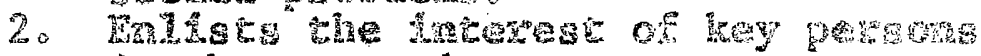

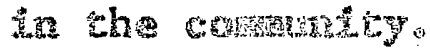

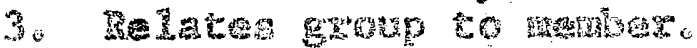

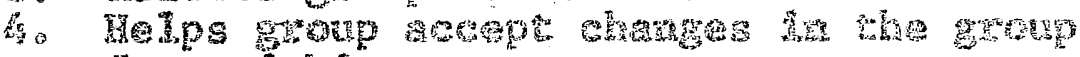

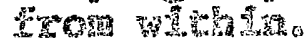

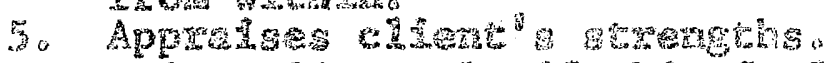

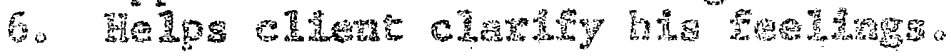

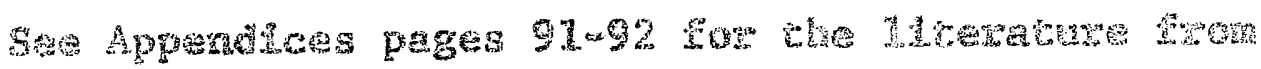

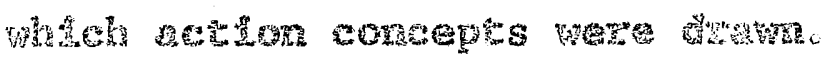

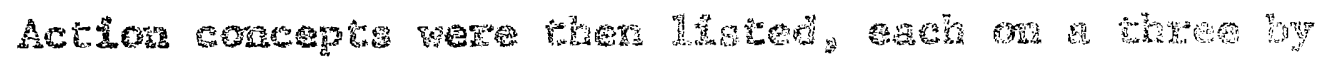

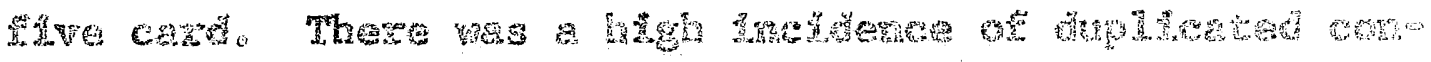

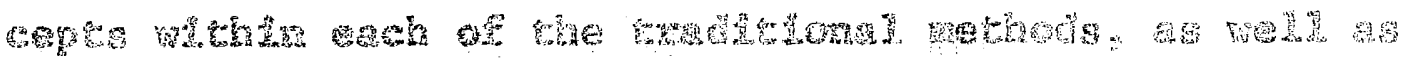

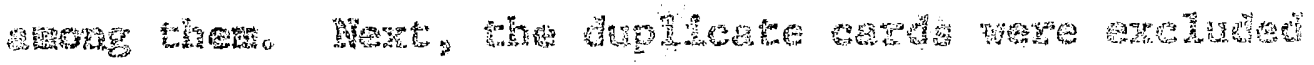
W.

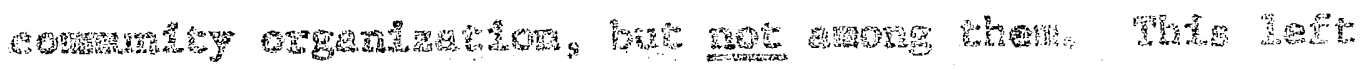

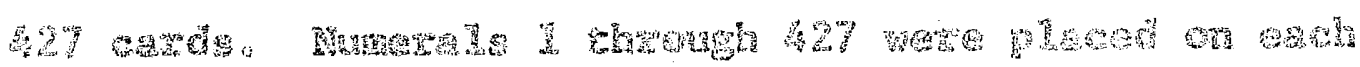

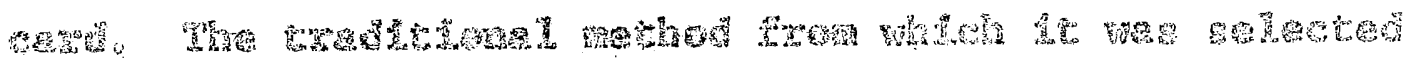

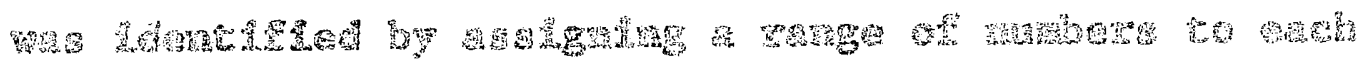

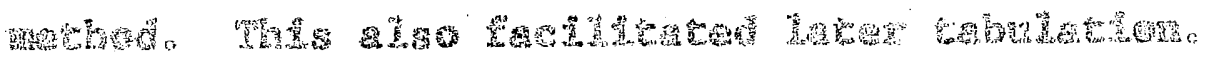


The

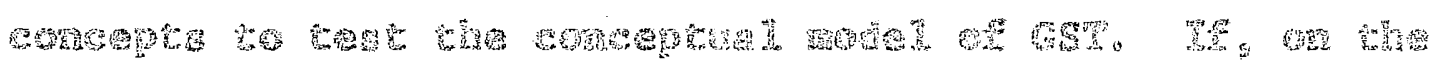

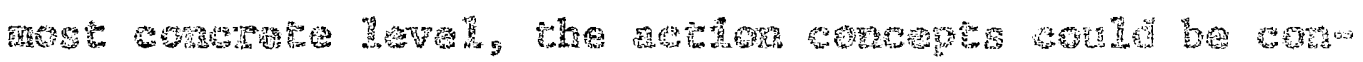

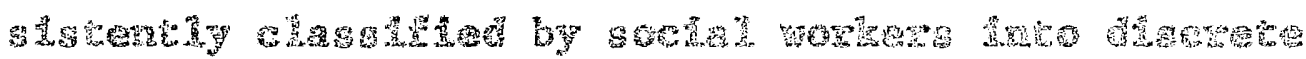

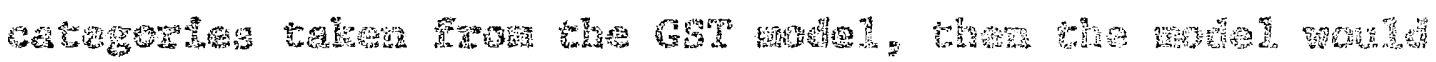

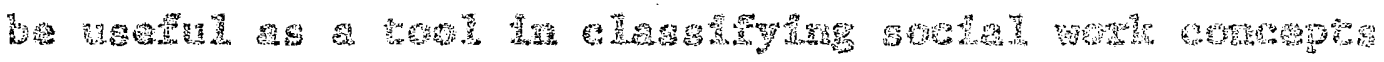

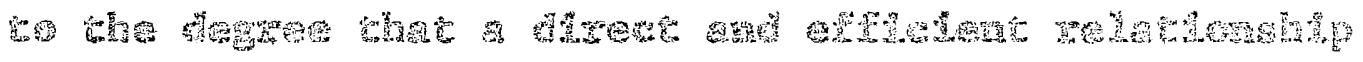

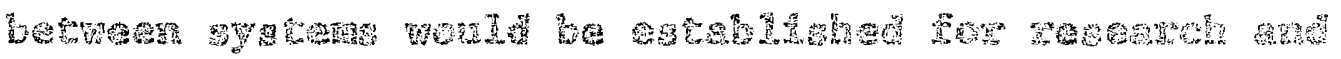

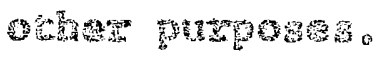

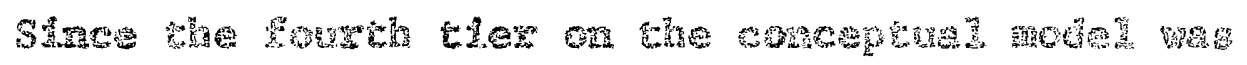

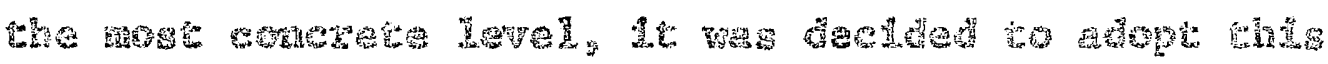

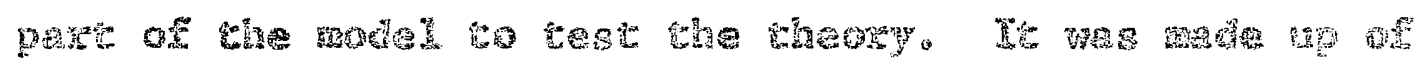

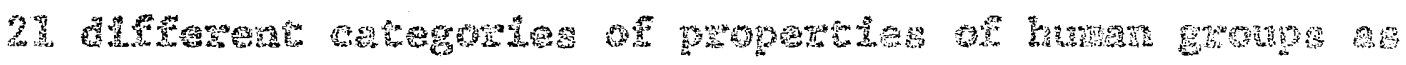

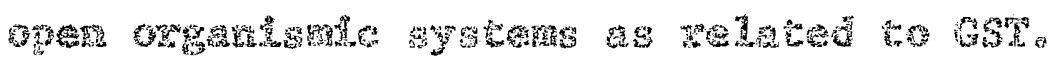

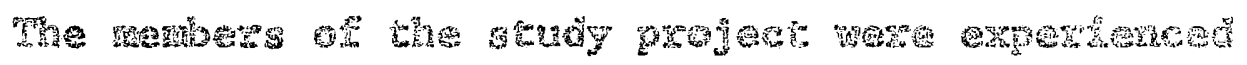

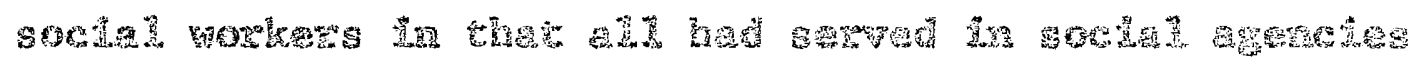

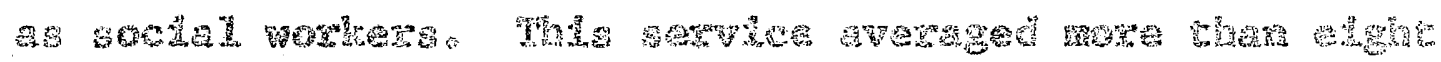

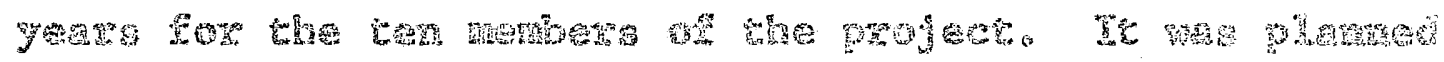

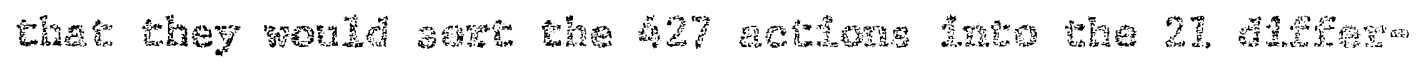

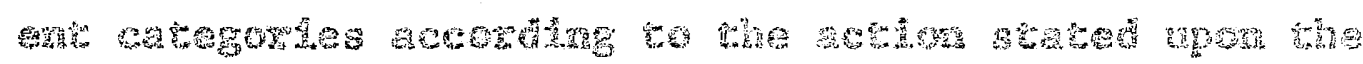

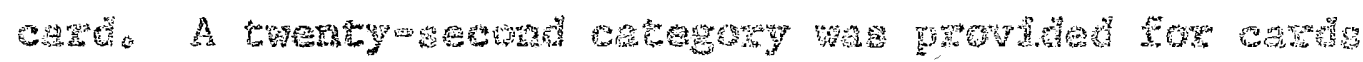

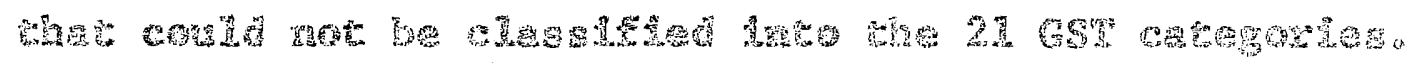

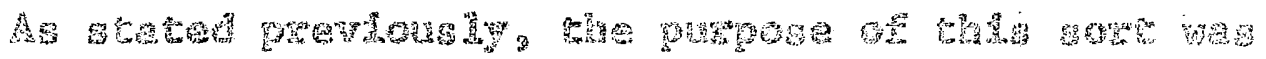

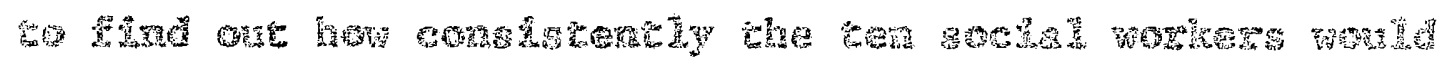

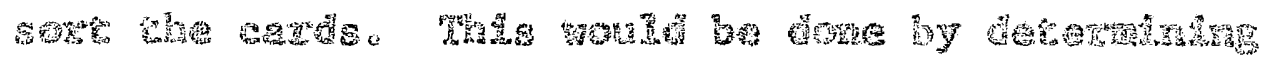

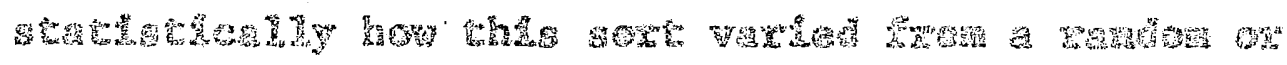


Wy gortols

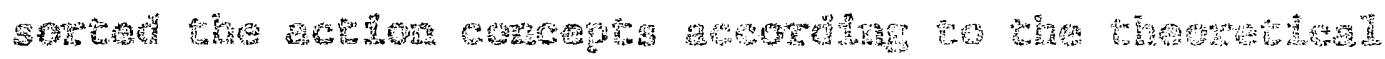

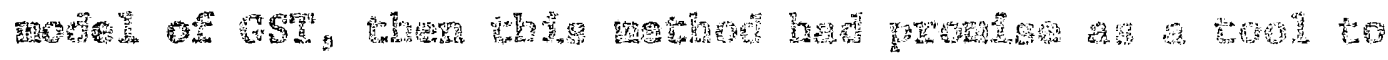

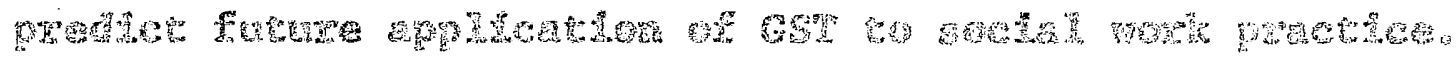

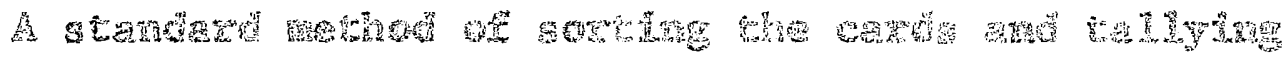

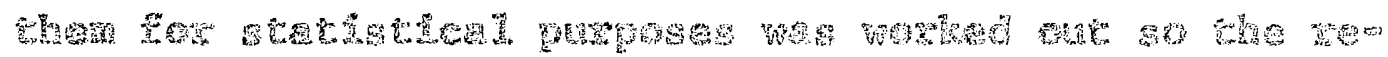

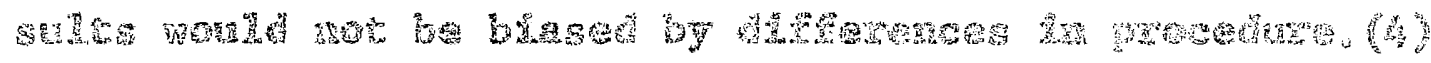

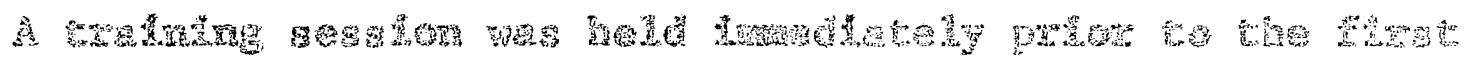

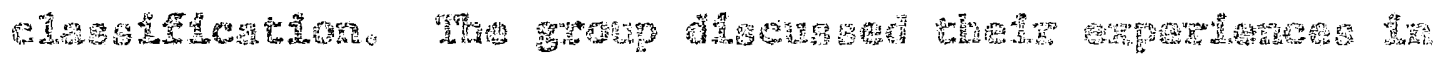

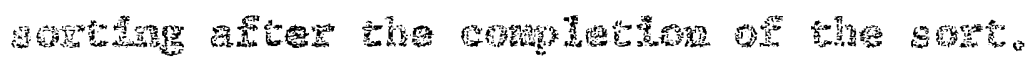

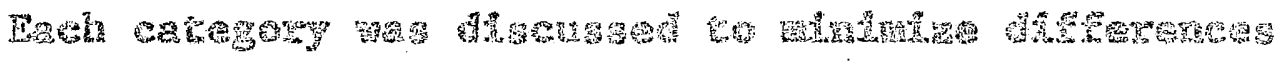

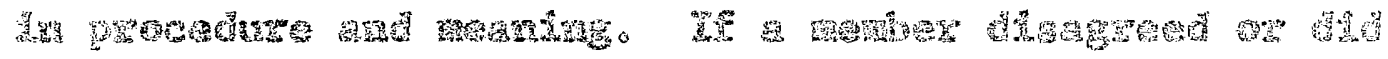

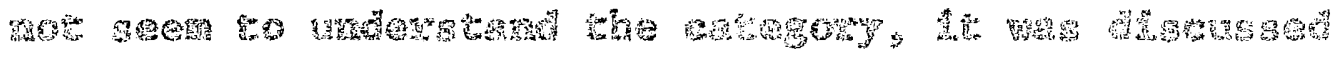
81

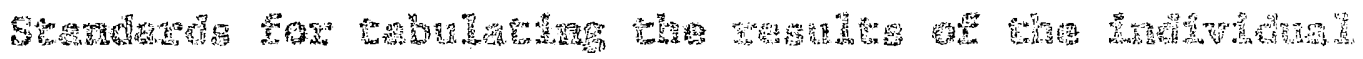

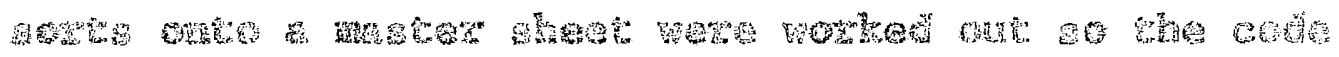

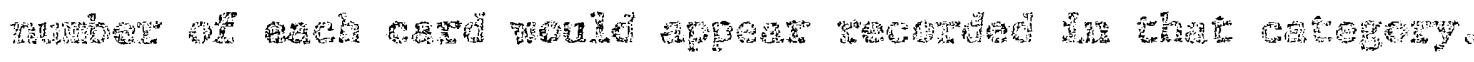

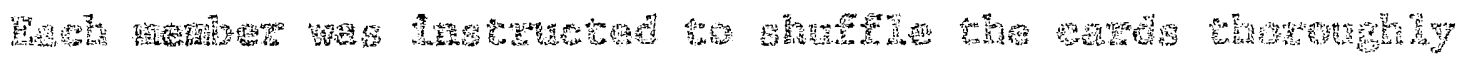

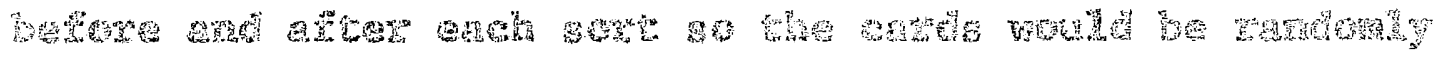

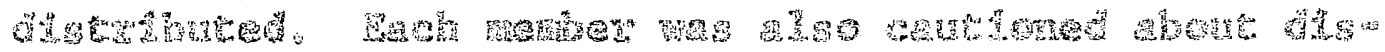

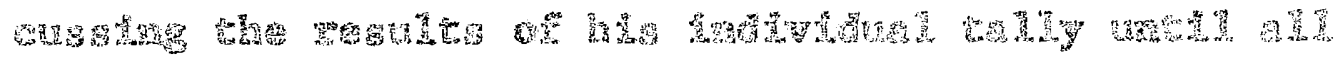

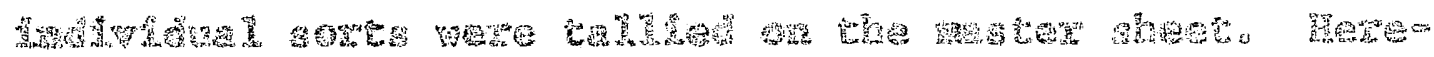

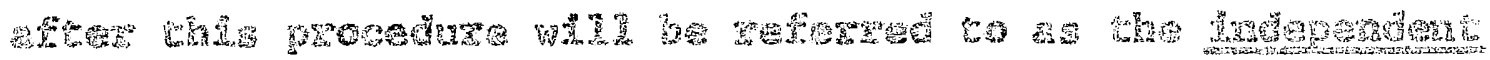
$\sin 2$ 


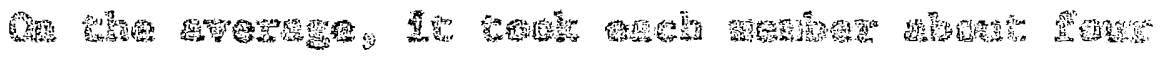

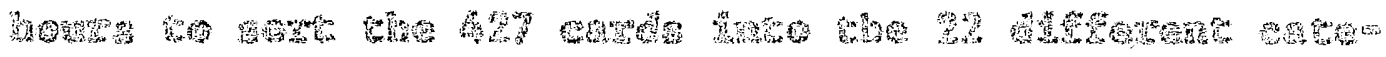

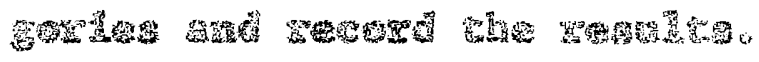

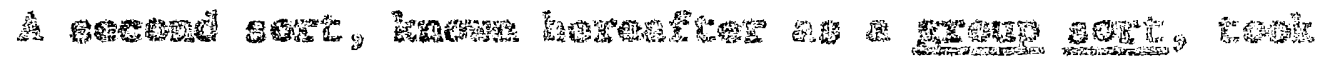

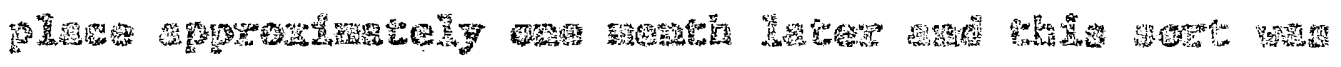

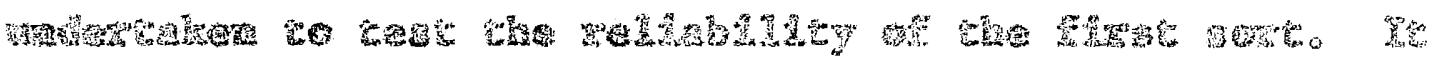

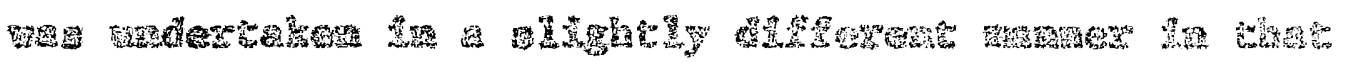

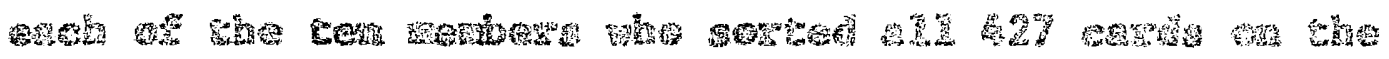

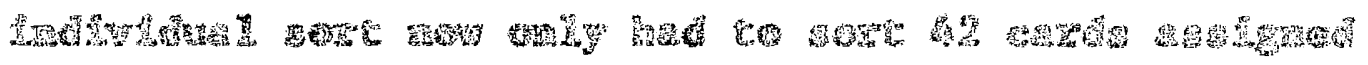
Aft

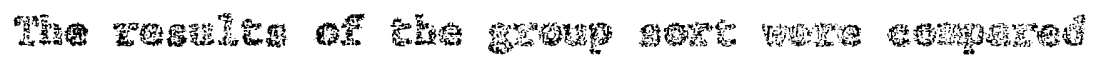

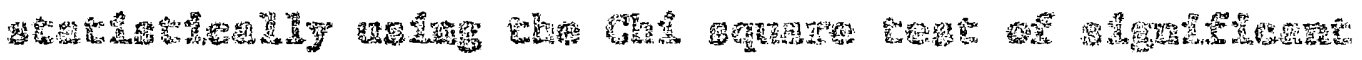

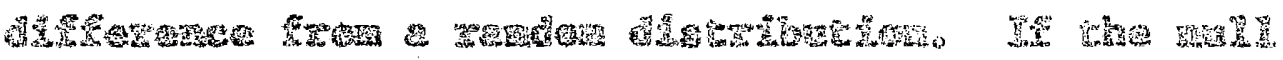

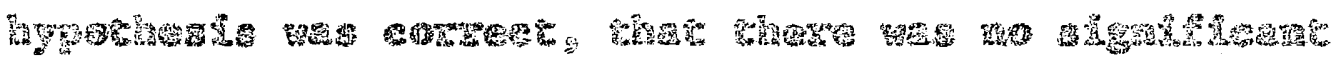

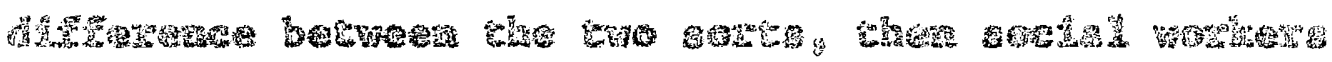

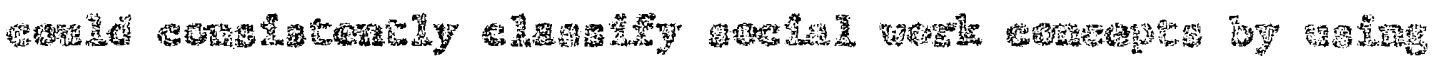

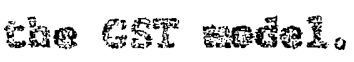

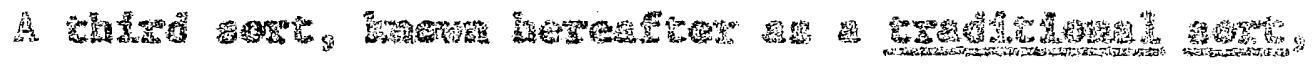
vas

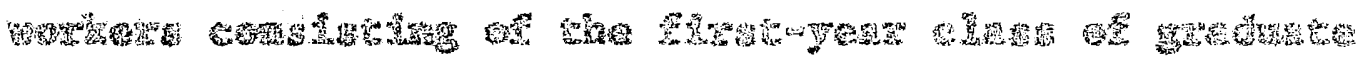

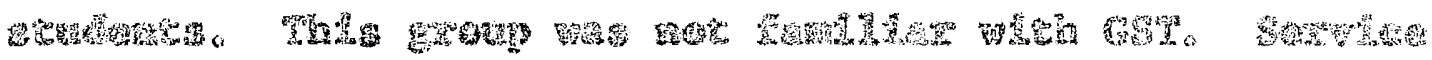

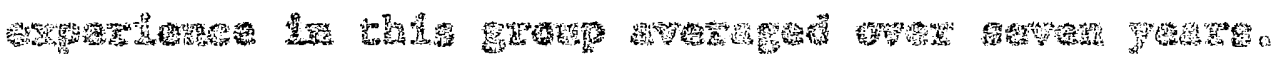

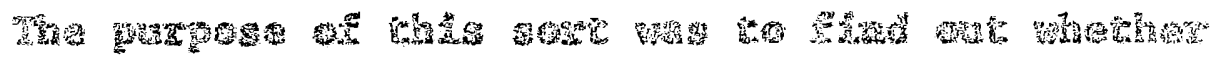

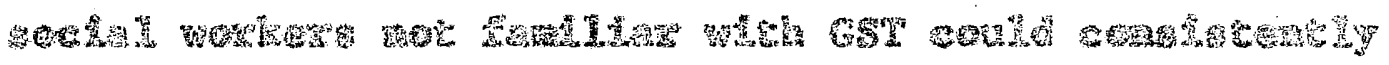

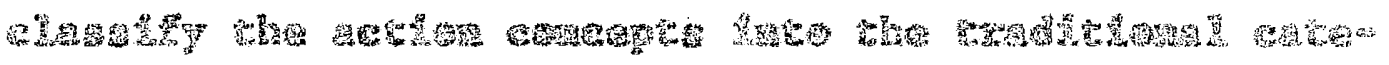

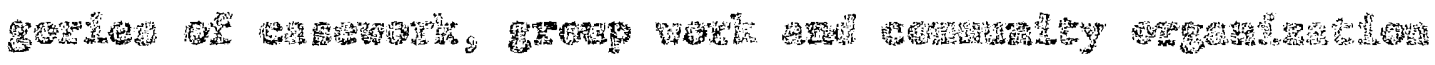




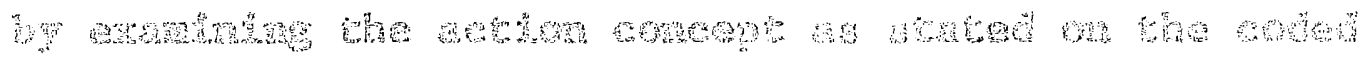

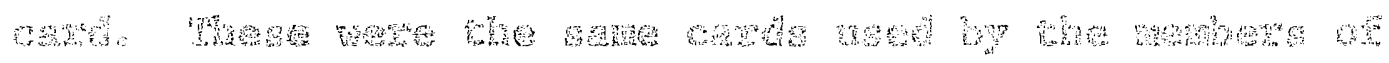

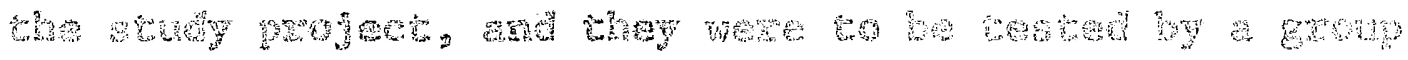

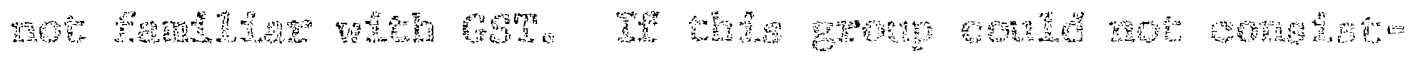

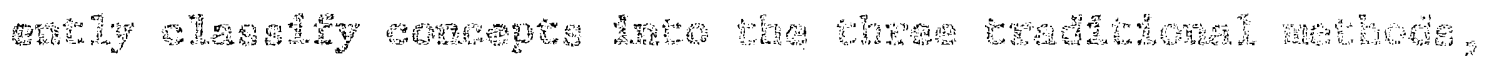

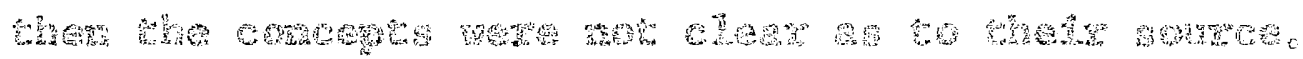

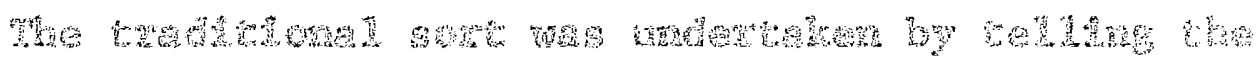

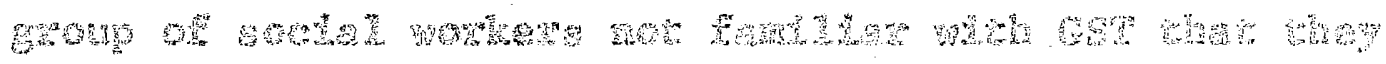

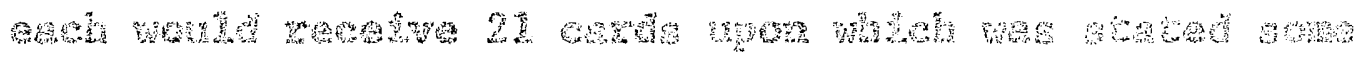

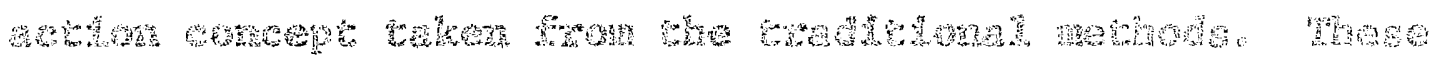

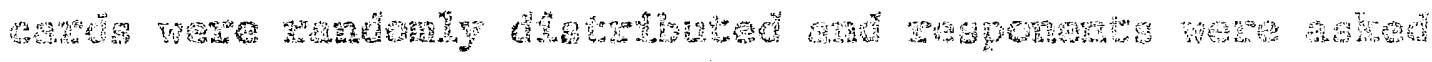

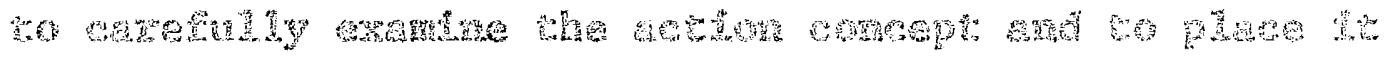

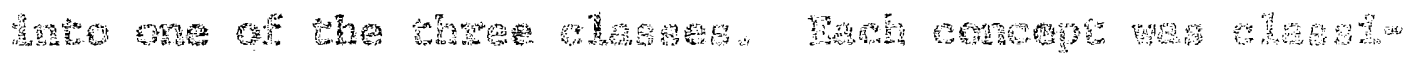

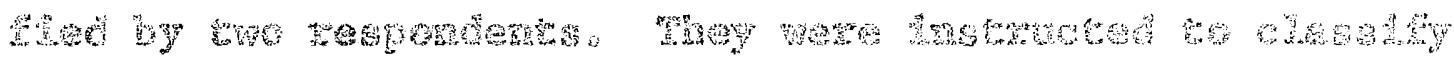

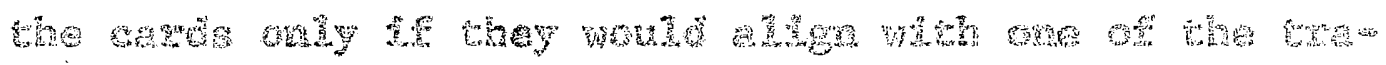

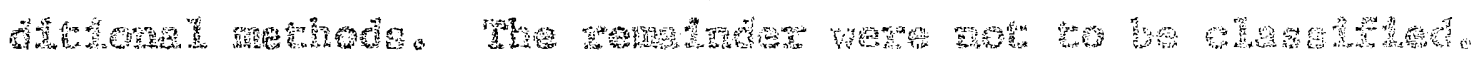

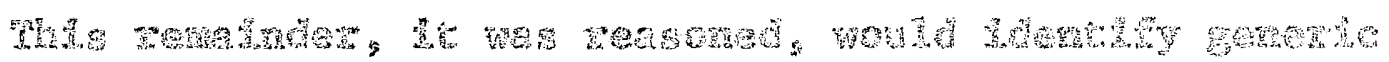

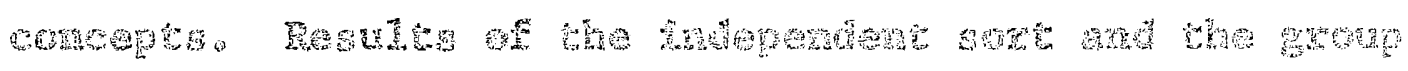

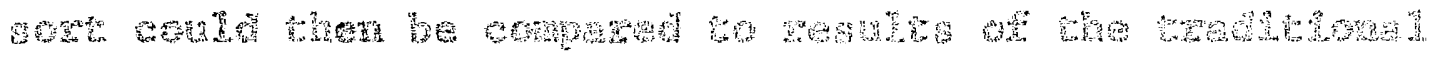

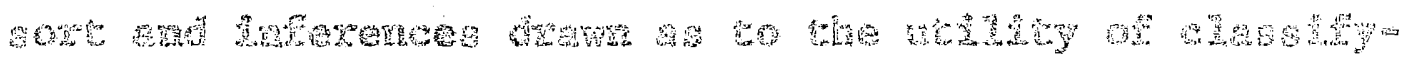

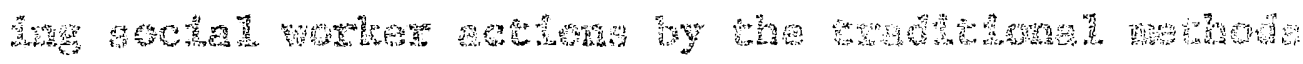

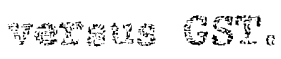

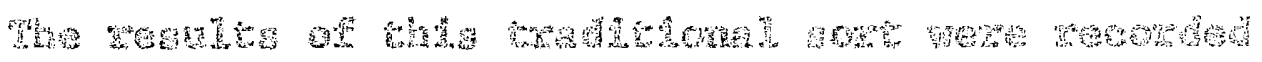

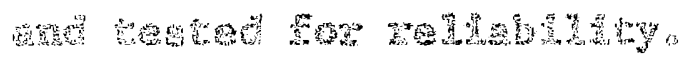

What

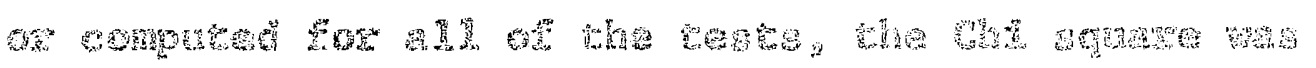




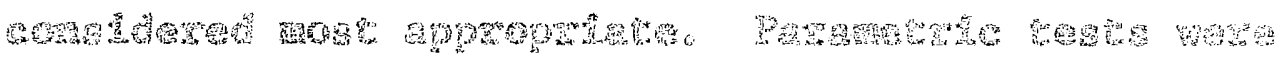

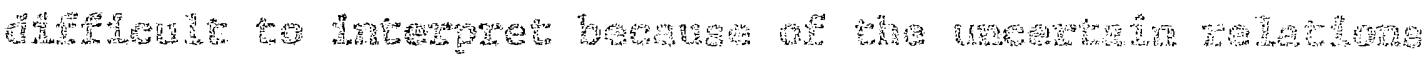

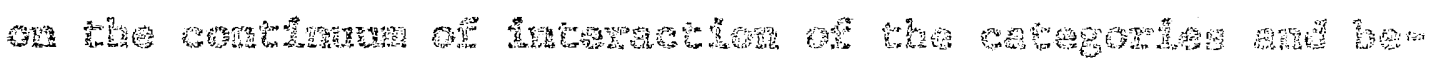

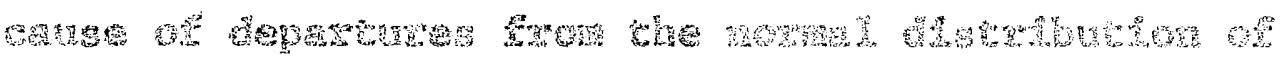

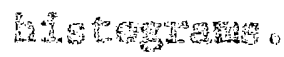

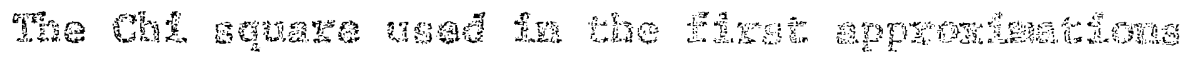

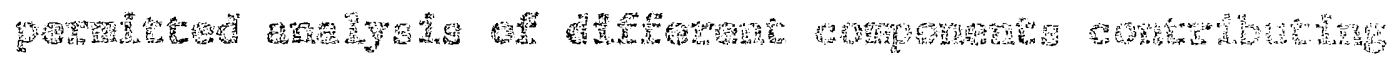

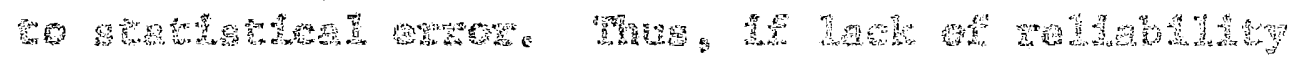

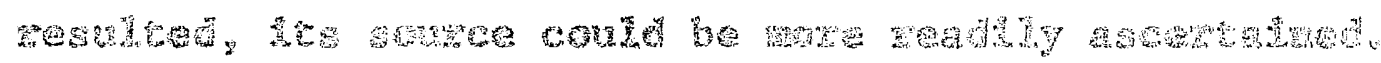

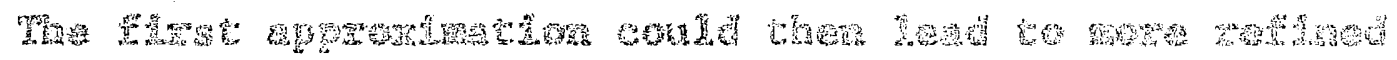

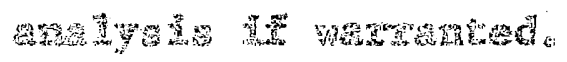

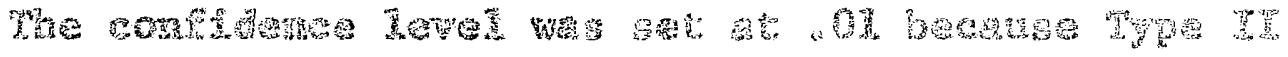
Q 74.

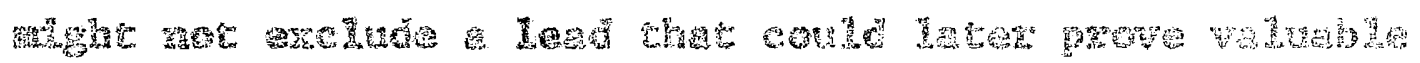

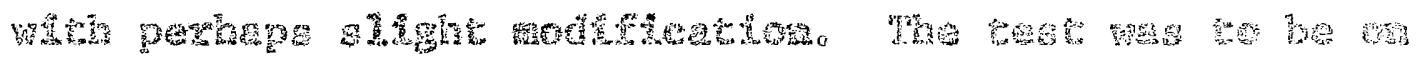

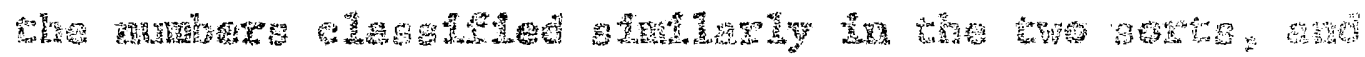

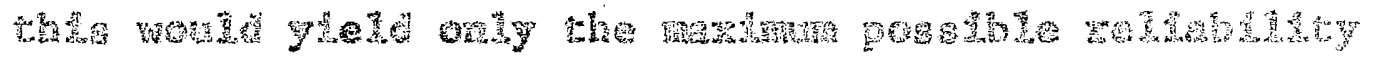

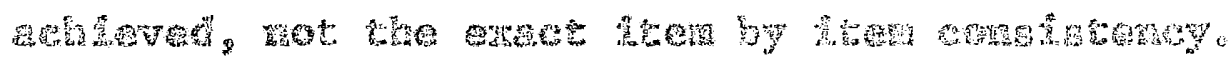

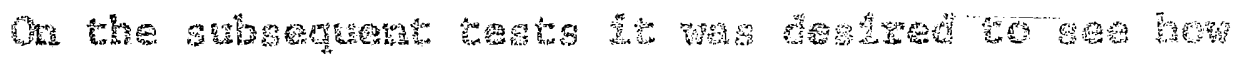

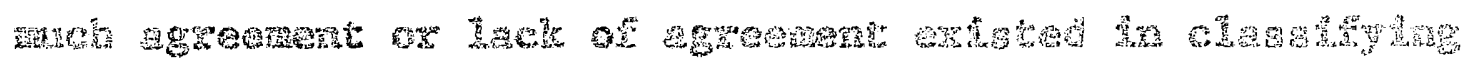

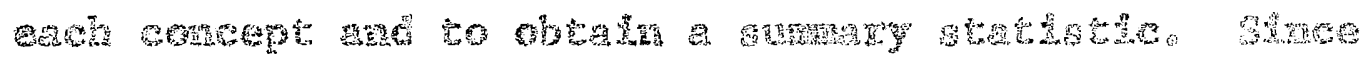
-

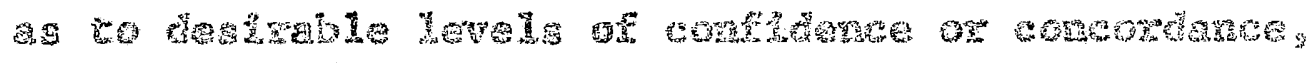

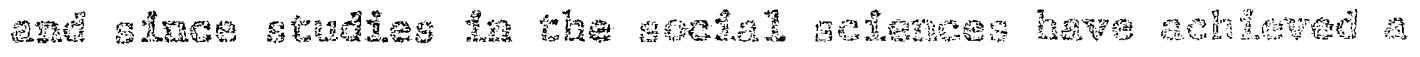
"gind 논 


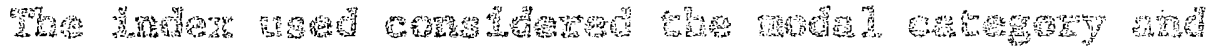
Hery

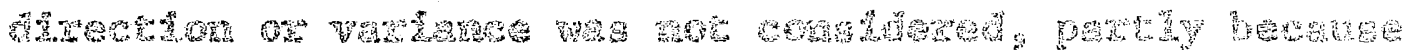

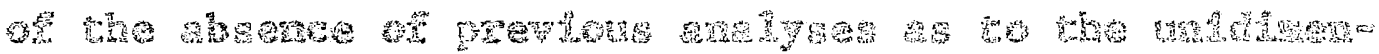

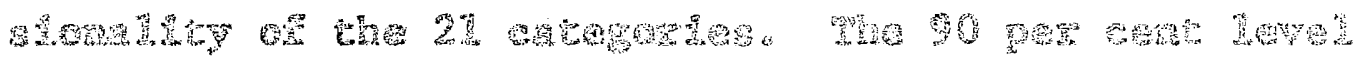

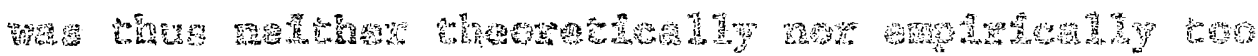
4.

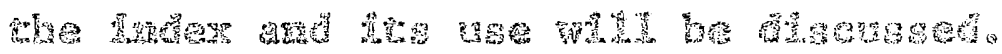

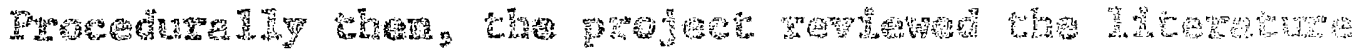

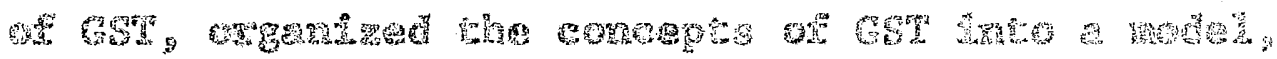
S4

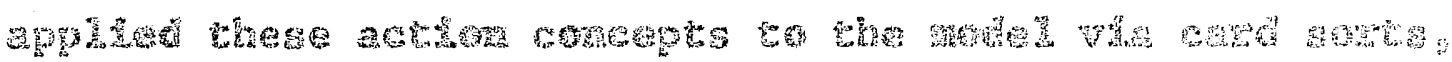

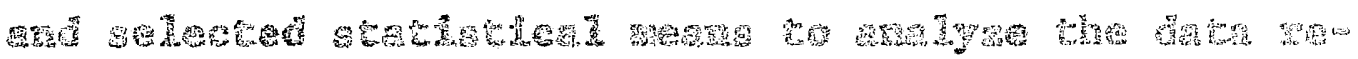
SU1

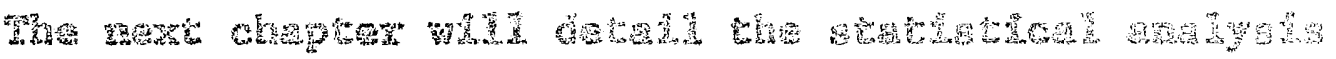

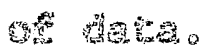


Menplater notes

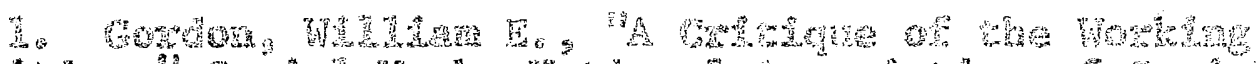

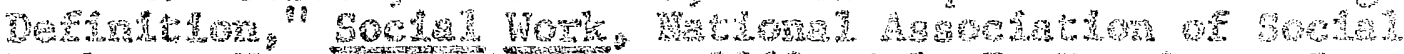

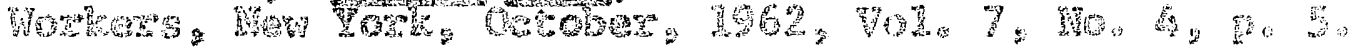

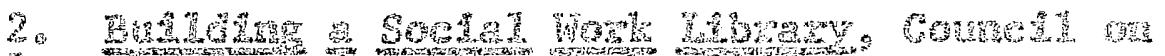

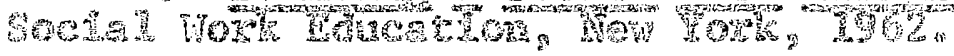

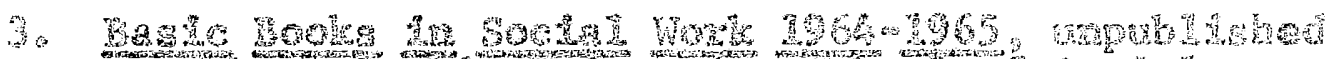

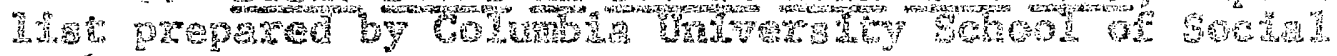
Werge

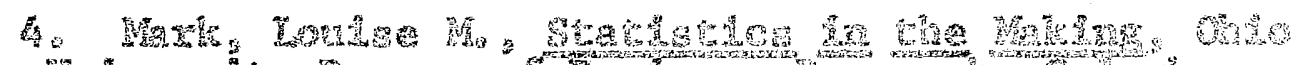

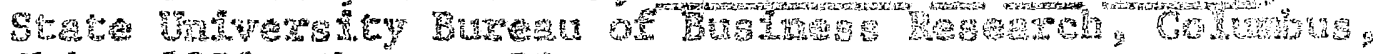

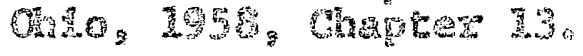




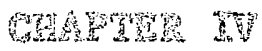

FUN THES

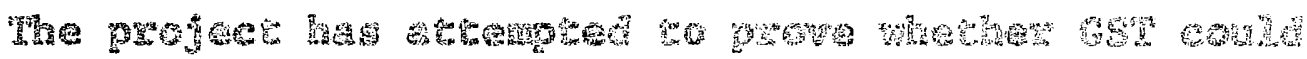

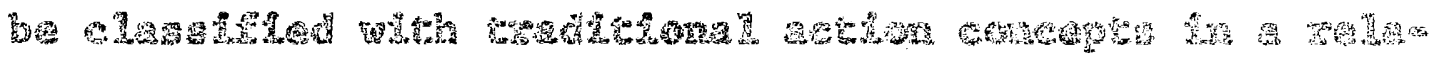

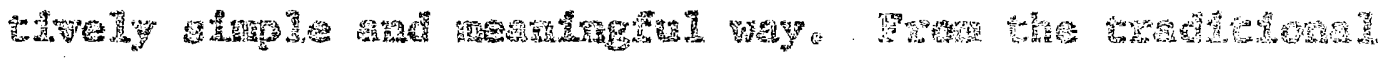

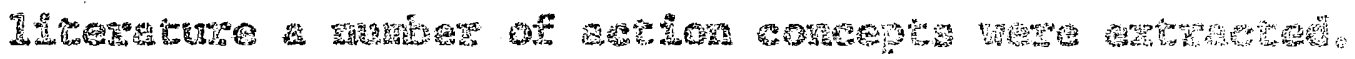

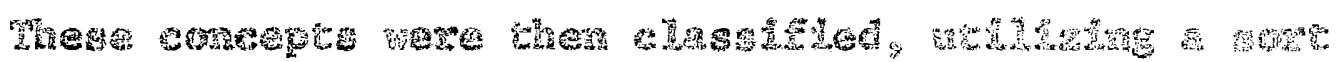

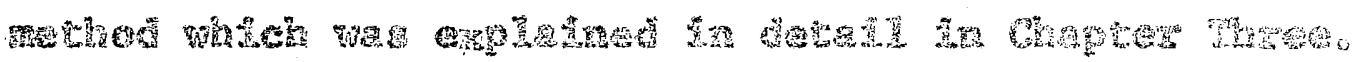

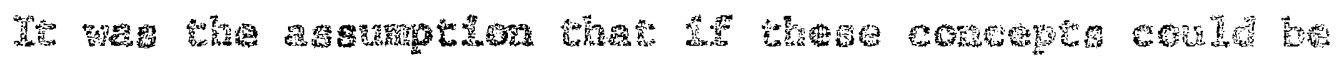

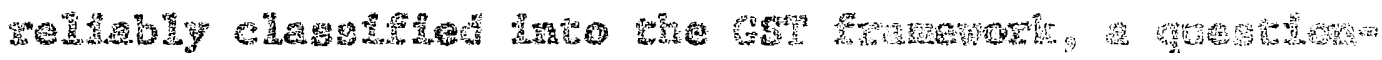

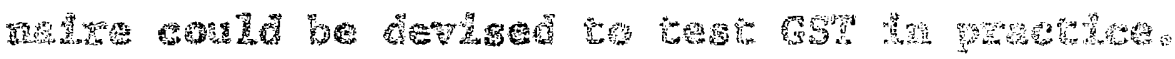

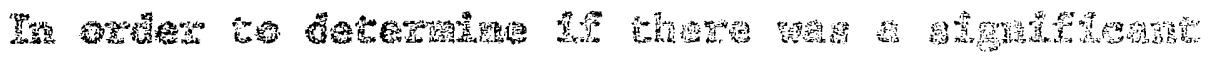

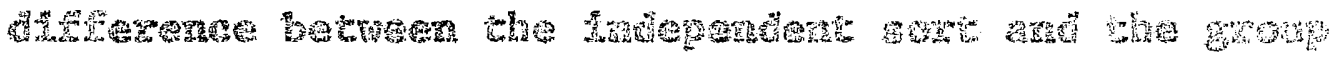

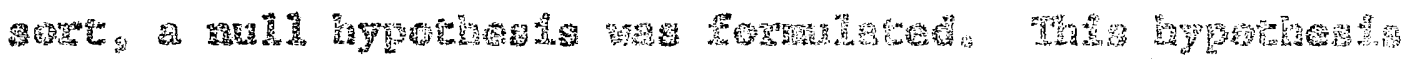

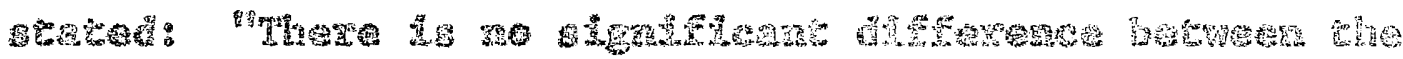

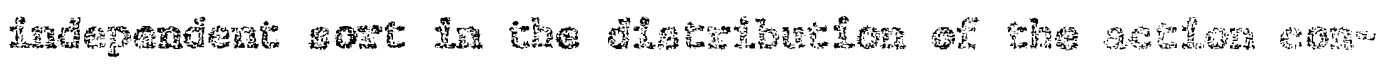

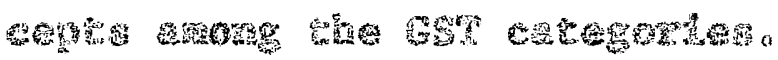

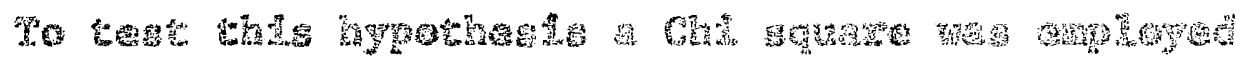

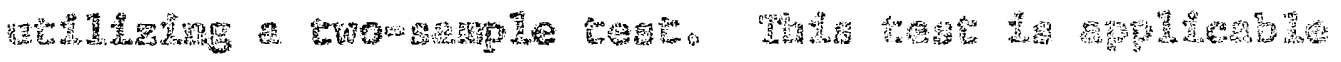

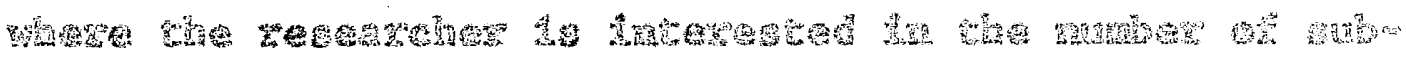
J

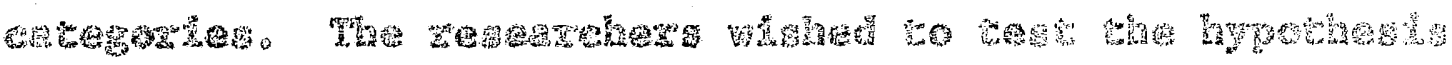

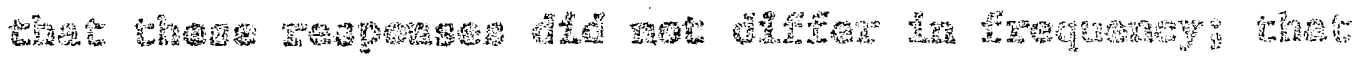




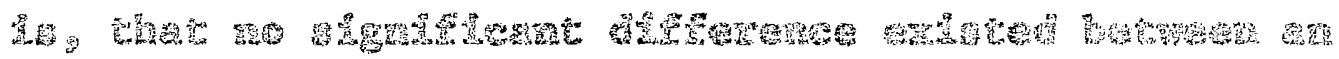

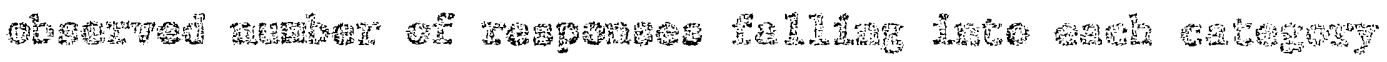

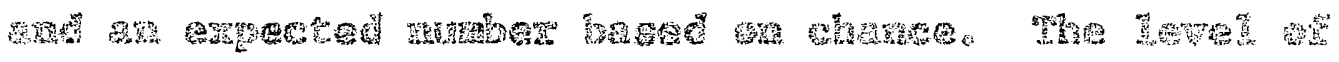
Whing

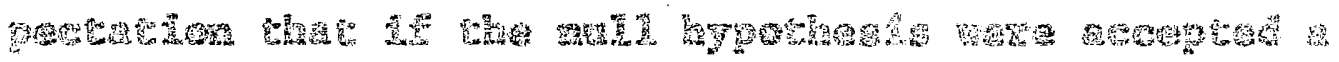

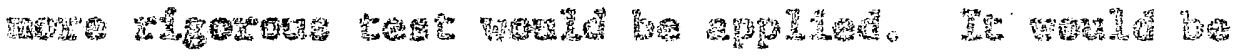

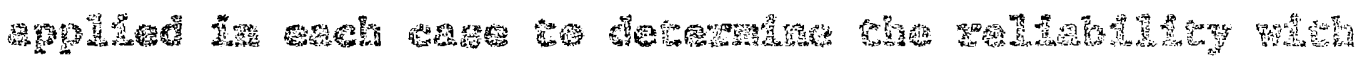

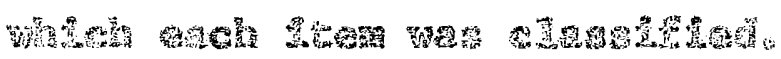

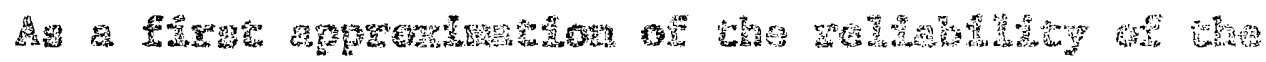
42

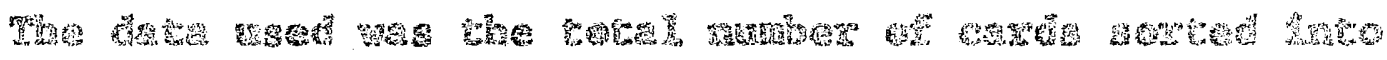

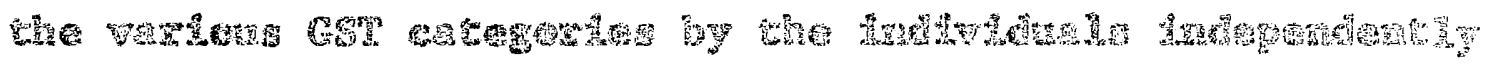

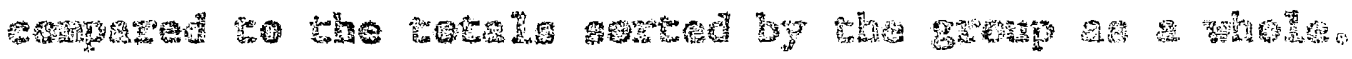

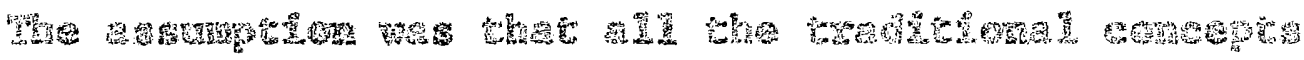

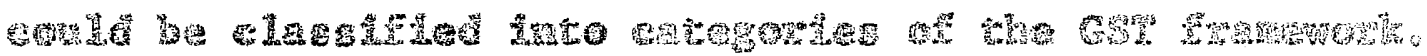

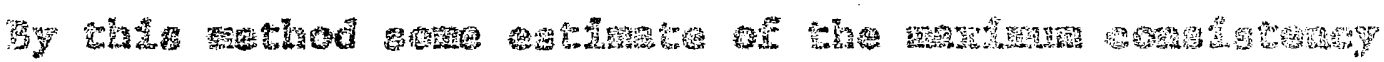

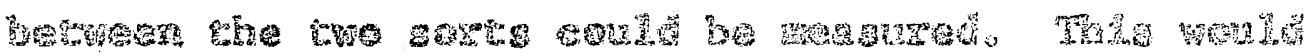

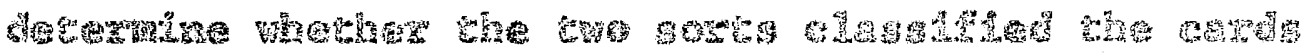

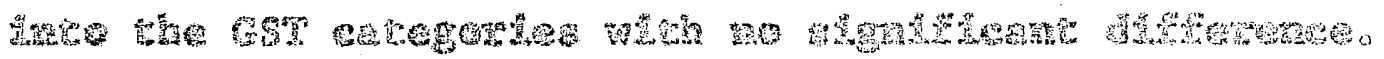

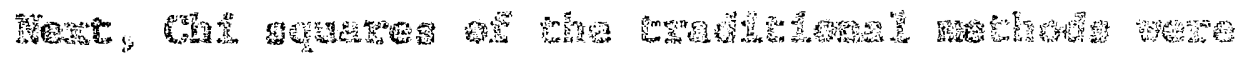

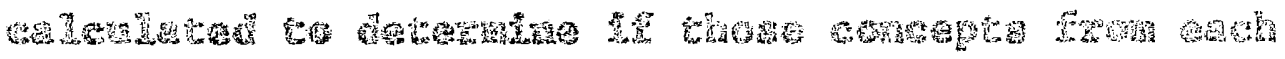

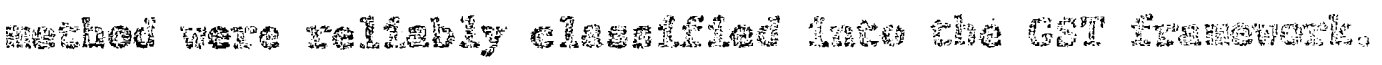

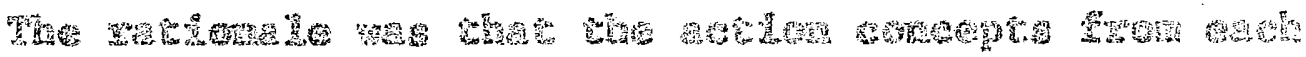
Thad

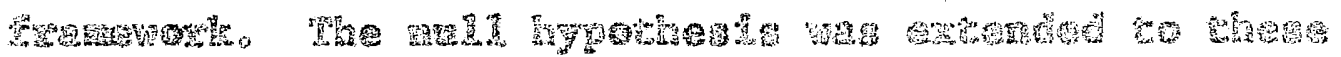

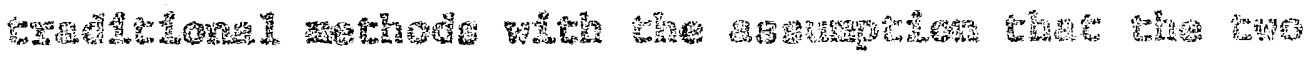




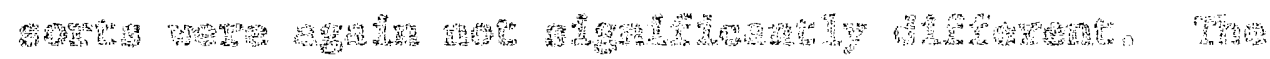

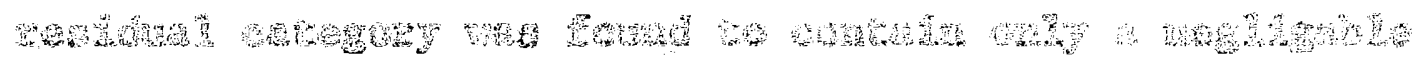
Ther

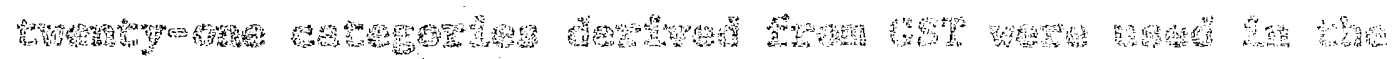

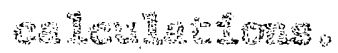

ntwa

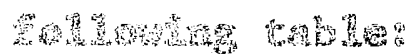

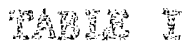

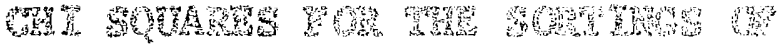

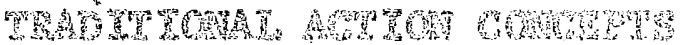

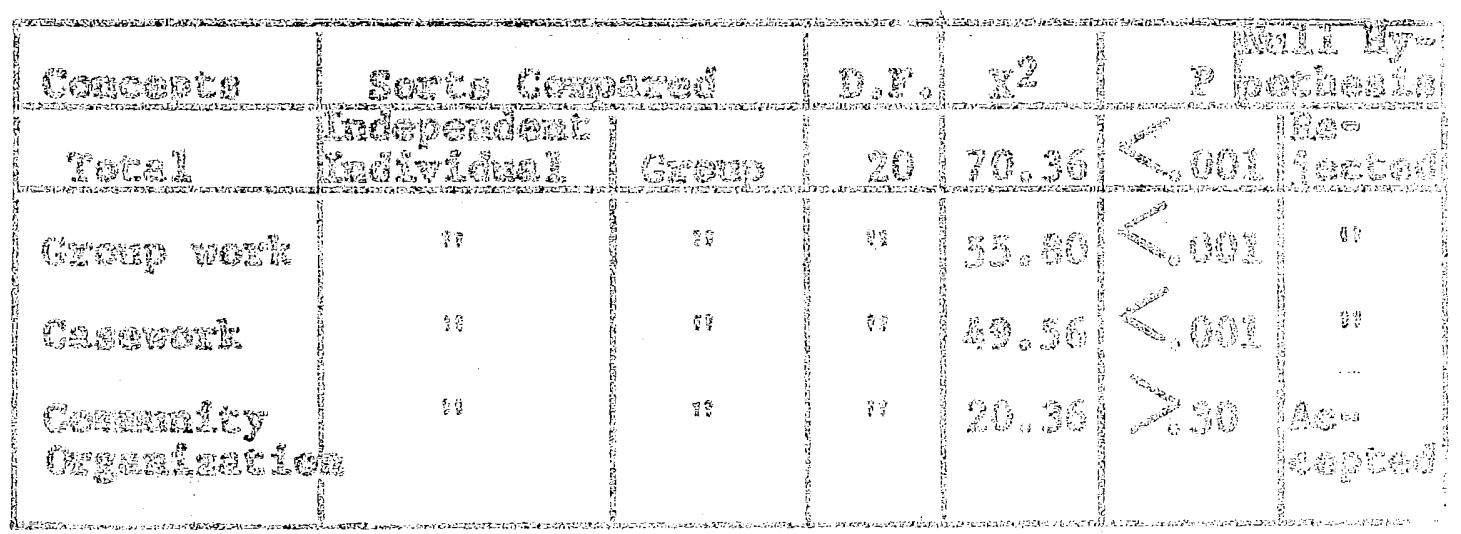

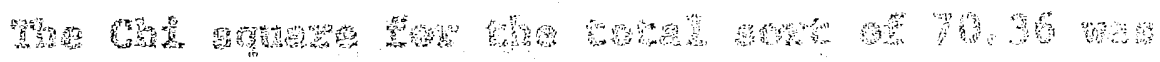

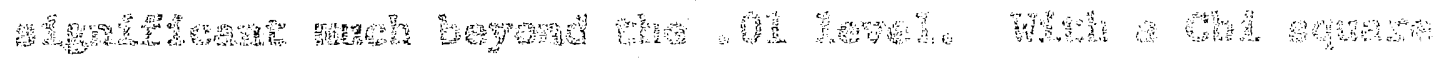

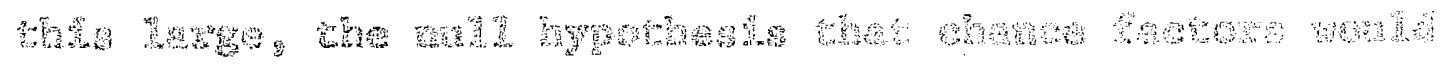

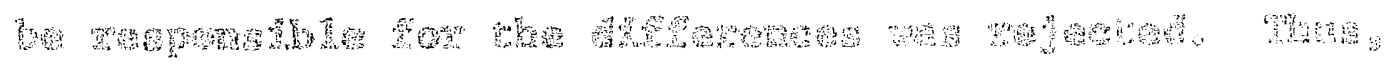

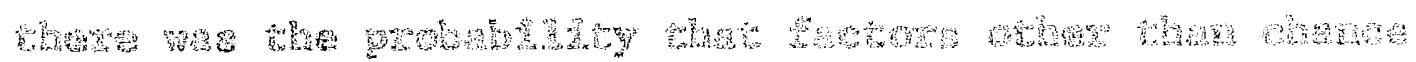

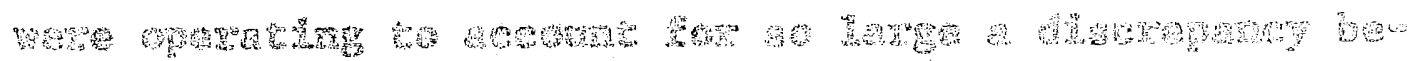

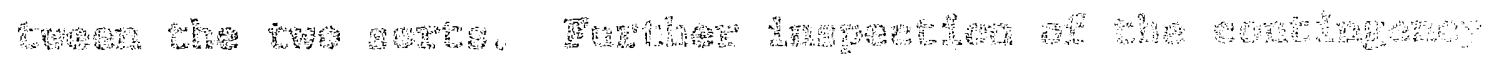

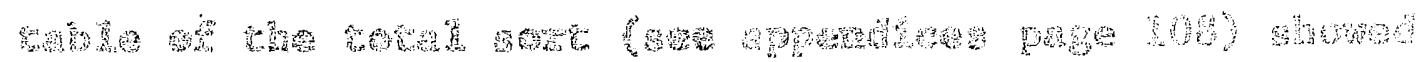




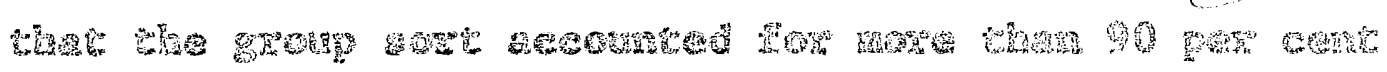

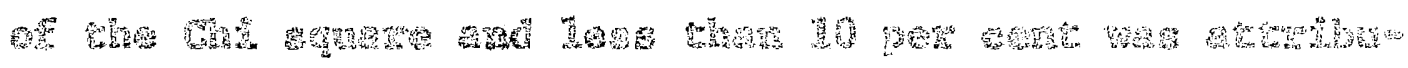

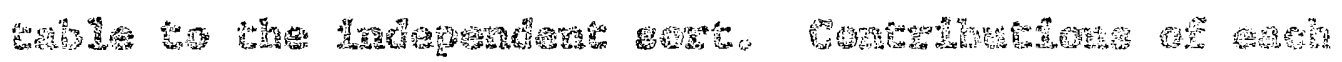

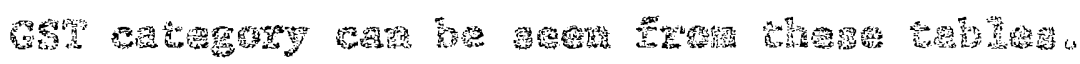

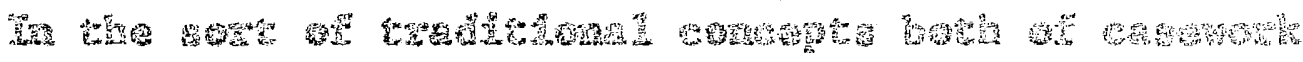

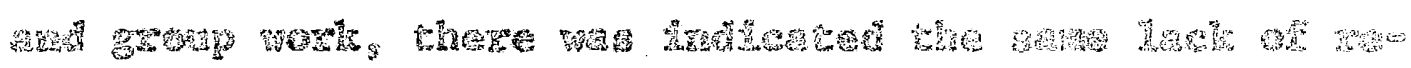

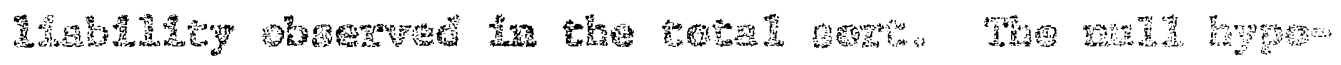

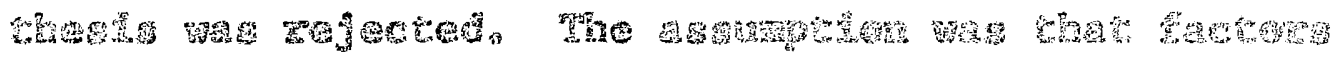

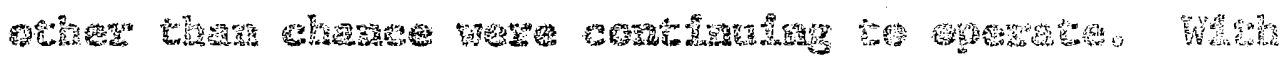

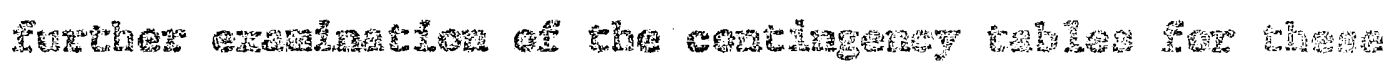

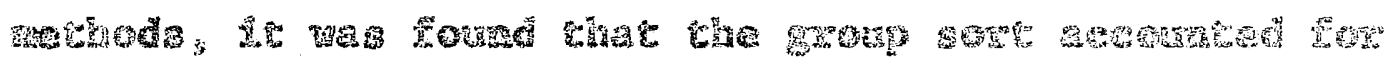

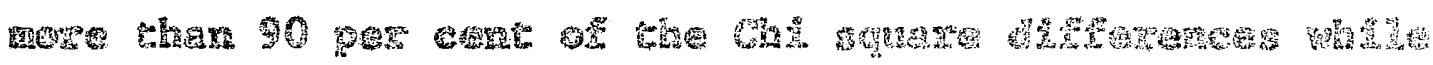

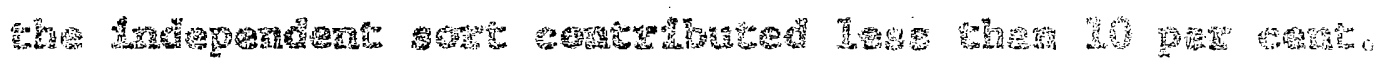

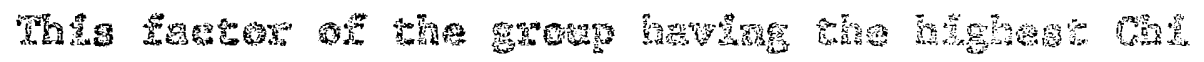

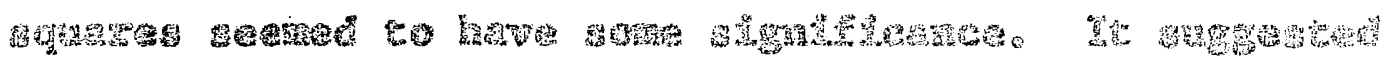

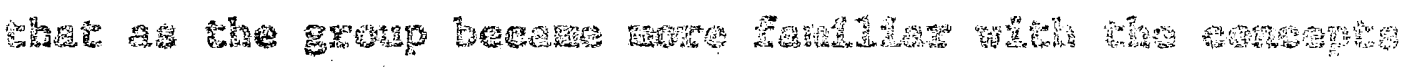

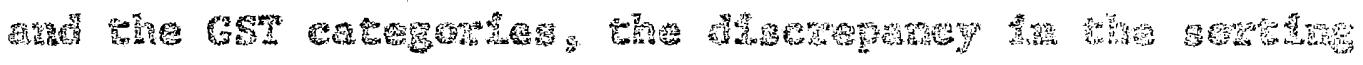

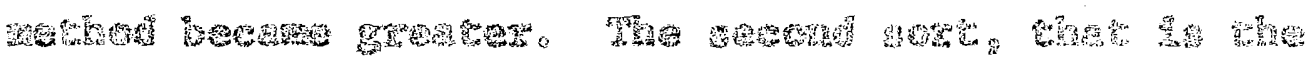

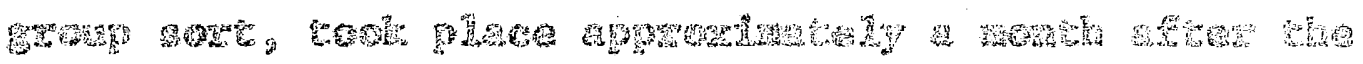

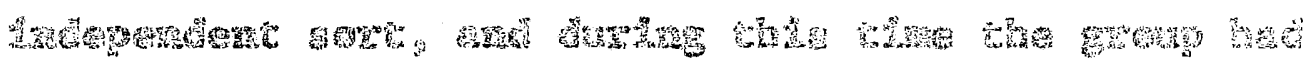

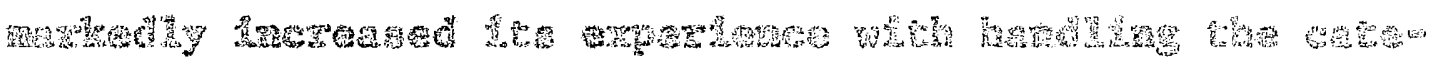

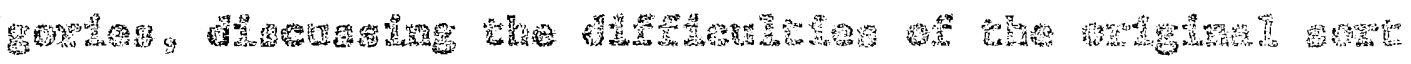

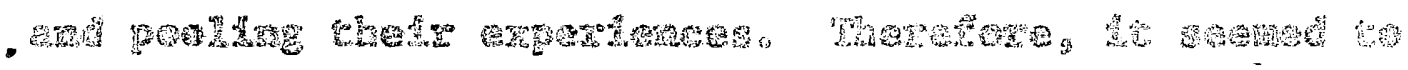

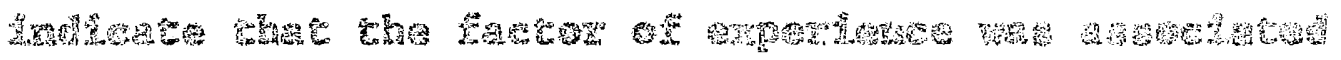

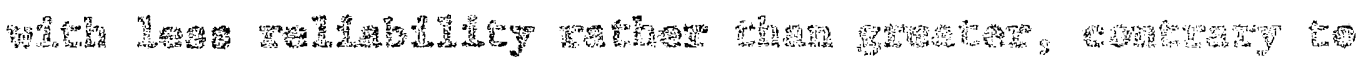
4 


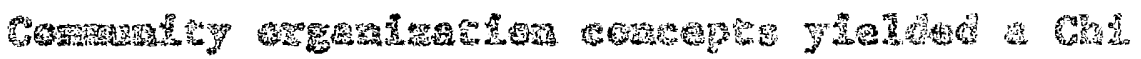

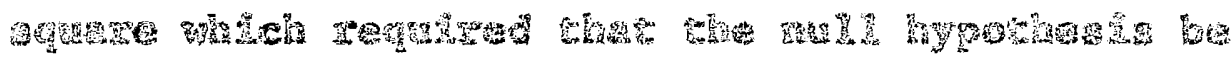

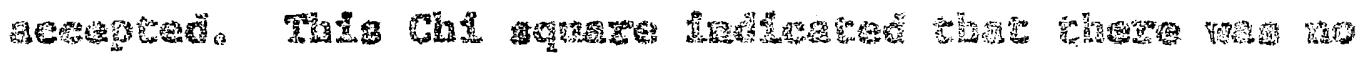

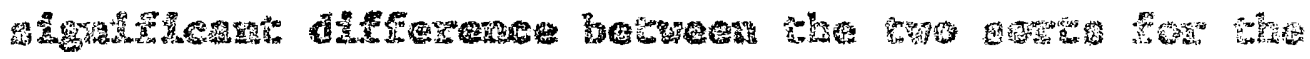

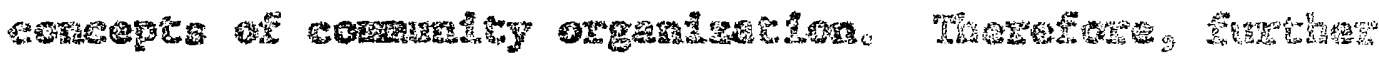

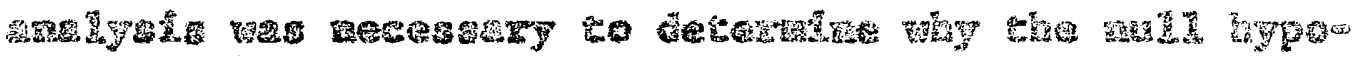

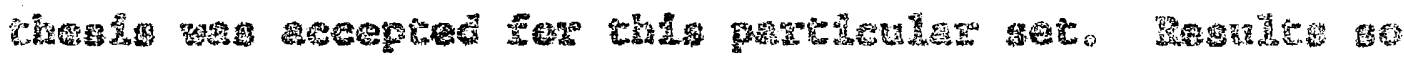

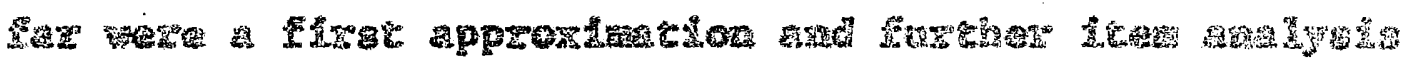

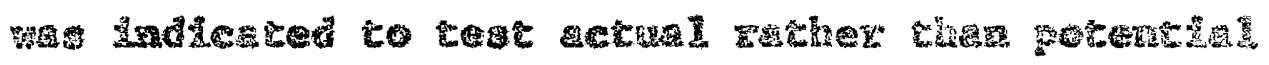
zedab 225 tso

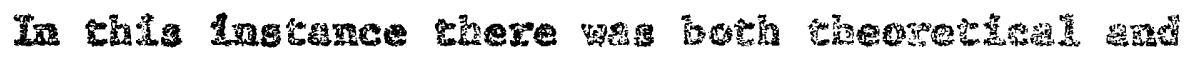

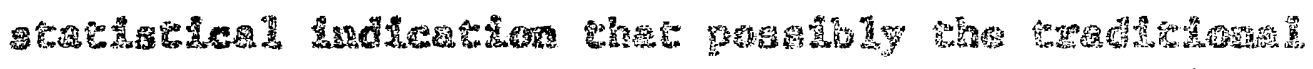

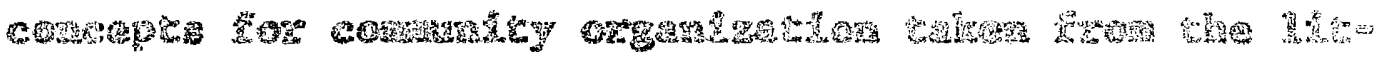

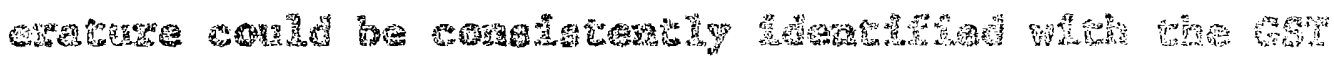

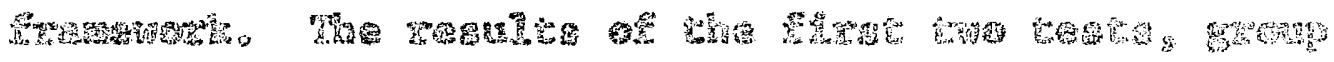

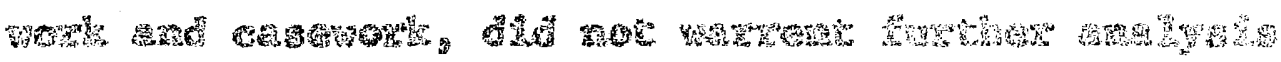

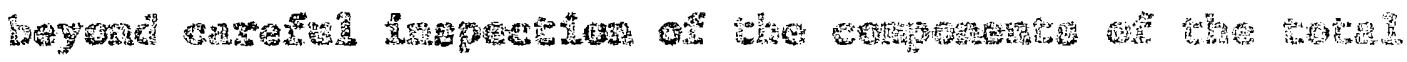

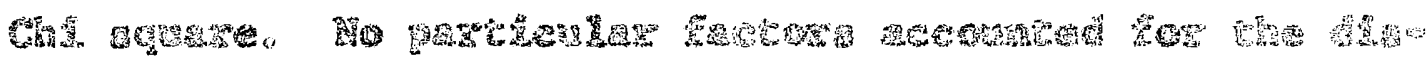
Wryox

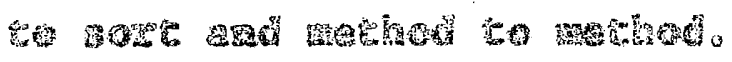

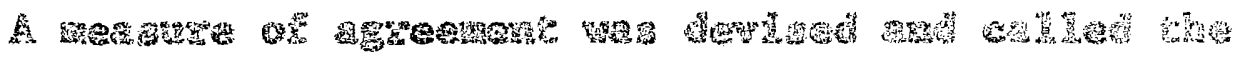

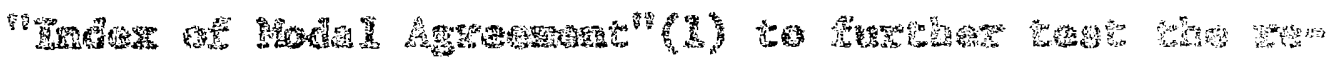

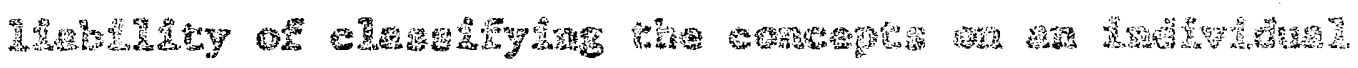

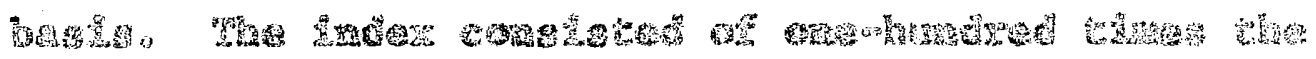

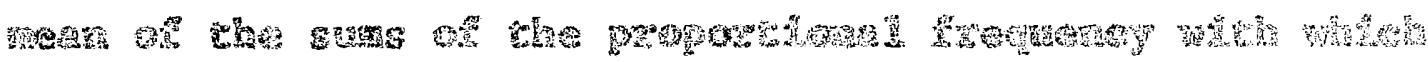

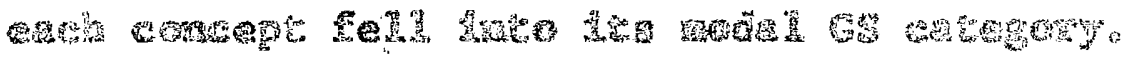




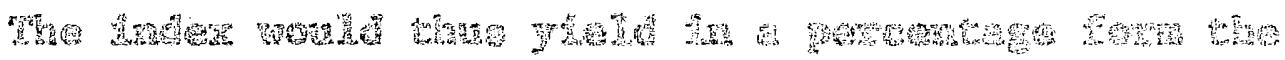

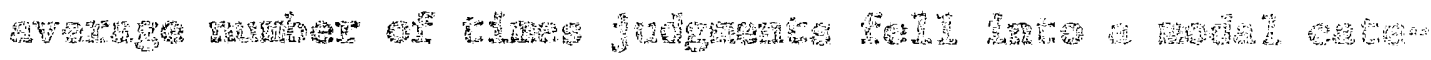

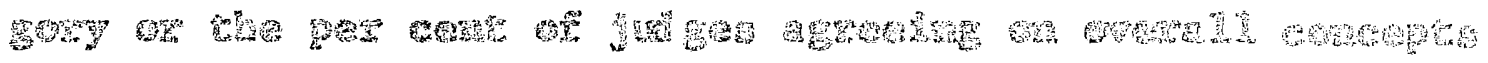

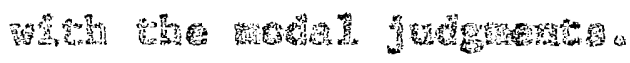

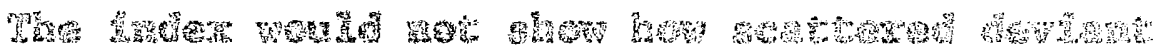

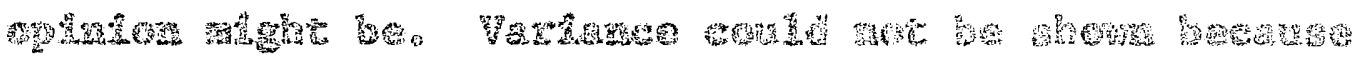

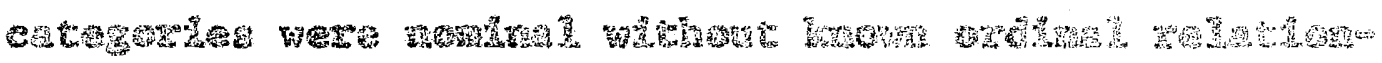

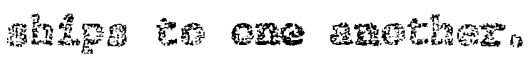

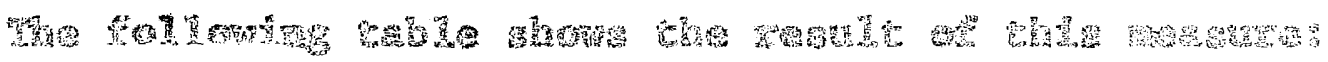

ThA

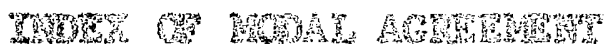

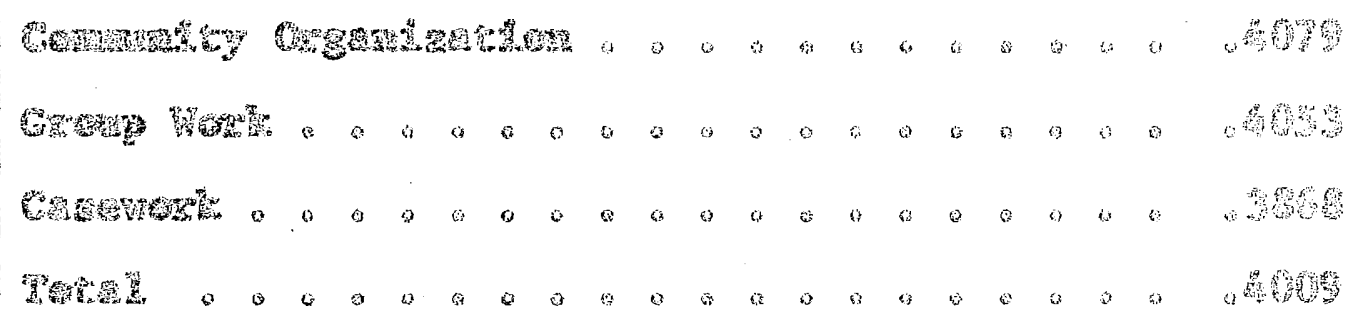

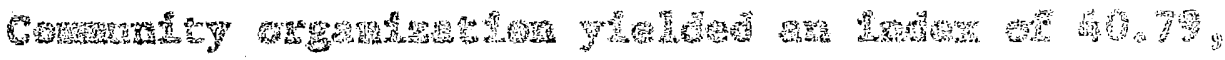

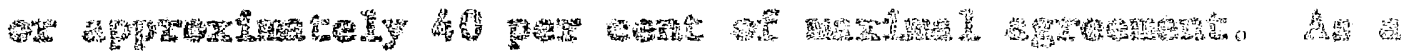

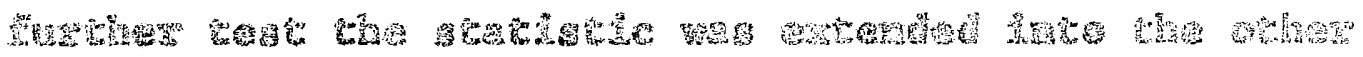

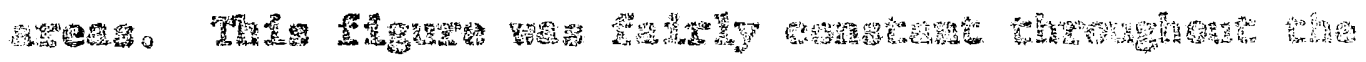

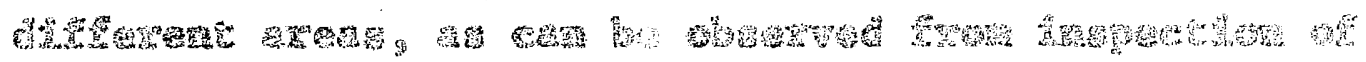

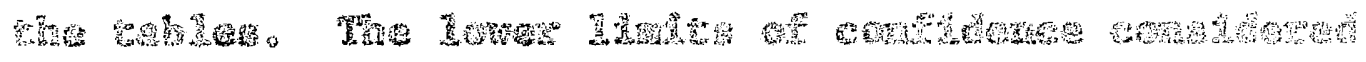

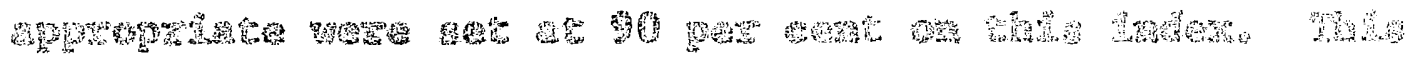

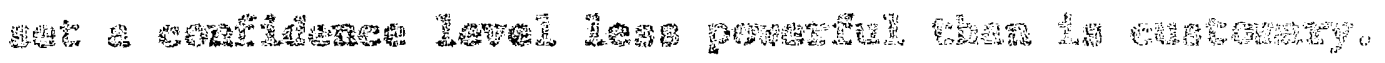




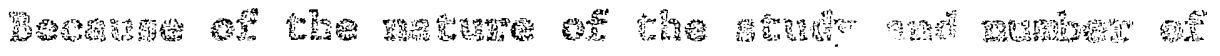

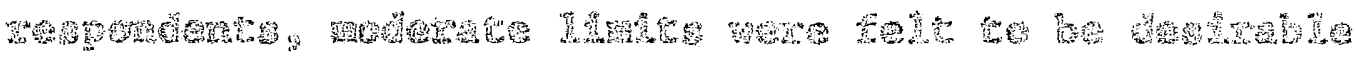

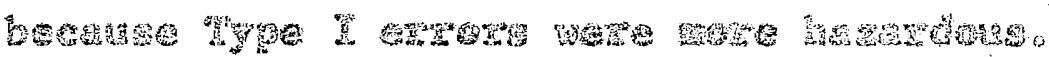

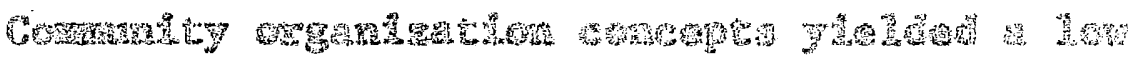

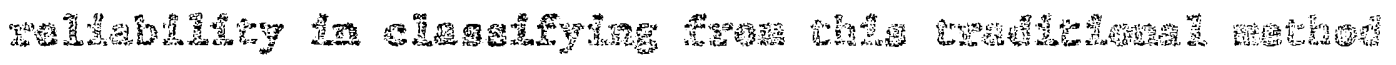
Ith

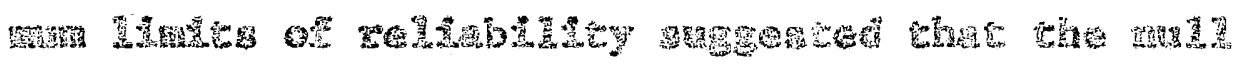

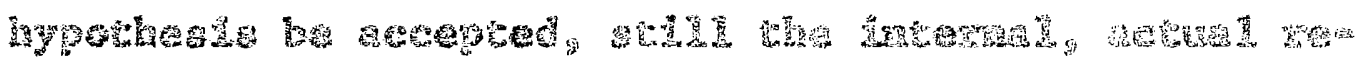

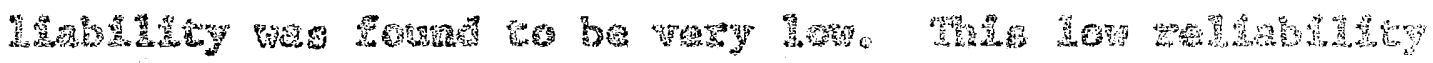

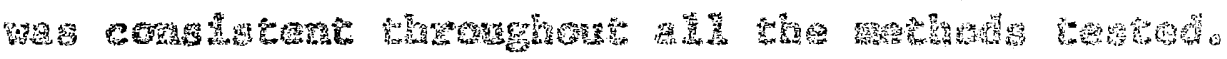

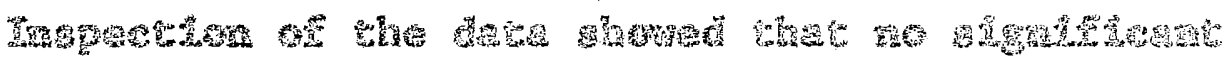

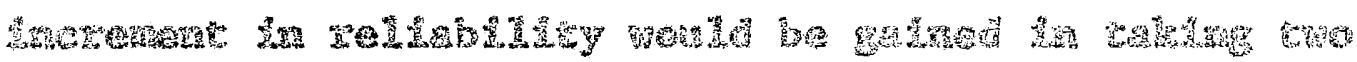

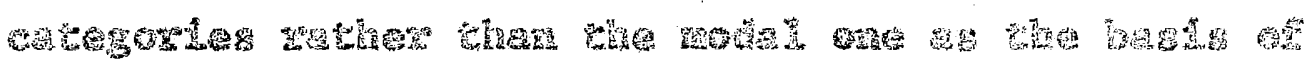

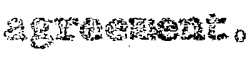

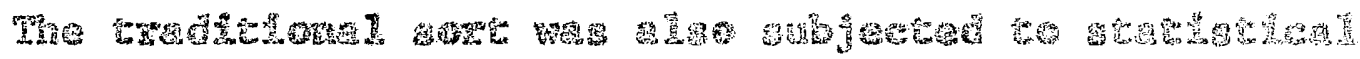

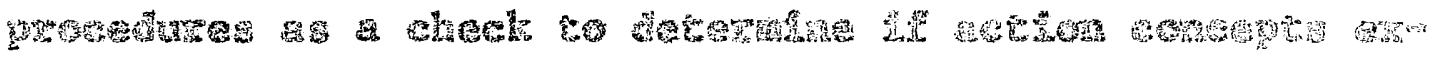

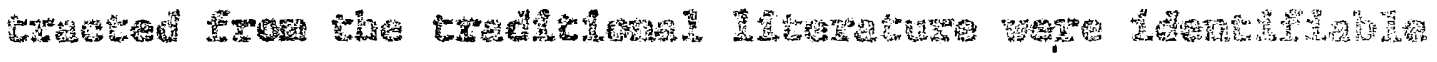

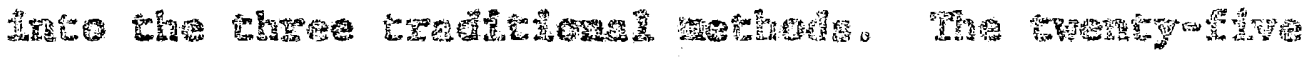

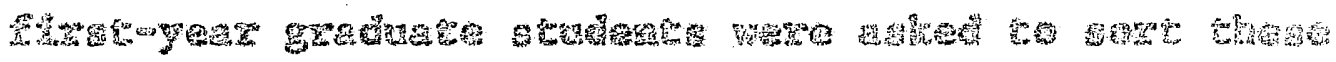

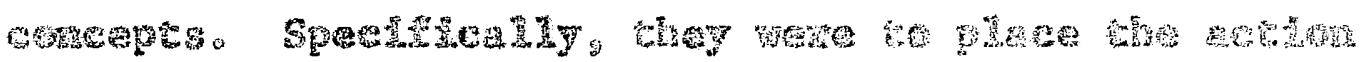

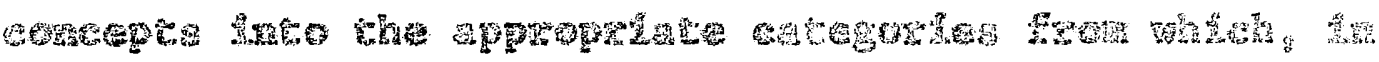
5

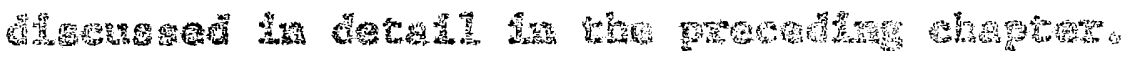

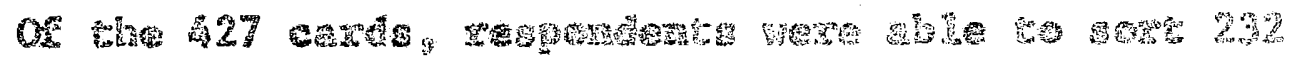

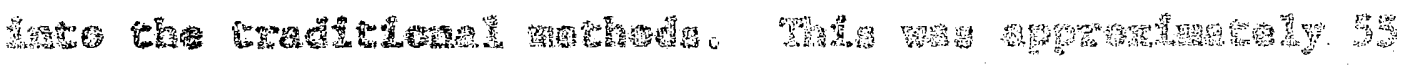

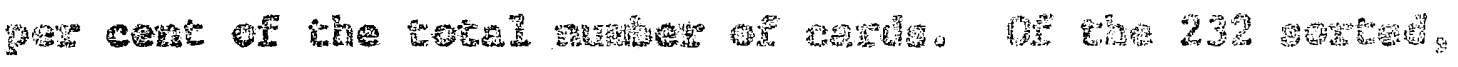

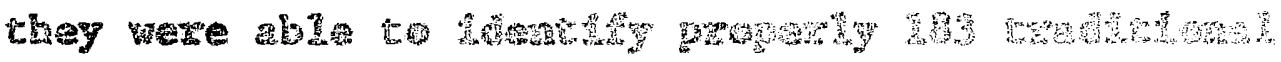




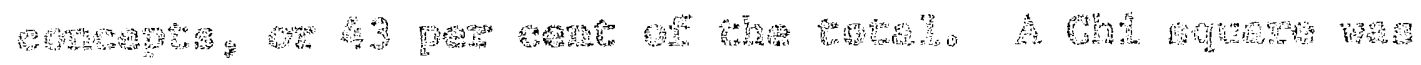

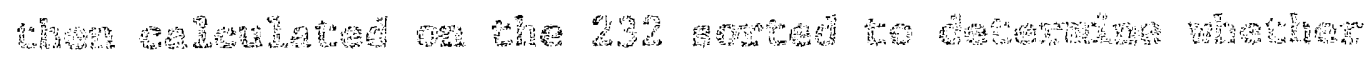

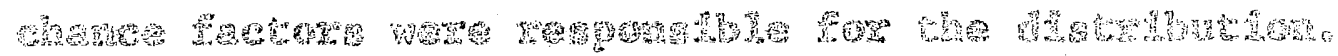

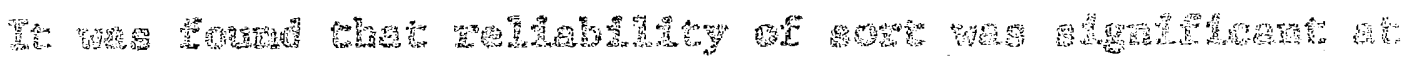

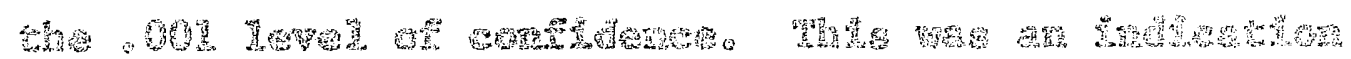

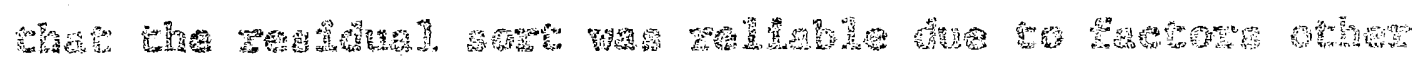

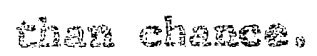

Ot .

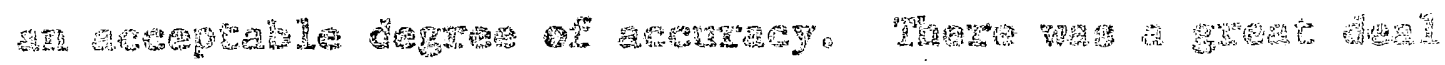

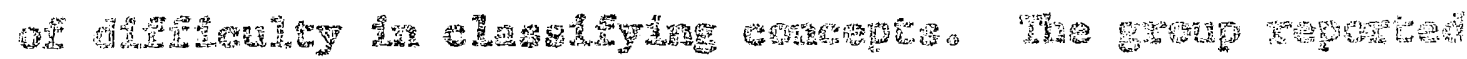

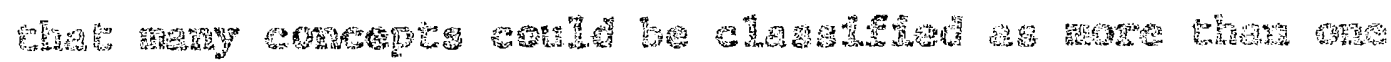

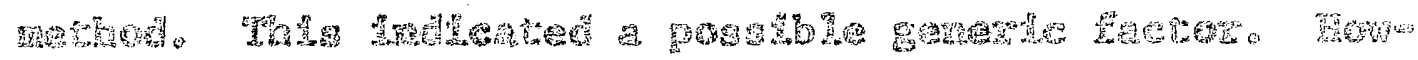

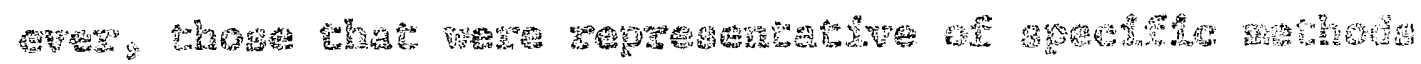

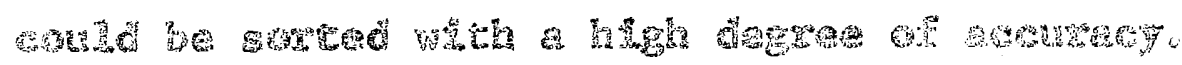

in a d a

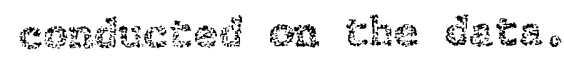

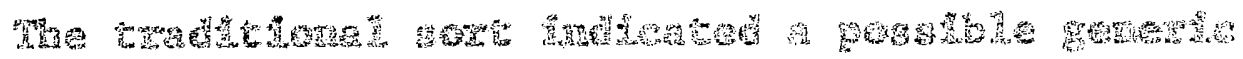

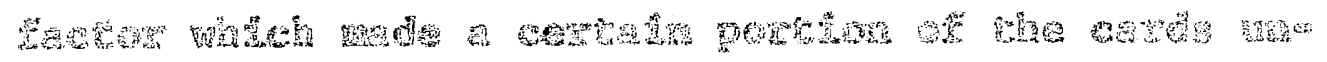

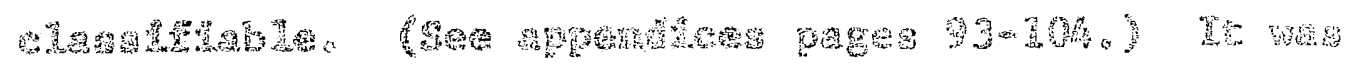

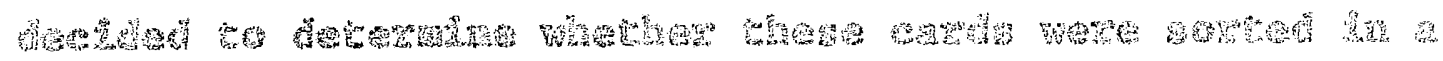

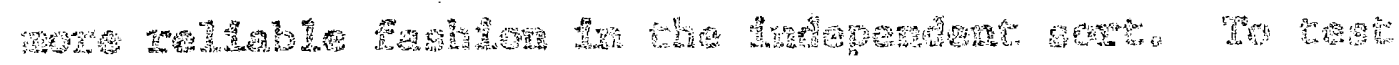

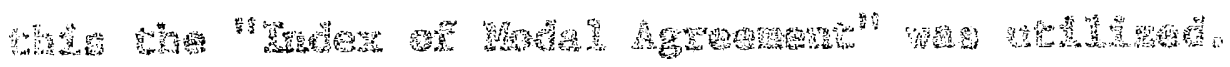

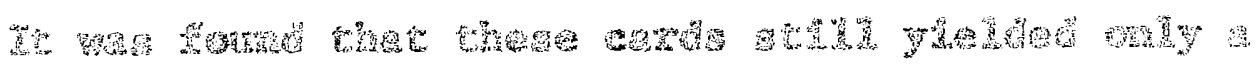

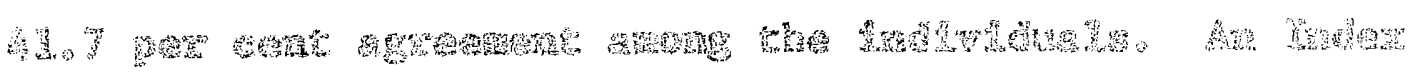

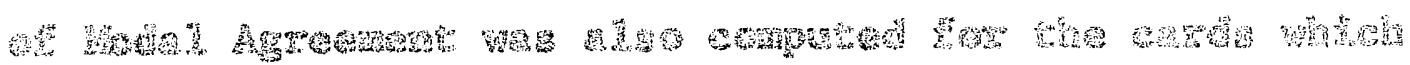




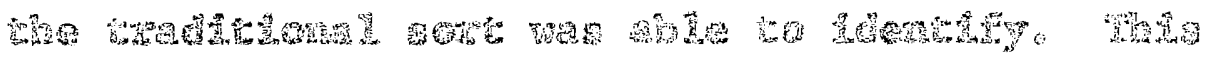

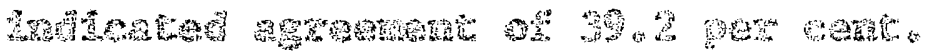

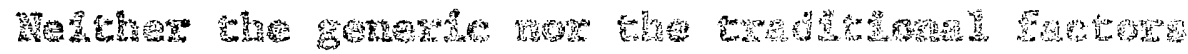

f

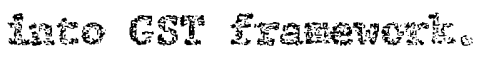

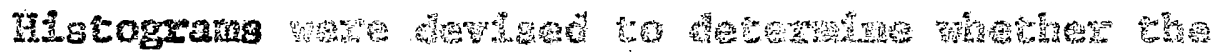

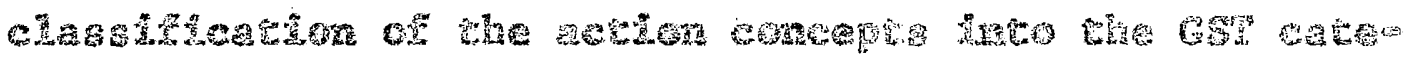

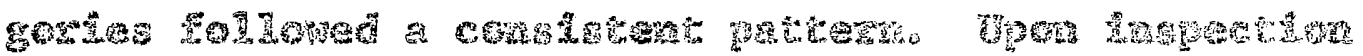

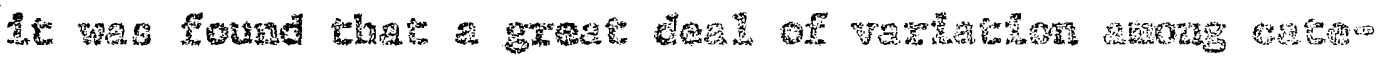

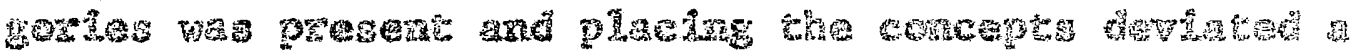

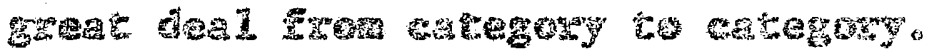

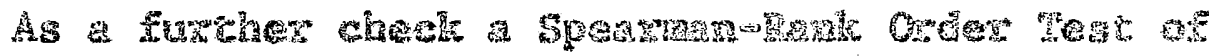

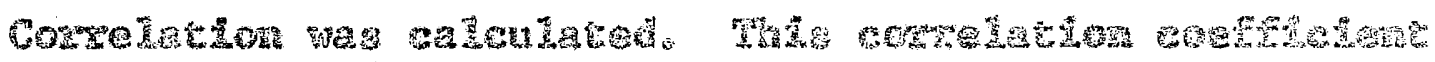

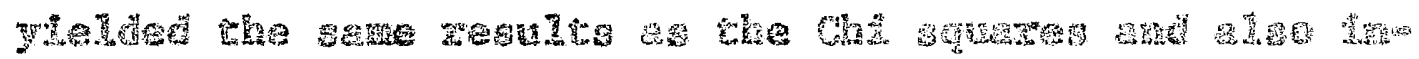

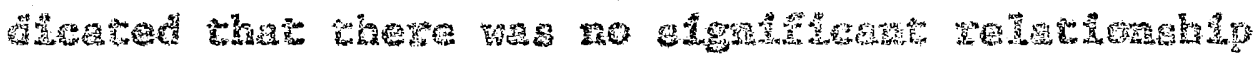

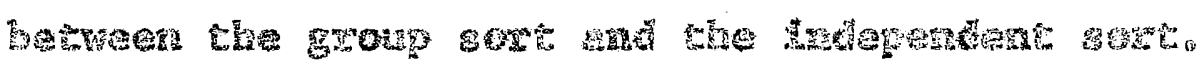

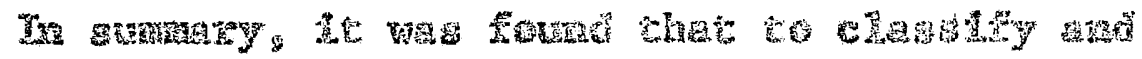

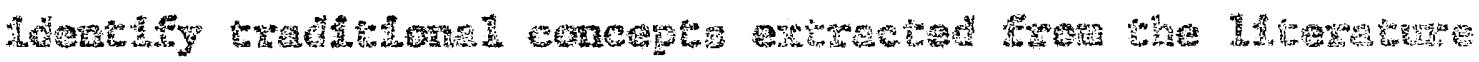

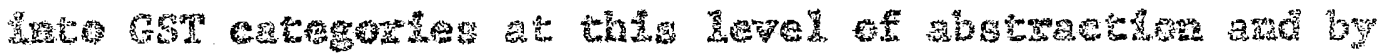

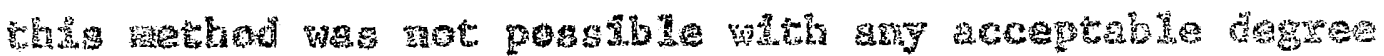

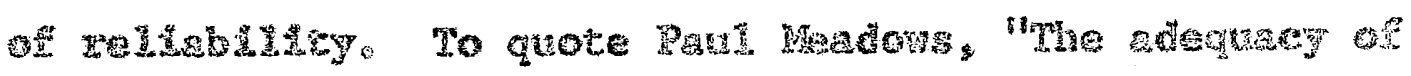

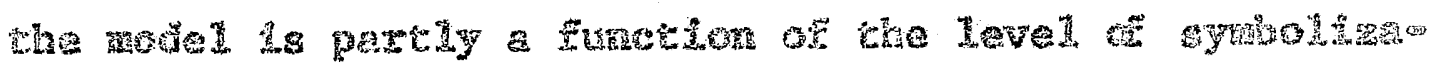

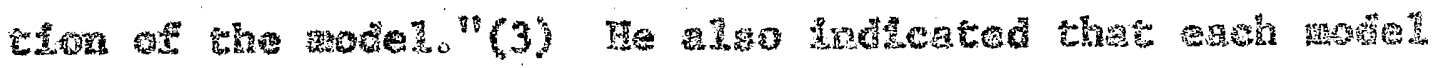

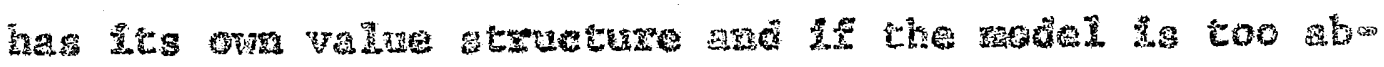

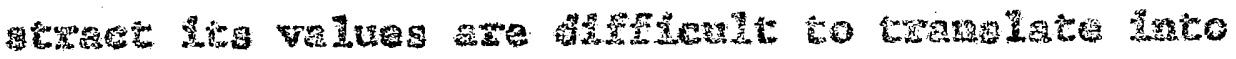

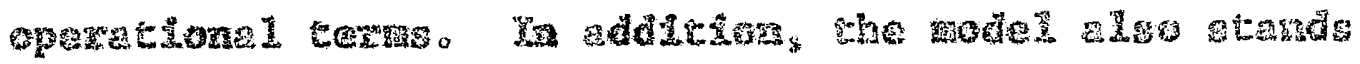




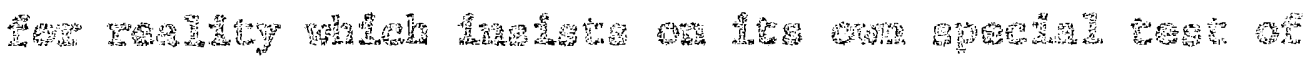

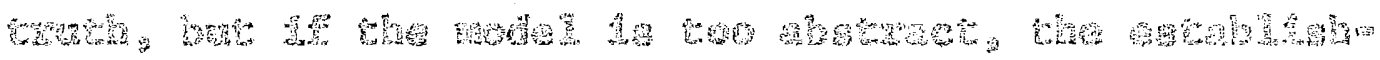

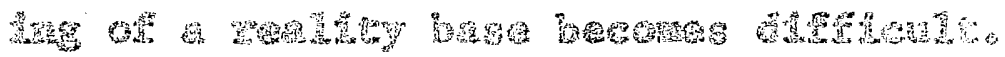

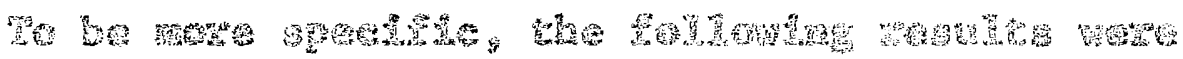
pexag a

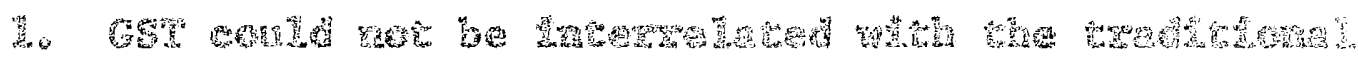

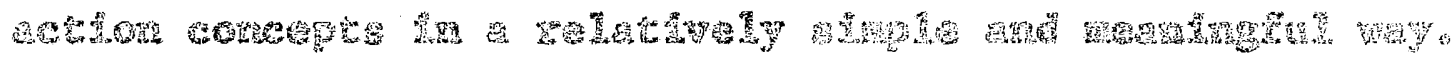

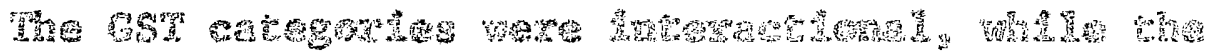

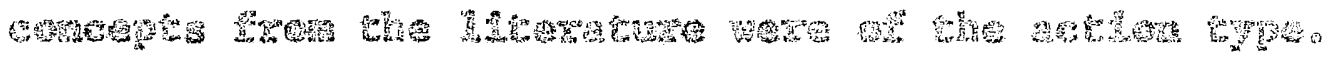

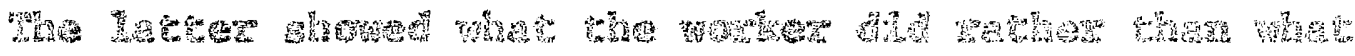

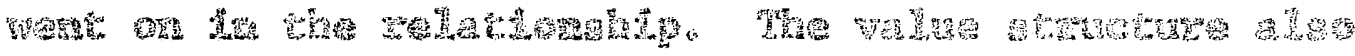
ThA

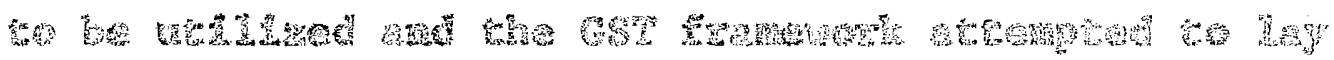

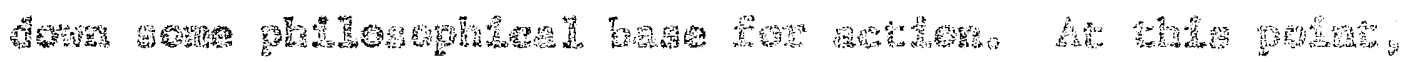

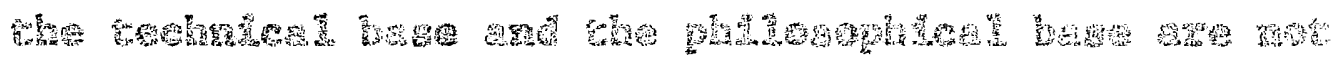

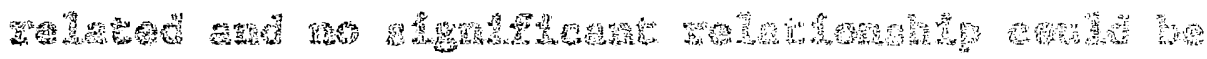

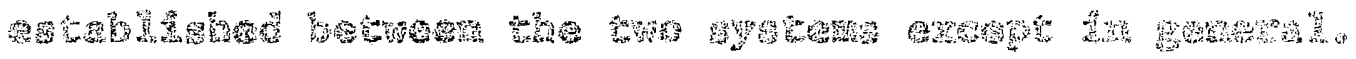

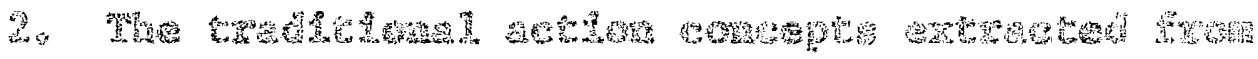

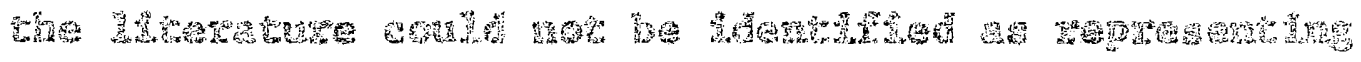

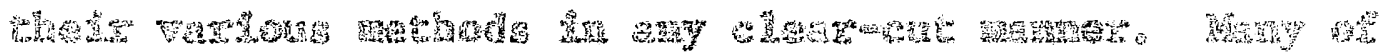

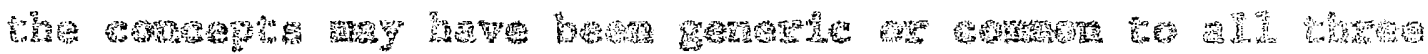

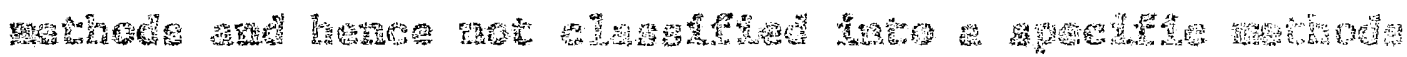

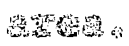

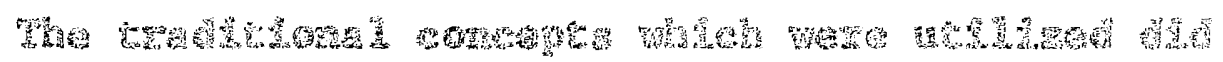

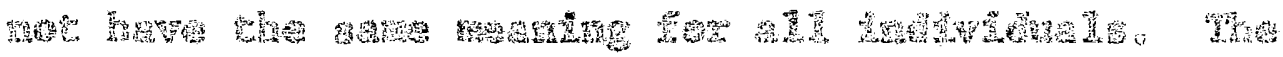
Math 


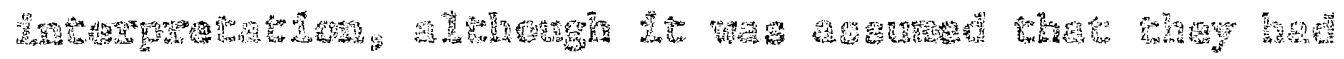

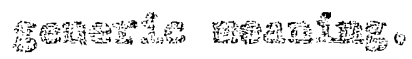

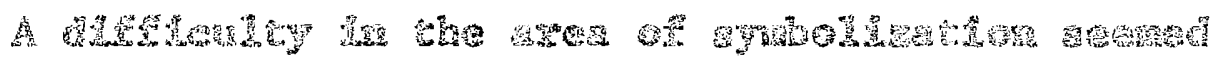

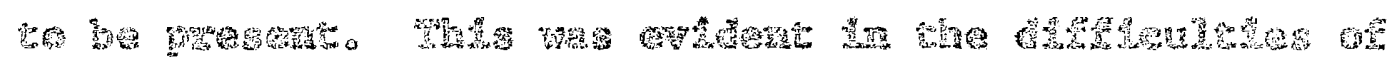

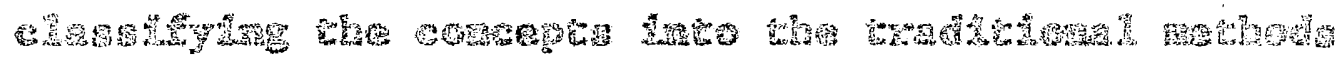

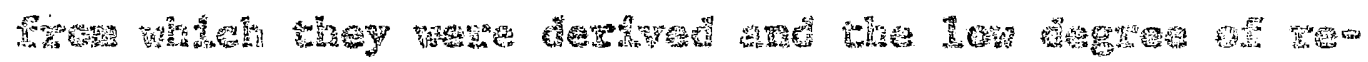

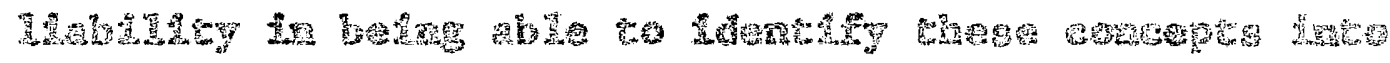

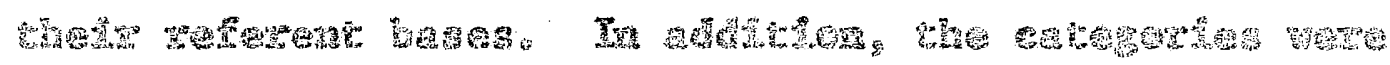

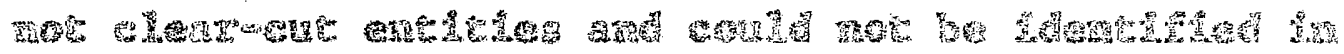

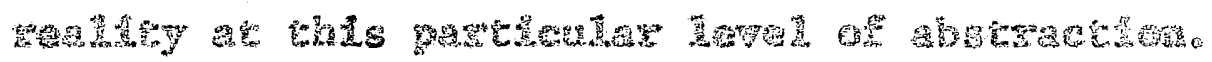

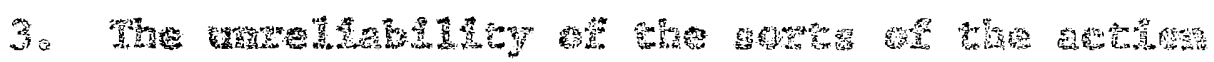

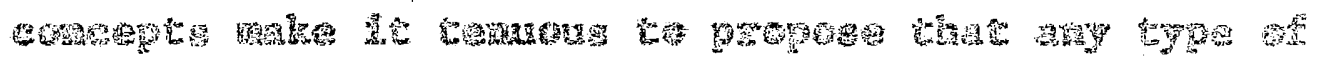

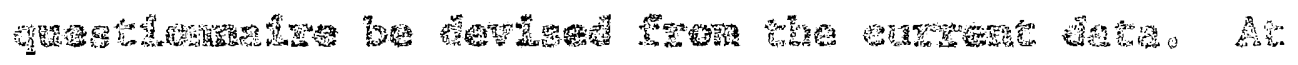

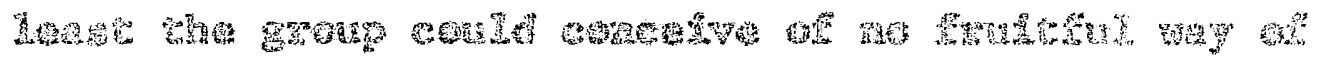
W

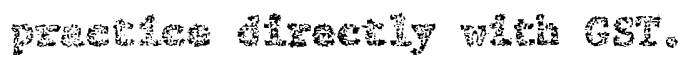

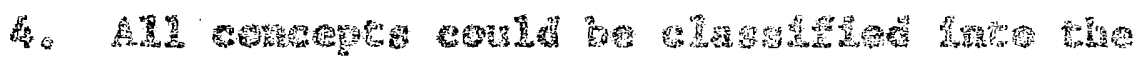

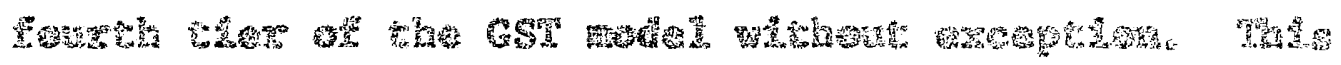

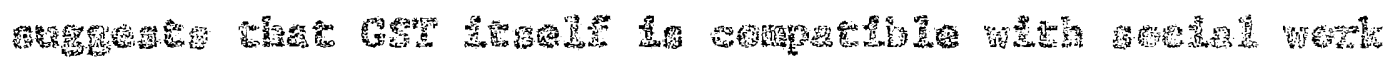

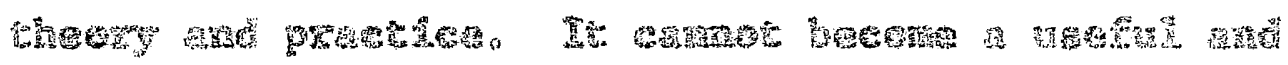

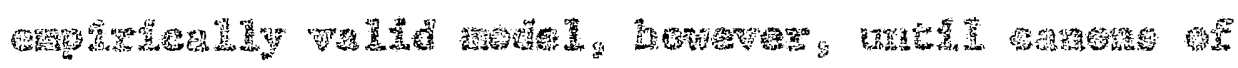

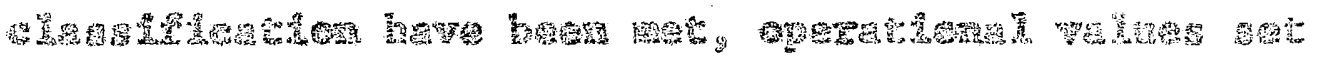
W

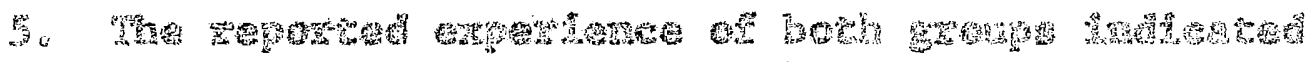

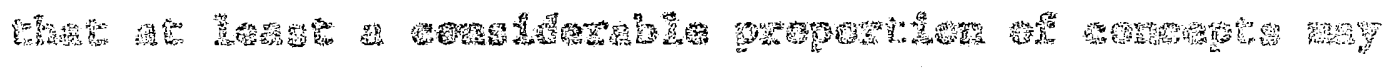

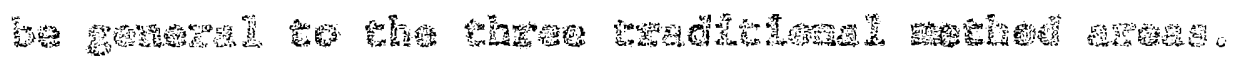




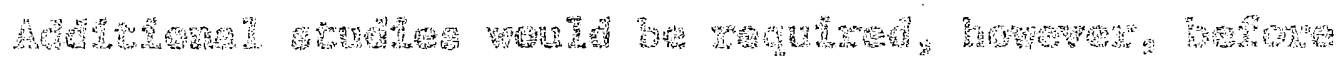

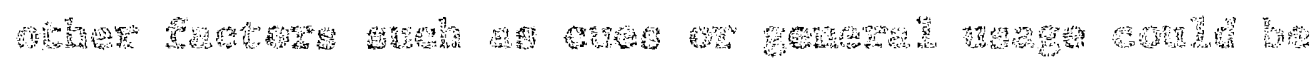

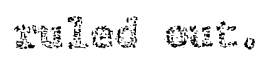

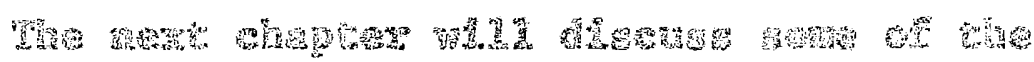
A 


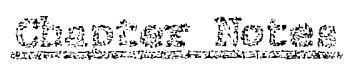

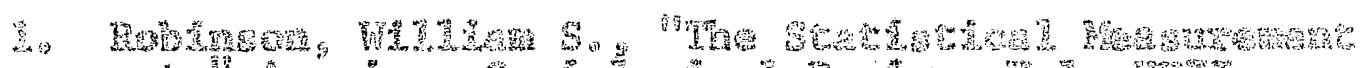

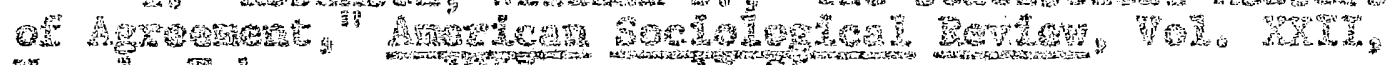

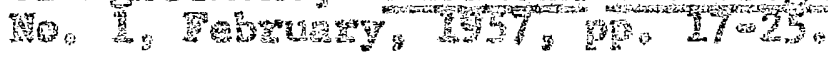

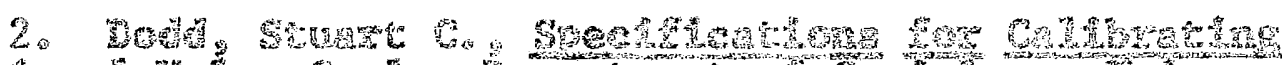
9. Wat

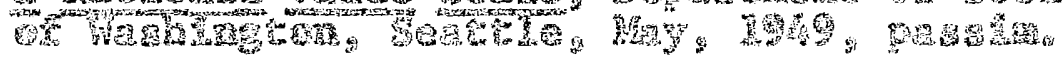

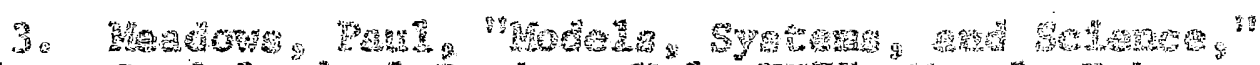

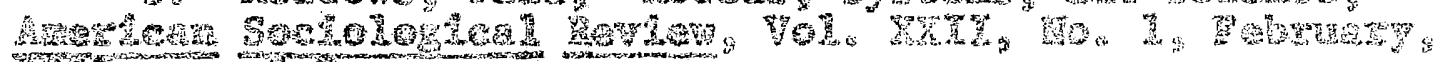

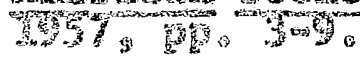




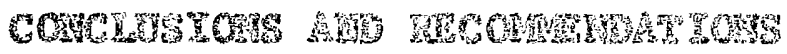

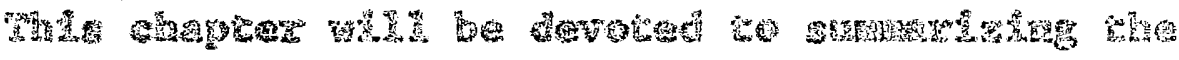

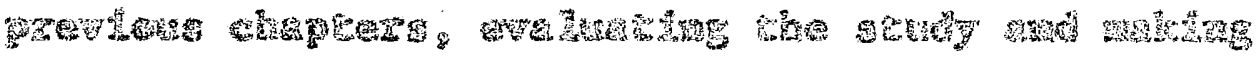

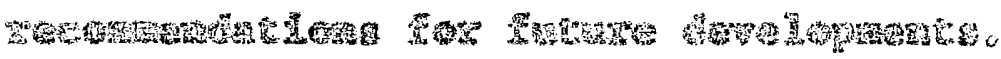

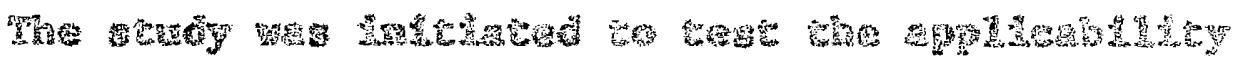

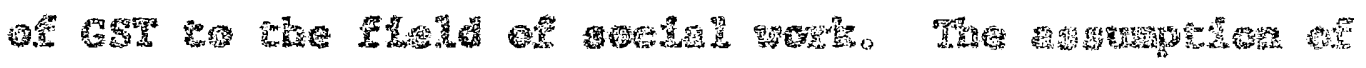

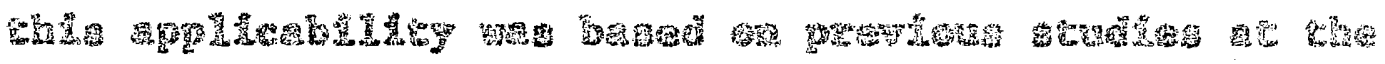

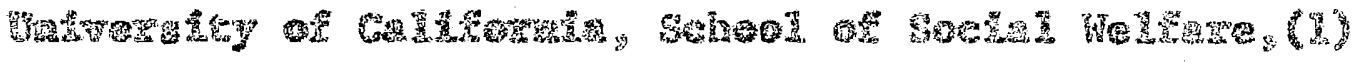

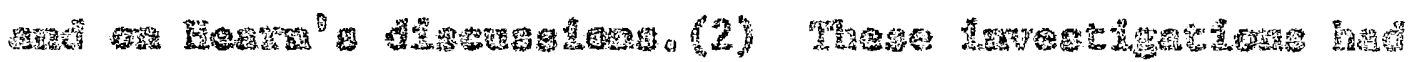

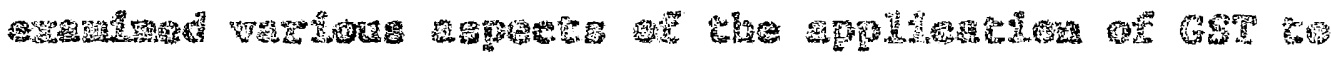

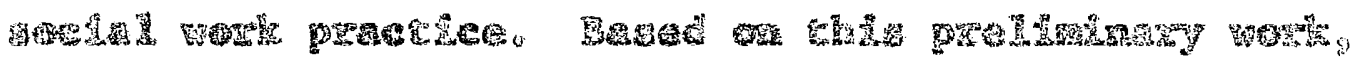

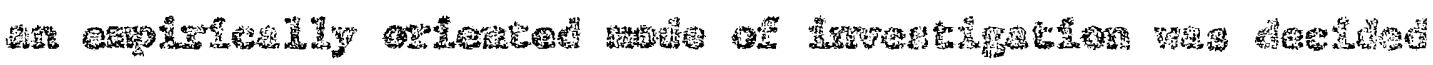
apora

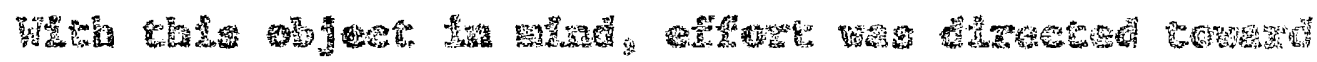

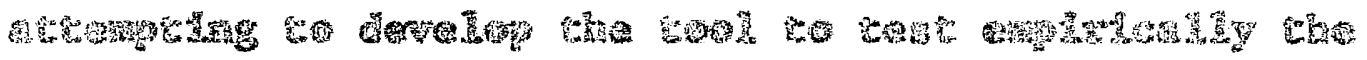

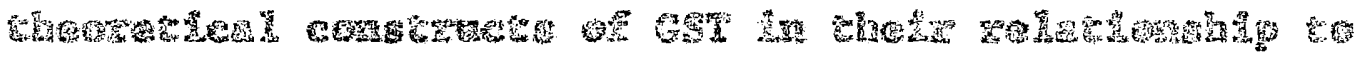
gexh

A generat

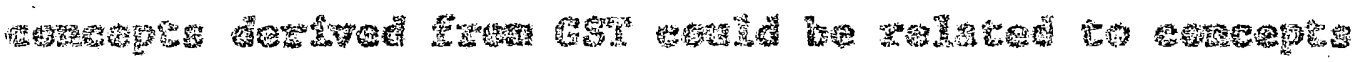

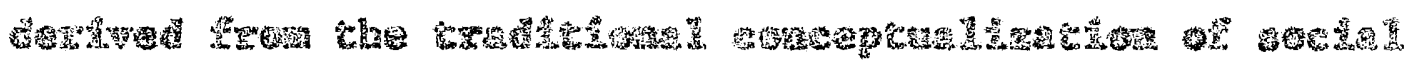

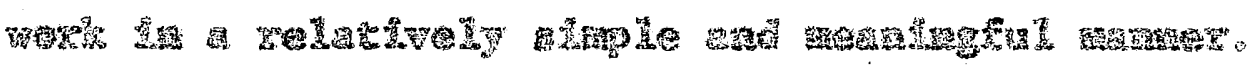

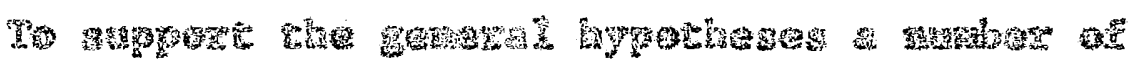
and 


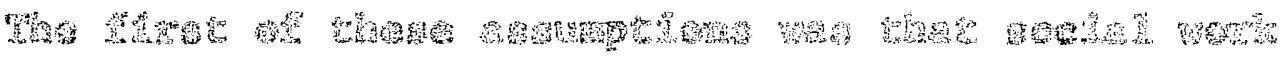

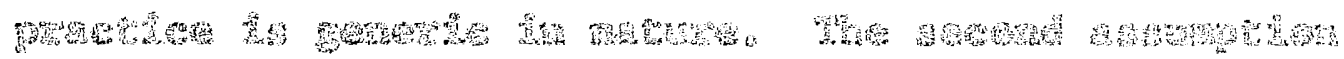

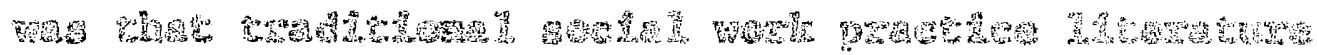
Nown

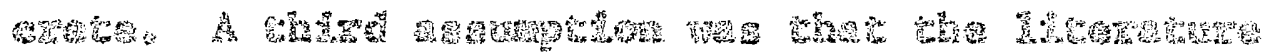

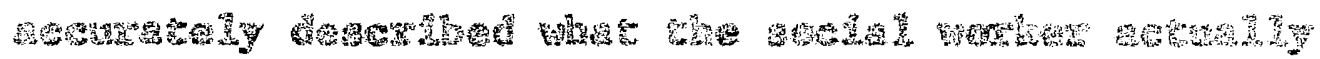
f 4y

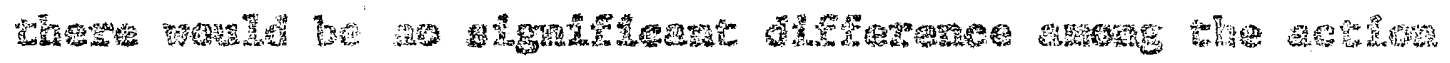

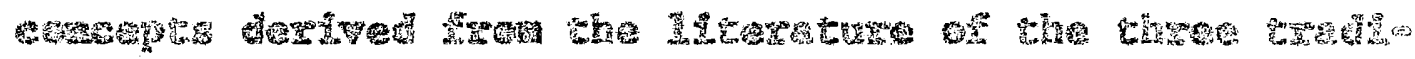

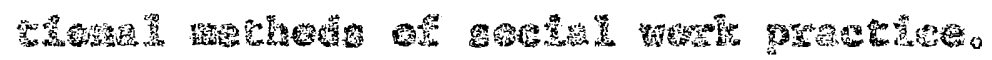

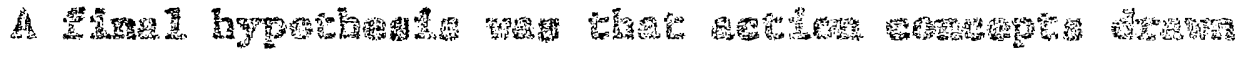

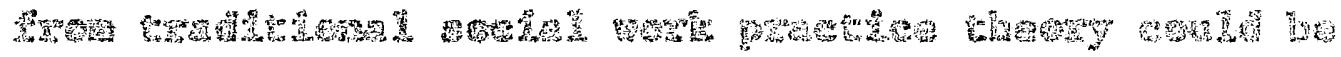

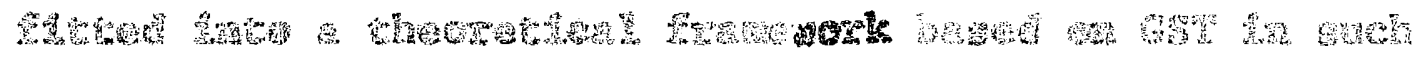

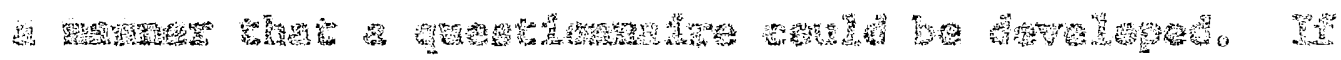

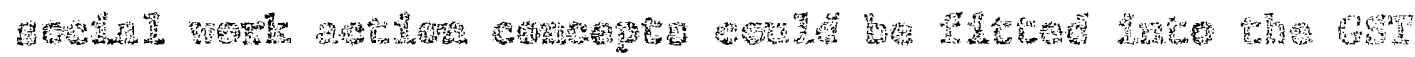

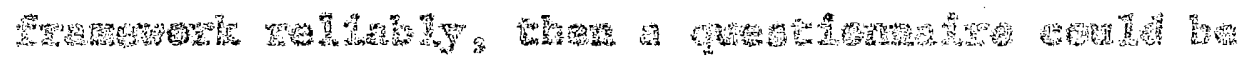

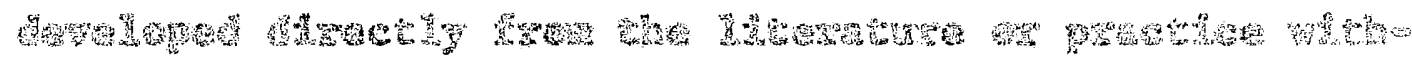

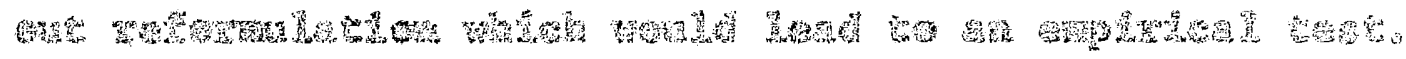

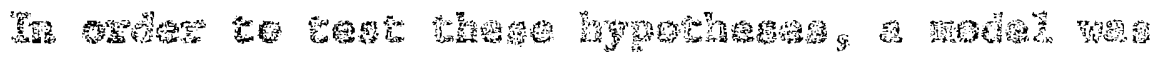
4.

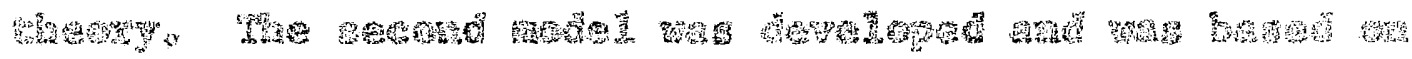

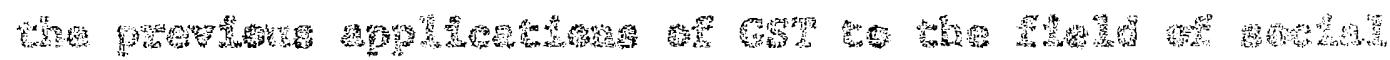

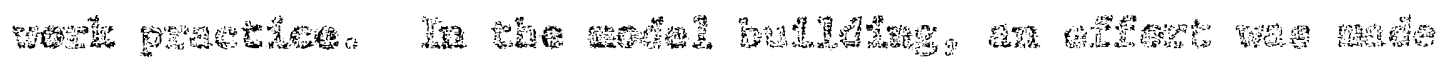

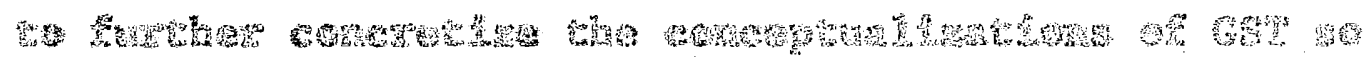

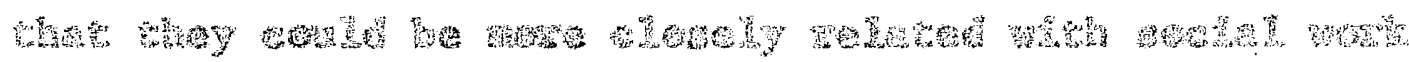

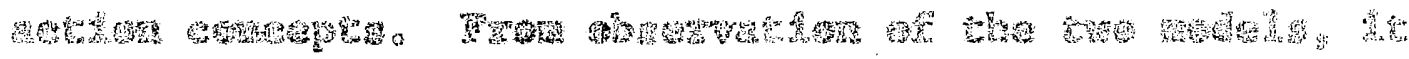




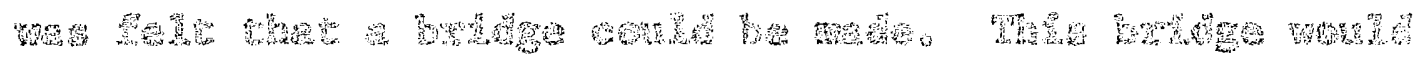

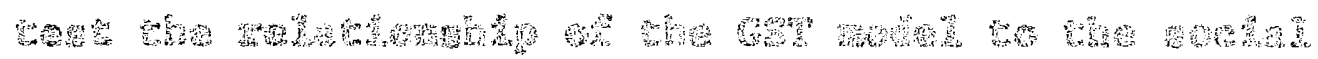

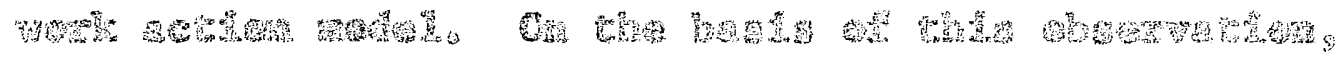

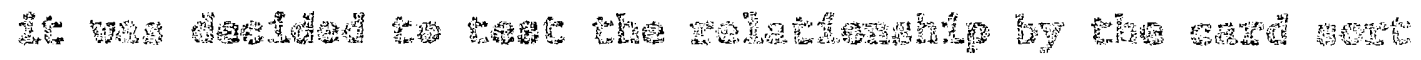
atatento

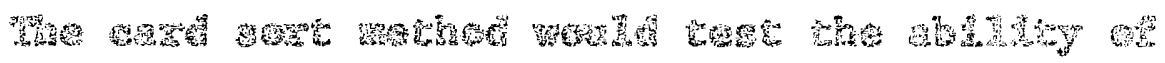
Ax

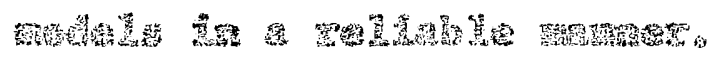

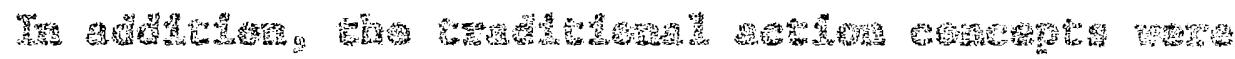

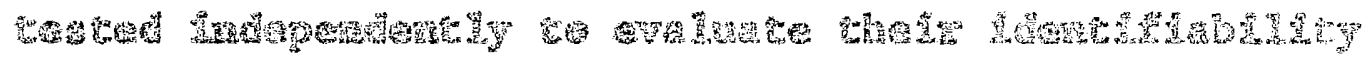

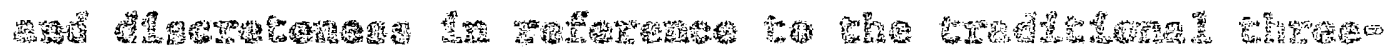

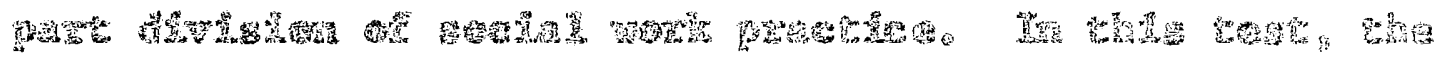

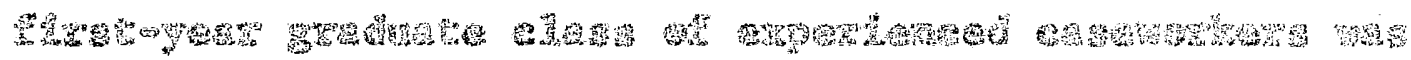

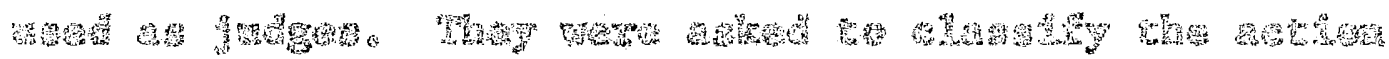

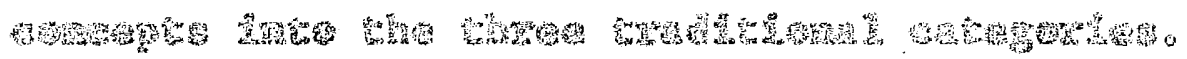

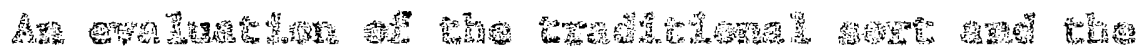

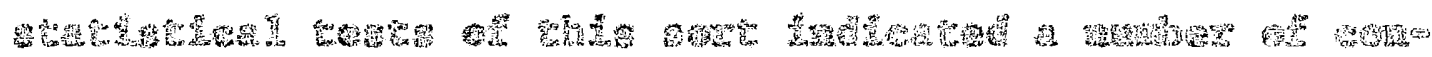

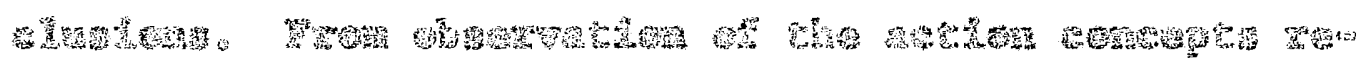
tha

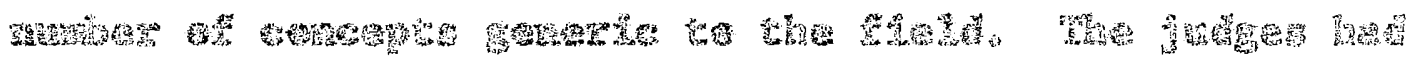

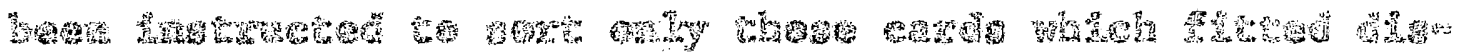

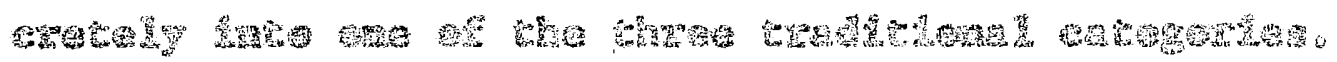

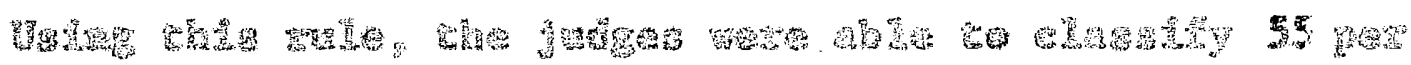

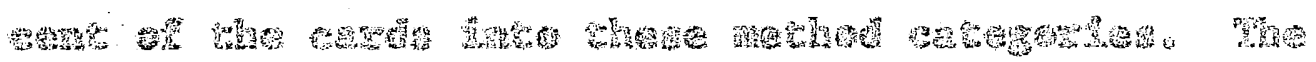

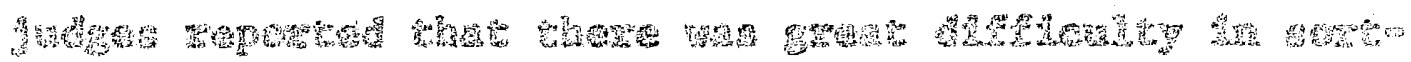
An 


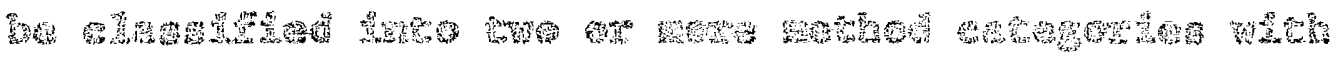

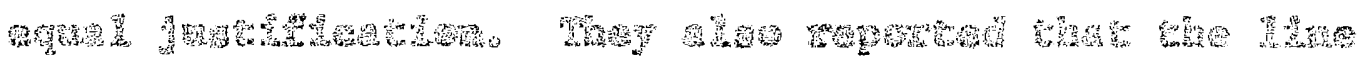

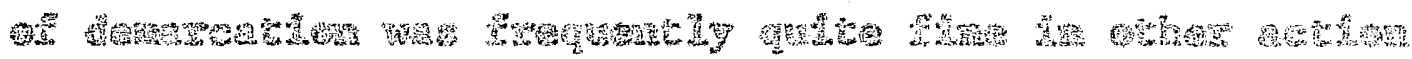

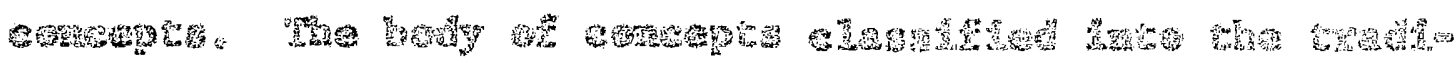

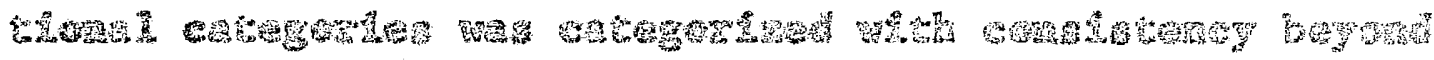

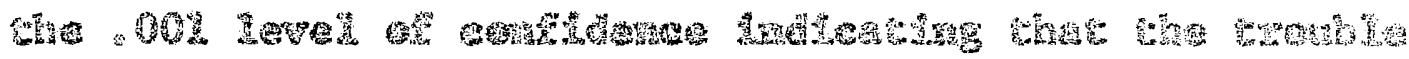

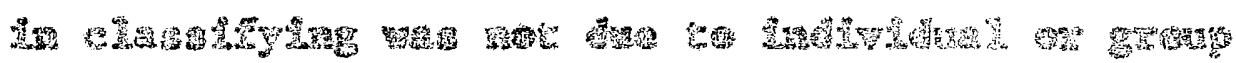

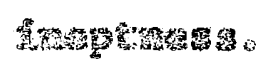

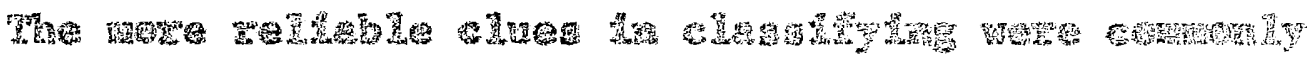

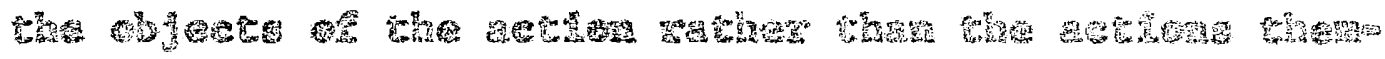

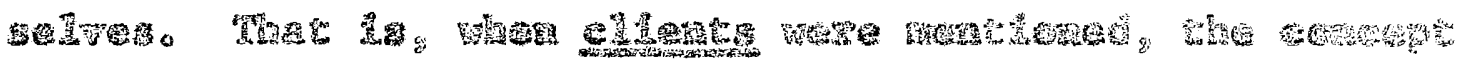

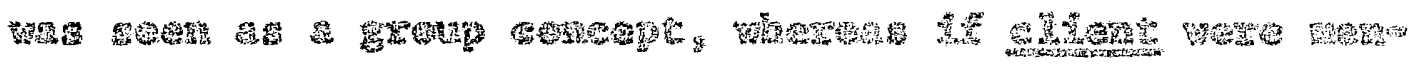

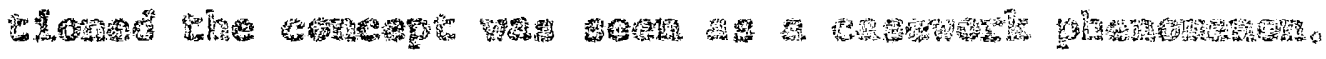
"rin

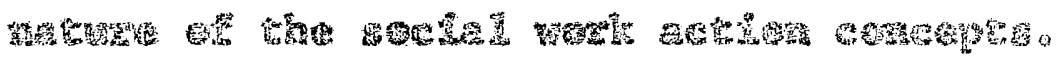

A

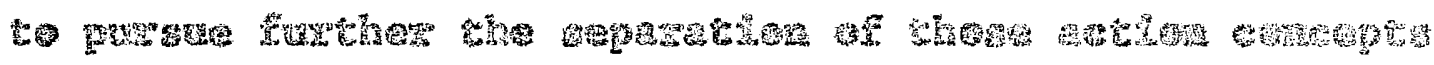

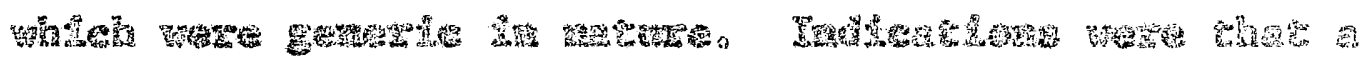

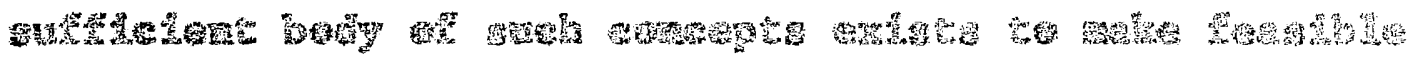

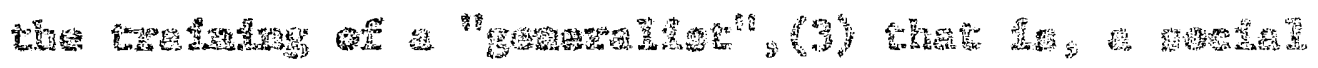

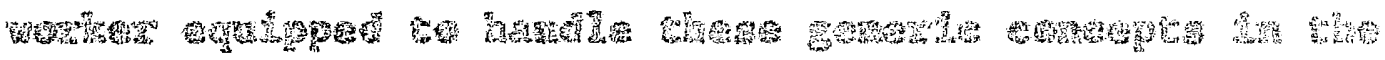

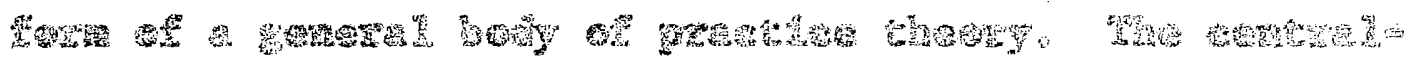

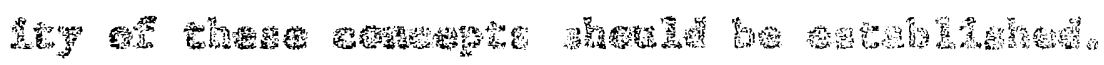

A

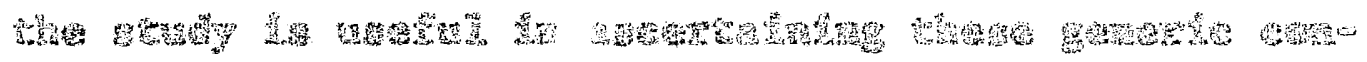

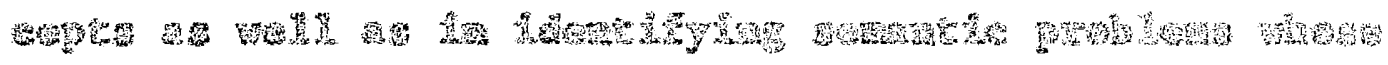

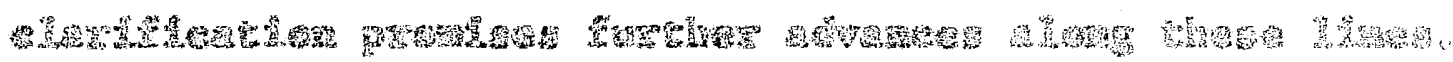




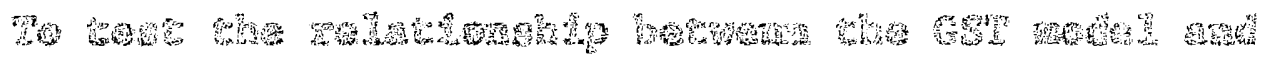

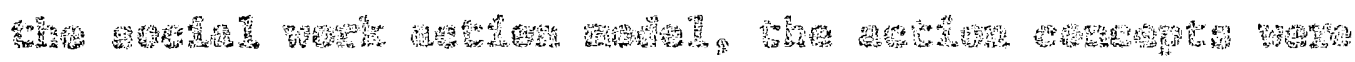

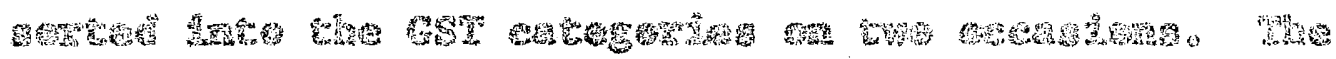

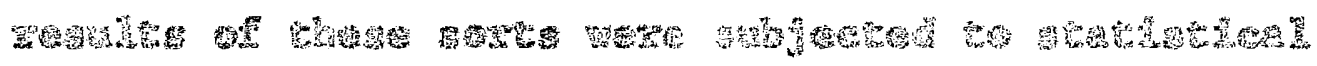

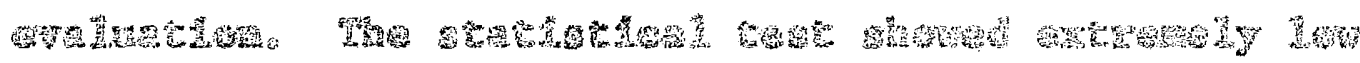

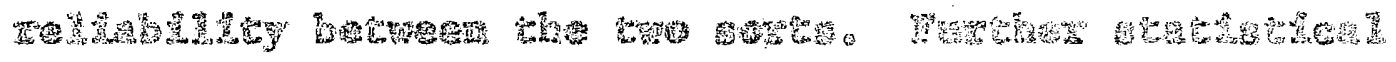

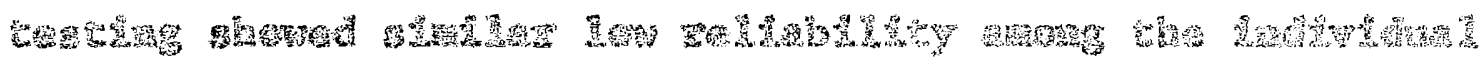
与

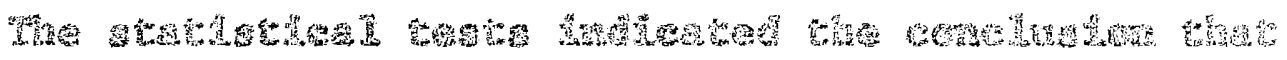

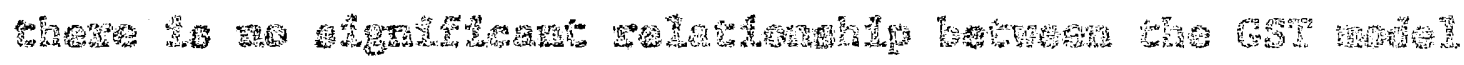

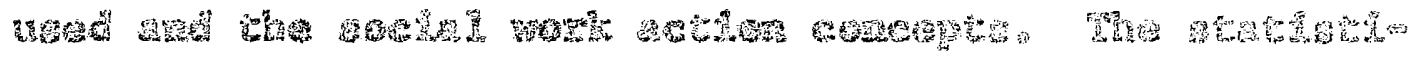

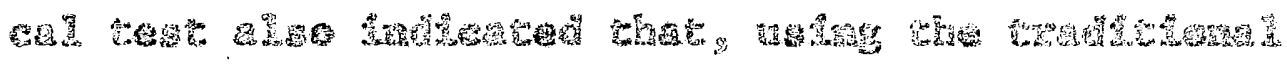

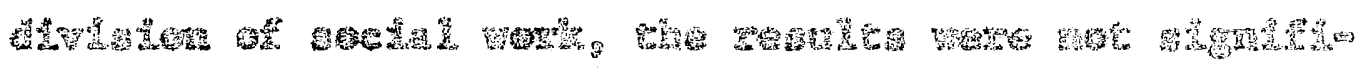

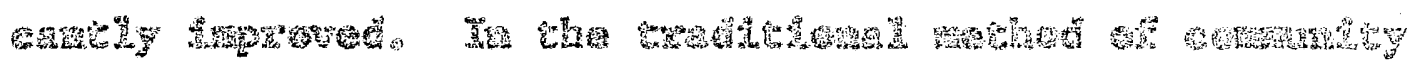

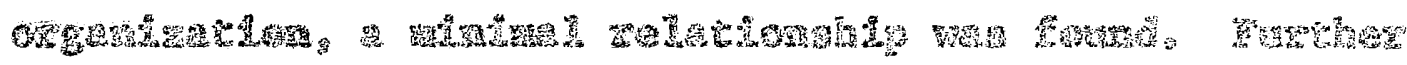

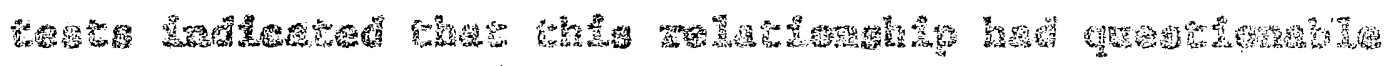

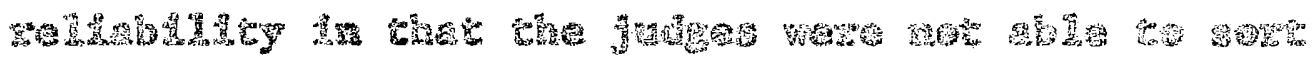

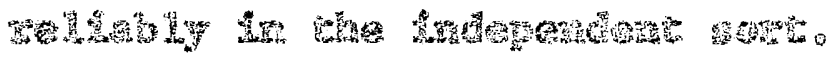

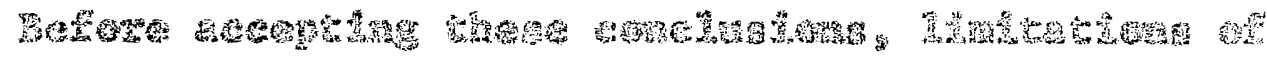

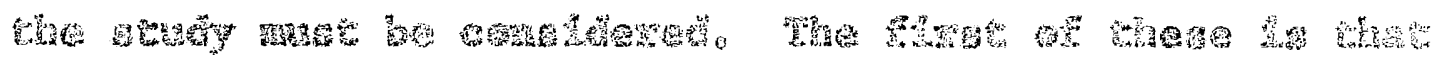

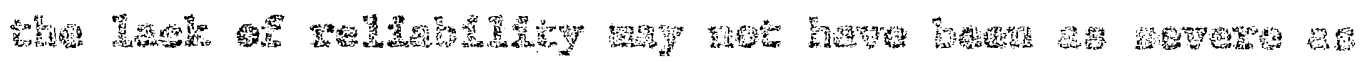

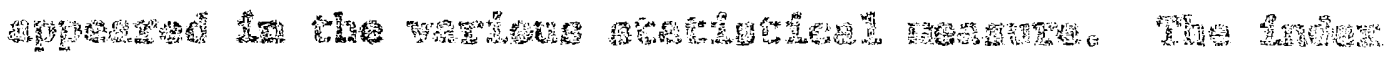

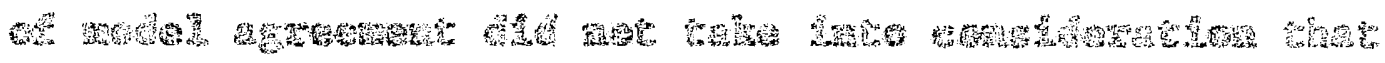

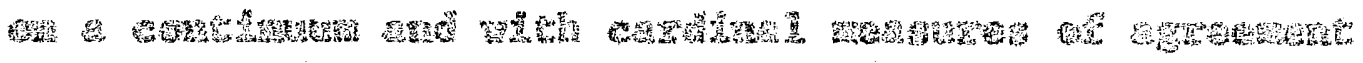

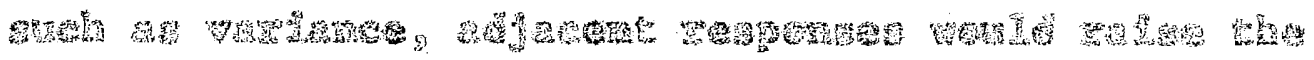




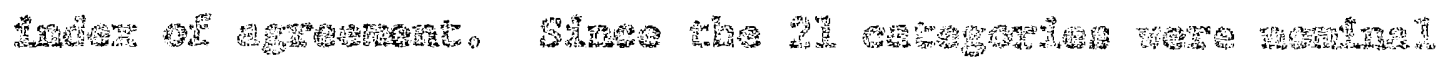

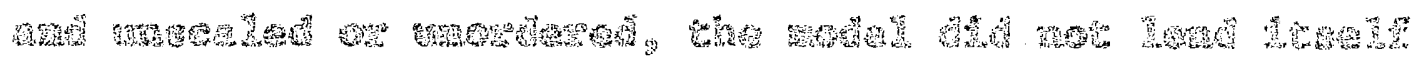

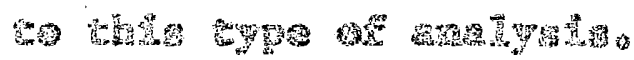

Tph

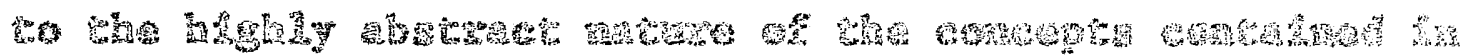

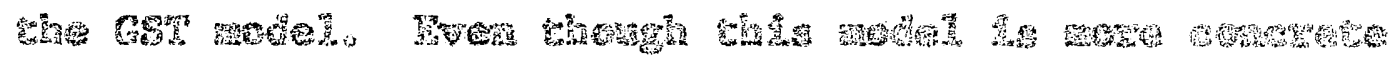

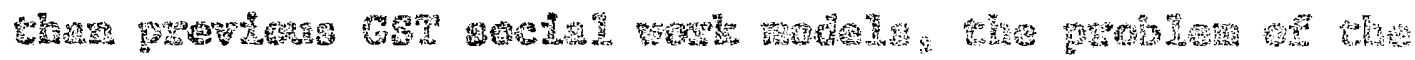

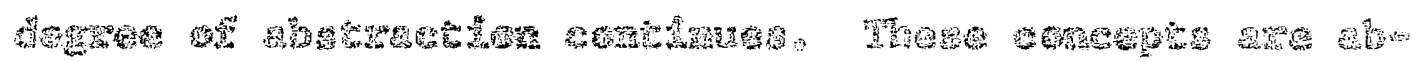

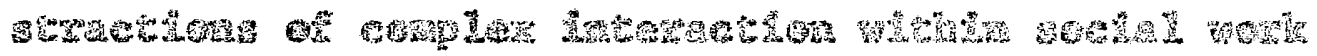

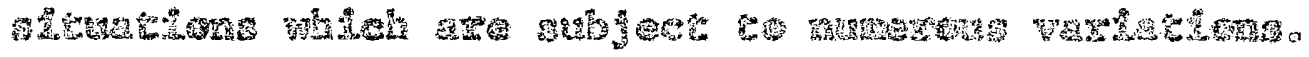

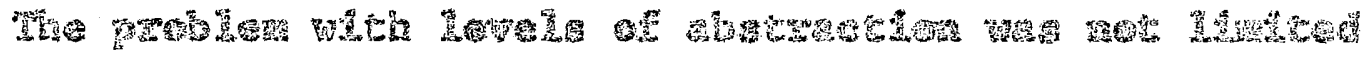

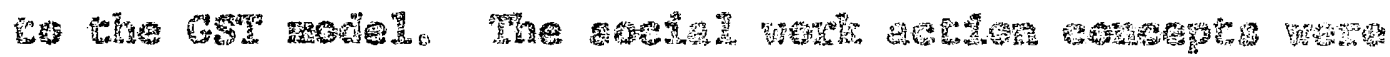

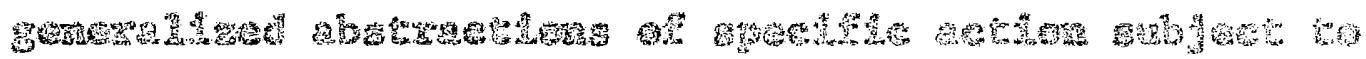

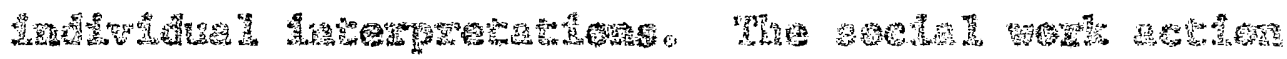

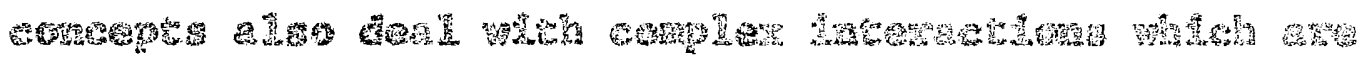
Bugly

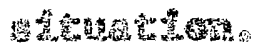

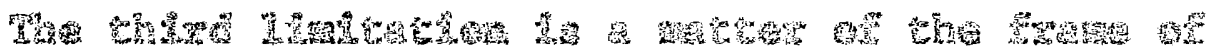

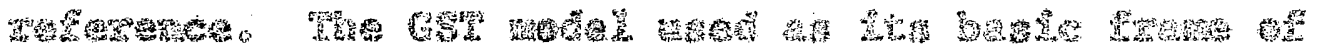

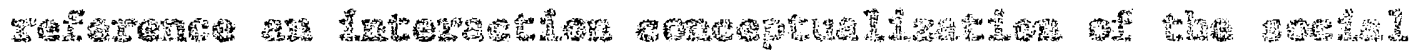

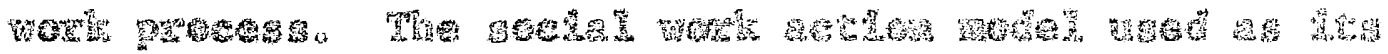

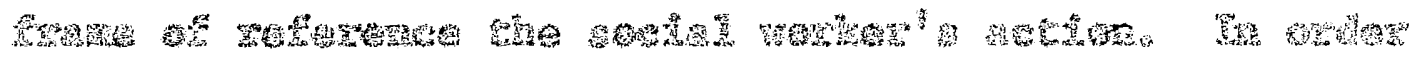

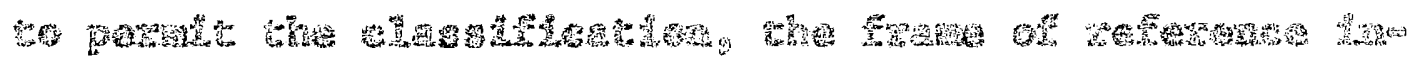

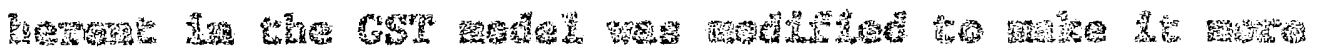

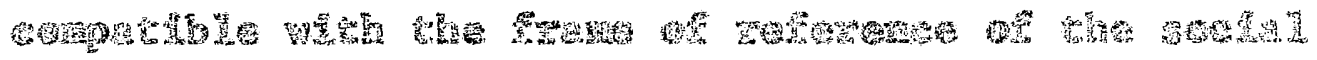




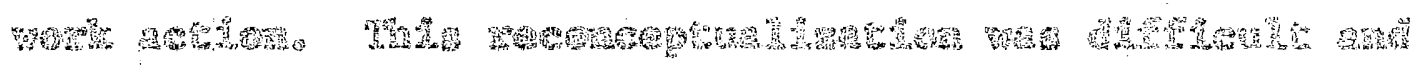

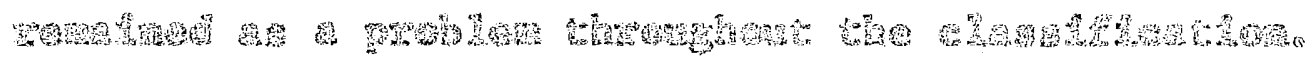

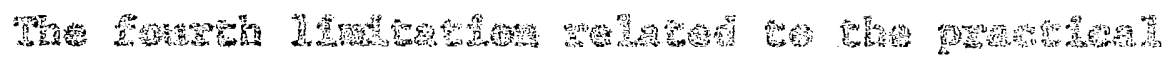

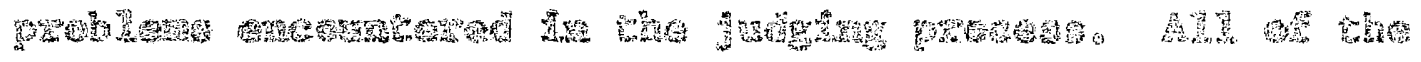

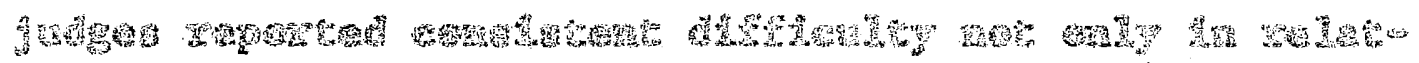

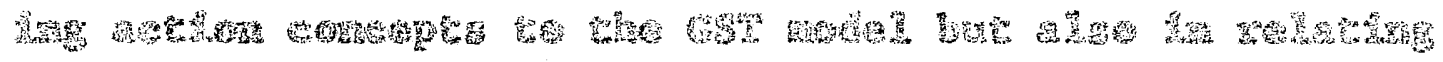

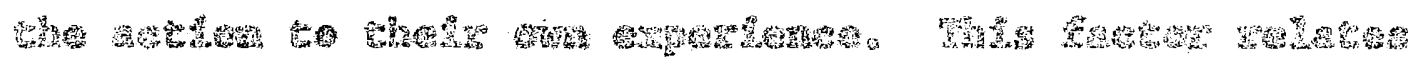

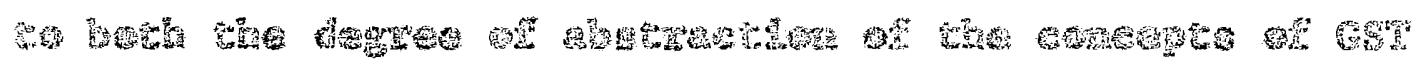

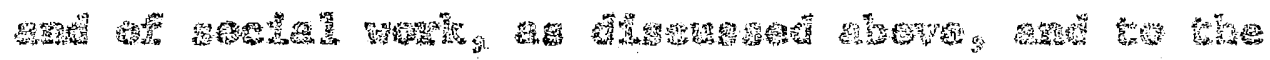

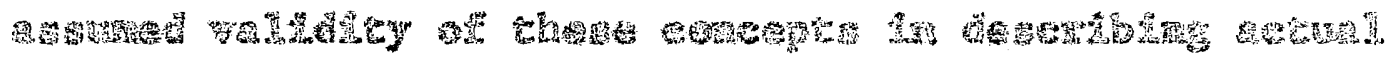

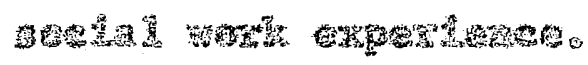

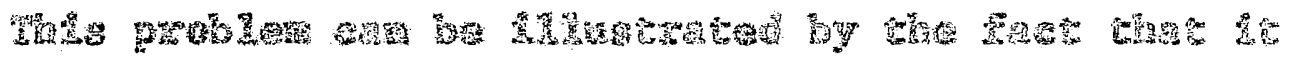

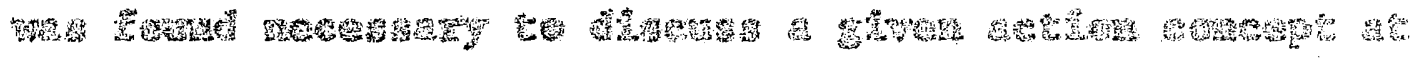

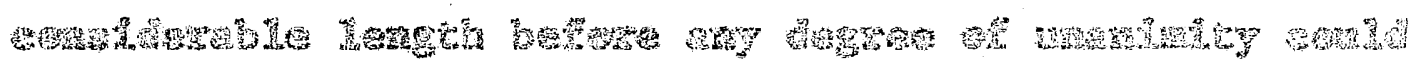

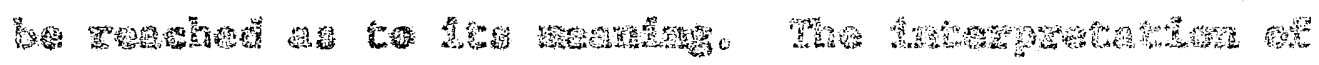

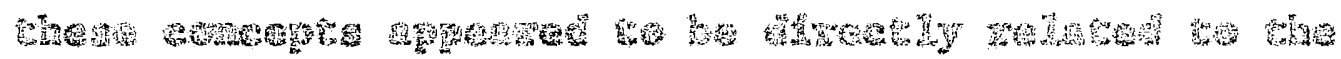

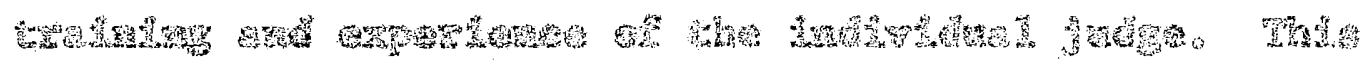
W

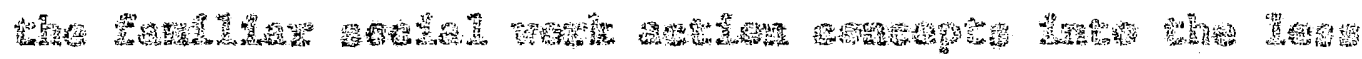

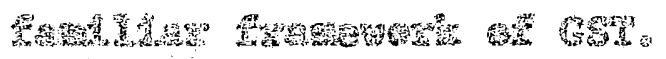

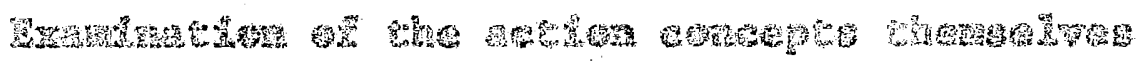

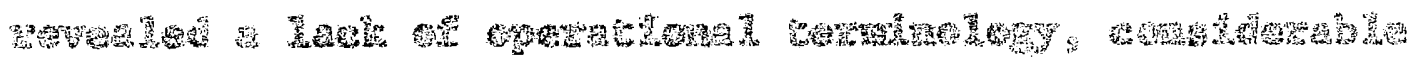

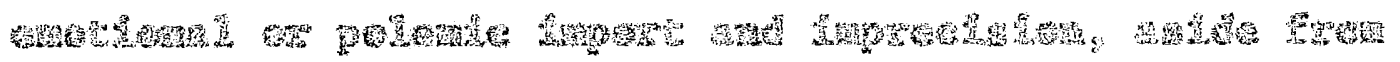

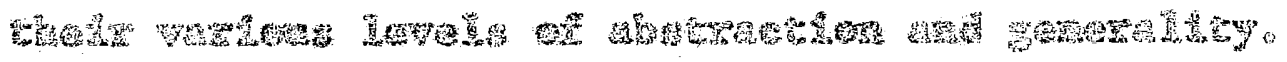

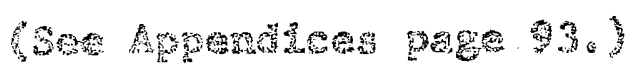


Tha

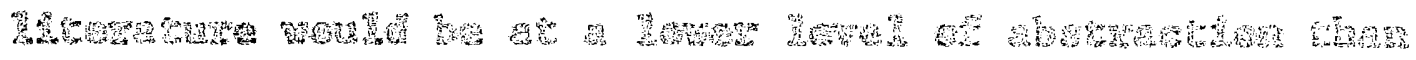

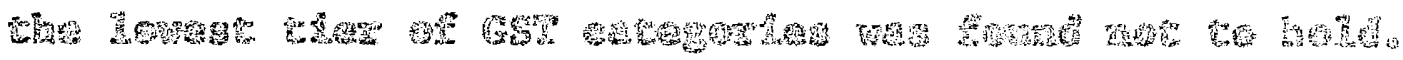

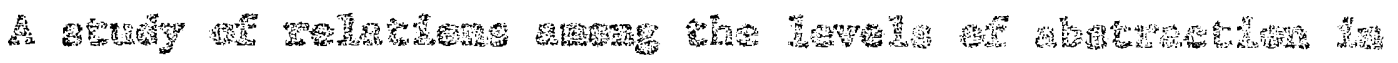

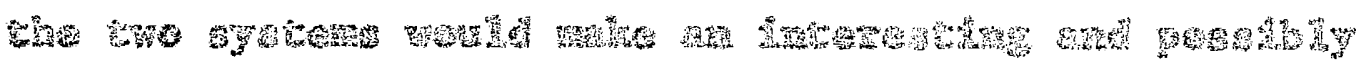

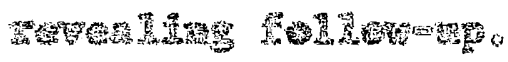

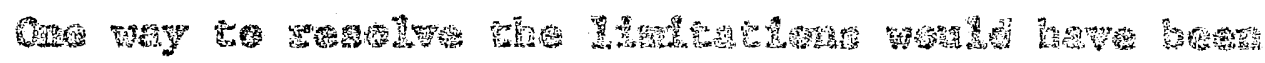

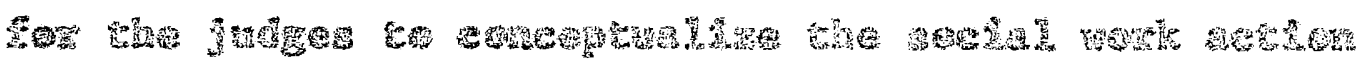

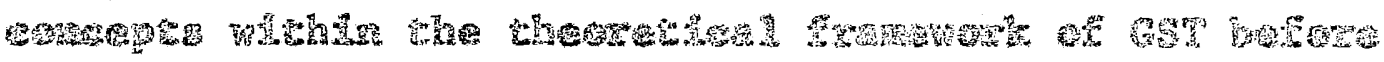

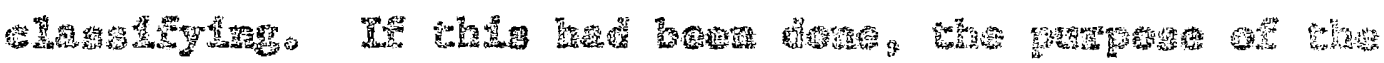

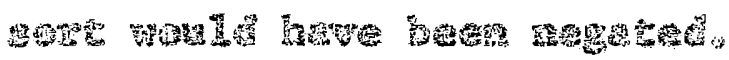

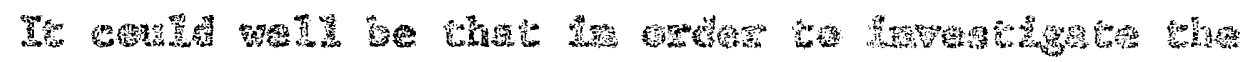

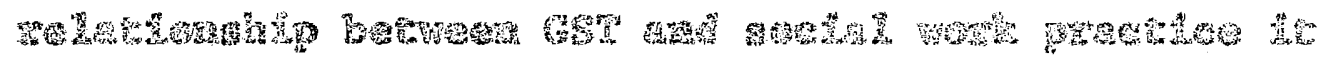

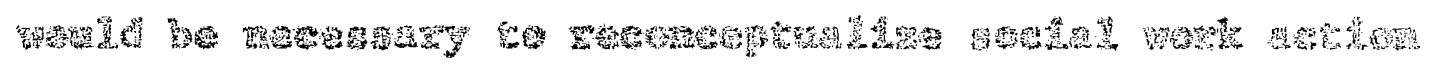

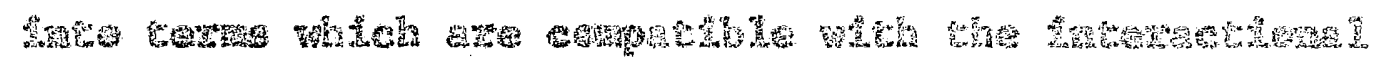

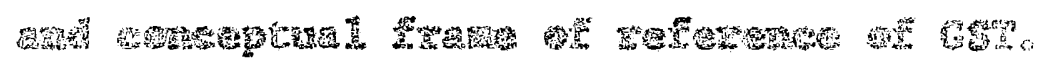

9月1

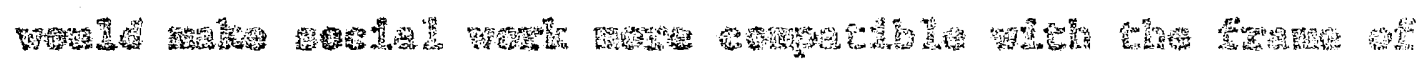

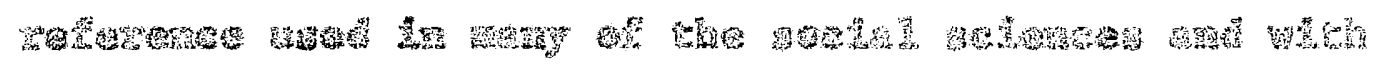

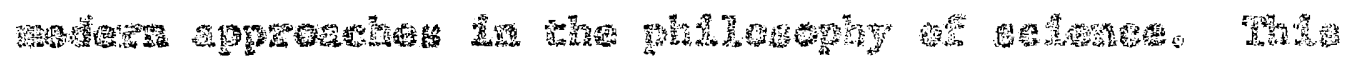

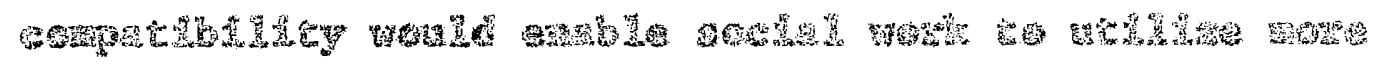

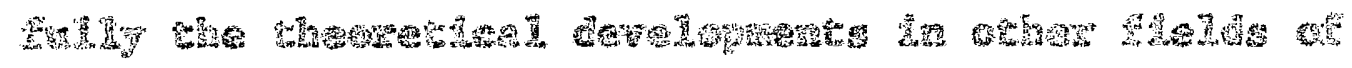

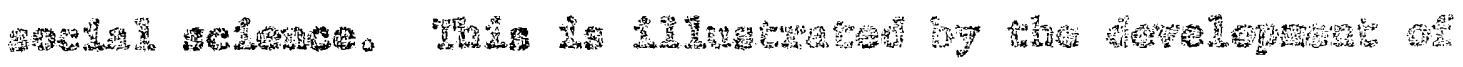

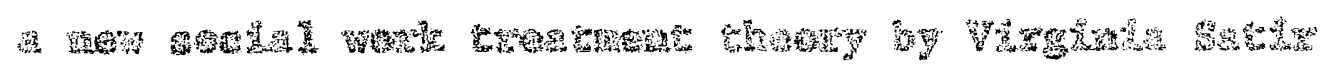

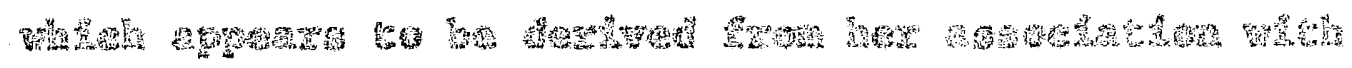

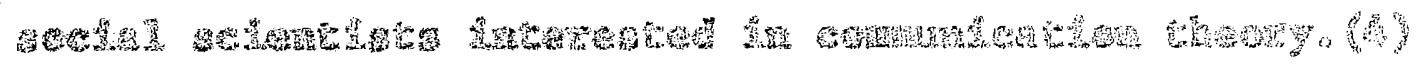




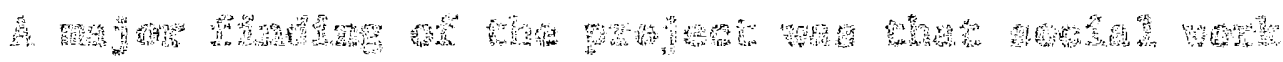

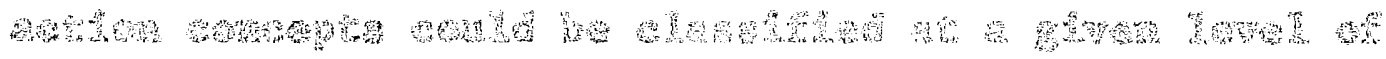

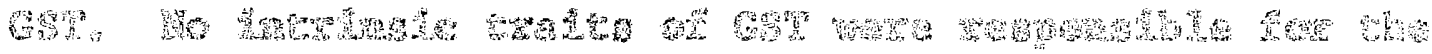

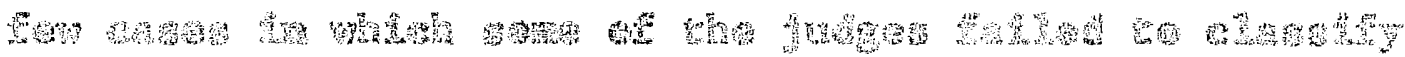
要裙

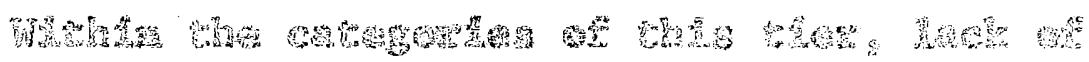

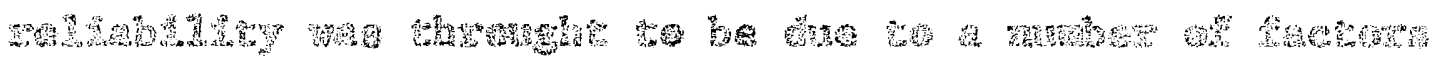

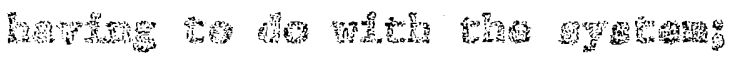

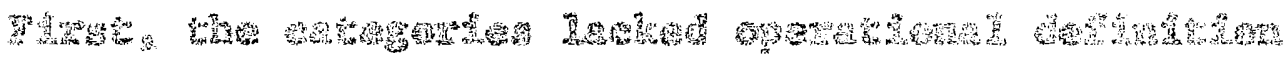

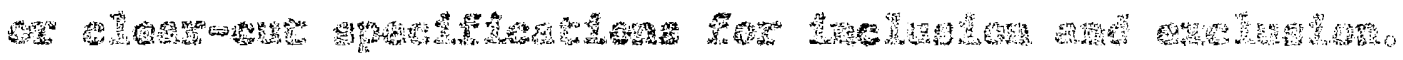
कow

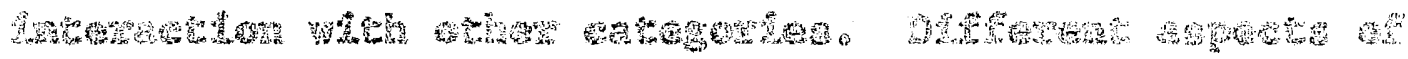

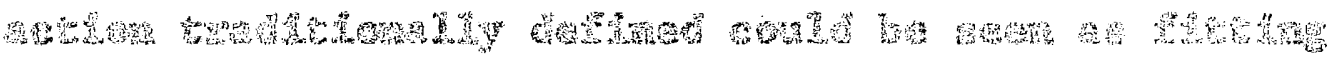

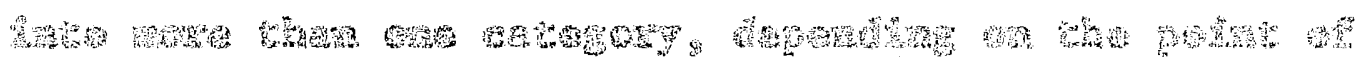

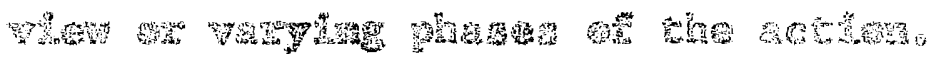

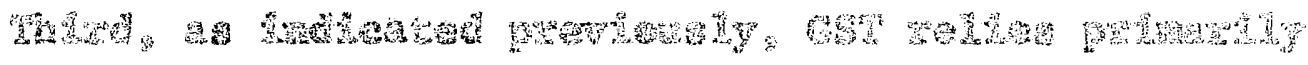

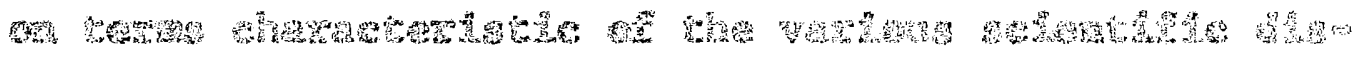

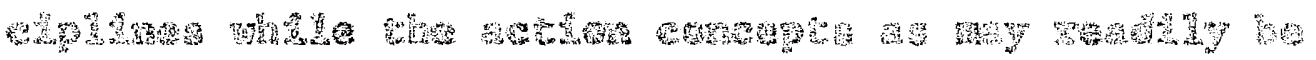

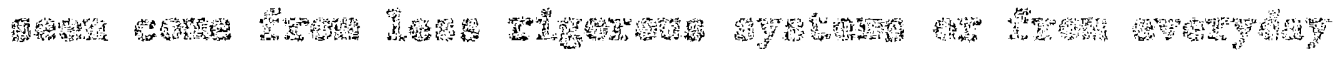

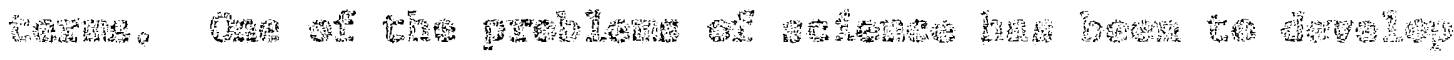

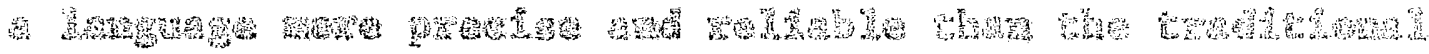

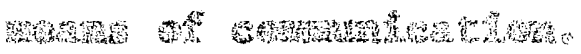

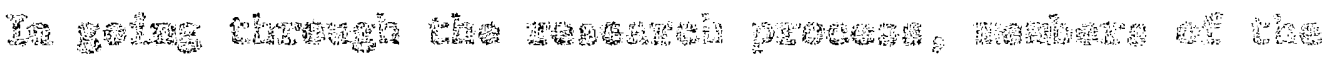
5.

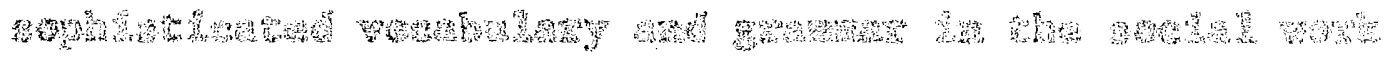
s. 
What

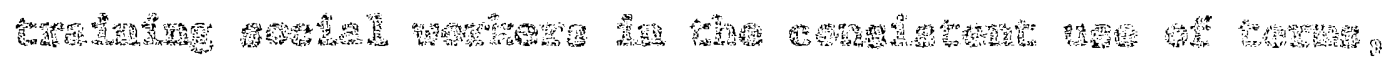

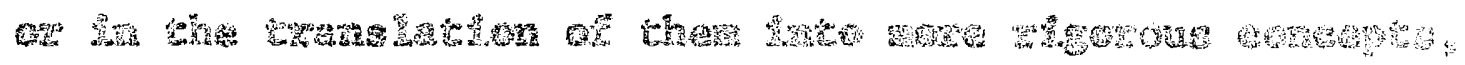

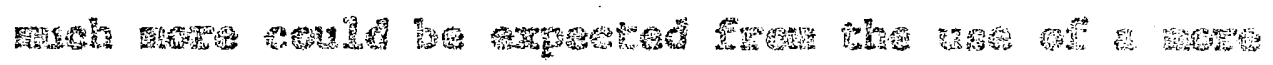

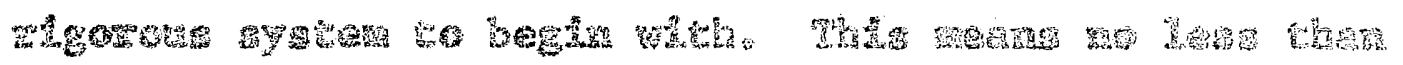

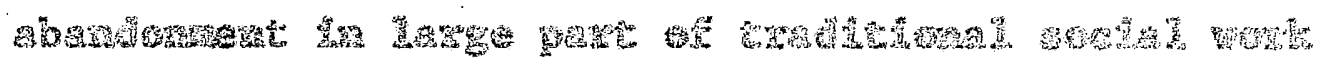

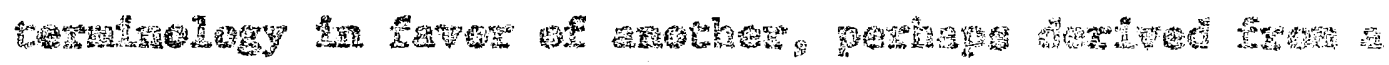

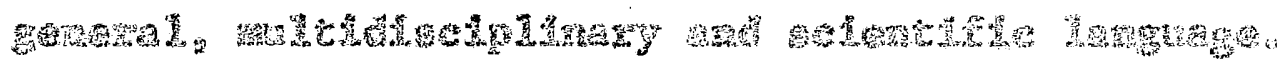

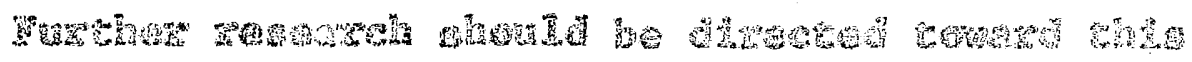

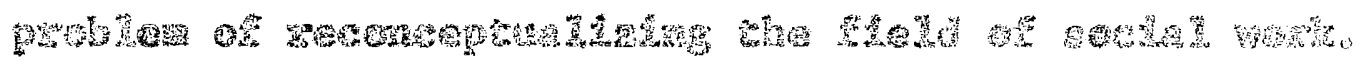

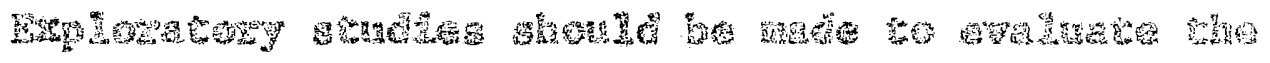

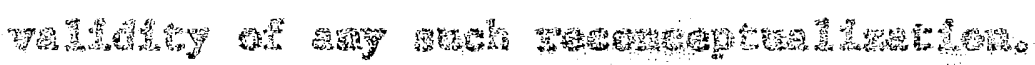

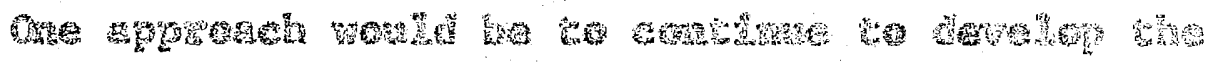

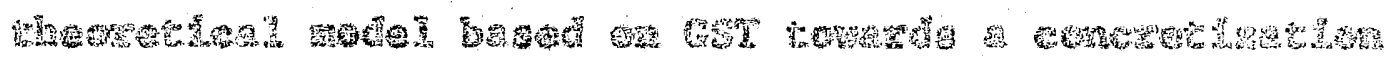

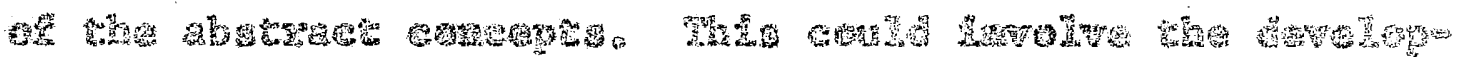

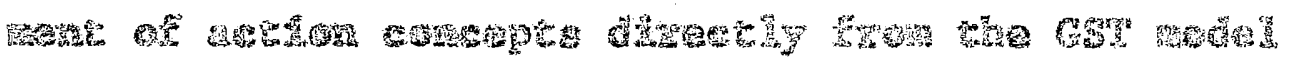

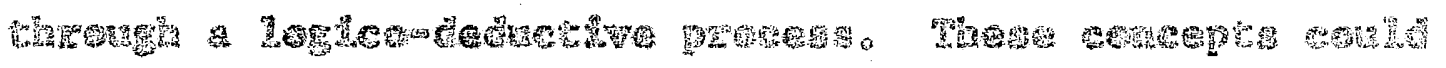
1ำ

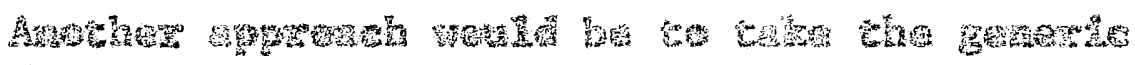

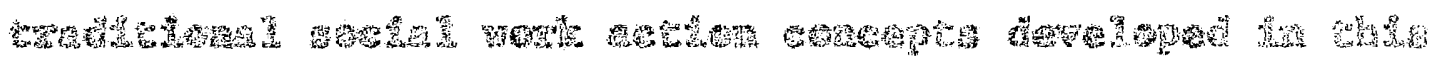

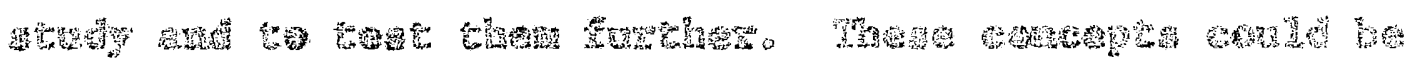

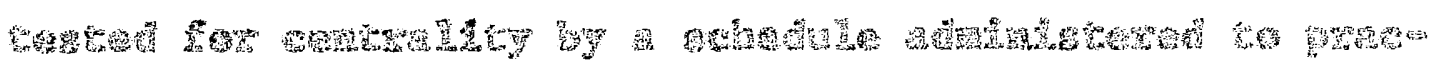

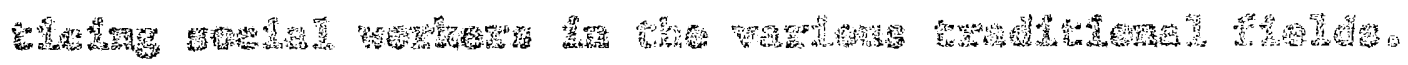

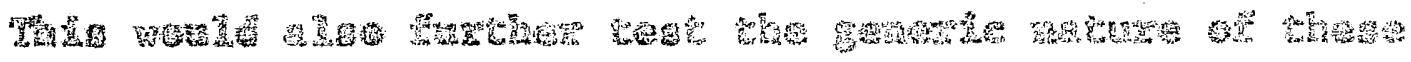
a

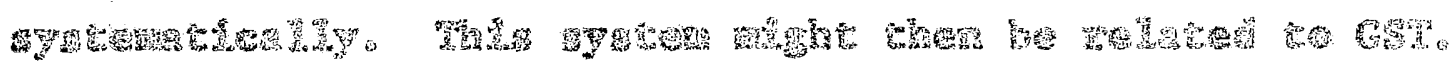




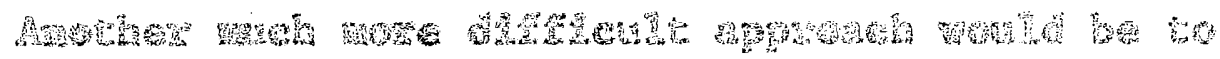

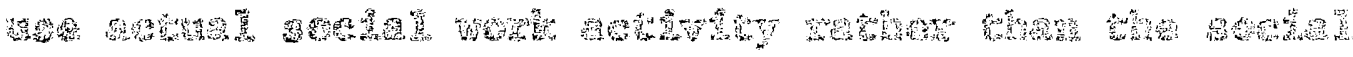

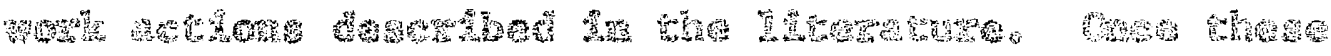

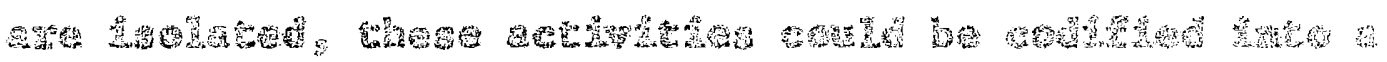
Fry

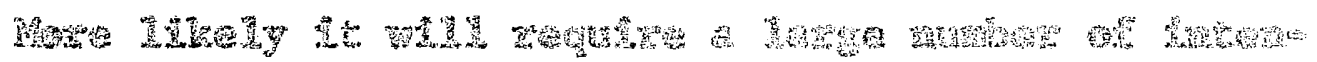

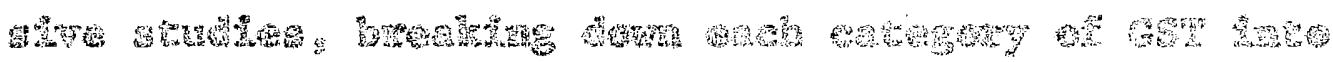
路W

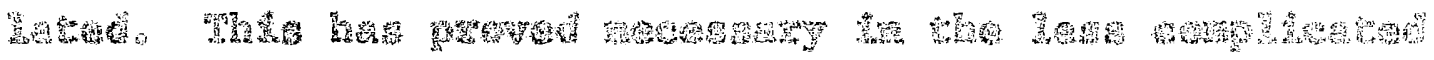

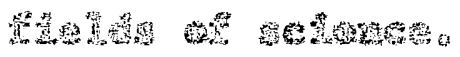

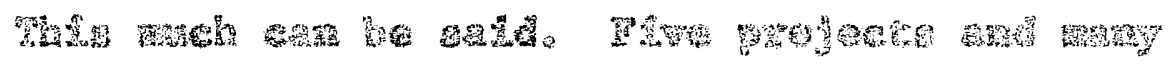

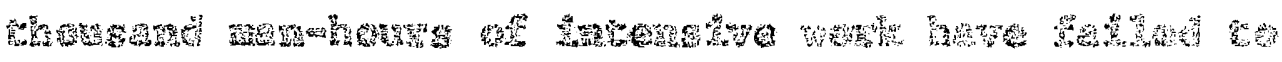

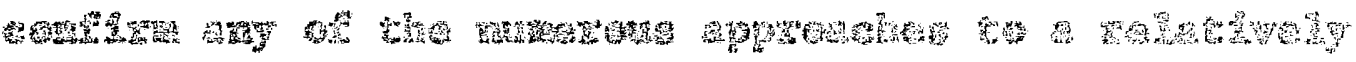

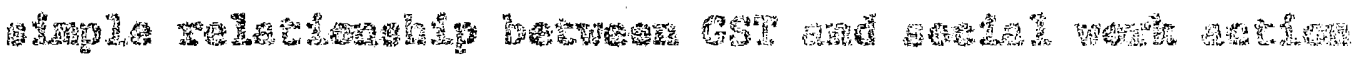

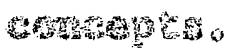




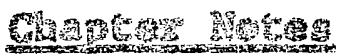

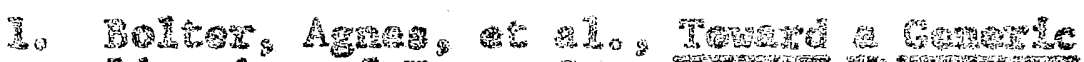

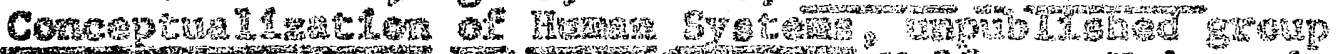

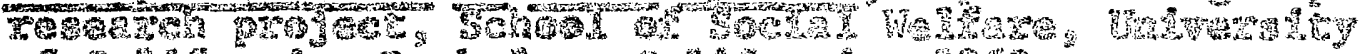

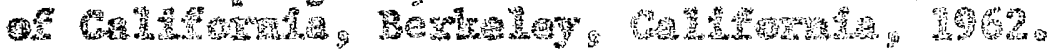

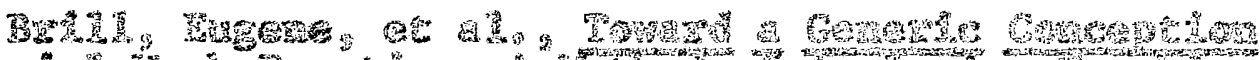
HE Eq

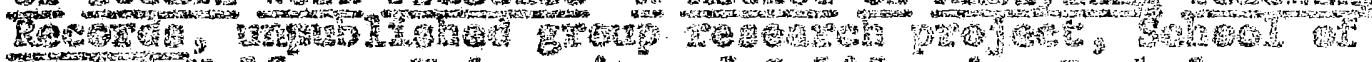

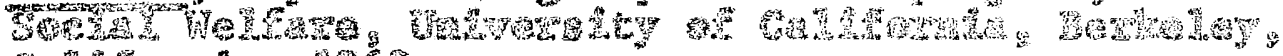

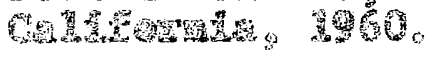

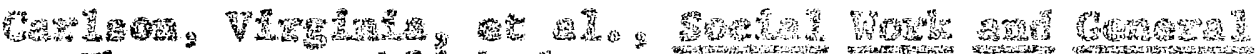

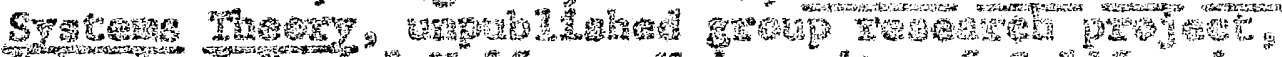

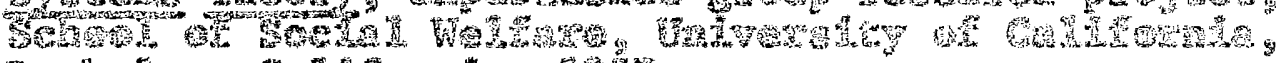

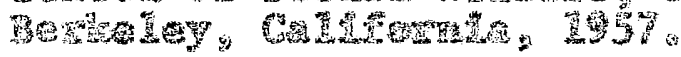

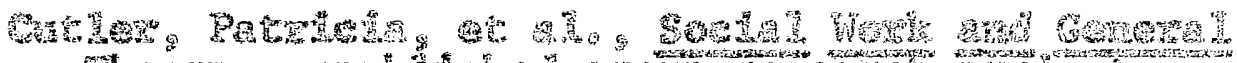

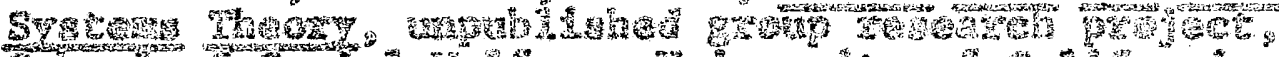

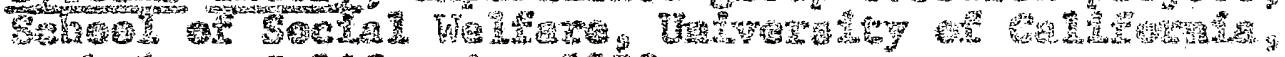

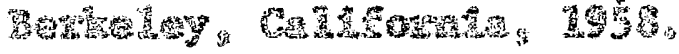

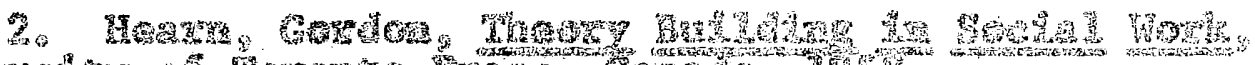

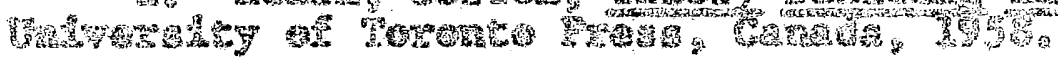

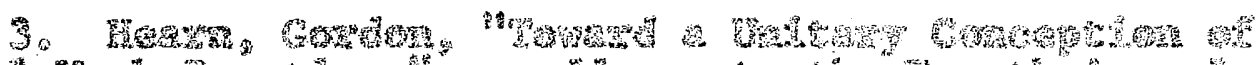

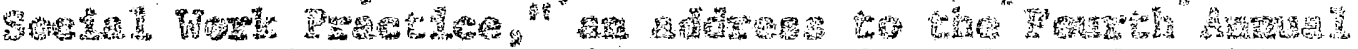

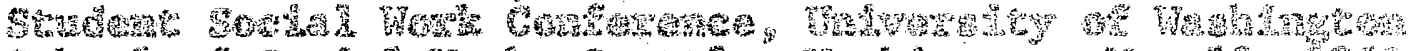

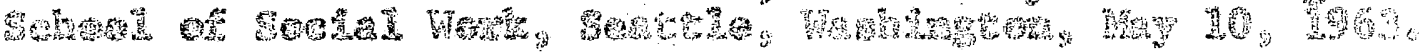

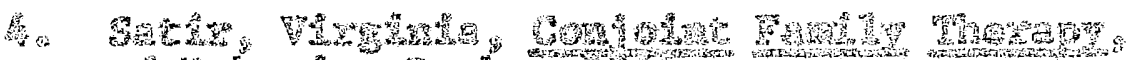

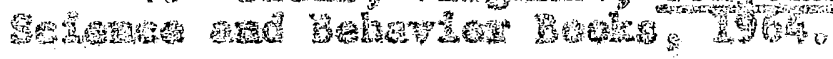




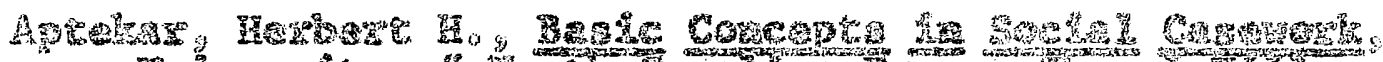

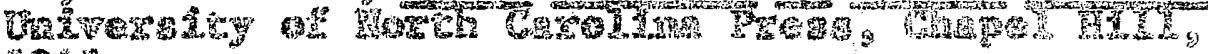

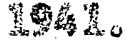

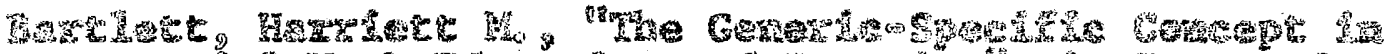

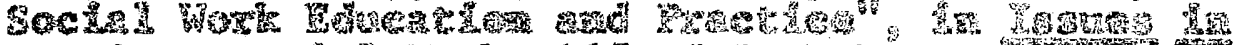
Araex d.

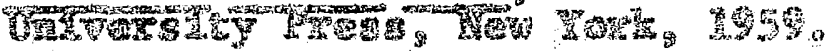

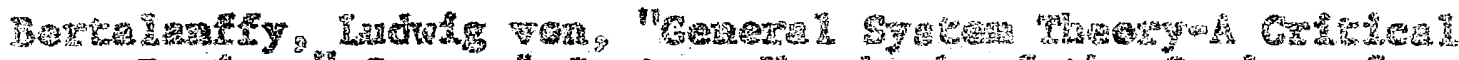

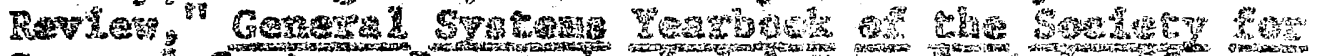

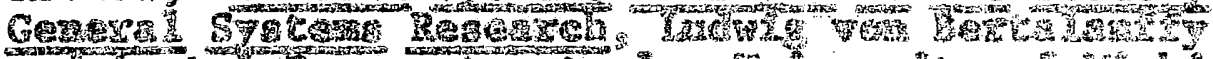

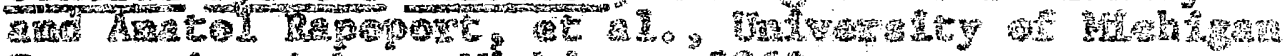

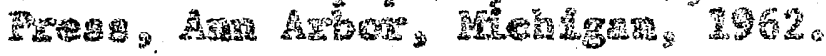

Fa

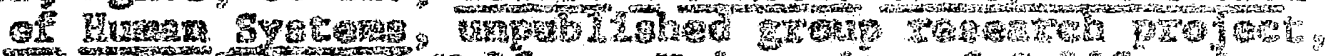

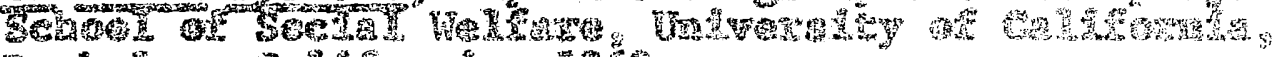

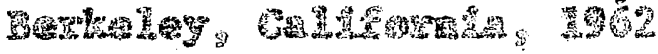

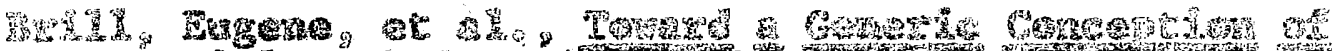

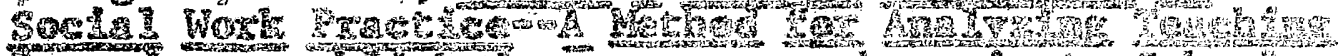

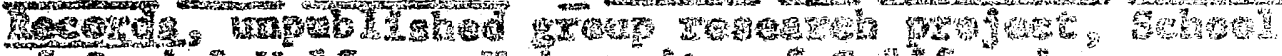

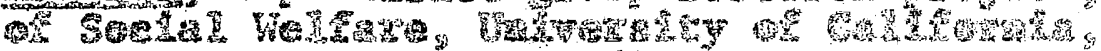

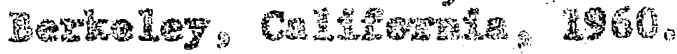

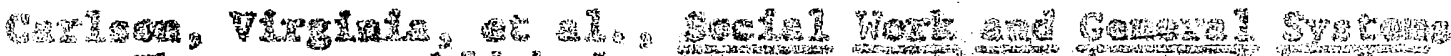

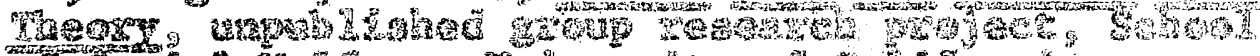

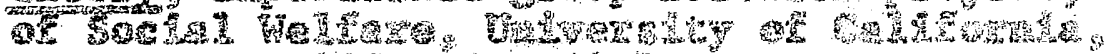

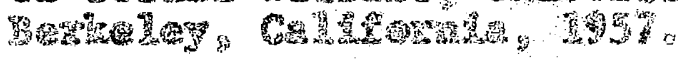

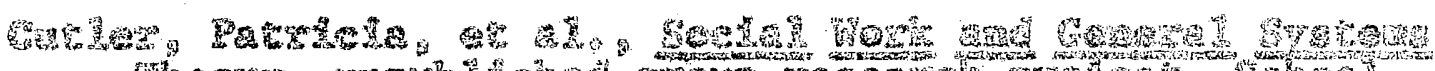

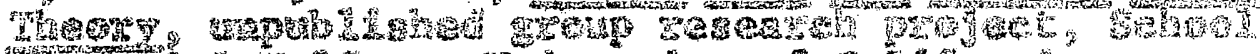

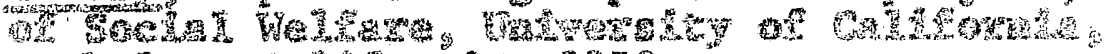

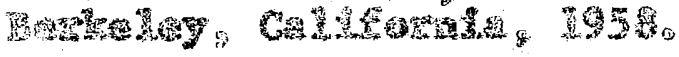

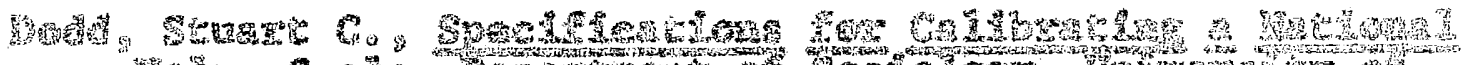

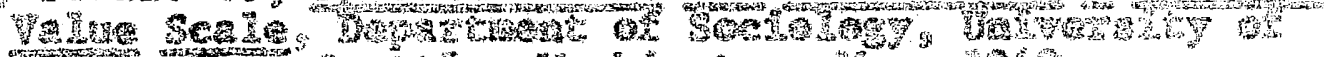

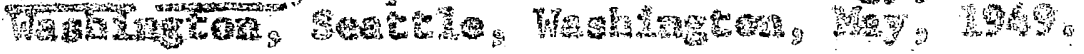




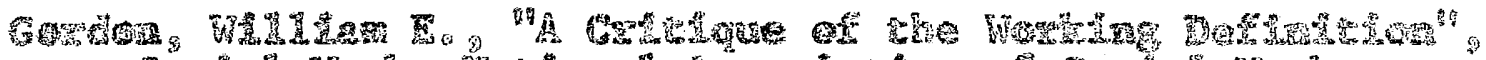

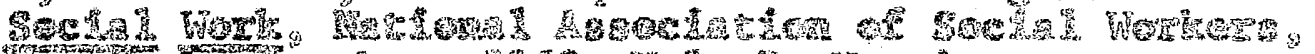
M

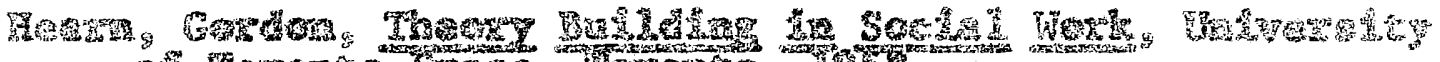
O: Tox

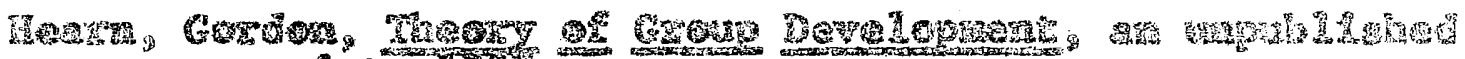

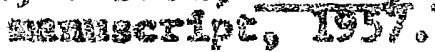

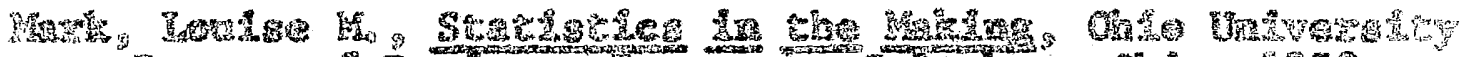

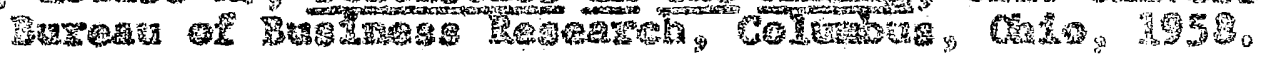

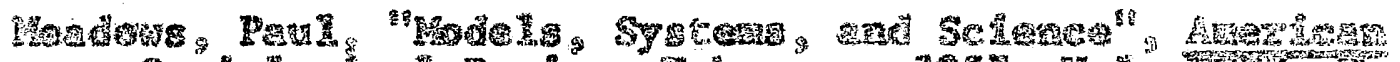

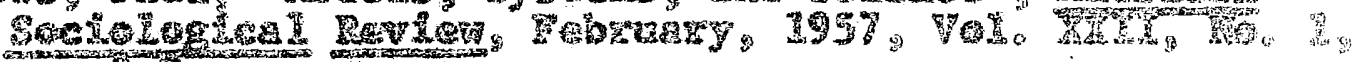

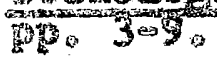

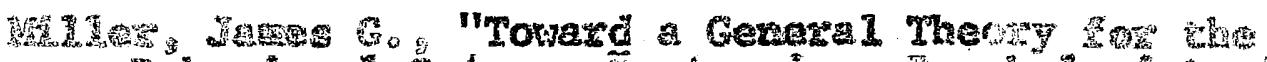

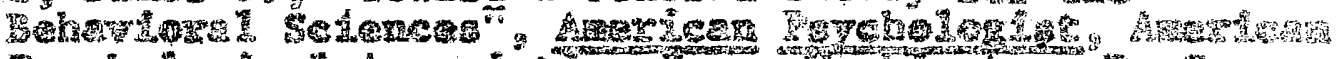

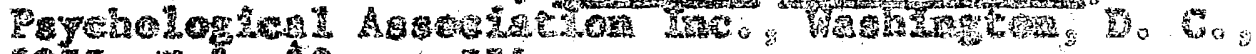

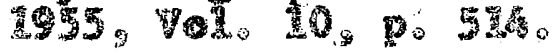

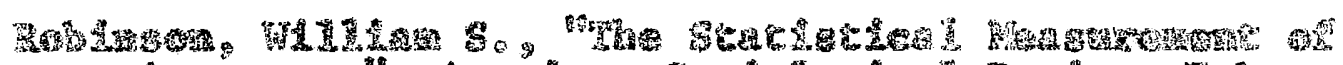

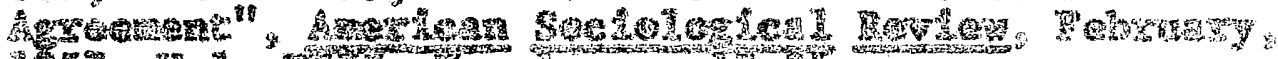

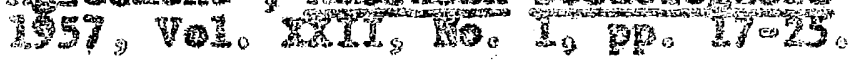

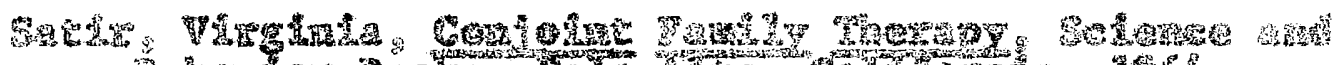

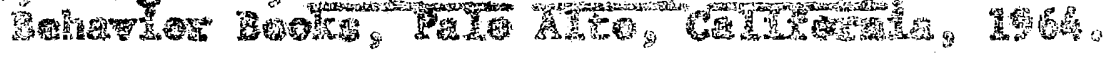

3.3.

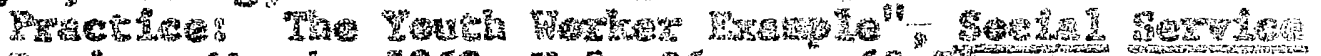
Shes:

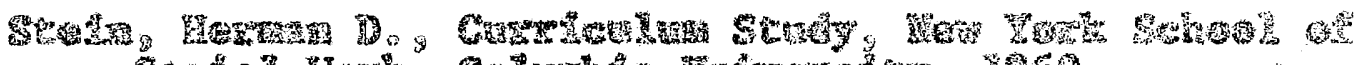
管

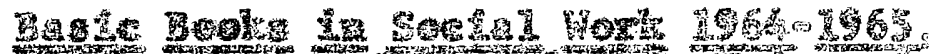

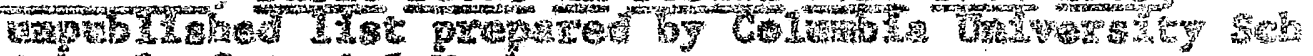

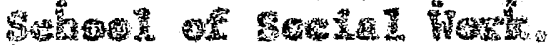

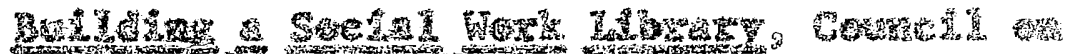

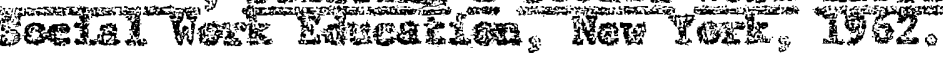


Fis

A. 
A

OWTE. FG G

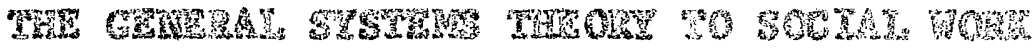

等

等 By

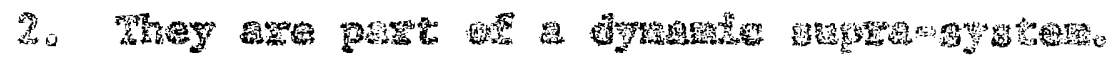

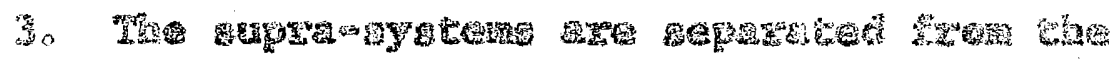

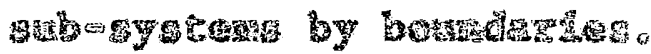

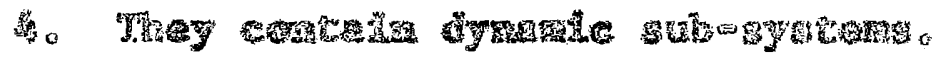

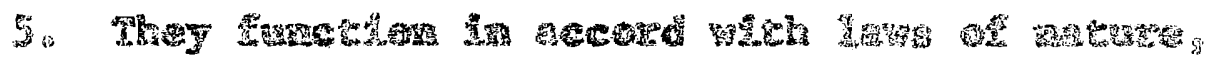

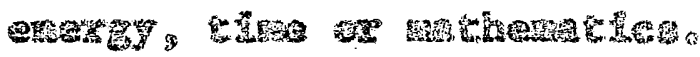

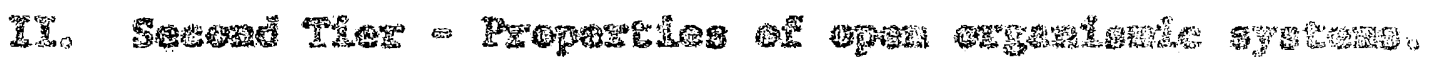

等。 FIn

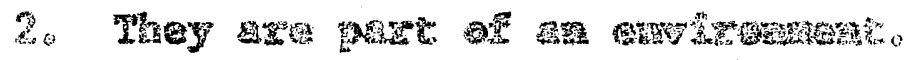

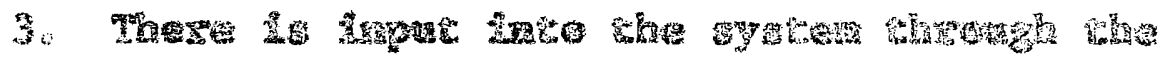

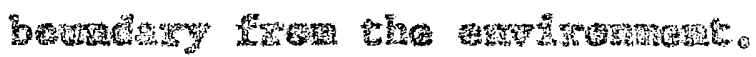

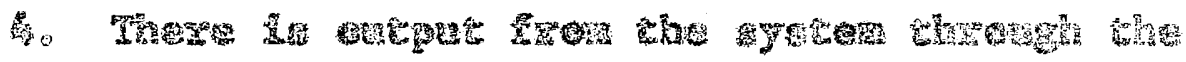

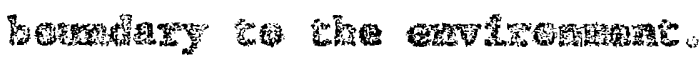

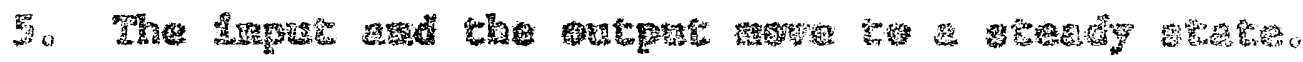

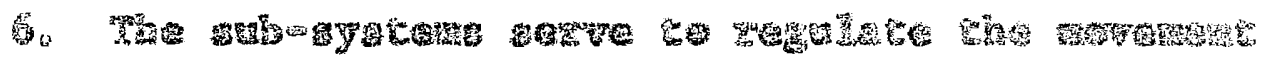
s.

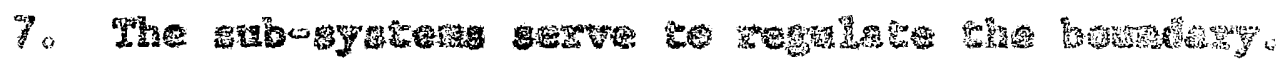

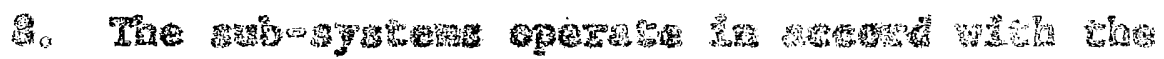

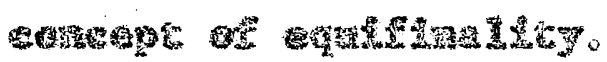




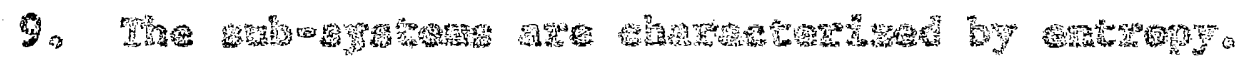

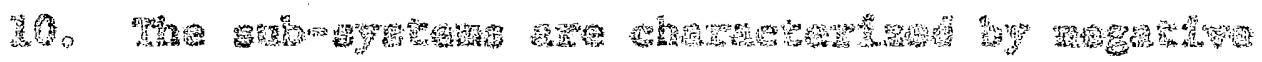

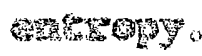

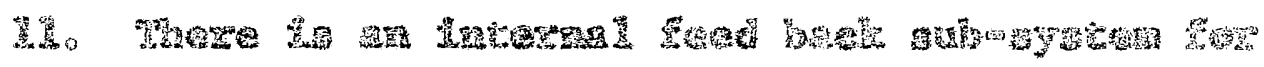

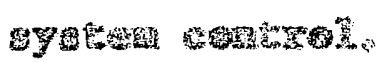

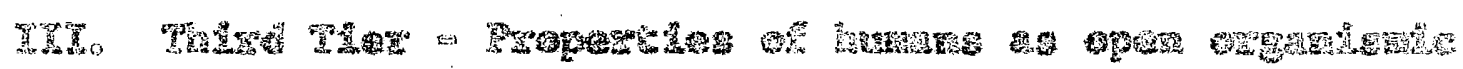

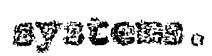

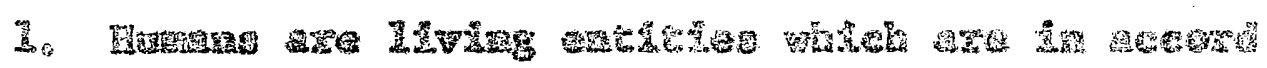

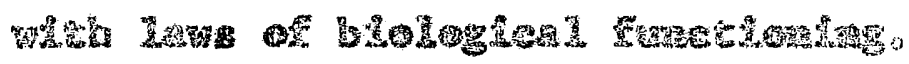

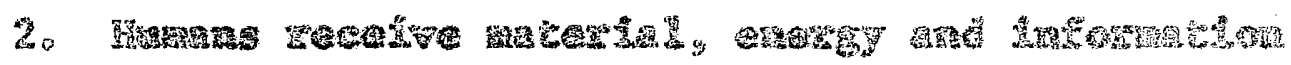

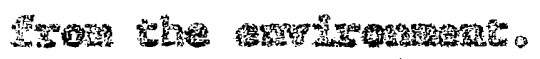

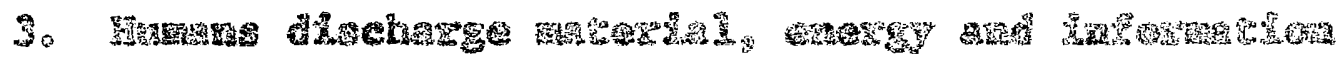

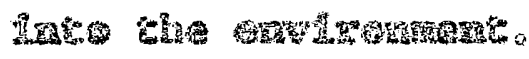

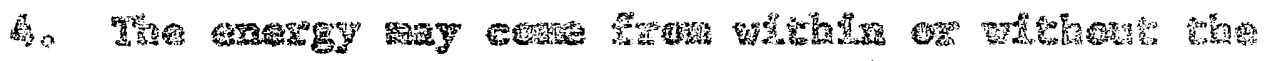

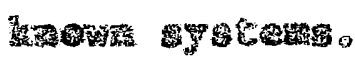

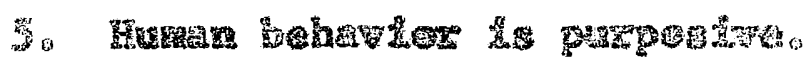

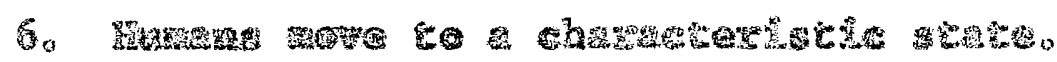

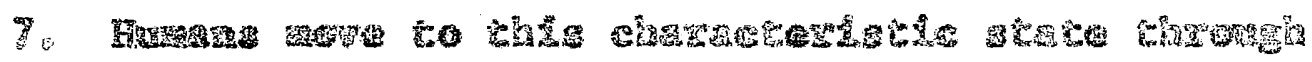

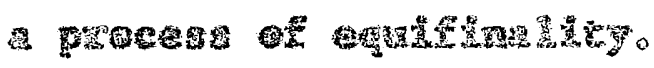

8. M

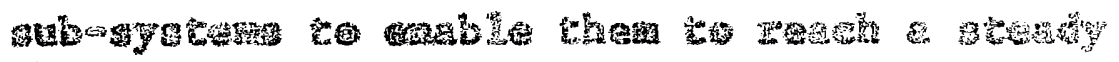
afsece

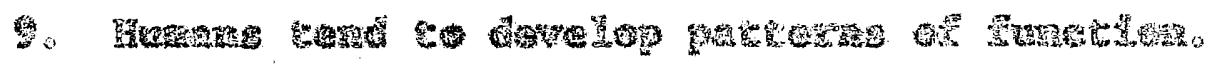

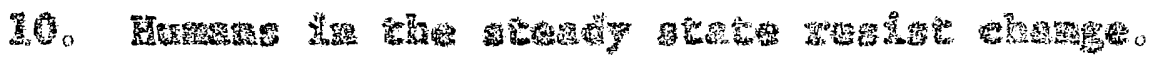

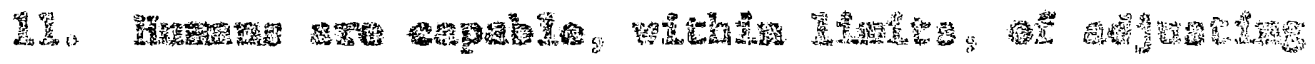

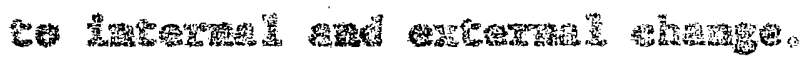




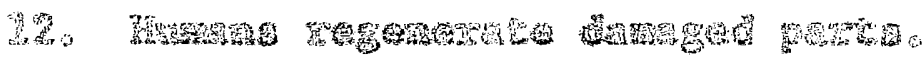

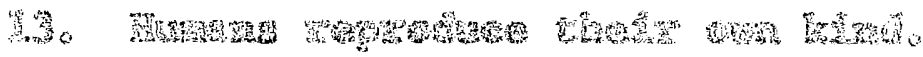

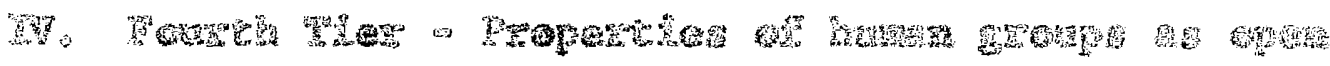
as

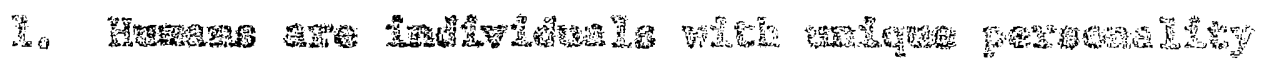

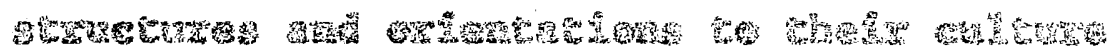

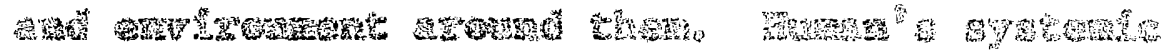

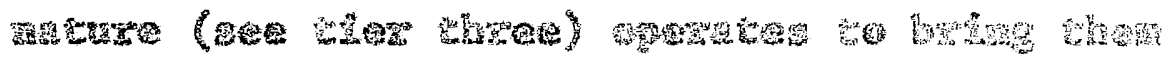

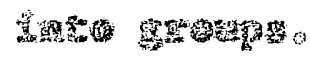

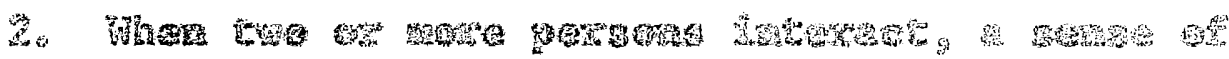

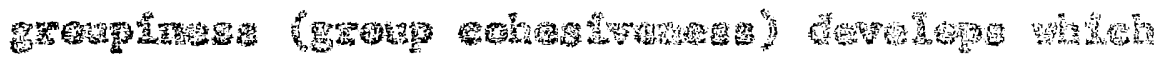

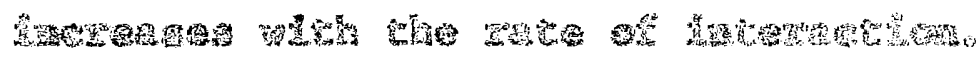

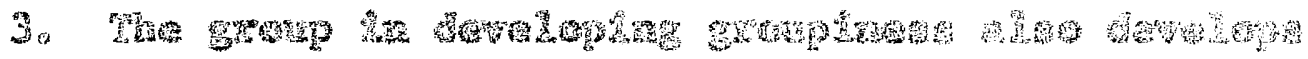

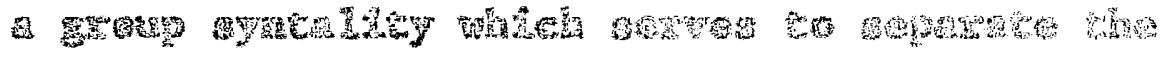

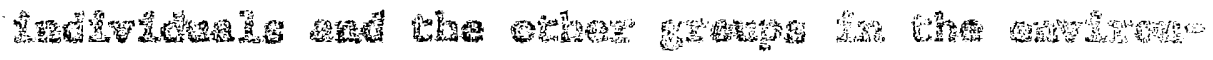

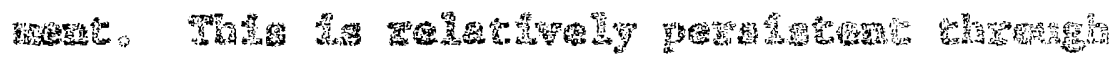

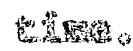

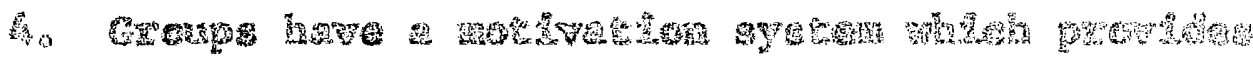

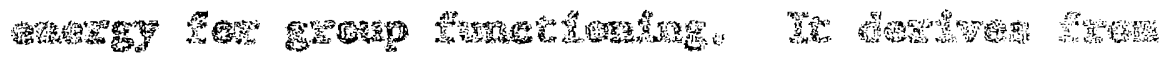

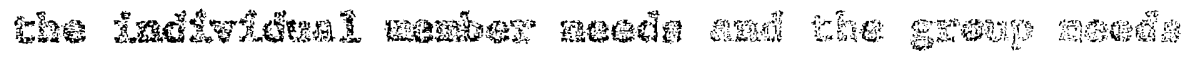

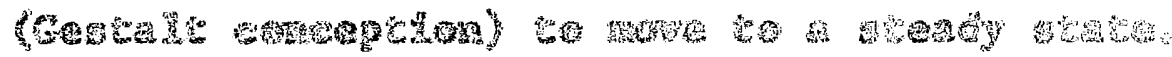

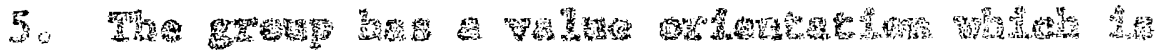

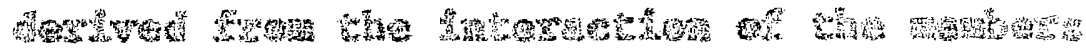

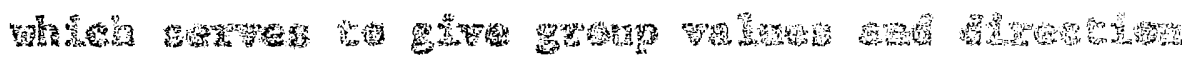

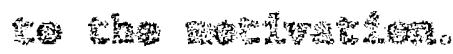




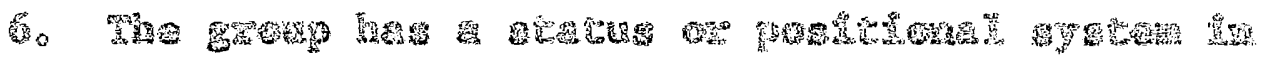

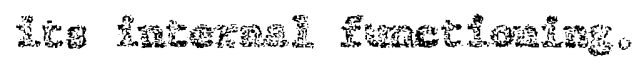

7. The grager

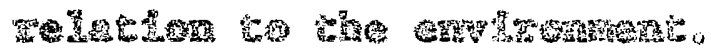

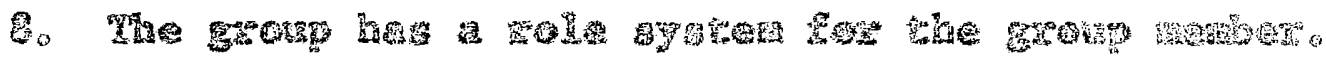

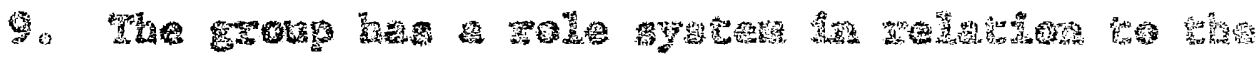

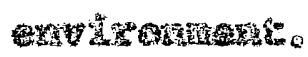

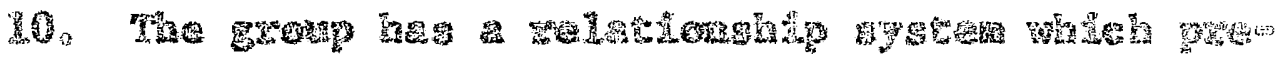

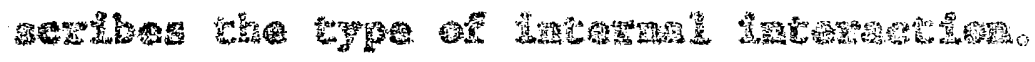

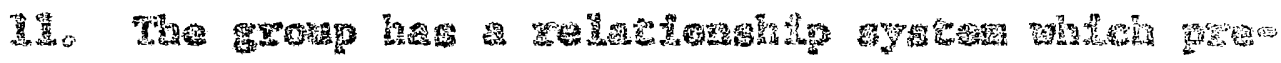

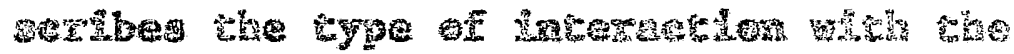

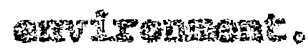

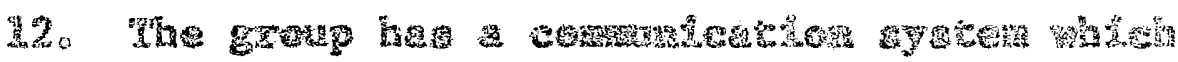

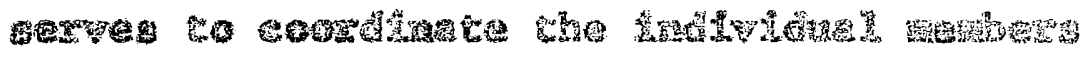

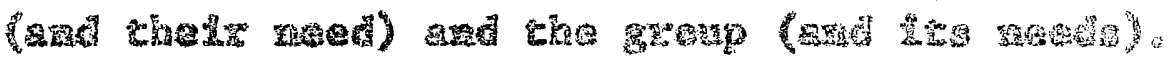
IC di

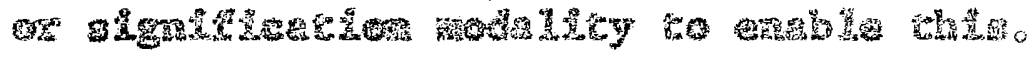

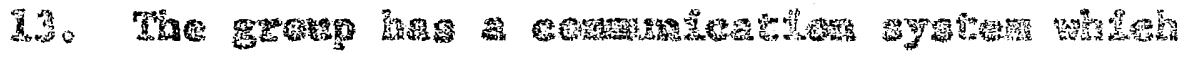
aerves co cowd

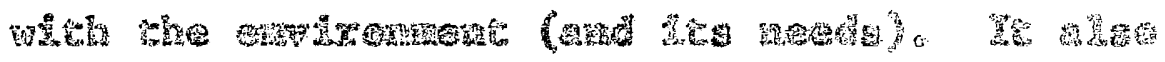

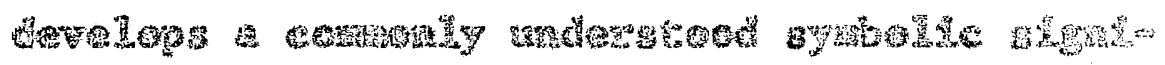

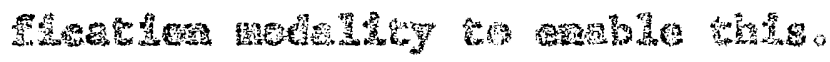

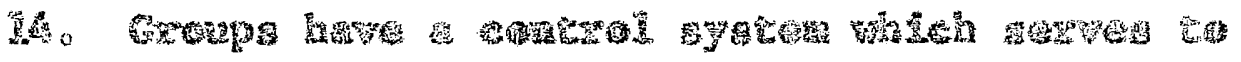
coved

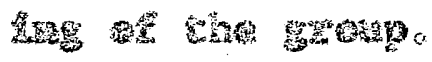




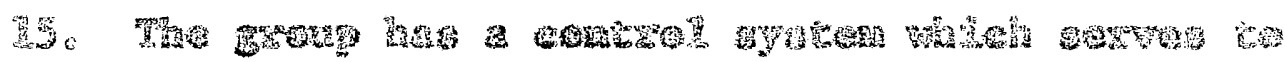

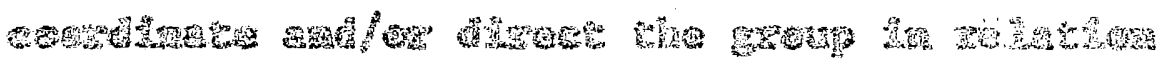

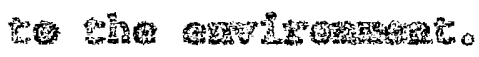

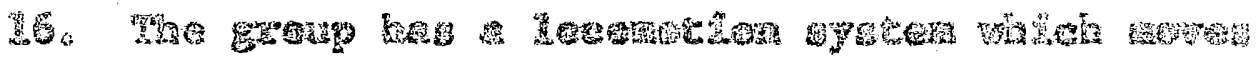

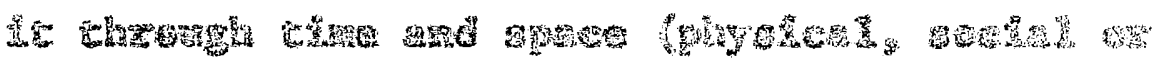

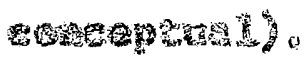

4y

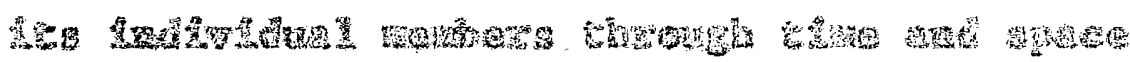

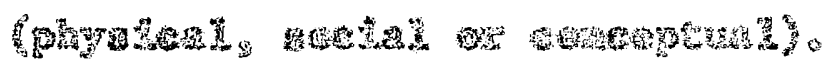

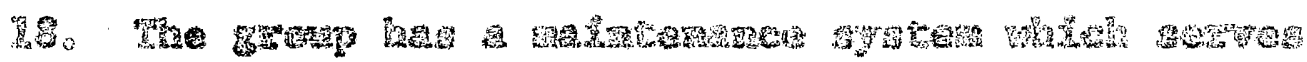

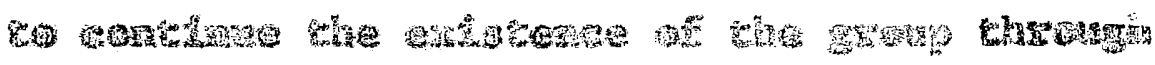
Freveration

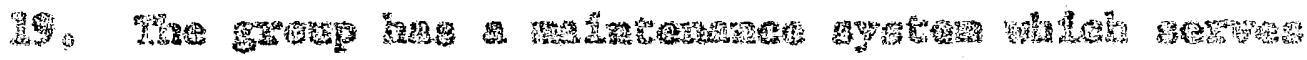

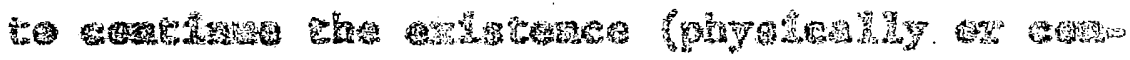

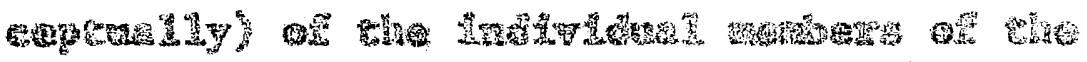

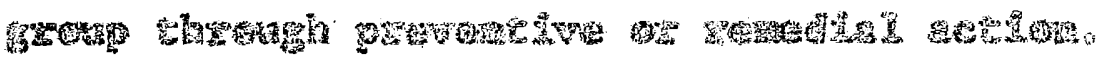

20. The

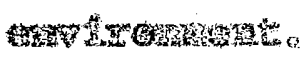

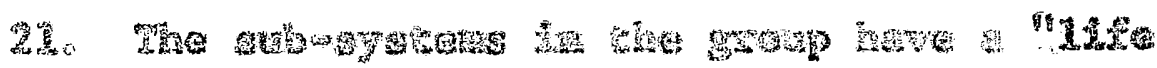
$6 \mathrm{yeg}^{59}$ 


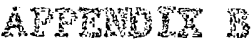

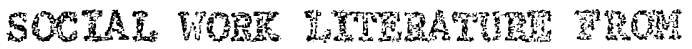

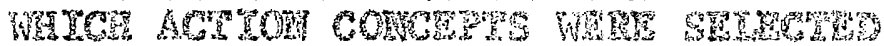

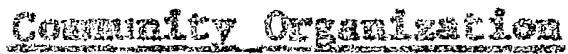

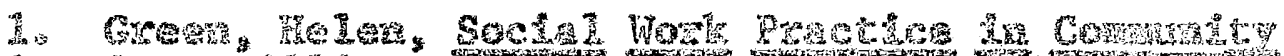

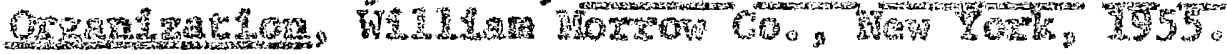

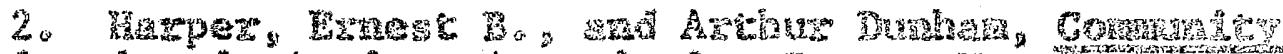

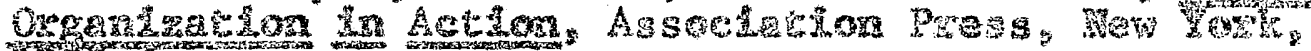
Wy 5 \%

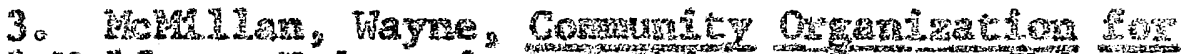

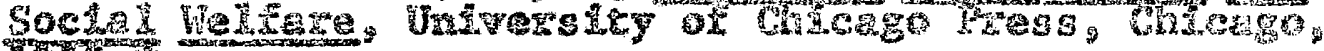

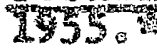

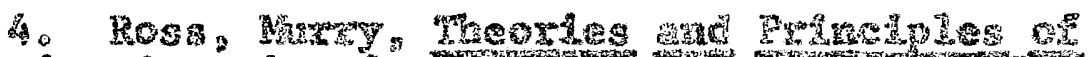

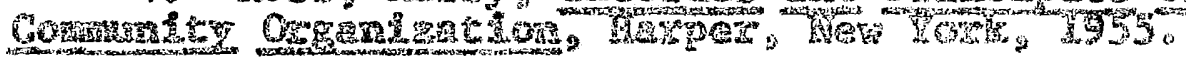

Group Hork

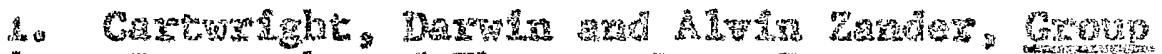

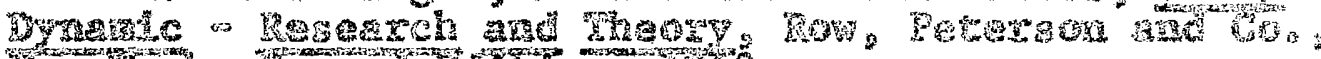

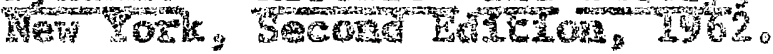

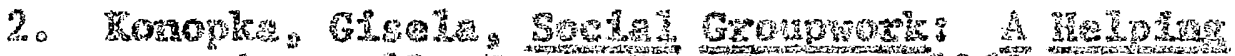

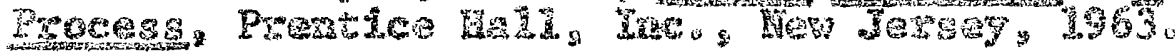

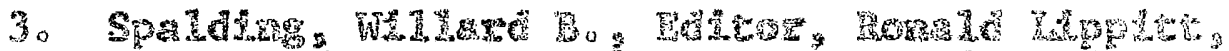

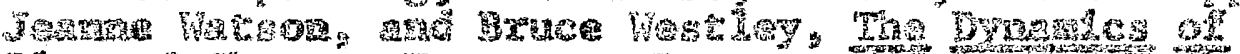

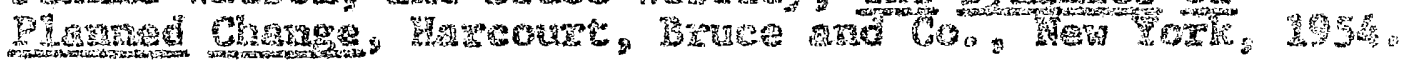

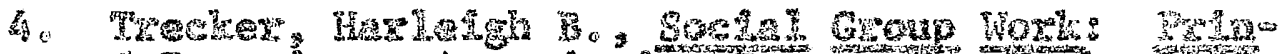

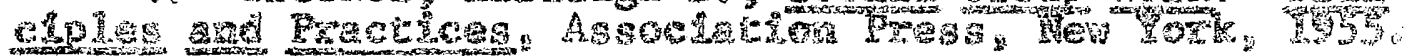

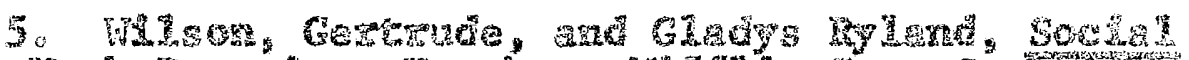

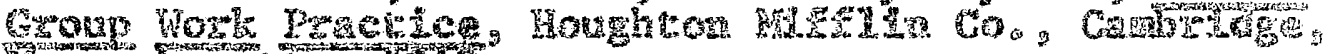
W 
A

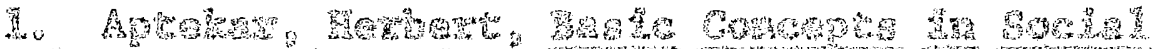

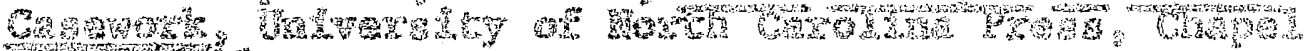
T.

20 Frg

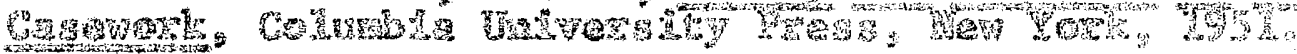

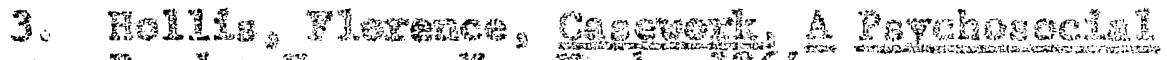

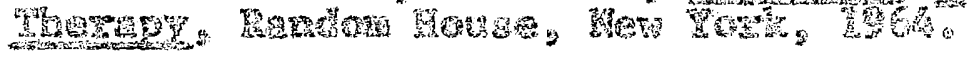

40 Por DH. 


\section{Areng}

\section{ACH}

\section{GORThis:}

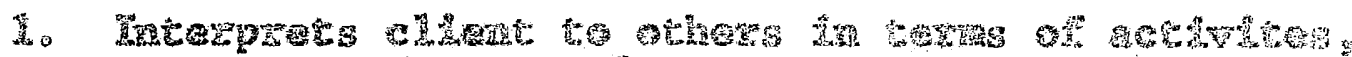

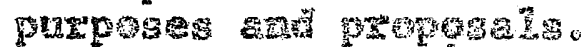

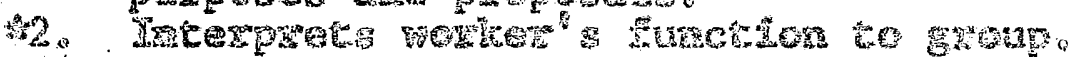

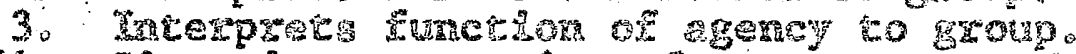

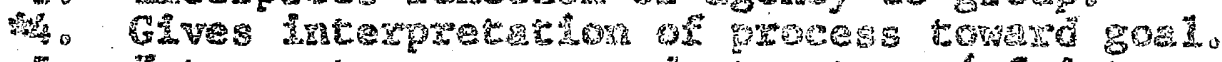

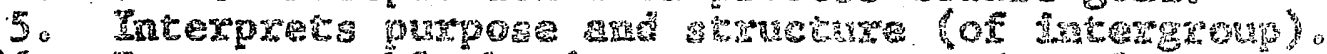

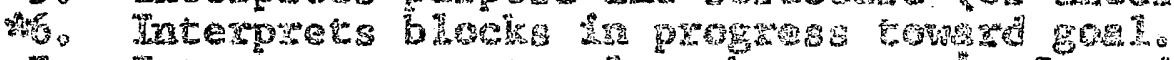

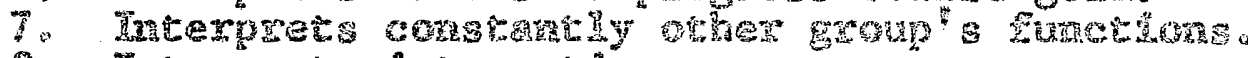

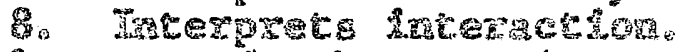

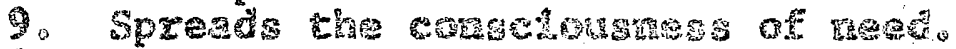

10. Fneourger and

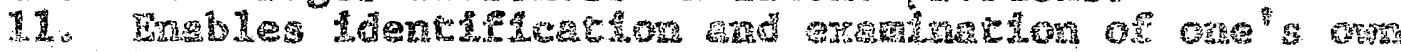

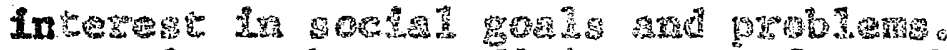

12. Fecognd

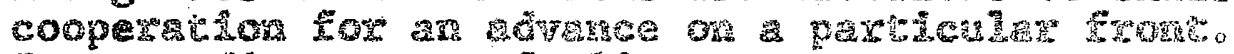

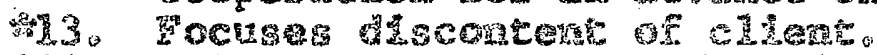

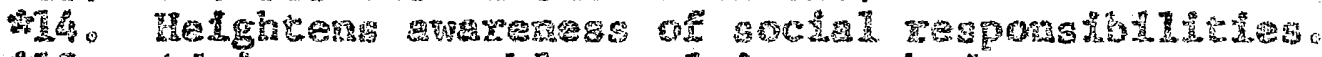

*y. Advises problew

16. Gives suggestaris.

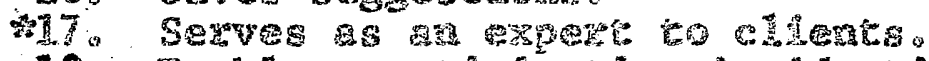

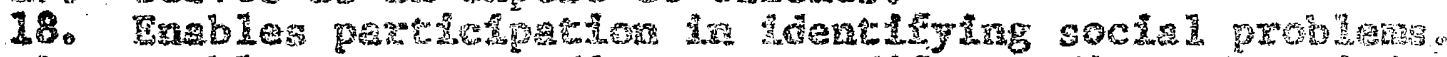

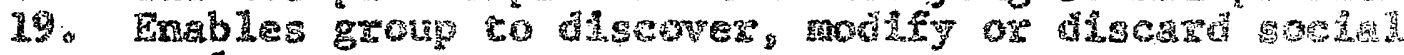
goals.

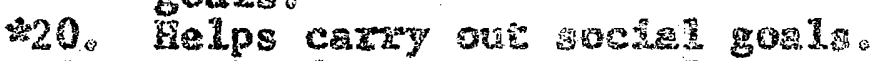

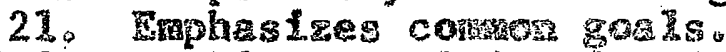

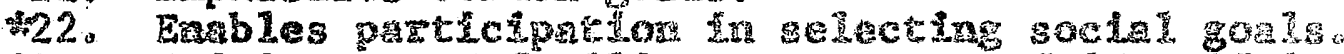

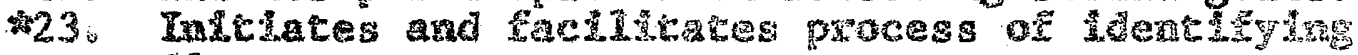
discontent.

24. Fromoces conzeloustass of mead.

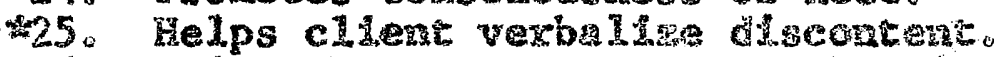

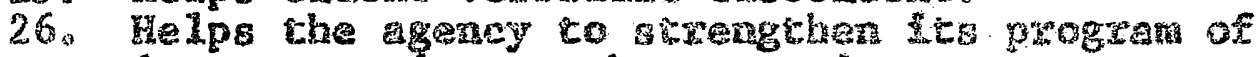

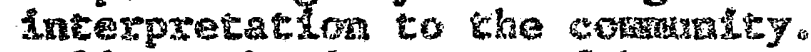

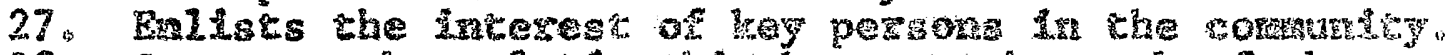

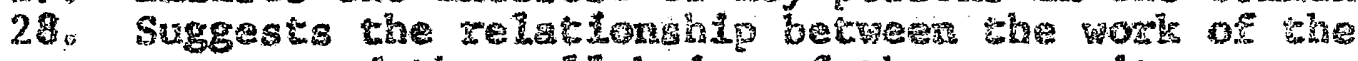
agency and the wellobezig of the condusta.

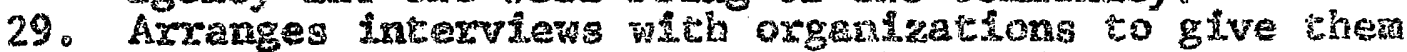
some information about the work or his agency. 
30. Dorat a

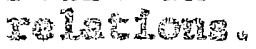

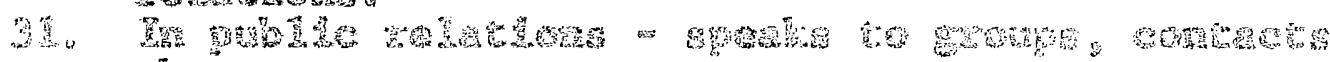
the pras:

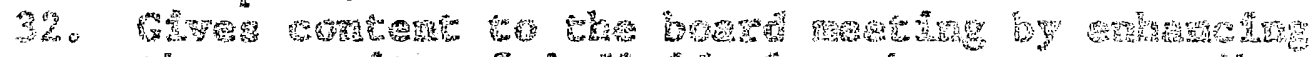

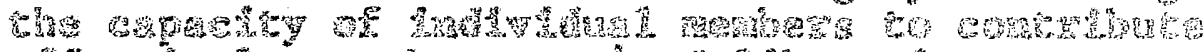
ats

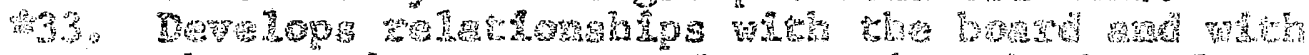

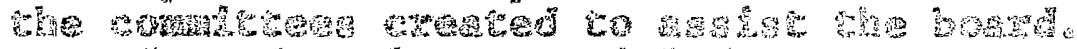

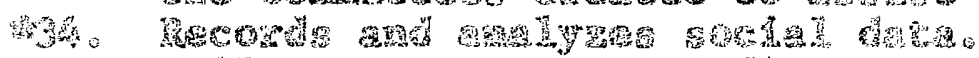

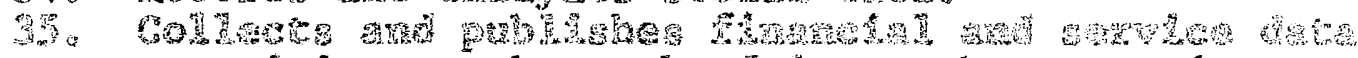
poratrad

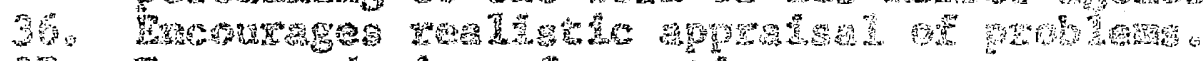

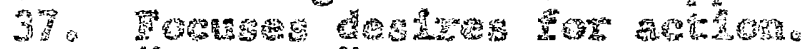

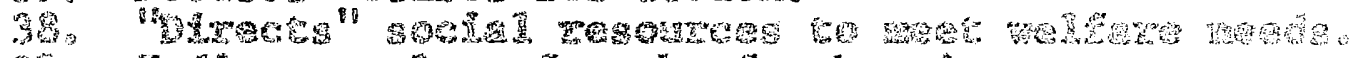

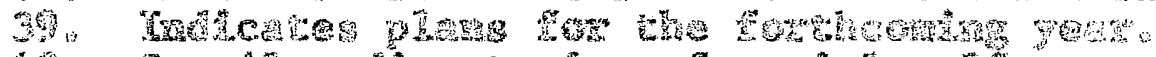

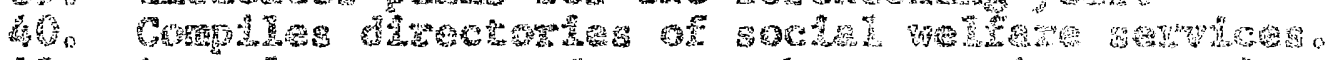

A A A A

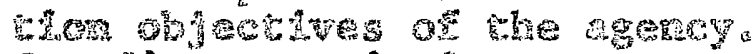

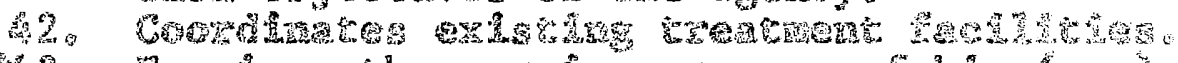

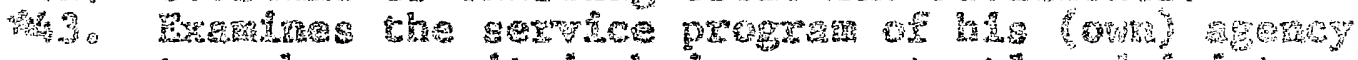

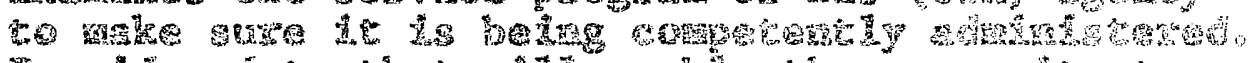

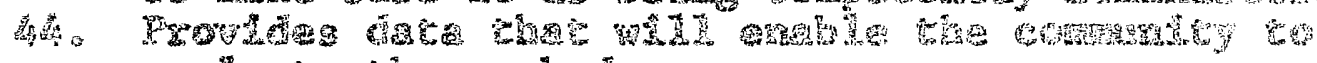
evaluate the morte done.

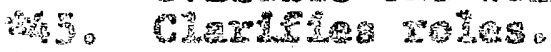

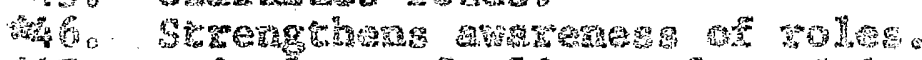

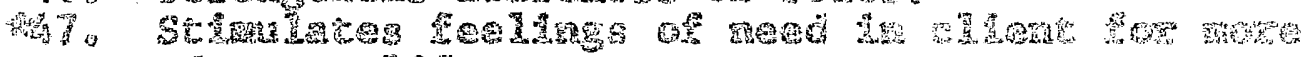

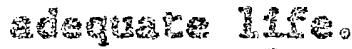

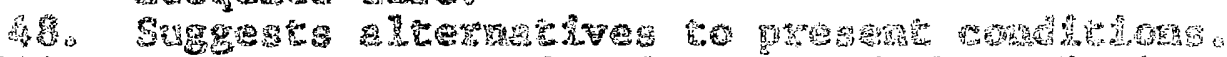

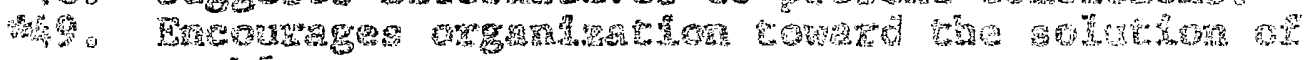

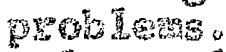

100. HE⿱

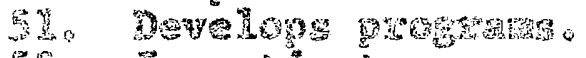

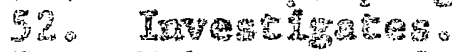

3. Th. Thes

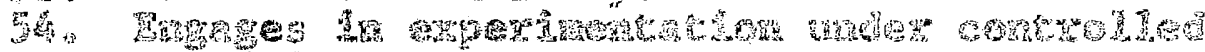

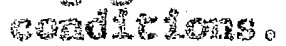

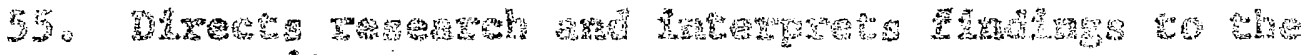
contures.

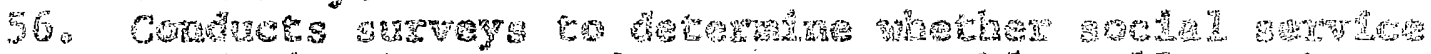

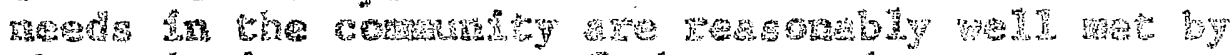

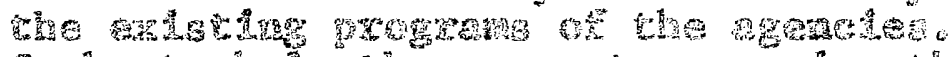

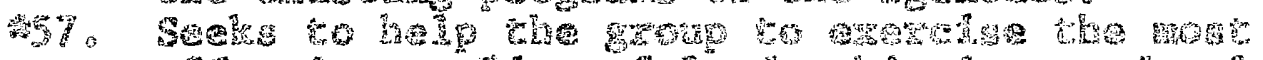

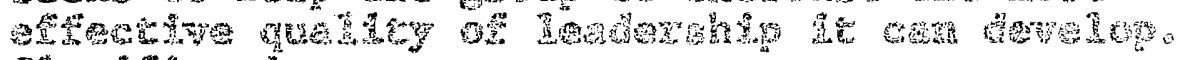

5

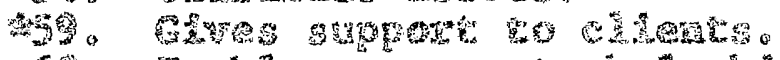

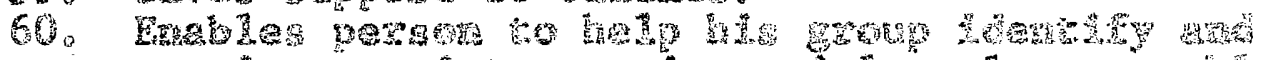

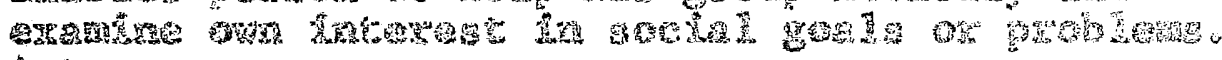

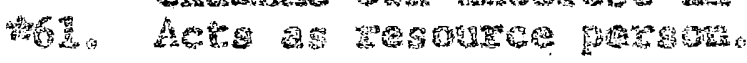




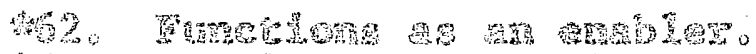

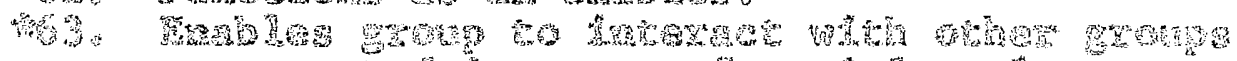

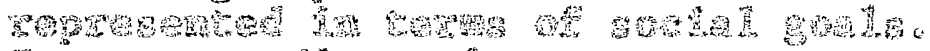

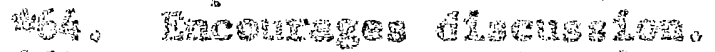

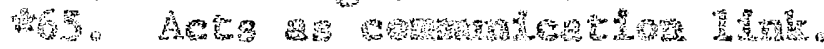

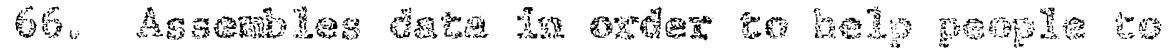

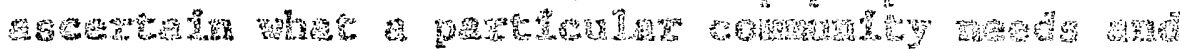

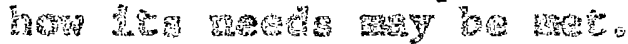

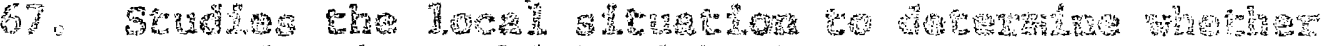

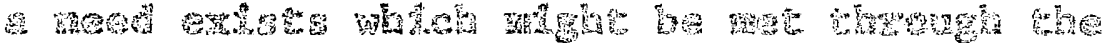

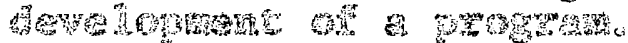

B.

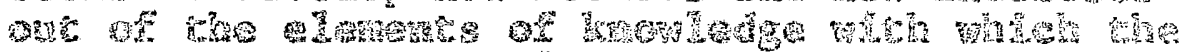

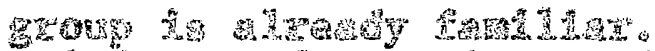

69. Crate

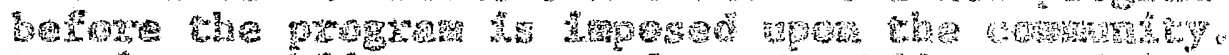

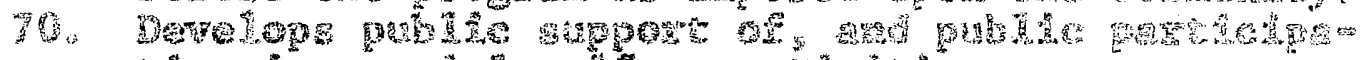

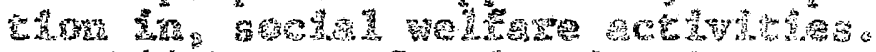

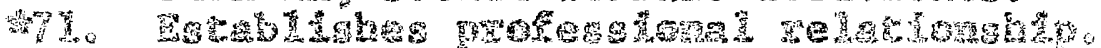

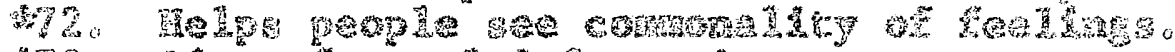

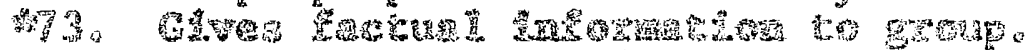

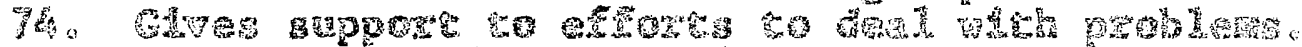

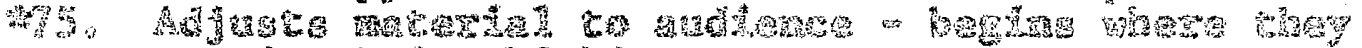

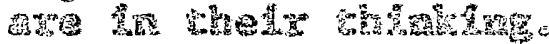

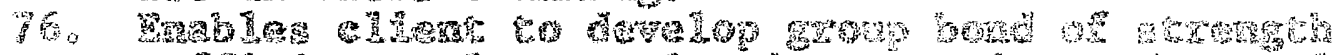
ares

77 .

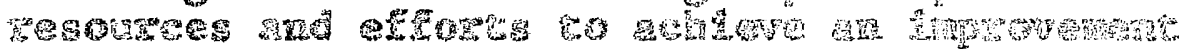

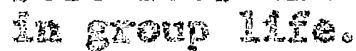

等 prescosis.

*9.

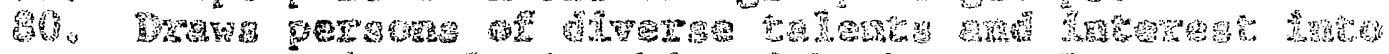

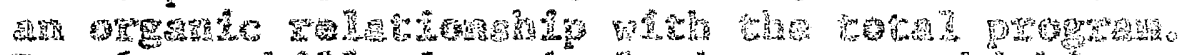

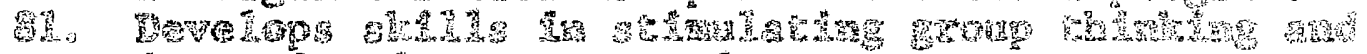

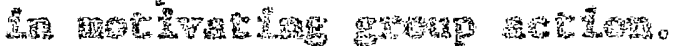

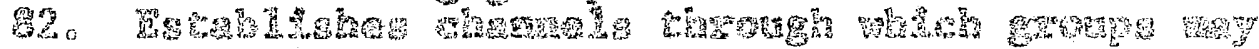

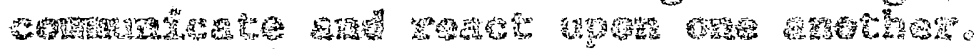

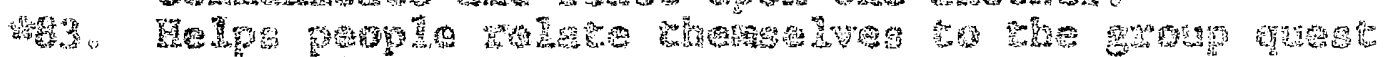
सtras

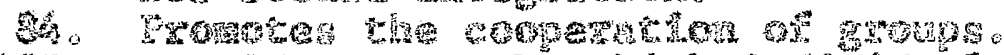

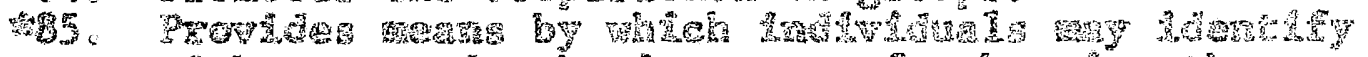

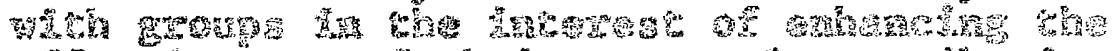

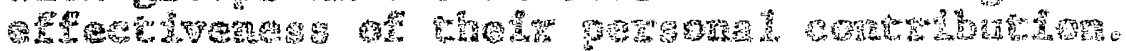

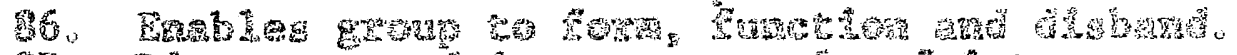

17. Dis 5 sis

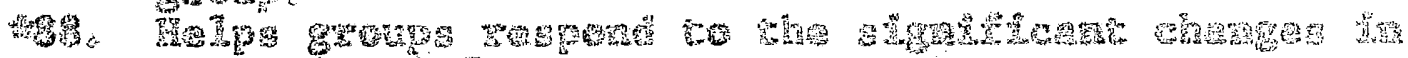

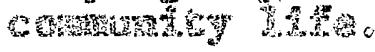




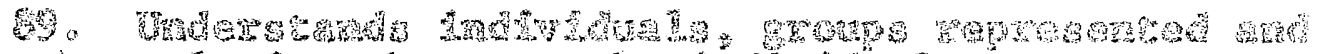

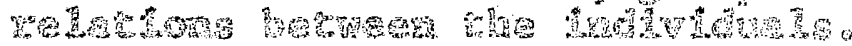

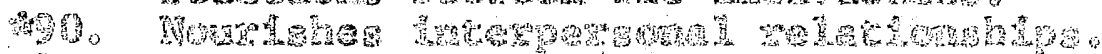

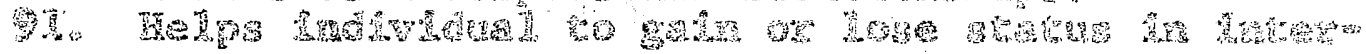

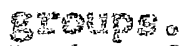

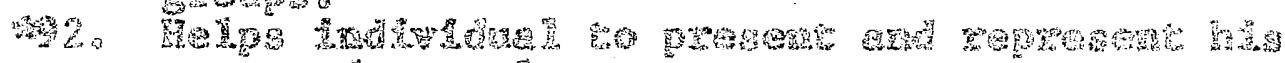

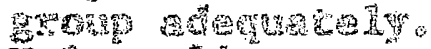

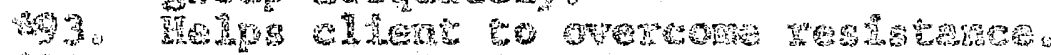

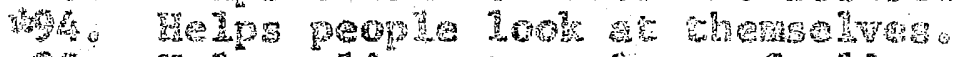

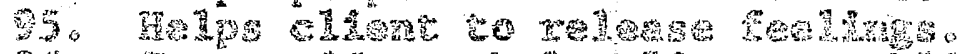

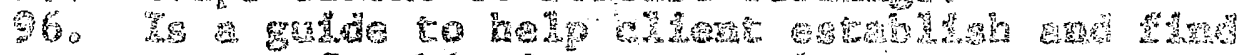
g

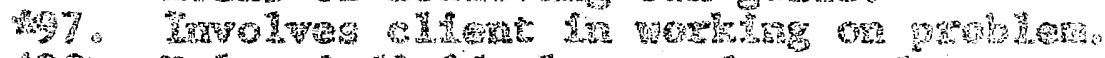

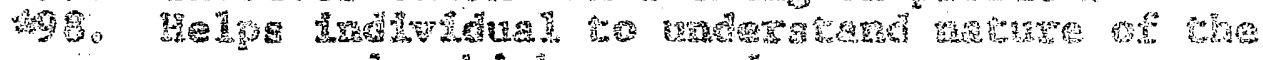

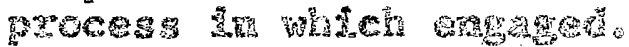

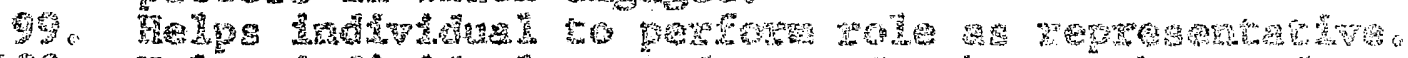

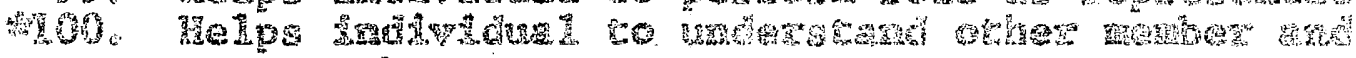
grongs they rapregere.

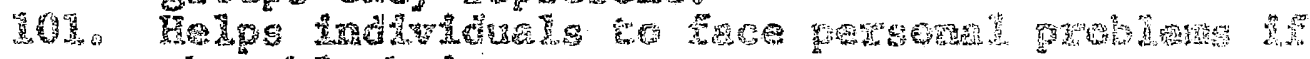

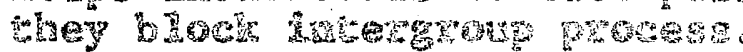

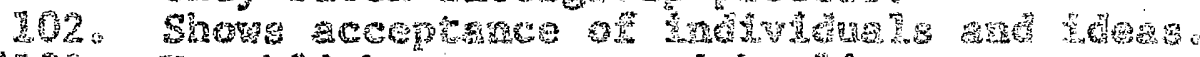

mor

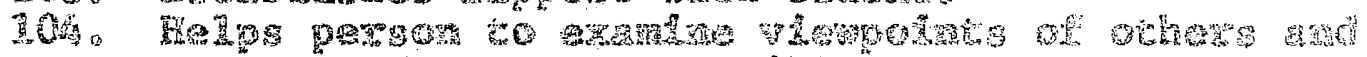

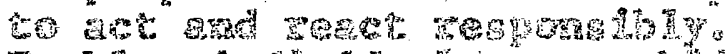

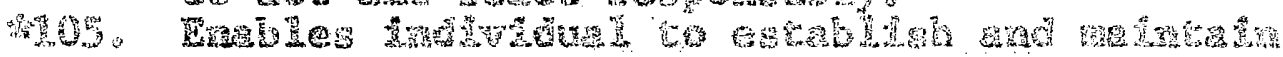

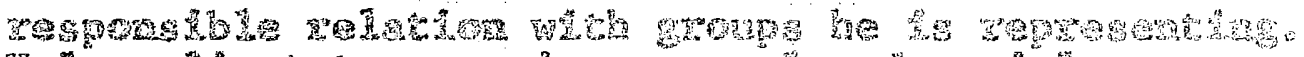

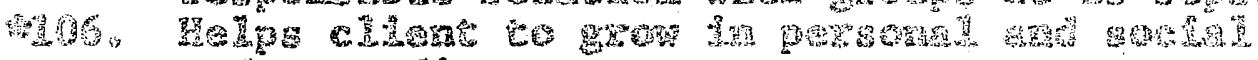

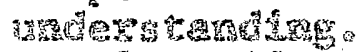

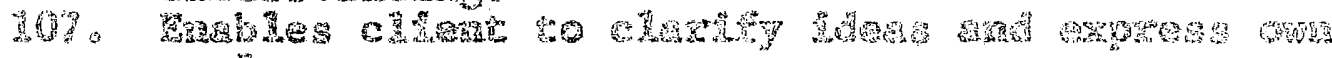

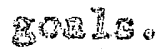

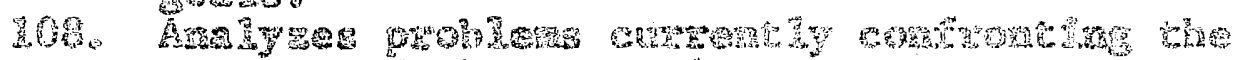

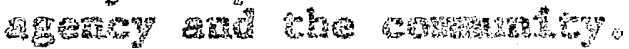

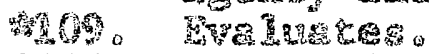

4D

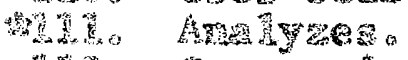

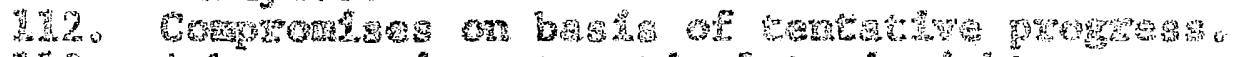

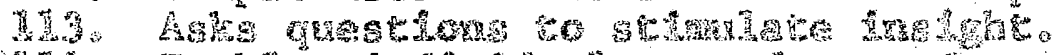

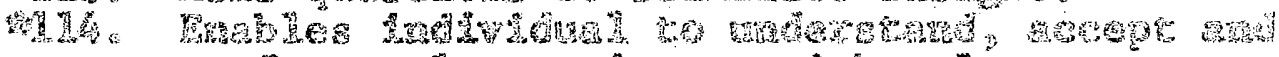

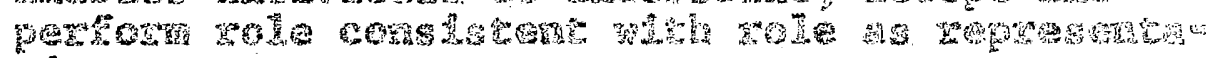
trive.

15. Adrow

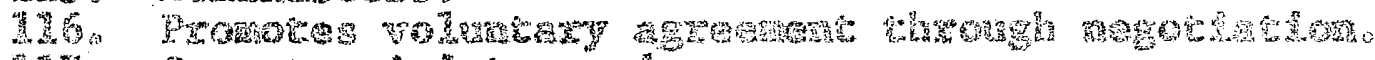

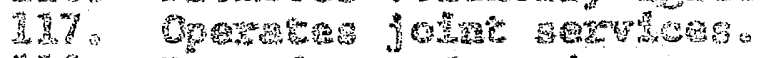

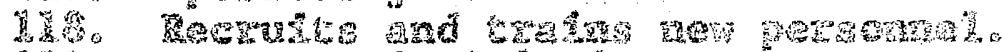

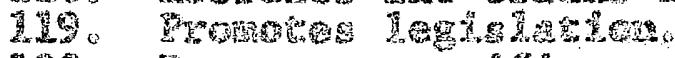

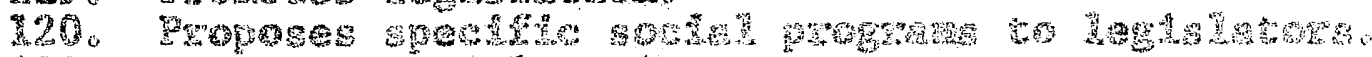

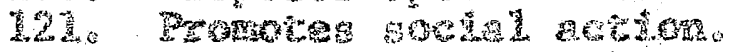

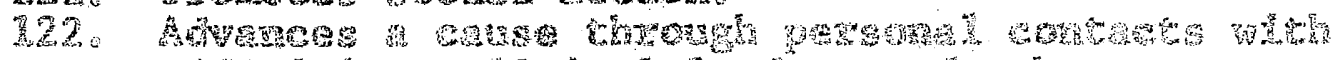

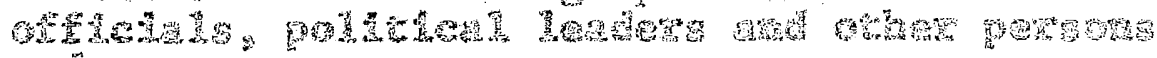

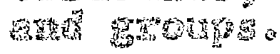




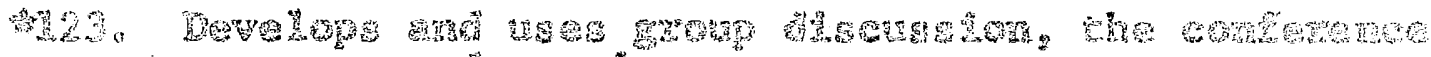

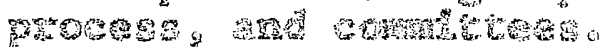

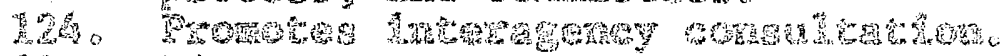

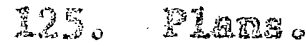

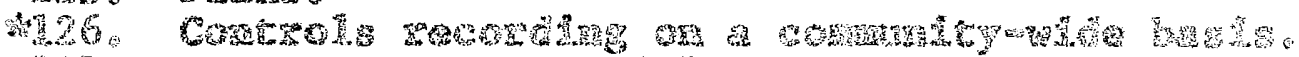

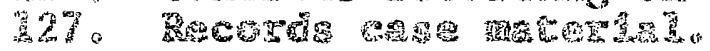

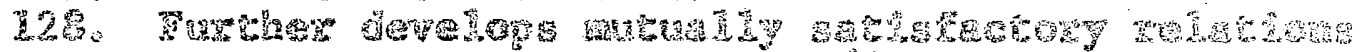

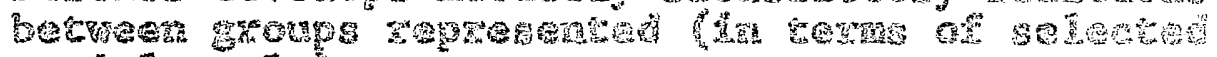

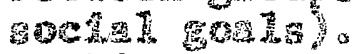

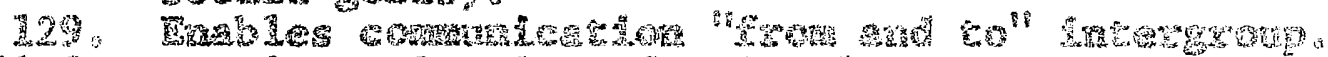

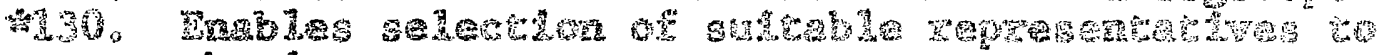

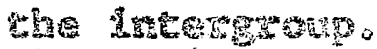

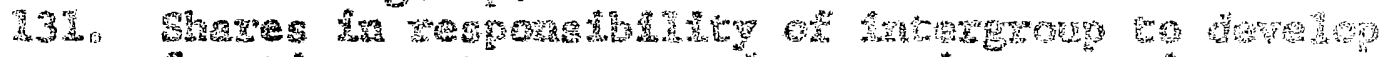

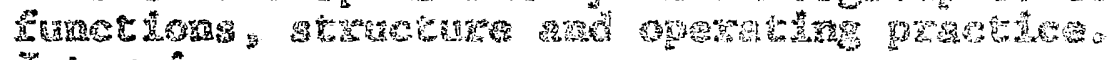

132. Theservieng

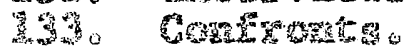

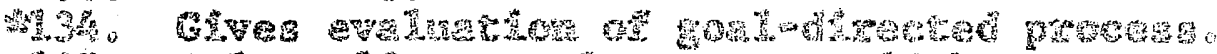

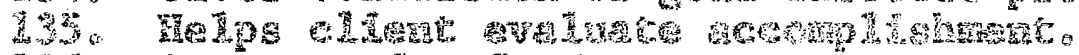

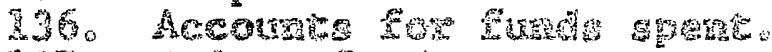

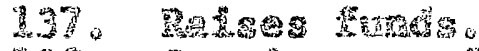

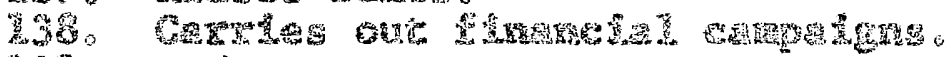

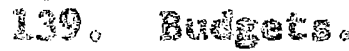

Crrags Woyer

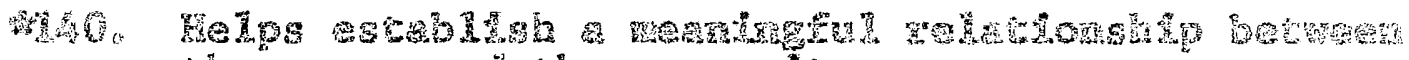

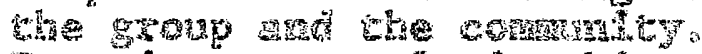

1.

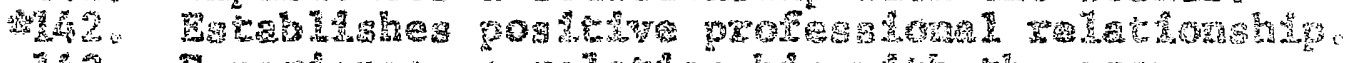

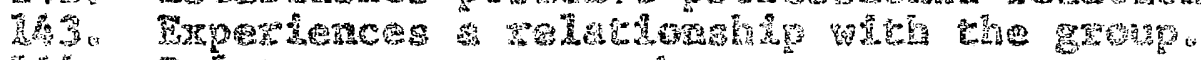

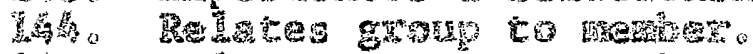

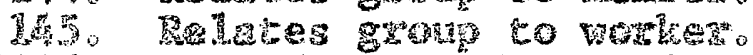

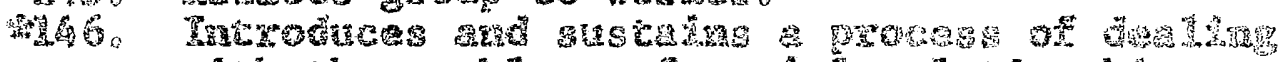

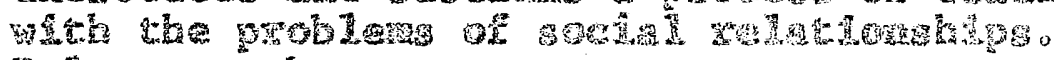

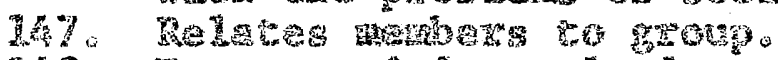

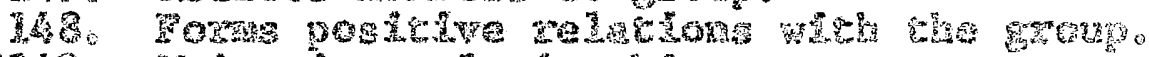

\%

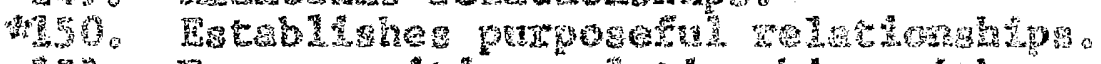

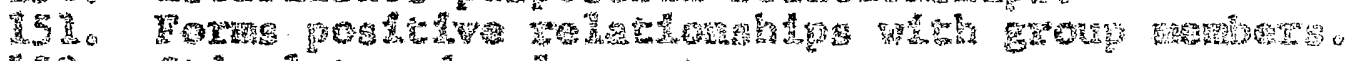

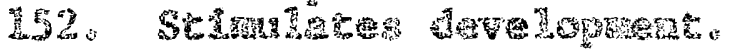

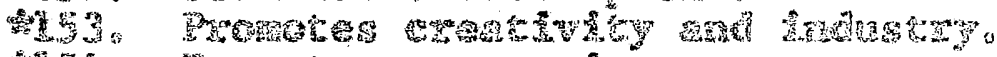

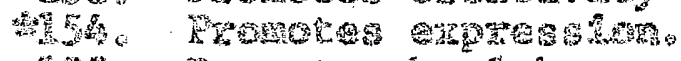

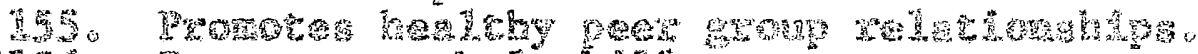

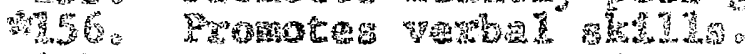

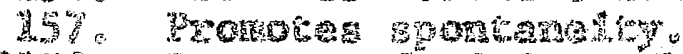

W

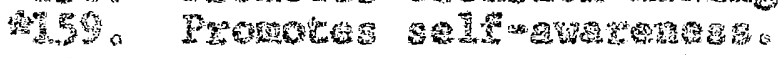




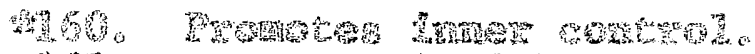

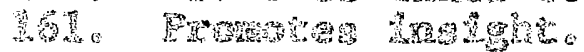

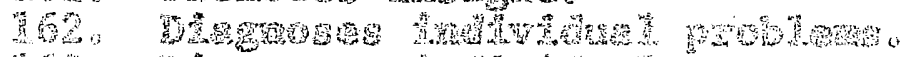

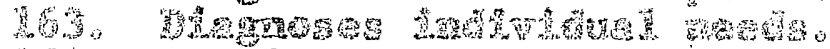

等

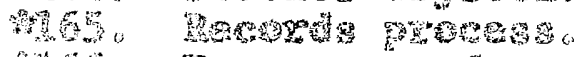

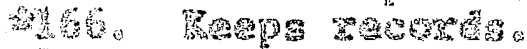

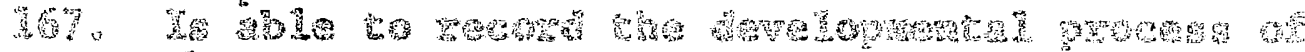

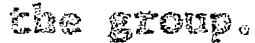

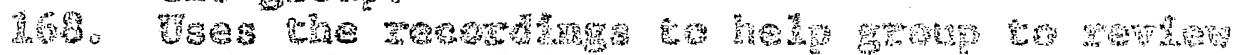

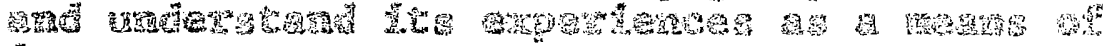
I

IS

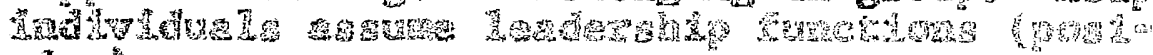
Fition

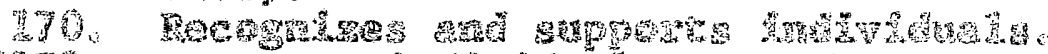

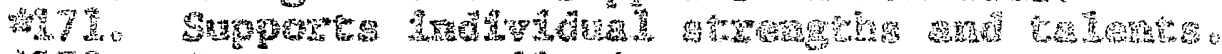

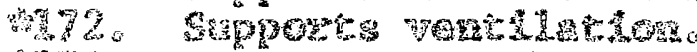

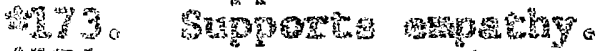

4.

$17 \%$ Wupprets

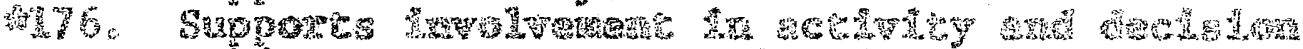

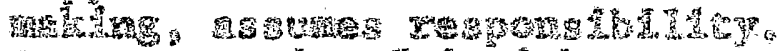

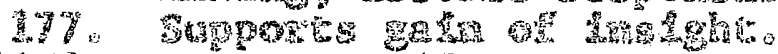

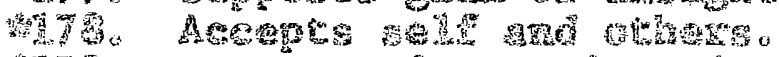

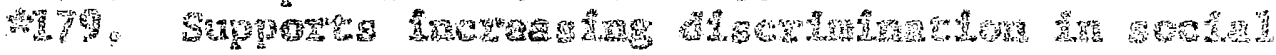
xesponat.

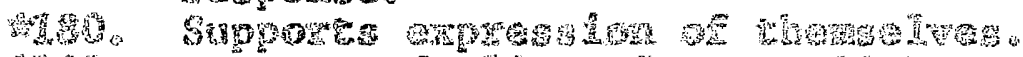

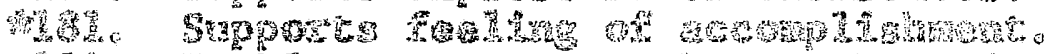

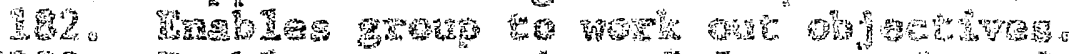

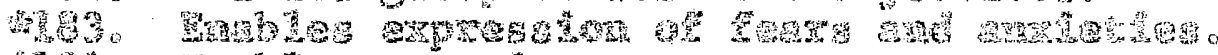

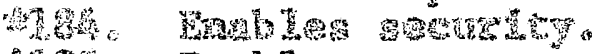

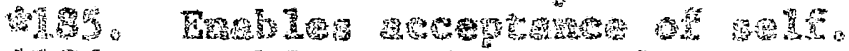

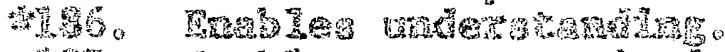

落

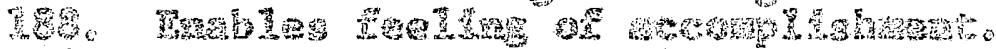

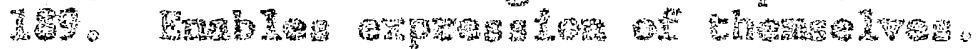

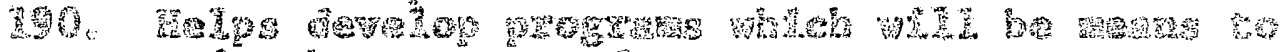
s.t.

4hy

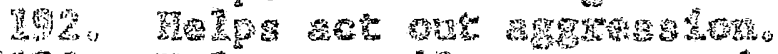

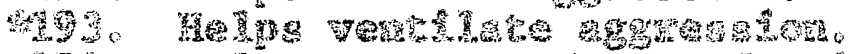

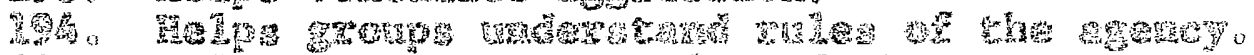

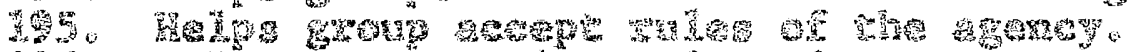

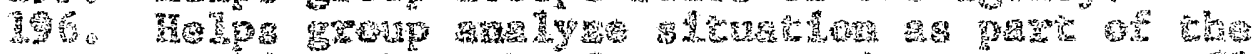
Wf

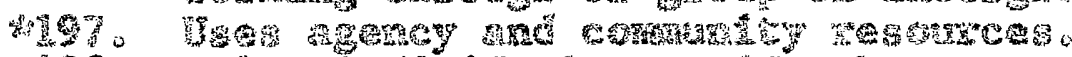

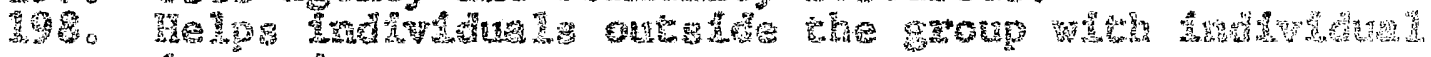

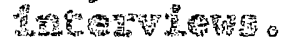




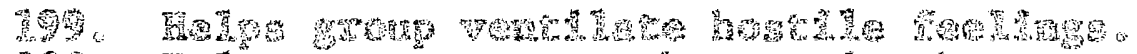

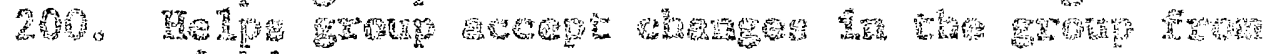

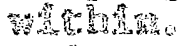

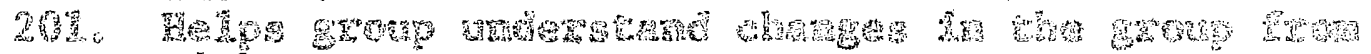

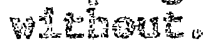

$20 \%$ \%

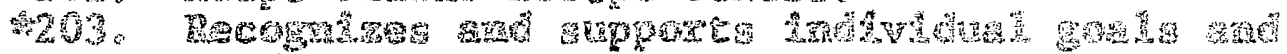

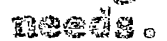

20, Wo

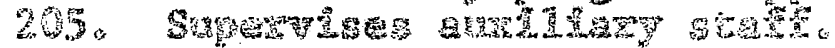

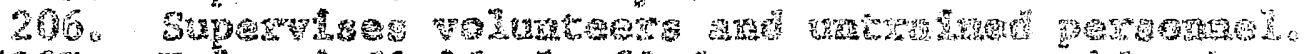

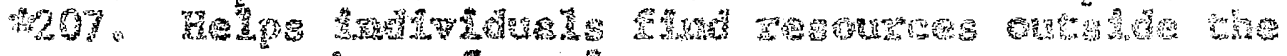

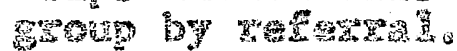

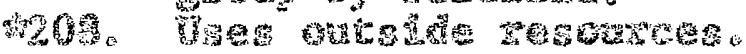

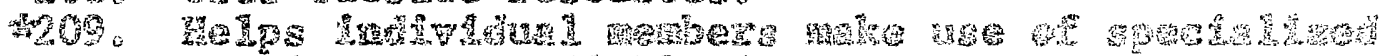

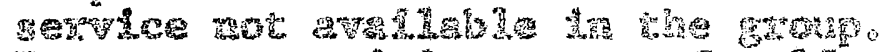

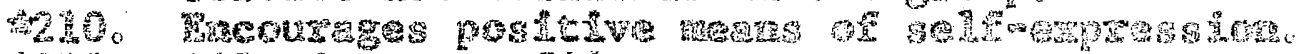

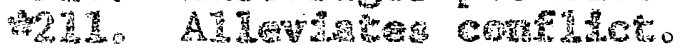

*212。 A H

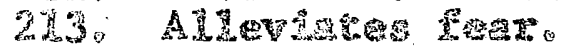

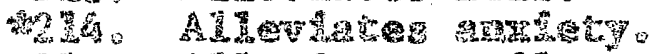

2. A

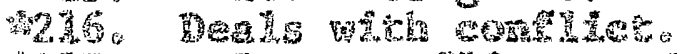

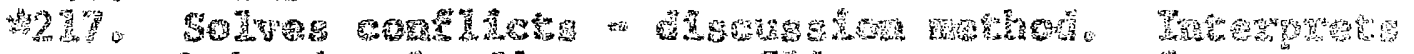

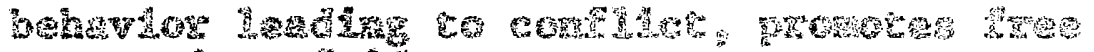

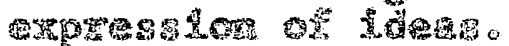

2. 19. Re

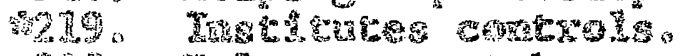

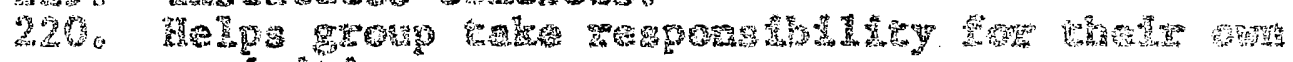

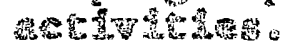

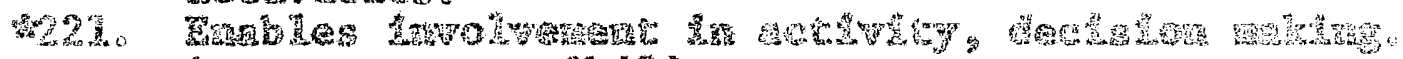
ALS

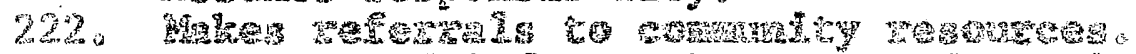

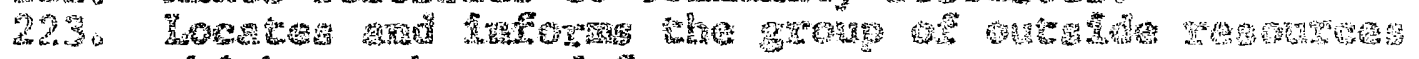
7\%

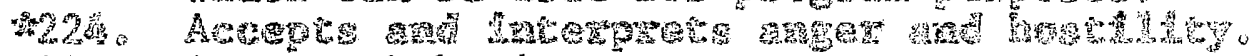

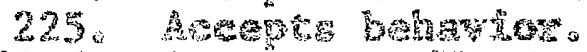

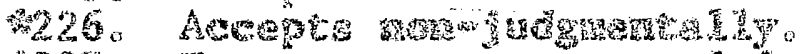

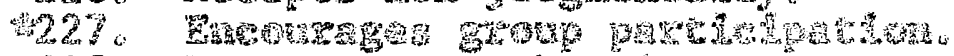

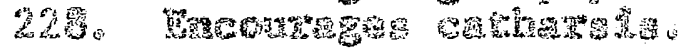

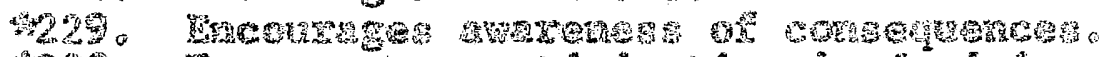

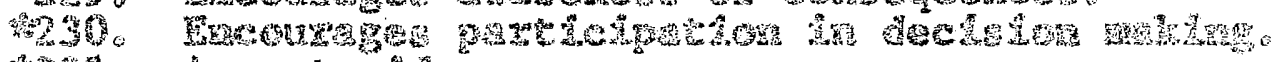

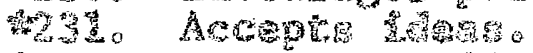

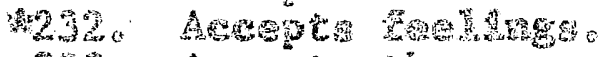

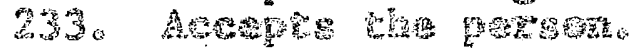

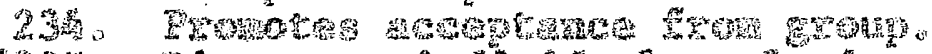

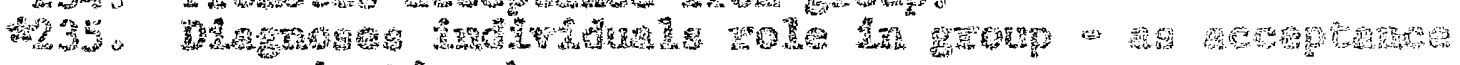

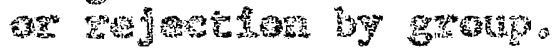


230. WR

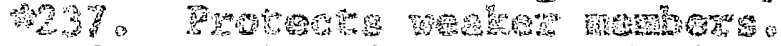

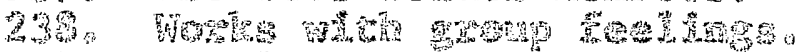

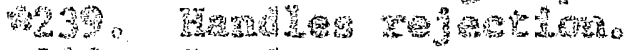

2月10. Tsis

2.

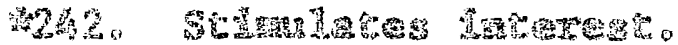

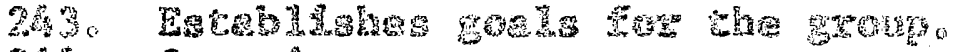

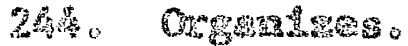

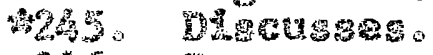

246. Porgres?

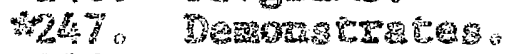

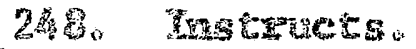

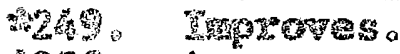

$255 \%$ AE:

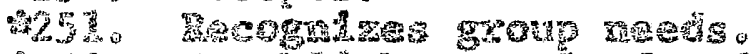

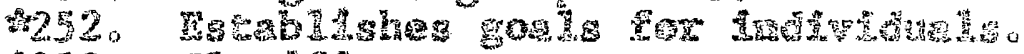

253,84250

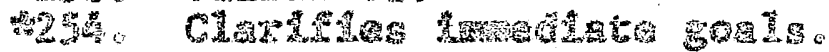

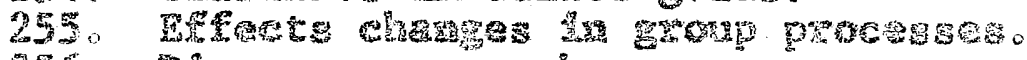

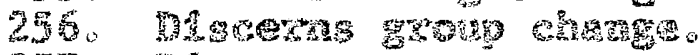

42

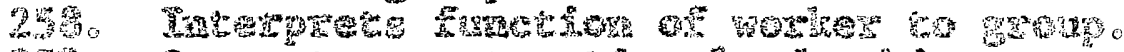

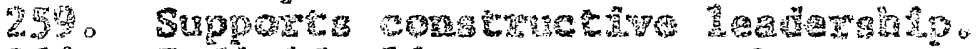

260 Tox

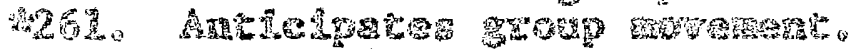

262。 Morrin

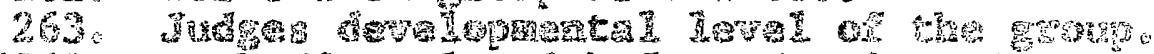

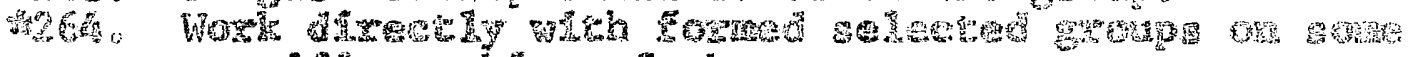
Barg

267. ArE⿺

260. Evas

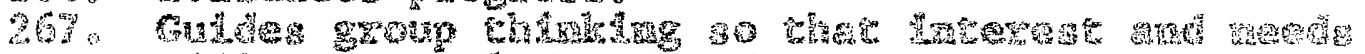

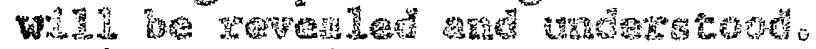

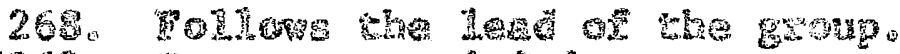

20.

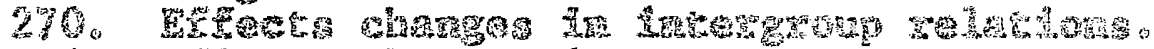

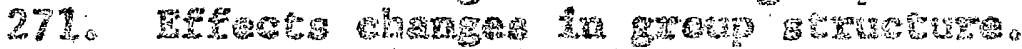

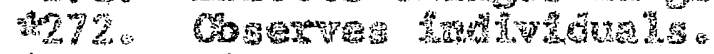

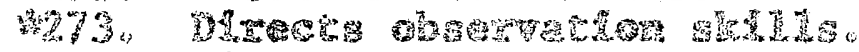

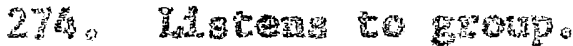

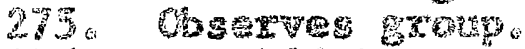

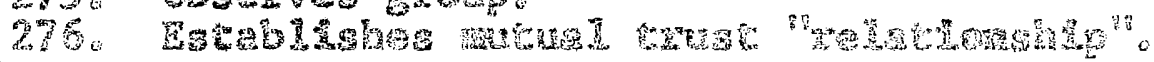

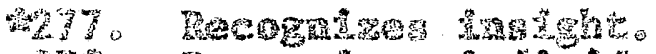

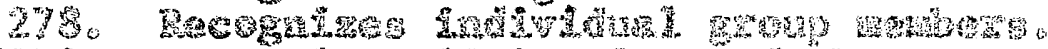

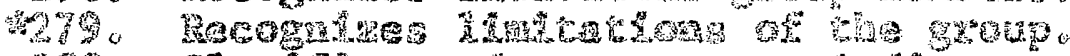

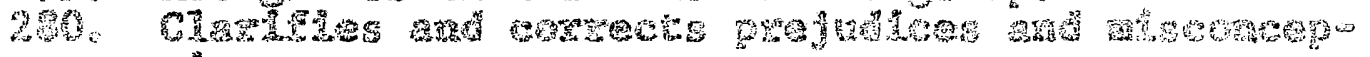
ctons: 


\section{istion}

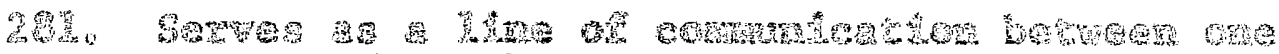

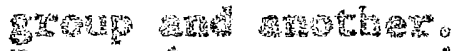

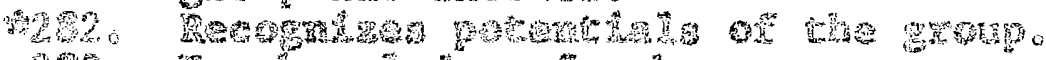

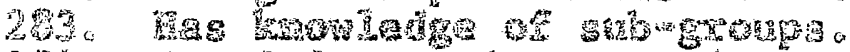

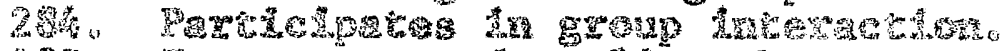

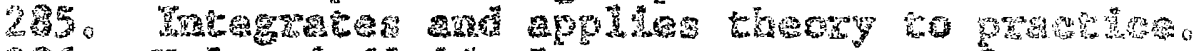

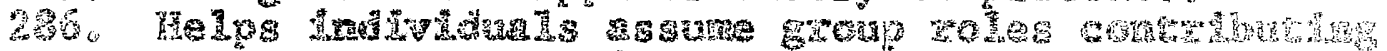
to the gronps deve

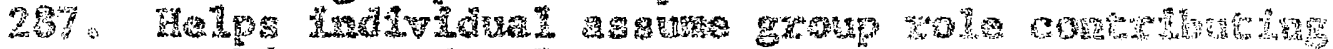
to his ow develowernt.

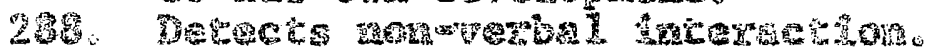

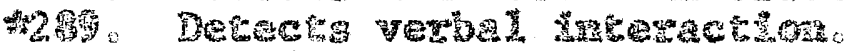

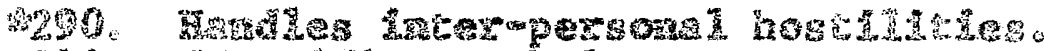

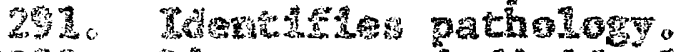

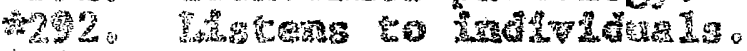

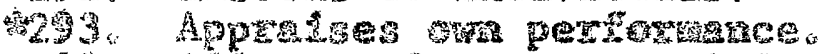

29.4A A

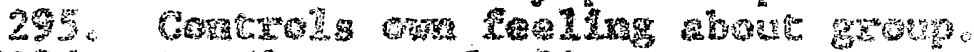

42.

R2 2 \%。

+29.

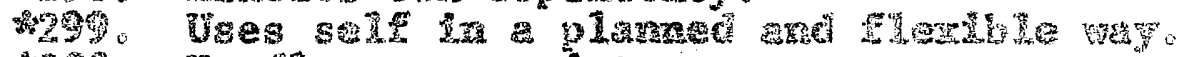

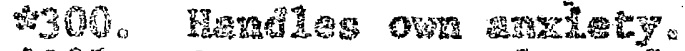

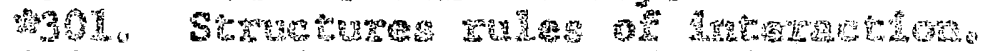

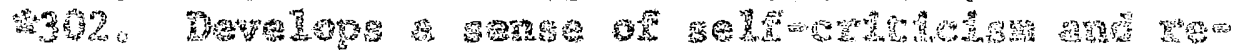

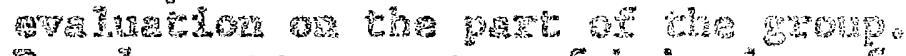

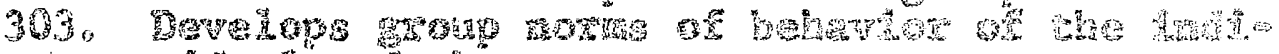

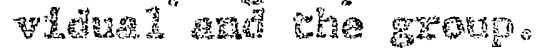

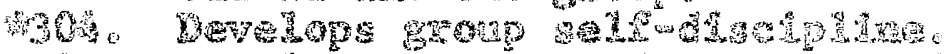

305. There

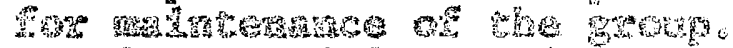

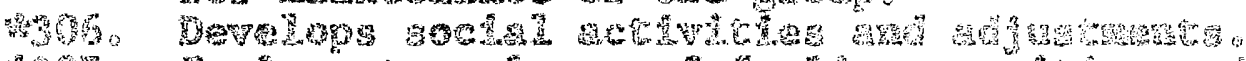

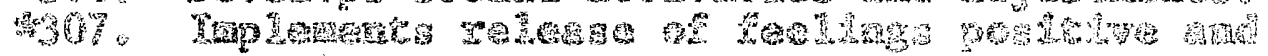
sergetwe.

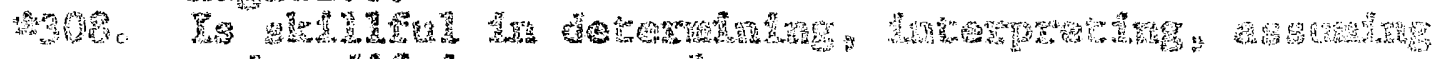
and w

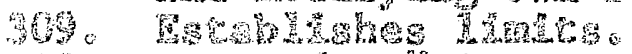

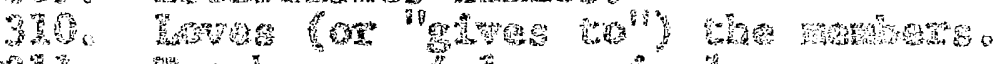

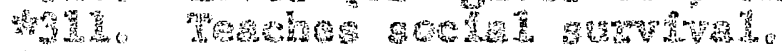

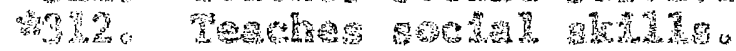

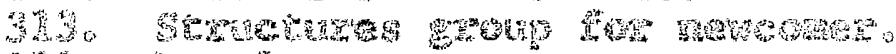

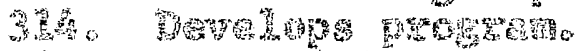

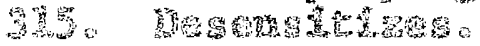

45

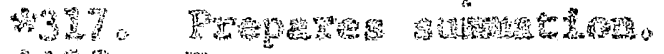

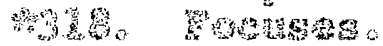

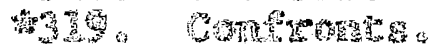




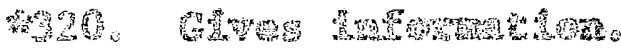

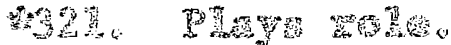

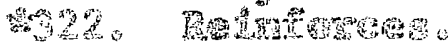

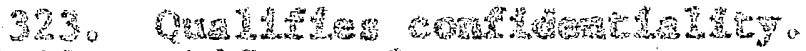

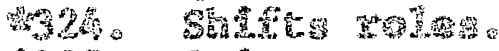

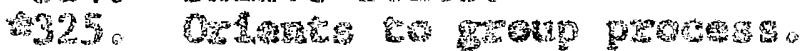

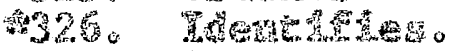

औ?

\section{GSW}

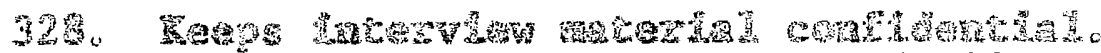

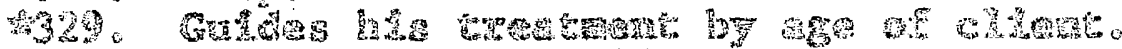

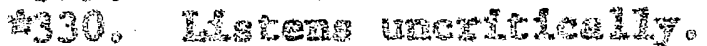

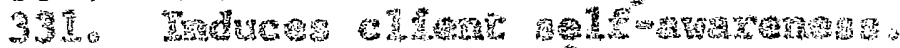

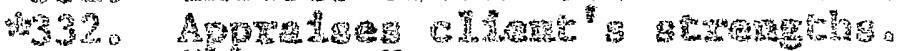

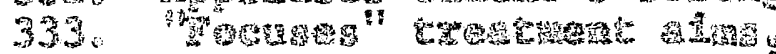

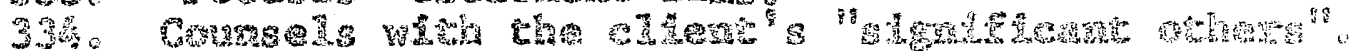

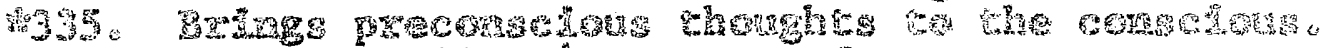

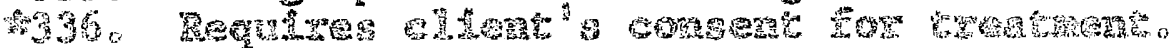

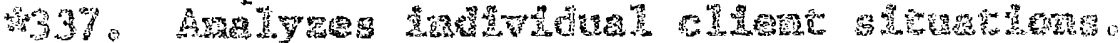

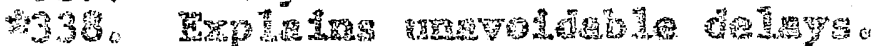

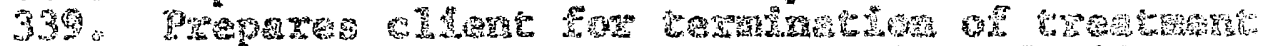

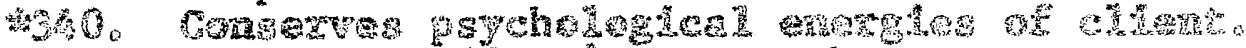

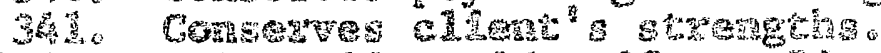

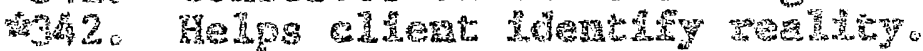

43.

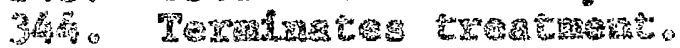

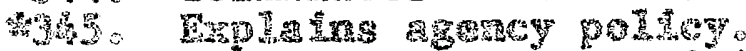

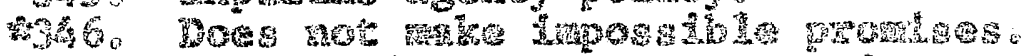

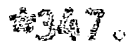

速籍。

369

35

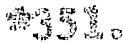

35

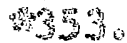

$3 \mathrm{~S}^{\mathrm{B}}$

Wha

35

39

35 战。

359

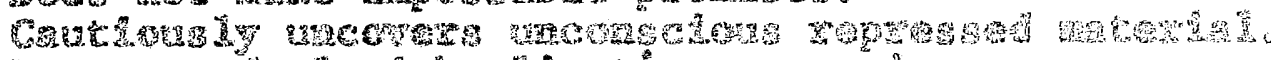

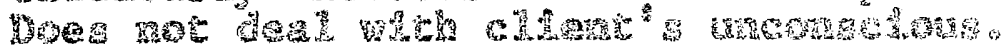

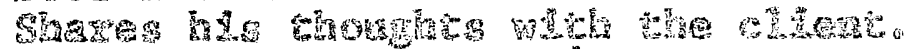

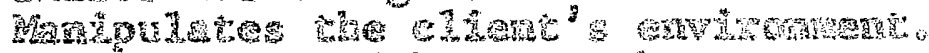

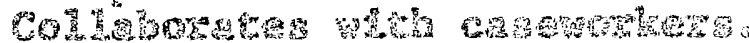

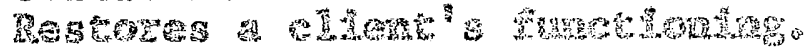

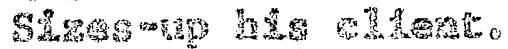

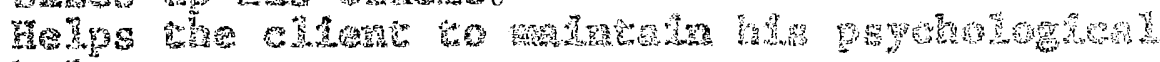

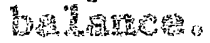

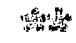

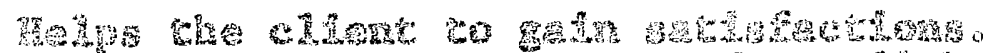

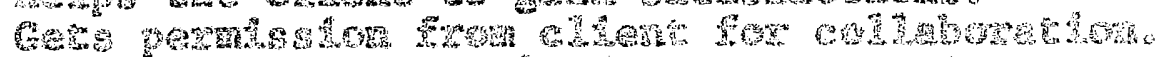

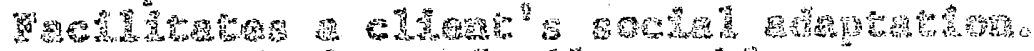

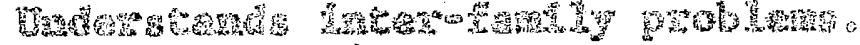

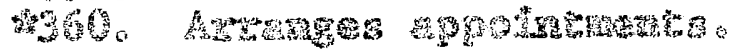




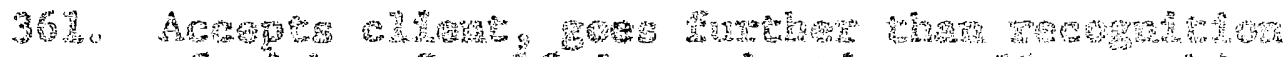

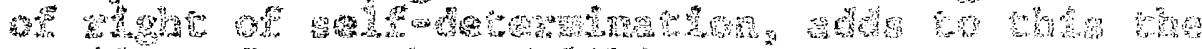

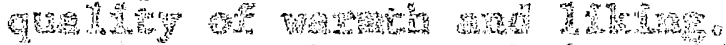

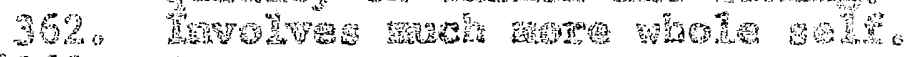

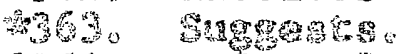

Wh

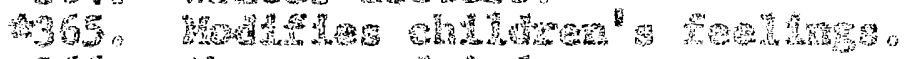

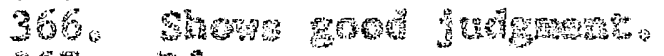

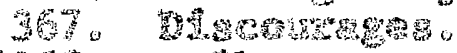

H.

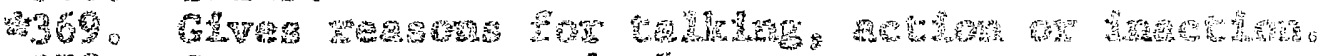

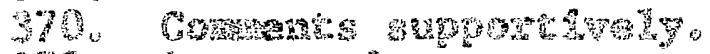

3月. A A

W

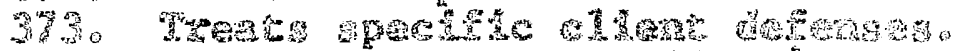

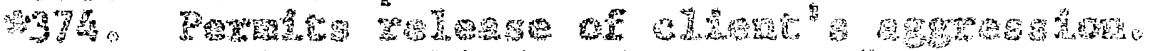

sy.

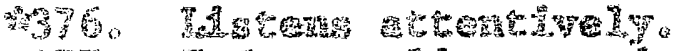

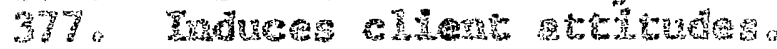

4hy 8. A

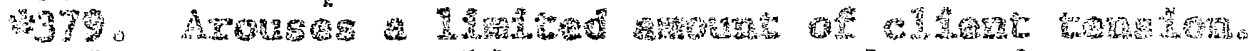

380, Rad

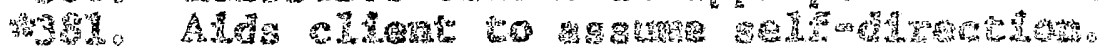

\% 곤

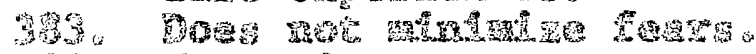

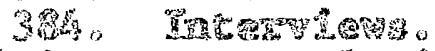

4385. 75 s

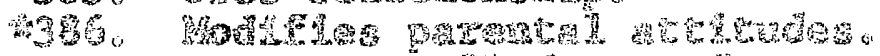

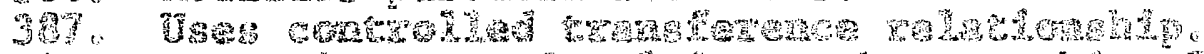

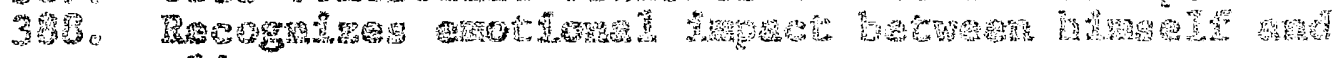
aliente.

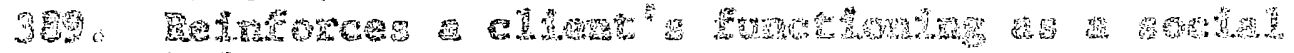
Wat

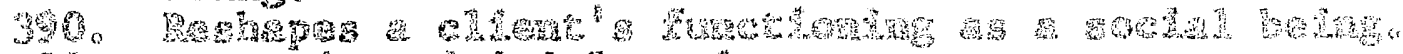

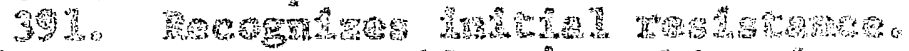

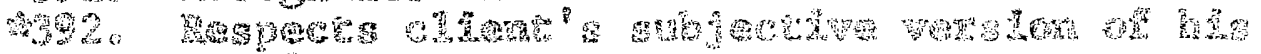

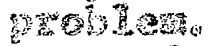

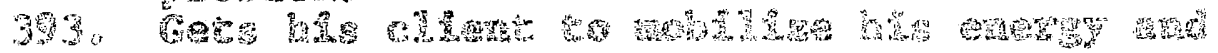
3as

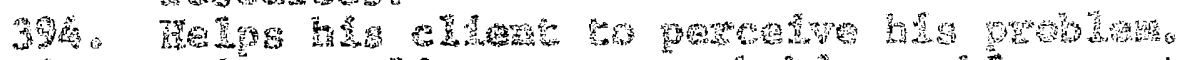

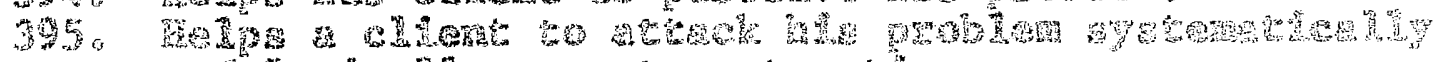

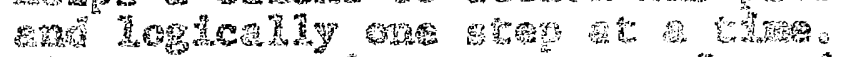

396.72 reas

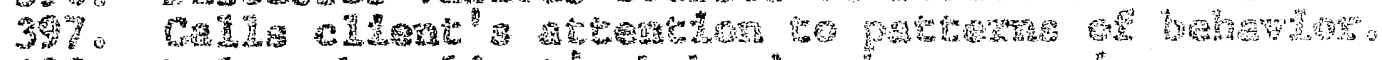

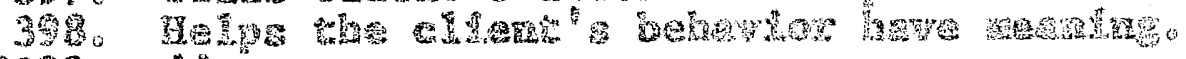

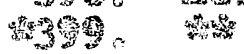




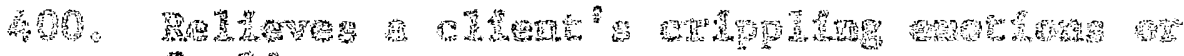

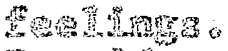

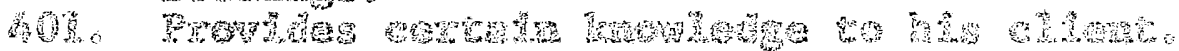

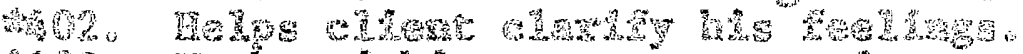

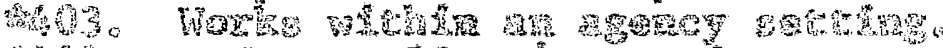

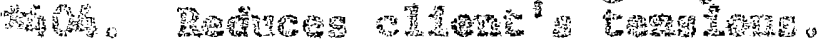

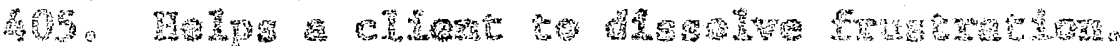

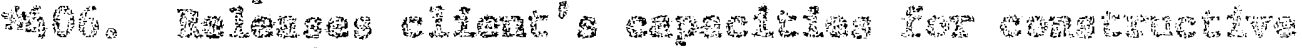
beras?

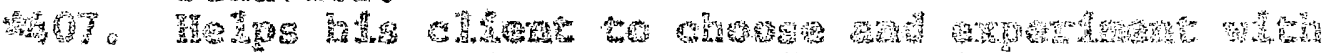

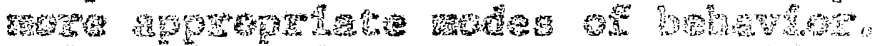

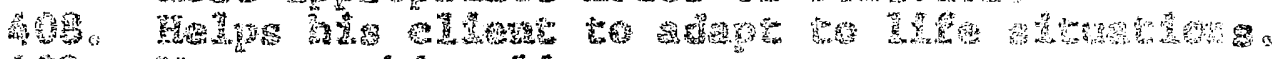

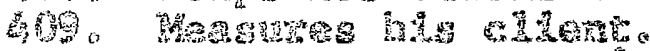

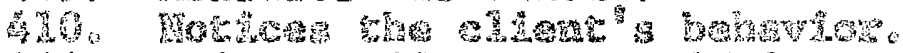

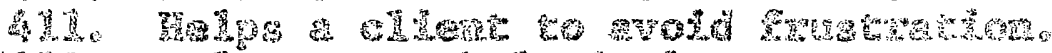

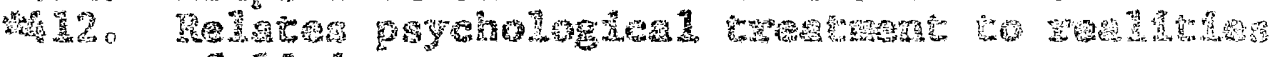

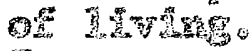

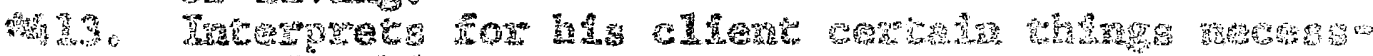

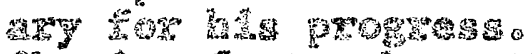

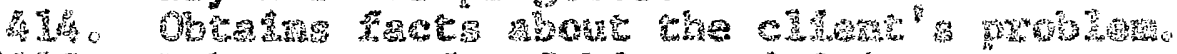

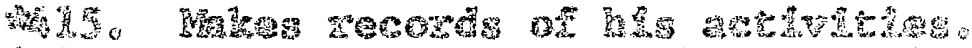

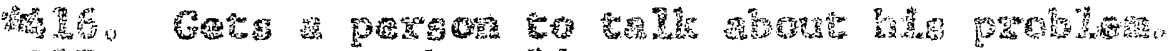

finto Suppores the ellonto

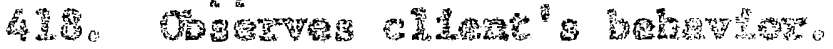

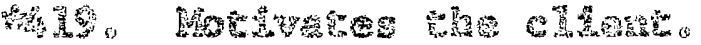

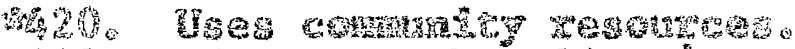

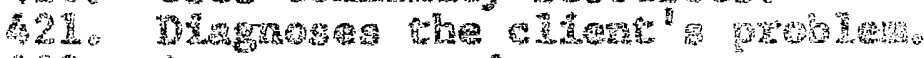

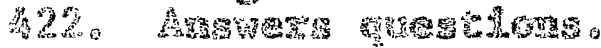

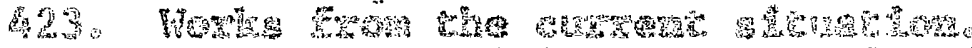

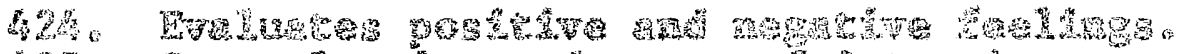

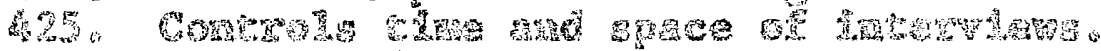

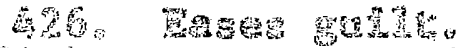

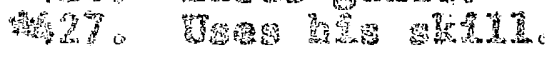

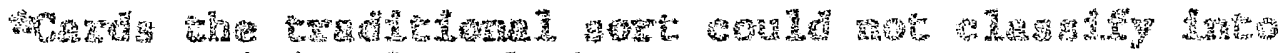

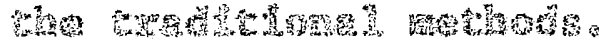

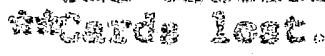




\section{GEA}

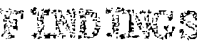

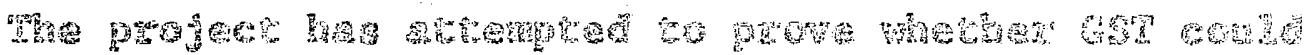

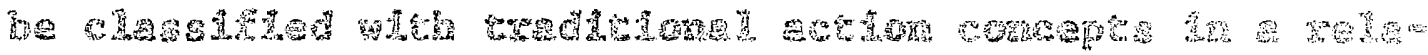

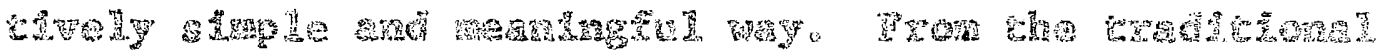

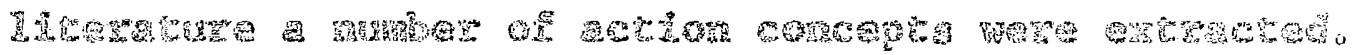

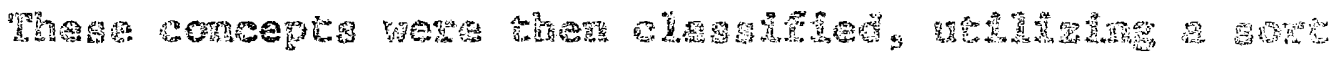

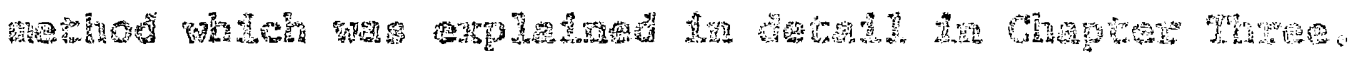

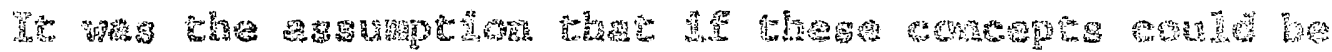

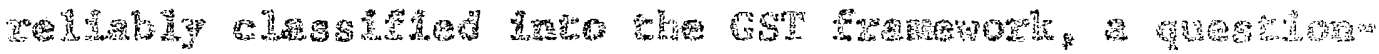

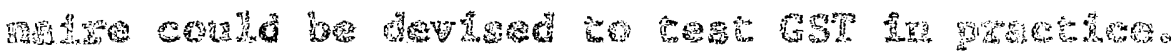

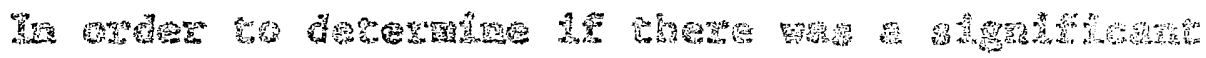

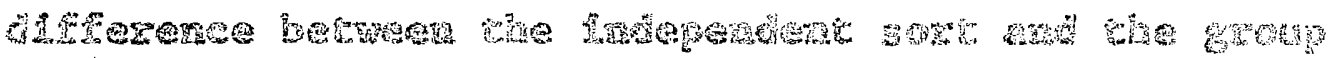
30\%

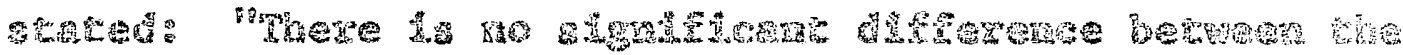

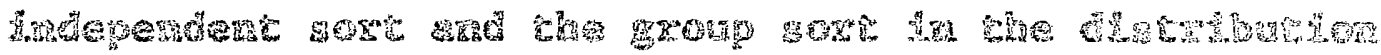

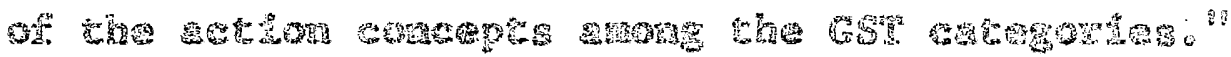

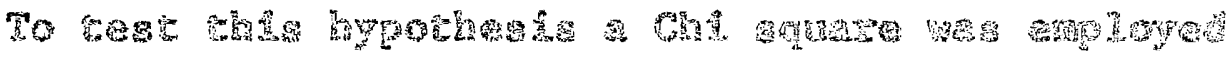

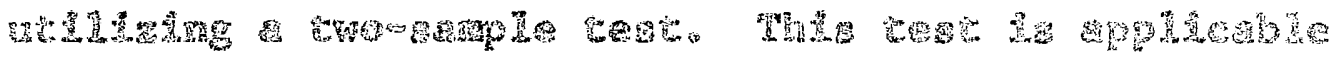

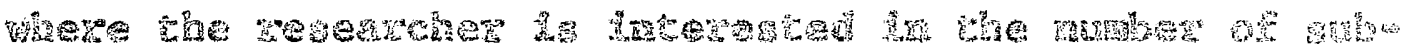

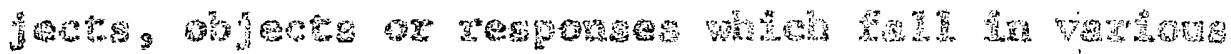

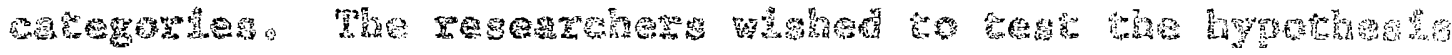

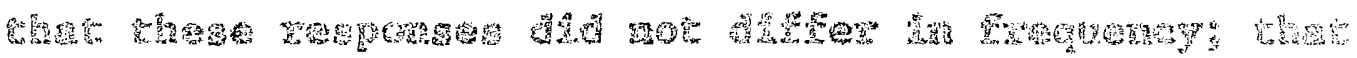


AN.

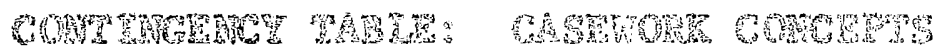

\begin{tabular}{|c|c|c|c|c|c|c|c|}
\hline & w & 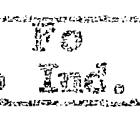 & 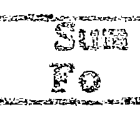 & $\begin{array}{l}\text { Te } \\
\text { Syous }\end{array}$ & $2^{2}$ & 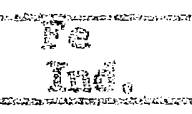 & $x^{2}$ \\
\hline 直 & 7 & 82 & 69 & 6.09 & .218 & 62.95 & $.9 \mathrm{H}$ \\
\hline 2 & 2 & 33 & 35 & 3.08 & .38 & 34.92 & 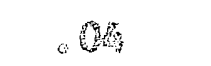 \\
\hline 3 & 基 & 35 & 56 & 4.93 & 30.3 & $30.0 \%$ & .30 \\
\hline 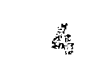 & 6 & 63 & 63 & 6.96 & .00 & 62.93 & .00 \\
\hline 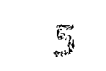 & 禹 & 98 & 96 & 2. & .69 & $35: 72$ & .06 \\
\hline$b$ & 息 & 29 & 29 & 2,3 & .90 & 26.9 & .20 \\
\hline$y$ & 0 & 蛋 & 21 & 。 & 68 & 30.04 & .10 \\
\hline 㱐 & 3 & $2 y$ & 56 & 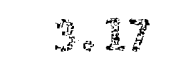 & 30.22 & 32.83 & 䈍。品 \\
\hline$y$ & 2 & 6 & 8 & 70 & 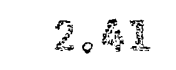 & 7.30 & .23 \\
\hline 20 & 䉂 & 15 & 121 & 20.04 & B. & 793.96 & .79 \\
\hline 意黑 & 6 & 32 & 3 & $5 \cdot 3$ & 20.70 & $3 \overline{4} \cdot 63$ & .20 \\
\hline 12 & 25 & 17\% & 286 & 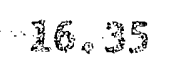 & .12 & 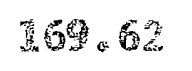 & .02 \\
\hline 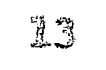 & 5 & $2 \xi$ & 29 & 2.55 & 2.35 & 26.8 & .23 \\
\hline 2 & 费 & 焉星 & 59 & 汿. & 220 & 32.59 & .02 \\
\hline 5 & 2 & 2 & 26 & 2.29 & $.0 \%$ & 23.72 & .00 \\
\hline 䈍鱼 & In & 4 & 51 & 娹心 & 6.76 & 46.52 & .65 \\
\hline $2 y$ & 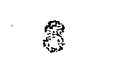 & 32 & 8 & 5.37 & 等 & 55.63 & $\cdot 12$ \\
\hline 笘㔠 & 0 & 29 & 29 & 205 & 2.55 & 26.5 & .25 \\
\hline 䈍䇾 & 䉕管 & 68 & 79 & 6.96 & 2,35 & $72.0 \%$ & .23 \\
\hline 25 & s & 12 & 13 & 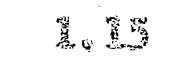 & .02 & 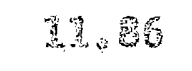 & .00 \\
\hline 22 & 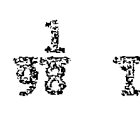 & $\frac{29}{62}$ & $22^{22}$ & 1. & 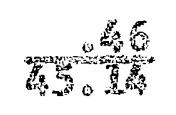 & 20.06 & $\frac{D^{2}}{w^{2}}$ \\
\hline 5 & Les & : & $\begin{array}{l}3 \% \\
3 \% \\
2 \%\end{array}$ & 37.57 & & \multicolumn{2}{|c|}{ 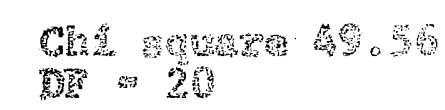 } \\
\hline
\end{tabular}


$10 \%$

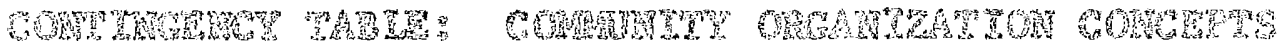

\begin{tabular}{|c|c|c|c|c|c|c|c|}
\hline & to & whe & Sul & Pas & 2 & 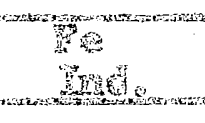 & 2 \\
\hline P & 2 & 32 & 33 & 2.96 & 0.35 & 30.2 & 03 \\
\hline$z$ & 0 & 38 & 39 & 3.52 & 3.5 & $35 \%$ & .35 \\
\hline 3 & 3 & A & 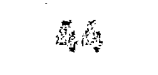 & 3.98 & .24 & 40.02 & .02 \\
\hline 䓵 & 3 & 62 & $g$ & 6.86 & 89 & 60.95 & .02 \\
\hline 5 & 9 & 25 & 132 & 2 幕。9 & .72 & Men & $.0 \%$ \\
\hline 6 & 3 & 23 & 3 & 3.07 & of & 30.93 & . \\
\hline 7 & I & 2 & 皿 & 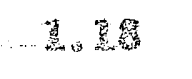 & .63 & Hess & .00 \\
\hline 2 & 9 & 65 & $y t_{s}$ & 6.68 & .80 & 5.35 & .09 \\
\hline$g$ & 3 & 25 & 28 & 2.33 & .09 & 250 & . \\
\hline 䈍 & 6 & 82 & 鳌品 & 8.30 & .78 & 95.53 & $a$ \\
\hline 䇛 & 鸽 & 9 & 98 & 8,58 & .95 & 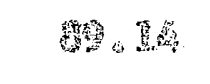 & .01 \\
\hline 12 & Be & 170 & 188 & 1609 & ob & 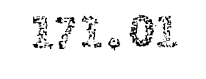 & $.0 \%$ \\
\hline 83 & 28 & 190 & 928 & 57.89 & .00 & 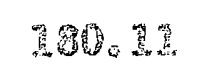 & .00 \\
\hline $\mathrm{s}$ & s & 68 & 72 & 60 & .99 & 65.58 & 10 \\
\hline 3 & 3 & 48 & 58 & 40 & .58 & 6030 & .06 \\
\hline 26 & 等算 & $50 \%$ & 212 & 10.2 & .09 & 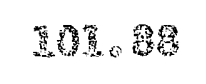 & $.0 \%$ \\
\hline 3 & 7 & 32 & 49 & 4.93 & 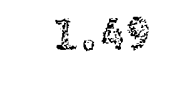 & 46,5 & 0 \\
\hline 28 & 19 & 73 & 88 & 7.95 & 6.25 & 90.09 & $6_{2}^{2}$ \\
\hline 19 & 20 & 62 & 72 & 6.31 & 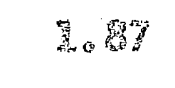 & 65.46 & 䴗 \\
\hline 28 & 等 & 20 & 22 & I. 90 & . & 96 & $.0 \%$ \\
\hline $2 \mathrm{R}^{2}$ & 高 & r & 童 & e 6 & $\frac{6}{28}$ & 9.9 & $\frac{00}{200}$ \\
\hline \multicolumn{6}{|c|}{ 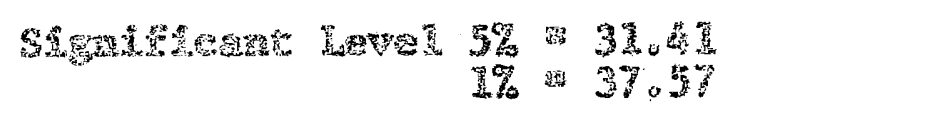 } & \multicolumn{2}{|c|}{ 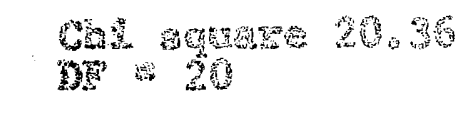 } \\
\hline
\end{tabular}


60WR2

\begin{tabular}{|c|c|c|c|c|c|c|c|}
\hline & gron & $F^{2}$ & 30 & 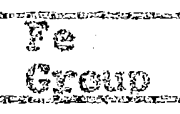 & $x^{2}$ & Po & $y^{2}$ \\
\hline 笘 & 2 & 93 & 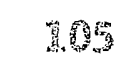 & 20.01 & 60 & 93.00 & $.9 x^{2}$ \\
\hline 2 & 2 & 73 & 75 & $7_{6} \times 5$ & 307 & 57.95 & .3 \\
\hline 9 & 2 & 73 & 75 & 70.5 & 2.7 & 62.65 & .39 \\
\hline s & 4 & 籍 & 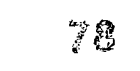 & 7 o & Hog & 79.57 &. \\
\hline 9 & 21 & 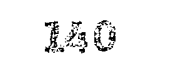 & 56 & 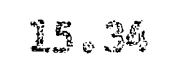 & 2.3 & 50606 & .28 \\
\hline 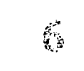 & 6 & 35 & 蚂素 & 309 & 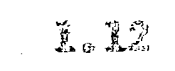 & 32.20 & 0 \\
\hline$y$ & 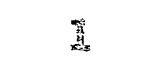 & 9 & 30 & .95 & .26 & a d o & .02 \\
\hline 9 & 95 & 94 & $\mathrm{~S}^{2}$ & In: 06 & 5.70 & 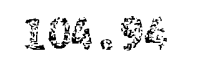 & .60 \\
\hline 9 & I & 22 & 23 & 203 & .65 & 20.9 & $.0 \%$ \\
\hline 熹制 & 25 & 289 & 262 & $2 \mu_{0} 97$ & 5.7 .7 & 237.9 & .60 \\
\hline 筶堂 & 管 & 72 & 83 & 3.95 & I. 21 & 75.09 & .23 \\
\hline 唯 & 2 & 24 & 26 & 25.55 & .10 & 32,206 & .01 \\
\hline 13 & 5 & 43 & 5 & 5.53 & 26.28 & 58.5 & 点。篦 \\
\hline 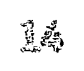 & 20 & 337 & 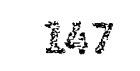 & 25.01 & 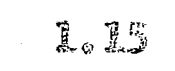 & 32,36 & 2 \\
\hline 营踢 & 3 & 51 & 59 & 5.5 & .90 & 49.95 & .00 \\
\hline $\mathrm{M}$ & 10 & 822 & 132 & 12.58 & 03 & 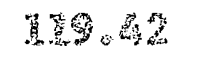 & .66 \\
\hline 䈍 & 7 & 60 & 73 & 6.96 & 02 & 60.97 & .00 \\
\hline If & s & 92 & 96 & 50.5 & $2,3 y$ & 56.95 & 027 \\
\hline 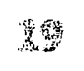 & 䈍惠 & 92 & 106 & 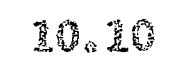 & 2.5 & 55.90 & .26 \\
\hline 28 & 2 & 27 & 25 & 2.76 & .21 & $26.2 \%$ & .02 \\
\hline 28 & $\frac{0}{210}$ & $\frac{72}{32}$ & $\frac{12}{20 \%}$ & 薏。悬 & Whosi & 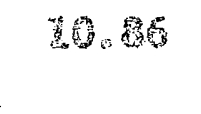 & 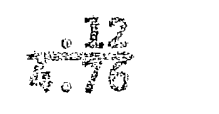 \\
\hline \multicolumn{6}{|c|}{ 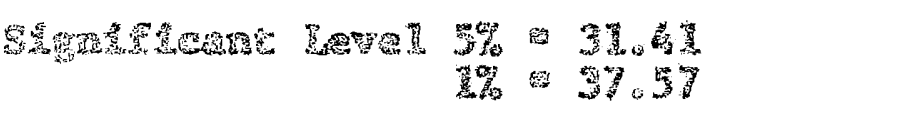 } & \multicolumn{2}{|c|}{ prom 20} \\
\hline
\end{tabular}


CONW

\begin{tabular}{|c|c|c|c|c|c|c|c|}
\hline & rover & $\frac{5}{530}$ & 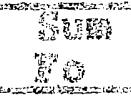 & 8 & $\mathrm{x}^{2}$ & 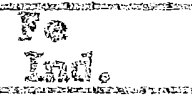 & $x^{2}$ \\
\hline 2 & 24 & (2) & 200 & 19.93 & .25 & $12 \%$ & 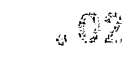 \\
\hline 2 & 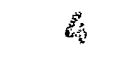 & 245 & 19 & 23,75 & 6 & 30 & .70 \\
\hline 3 & 6 & (5698 & 175 & 16.99 & 6.33 & Ispog & 0 \\
\hline 急 & 15 & 199 & 25 & 15.68 & 2021 & $39 \cdot 32$ & a. \\
\hline 3 & 36 & 35 & $39 \%$ & 35.58 & .01 & 332.00 & .00 \\
\hline 6 & 10 & $9 \%$ & 100 & 936 & .02 & 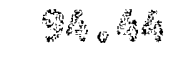 & aO \\
\hline 7 & 2 & 32 & 3 & 3,13 & 象焉 & 30,06 & .00 \\
\hline$g$ & 37 & 289 & 226 & 20.79 & 12.66 & 205.22 & 2.28 \\
\hline 9 & 6 & 53 & 5 & 5.42 & .96 & 33058 & . 0012 \\
\hline 20 & 20 & 450 & 870 & 43.22 & 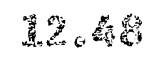 & 426,70 & 营。2 \\
\hline 1 & 25 & $19 \%$ & 28 & 20.9 & 3.28 & 2926 & 42 \\
\hline Ds & $5 \%$ & 585 & 62 & 59.5 & .07 & $582.9 \%$ & .02 \\
\hline 5 & 38 & 24 & 285 & 26.28 & 5.35 & 28079 & e \\
\hline 绐 & 跣 & 259 & 277 & 25.47 & 2. 2.5 & 2505 & 28 \\
\hline 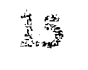 & 8 & 223 & 231 & 22.05 & 1. & 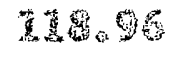 & 0.2 \\
\hline 16 & 31 & $26{ }^{3}$ & 293 & 27.3 & .35 & 261.916 & $\cdot 6$ \\
\hline 惫照 & 2 & 䈍意 & I83 & 16.33 & 2.598 & 籍 & 0 \\
\hline 笰繁 & 29 & 18 & 219 & 29.39 & 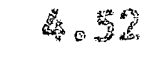 & 恚9. & 06 \\
\hline 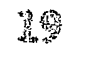 & 35 & 222 & 237 & 23.63 & $3_{0} E^{4}$ & 23503 & 0,5 \\
\hline 20 & 筑 & 59 & 63 & 309 & 5 & 3502 & 0 \\
\hline 2.5 & $\frac{2}{3}$ & $\frac{G}{46 \%}$ & $\begin{array}{r}43 \\
653\end{array}$ & 302 & bover & 39.05 & 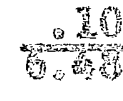 \\
\hline
\end{tabular}

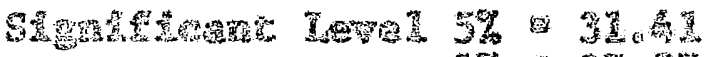

